\begin{abstract}
UNIVERSIDADE DE SÃo PAULO
Faculdade de Filosofia, LeTras E CiênCIAS Humanas DEPARTAMENTO DE GEOGRAFIA

Programa de Pós-Graduação em Geografia Humana
\end{abstract}

FILIPE GIUSEPPE DAL BO RIBEIRO

\title{
A Geografia Militar no Brasil: A QUESTÃo dA DEFESA NACIONAL.
}




\author{
UNIVERSIDADE DE SÃo PAULO \\ FACULDADE DE FILOSOFIA, LETRAS E CIÊNCIAS HuMANAS \\ DEPARTAMENTO DE GEOGRAFIA \\ Programa de Pós-Graduação em Geografia Humana
}

\title{
A Geografia MiLitaR no Brasil: A QUESTÃo dA DEFESA NACIONAL
}

FILIPE GIUSEPPE DAL Bo RIBEIRO

Tese de doutoramento apresentada ao Programa de Pós-Graduação em Geografia Humana, do Departamento de Geografia da Faculdade de Filosofia, Letras e Ciências Humanas da Universidade de São Paulo, para obtenção do título de Doutorado em Geografia Humana.

Orientador: Professor Doutor André Roberto Martin 
A guerra é o inferno.

(William T. Sherman) 


\section{$\underline{\text { RESUMO }}$}

O presente trabalho apresenta as questões a cerca da Geografia Militar e da Questão da Defesa do território nacional, estabelecendo uma profunda relação entre elas. Sobre o primeiro conceito, a Geografia Militar, construímos uma linha teórica que apresenta a ideia de que a necessidade de se defender ou de atacar passa pela questão do espaço geográfico e da história. A Geografia Militar no Brasil pode ser analisada a partir dos antigos relatos e documentos sobre batalhas se estruturando uma pequena história da geografia militar no Brasil. A influência da política portuguesa e ibérica nas movimentações do território colonial é um verdadeiro vertedouro de pequenos debates envolvendo a geografia geral e a geografia do teatro de operações de Guerra. No século XIX, nasce a Geografia Militar como disciplina e mais tarde como campo de estudo das ciências militares, sendo amplamente modernizada pelo desenvolvimento da Geografia Geral. Depois da Guerra do Paraguai, a Geografia aparece no currículo dos cursos de formação dos oficiais brasileiros. No começo do século XX, Euclides da Cunha escreve "Os Sertões" e a geografia, a antropologia, estratégia e tática aparecem em muitos casos como centrais nas análises da Guerra de Canudos, se tornando a obra prima da Geografia Militar brasileira. No início do século XX, Paula Cidade traz a questão da Geografia Militar na discussão da modernização do exército nacional, mas a disciplina é preterida diante das questões Geopolíticas. Atualmente, diante da luta contra o imperialismo crescente, a questão da Geografia Militar se apresenta novamente.

\section{PALAVRAS-CHAVE:}

Geografia Militar, Defesa Nacional, Geopolítica, Logística e Inteligência 


\section{RESUME}

The current work shows questions about the military geography and the defense of the national territory, establishing a deep relationship among them. Concerning the first concept, the military geography, we built a theoretical line that depicts the idea that the need to defend or attack involves the question of geographical space and history. Military geography in Brazil can be analysed beginning with ancient descriptions and documents about battles structuring a small history of the military geography in Brazil. The influence of the portuguese and iberian politics in the colonial territory is a real source of small debates involving general geography and the geography of the war theater of operations. In the 19th century, the military geography becomes an academic subject and later on a study field for military sciences, being widely modernized by the development of general geography. After the Paraguay war, geography becomes part of the study program for the brazilian officer graduation. Early in the twentieth century, Euclides da Cunha writes "Rebellion in the Backlands (Os Sertões) and geography, anthropology, strategy and tactics get an outstanding importance in the analyses of the "Canudos War" (Guerra de Canudos), becoming the "masterpiece" of the brazilian military geography. Early in the twentieth century, Paula Cidade brings the military geography to the discussion of the modernization of the National Army, but this subject is left aside because of geopolitical questions. Nowadays, due to the fight against the growing imperialism, questions involving the military geography rise again.

\section{KEY-WORDS:}

Military Geography, National Defense, Geopolitics, Logistics, Intelligence. 
Índice

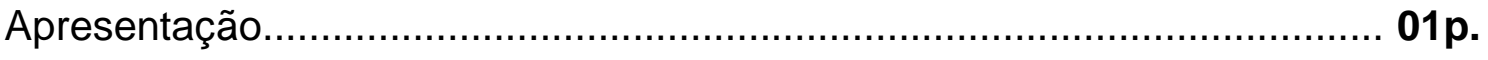

Introdução Metodológica..................................................................11p.

Primeira Parte 1 -

Raízes da Geografia Militar: uma abordagem geohistórica.........................50p.

CAPÍTULO 1 - Nas Trilhas da Geografia Militar no Brasil: A Formação dos Estados Ibéricos e "As Grandes Navegações".

$51 \mathrm{p}$.

CAPÍTULO 2 - A União Ibérica e o "Destino Manisfesto" Luso-Brasileiro na América do Sul: o Alvorecer da Geografia Militar no Brasil... $.72 p$.

CAPÍTULO 3 - A Guerra contra os Holandeses e Bases da Formação Nacional: Guerra de Guerrilha, Defesa Estratégica, Resistência. 100p.

\section{Segunda Parte 2 -}

A Geografia Militar: por uma busca do autoconhecimento......................139p.

CAPÍTULO 4 - A Formação do Estado Nacional, o Nascimento das Instituições Militares e a Geografia Militar no Brasil na Aurora do "Longo" Século XIX..140p.

CAPÍTULO 5 - Guerra do Paraguai, Geografia Militar e Nacionalismo: Defesa, Cartografia e Logística. $171 \mathrm{p}$.

CAPÍTULO 6 - O Fim do Longo Século XIX, a Geografia Militar Brasileira se Apresenta: "Os Sertões" de Euclides da Cunha. .210p.

CAPÍTULO 7 - GAL. Paula Cidade: a "sua" Geografia Militar e seu "Esquecimento". 220p.

ANEXO 1 - PRIMEIRA BATALHA DOS GUARARAPES (1648). $.260 p$.

ANEXO 2 - A SEGUNDA BATALHA DE GUARARAPES (1649). $.261 \mathrm{p}$. ANEXO 3 - DESCRIÇÃO DA SEGUNDA BATALHA DE GUARARAPES...262p. 


\section{I- Apresentação}

A Geografia Militar era uma das especialidades práticas da Geografia, juntamente com a Geografia Médica e a Geografia Comercial, até o surgimento do revolucionário "determinismo" de Friedrich Ratzel. Com sua Geografia Política (1898), ele ampliou de tal modo o escopo da Geografia Militar que esta se viu reduzida a mera técnica, no entanto, de emprego universal. Os temas estratégicos, embora pouco frequentes na pesquisa geográfica brasileira, ultimamente, são cada vez mais comuns em outras áreas do conhecimento, notadamente entre economistas, administradores e cientistas políticos.

Em uma primeira pesquisa (dissertação de mestrado) intitulada "A Nova Geografia Militar: Logística, Estratégia e Inteligência", orientada pelo Professor Livre Docente Dr. André R. Martin, e defendida no Departamento de Geografia da Faculdade de Filosofia, Letras e Ciências Humanas no primeiro semestre de 2010, foi organizado um levantamento bibliográfico sobre o tema até então inédito na geografia acadêmica brasileira. O trabalho foi apoiado no resgate da experiência esquecida da geografia militar estadunidense, que, segundo COLLINS (1998), somente começou a ser discutida no $92^{\circ}$ encontro anual da Associação de Geógrafos Americanos, em 1996, após grande discussão para então se criar um grupo de estudo especialmente tratando do assunto.

O presente trabalho visa resgatar a experiência esquecida da geografia militar no Brasil, no que ela contribuiu para a formação territorial do país e para o patrimônio cultural da nação. Por outro lado, pretende-se interrogar, também, até que ponto as necessidades "modernas" de defesa, que incluem inescapavelmente a constituição de um parque industrial bélico, acomodaram-se ou opuseram-se àquela herança logística que vinha se constituindo desde a Colônia e o Império. Nesse sentido, esta tese de doutoramento configura-se como uma pesquisa de Geopolítica com ênfase na sua aplicação prática em termos de políticas territoriais. 
No meio científico, nos debates acadêmicos, encontros de geógrafos, dissertações e teses o tema da Geografia Militar ainda é pouco apreciado. A ciência geográfica brasileira não tem dado relevância a esse segmento. Mesmo não sendo um assunto recente, seu estudo foi quase totalmente esquecido nas últimas décadas. $O$ resgate deste tema ocorreu na realização, em 2010, da pesquisa citada anteriormente e comentada pela Agência de Notícias da USP, em 18/08/2010, por Júlio Bernardes, num artigo intitulado "Aplicações da geografia militar voltam a ser debatidas":

A geografia militar, adotada no conhecimento territorial de áreas de guerra, começa a ser resgatada pelos meios acadêmicos. Na Faculdade de Filosofia, Letras e Ciências (FFLCH) da USP, o geógrafo Filipe Giuseppe Dal Bó Ribeiro pesquisou a trajetória da geografia militar desde o século 19.

O título da presente tese, "A Geografia Militar no Brasil e a Questão da Defesa do Território Nacional", levanta dois aspectos que são fundamentais para o aprofundamento do tema: primeiro, não estaremos nos limitando apenas à geografia militar brasileira, e sim, em pensar sobre o desenvolvimento e emprego da técnica no Brasil. Isso traz para o estudo um caráter mais amplo, pois a Geografia Militar, embora seja carregada do sentimento nacionalista, em si mesma não exprime tal conotação. As impressões de relatos estrangeiros podem criar um quadro de debates sobre como agir em determinada conjuntura geográfica; alguns problemas ainda permanecem, em muitos sentidos, ainda nos dias de hoje; já a segunda parte do trabalho levanta a hipótese de que a geografia militar no Brasil surge em função de uma necessidade de defesa do território nacional e, portanto, aqui a abordagem se difere completamente da geografia militar estadunidense, que tem um caráter mais ofensivo. Mesmo no momento da expansão territorial, as expansões luso-brasileiras buscaram um heartland, área continental que não possuí acesso pelo mar. Assim, desta forma, não ficando preso aos desígnios do mar, essa retaguarda territorial foi ao mesmo tempo um fator de defesa importante, tanto para o mar quanto para as povoações andinas, núcleo duro

\footnotetext{
1 In: (http://www4.usp.br/index.php/sociedade/19609-aplicacoes-da-geografia-militar-voltam-aser-debatidas).
} 
da administração colonial do império espanhol. A questão central é: até que ponto o conhecimento da geografia foi importante para o Brasil na busca da integridade territorial?

O presente estudo pretende abarcar os muitos aspectos que envolvem a formação militar brasileira e o conhecimento do território nacional, isto é, o desenvolvimento do saber geográfico no Brasil fora dos meios acadêmicos civis. Não nos limitando a estudar a geografia militar apenas como disciplina nas instituições militares, mas faremos a análise desta como ciência aplicada.

Assim, o viés da Geografia Militar nos permite alcançar uma abrangência maior de reflexões e não se prende às tradicionais escolas, que fazem parte do arcabouço teórico-metodológico da geografia, o que a deixa, de certa forma, limitada. Portanto, o viés da Geografia Militar, por permitir esta abertura em termos conceituais, traz para o interior da ciência geográfica, enriquecendo o temário da geografia e, consequentemente, o presente trabalho abarca outros temas que não eram tão previsíveis, aprimora metodologicamente e epistemologicamente a ciência geográfica. Yves Lacoste tem sido um crítico desta limitação. Por que ele escreveu o seu grande best seller? Porque entendeu que a geografia se negou a fazer uma reflexão política sobre o espaço e se apequenou epistemologicamente.

Assim nosso objetivo é trazer para o aporte teóricometodológico da ciência geográfica a contribuição dos levantamentos geográficos feitos pelas ações militares ao longo de nossa história.

Como foi feita a seleção dos episódios? Sabemos que existem inúmeros fatos que foram importantes para a formação territorial do país. Não é fácil fazer um recorte, e ao mesmo tempo o trabalho não pretende trazer o específico, mas sim ampliar um campo de estudo. Acreditamos que no futuro próximo este trabalho poderá suscitar outros inúmeros trabalhos no campo da Geografia Militar.

$\mathrm{Na}$ primeira parte do trabalho, que trata do nosso passado colonial, a escolha pelas guerras holandesas e pela viagem de Capitão Pedro Teixeira pelo rio Amazonas nos trazem duas políticas diferentes no mesmo período e enriquece muito a discussão sobre expansão e defesa. Como a 
política filipina não tinha total controle da ação de algumas forças locais, que em alguns momentos se atiravam em interesses próprios ou em projetos mais portugueses do que espanhóis; torna-se fundamental distinguir nas ações militares quais os interesses em questão. No entanto, a guerra contra os holandeses foi um episódio central e o escolhemos não só porque temos o maior e mais acessível acervo sobre um episódio bélico colonial brasileiro, mas porque ele envolve direta e indiretamente outras potências colonialista. As forças de defesa ao longo da maior parte do período colonial foram formadas em função dos conflitos, na maior parte reunindo o corpo de guerra às pressas. Institucionalmente só podemos falar de uma força permanente em 1824, com a criação da marinha e do exército nacionais.

No nosso trabalho analisaremos a discussão das fronteiras e os conflitos que a envolveram, como a invasão de Caiena, feita por D. João VI (que enviou uma expedição militar comandada pelo Tenente-Coronel Manuel Marques para conquistar a Guiana Francesa que, além de escunas e bergantins, possuía cerca de 800 homens e escolta de uma corveta inglesa), além da Guerra do Paraguai (1864-70) e da Guerra de Canudos (1896-97). Também discutiremos a importância do Barão de Rio Branco para o debate de modernização do exército brasileiro.

Com isso, analisaremos uma série de clássicos buscando as contribuições do debate geográfico em Visconde de Taunay, em sua obra clássica "Retirada de Laguna", do Conde D'Eu, em "Viagem militar ao Rio Grande do Sul"; Duque de Caxias e suas missões pacificadoras, fundamentais para a unidade territorial nacional e entre outros. Vale sublinhar que todos esses grandes nomes estão marcados na história do século XIX, quando o Brasil estava consolidando suas fronteiras, ao mesmo tempo, que realizava 0 autoconhecimento de sua grandeza e diversidade geográficas. Ora, muito antes da geopolítica estar presente nas discussões sobre a defesa do território em instituições militares de ensino superior, a geografia militar já era discutida e praticada em toda a sua plenitude pelos oficiais e especialistas brasileiros.

Como o título se refere à Geografia Militar no Brasil, mas não se restringindo apenas a textos brasileiros, podemos expandir os estudos a teóricos militares de outros países que pensaram o Brasil. Tratando dos 
conflitos fronteiriços do início do século XIX na bacia do rio da Prata, no livro "Contribuições para História da Guerra entre Brasil e Buenos Aires" (1825-28), publicada em uma tipografia em Berlim (1834) e de forma anônima (obra na qual o autor se intitula "uma testemunha ocular") já se analisava a tendência brasileira ao pan-americanismo. Ao comentar a Batalha do Passo Rosário, na Guerra da Cisplatina, perdida pelo Brasil, o autor percebe a formação das fronteiras entre Brasil, Argentina e Uruguai calcada nos modelos do Estado Nação típico da civilização ocidental, além de uma postura conciliadora que será marcante na história do Brasil independente. Outra contribuição bem relevante foi a do grande crítico do Brasil na Guerra do Paraguai, o oficial prussiano Max Von Versen, preso no Rio de Janeiro por desejar assistir à guerra do lado de Lopes. Mesmo com muitas inverdades escritas sobre os brasileiros, o seu livro "História da Guerra do Paraguai" analisa a geografia do teatro de guerra e se torna uma contribuição interessante ainda por ser analisada pelo olhar de um geógrafo. Assim como o geógrafo inglês Richard Burton que fez excelentes contribuições sobre o estudo da Guerra do Paraguai.

O esquecimento da experiência da Geografia Militar como disciplina e como tema nos chama atenção de maneira significativa. Os tópicos que envolvem este assunto estão cada vez mais relegados a um segundo plano dentro das pesquisas em geografia. Os temas levantados pelos estudos de Geografia Militar estão relacionados à estratégia no geral. A retomada de estudos como este recoloca a Geografia como disciplina central, por ser esta uma ciência que envolve múltiplas disciplinas o que possibilita uma opinião geral sobre o fenômeno espacial.

Mais recentemente, os estudos de Geografia Política foram sendo retomados pela geografia acadêmica. A Geopolítica que era raramente discutida foi novamente debatida por MARTIN (2007) em sua tese para livre docência, na qual define o Brasil como a nação geopolítica. De acordo com MARTIN (2007), a geopolítica possui um caráter mais ideológico enquanto, a Geografia Militar é mais prática: das diferenças e relações entre Geografia Militar e Geopolítica, encontramos sua comparação com estratégia e tática; e como elas podem complementar uma a outra criando pontes entre a teoria e a práxis.. 
Portanto, o resgate dos estudos da Geografia Militar é absolutamente coerente com o resgate da Geopolítica pela Geografia. Uma discussão mais crítica do tema, buscando desvendá-lo, entendê-lo e dissecálo, orientaria o estudo e seu caráter doutrinário. Ademais, tal assunto não pode estar alheio aos debates que fazem parte de nosso arcabouço teóricometodológico.

A distinção feita entre as especificações ou sub-áreas da Geografia como Geoestratégia, Geopolítica e Geografia Militar podem ser realizadas, a princípio, pela escala de análise. A Geopolítica pode ser encarada de formas diversas, como arte, como ciência, como ramo apenas da Geografia, como perspectivas de uma estratégia global de nações. A Geoestratégia integra, por sua vez, a Geopolítica, ponderando-a e condicionando-a. Já a Geografia Militar pressupõe a utilização dos conhecimentos dos fatores geográficos (ver tabela 1) a favor das Forças Armadas de uma determinada nação.

Tabela 1- Fatores Geográficos

\begin{tabular}{|l|l|}
\hline Aspectos Físicos & Aspectos Culturais \\
\hline Relação Espacial & Raízes étnicas e raciais \\
\hline Topografia e Drenagem & Padrão populacional \\
\hline Geologia e Solos & Estrutura Social \\
\hline Vegetação & Linguagens e Religiões \\
\hline Oceanos e Mares & Indústria e uso da terra \\
\hline Duração do dia e da noite & Rede de Transporte \\
\hline & Telecomunicações \\
\hline & Instalações Militares \\
\hline
\end{tabular}

Organizado por Filipe Giuseppe Dal Bo Ribeiro (2015) 
O suporte empírico de nossa demonstração começa pela história do pensamento geográfico, importante necessidade para localização do estudo da Geografia Militar no Brasil e também o estudo da sociologia do conhecimento, distinguindo os principais atores e autores, instituições e teorias sobre a construção da Geografia Militar no Brasil.

A Geografia Militar surgiu como um ramo da Geografia Geral, que estuda os fatores geográficos humanos, físicos, econômicos, políticos e militares e suas relações espaciais correspondentes ao cenário de conflito, interpretando-os para deduzir a influência que tais fatores exercem na condição militar. Mas esta disciplina é tão antiga quanto a própria guerra e, certamente, mais antiga que a ciência geográfica universitária que, segundo LACOSTE (2008), é datada do século XIX. Portanto, podemos depreender que esta surgiu para apoiar ainda mais os impérios europeus em sua expansão e, a partir de então, dar às conquistas um caráter mais cientificista. A Geografia Militar se orienta, sobretudo, para aproveitar as vantagens e avaliar os inconvenientes que os fatores geográficos representam no cerne social da guerra, contribuindo como base fundamental para a organização das forças armadas e da defesa dos Estados Modernos (Territoriais).

Philipe BOULANGER (2002) nos chama a atenção para o fato de que a ciência geográfica começa a ser estudada pelas escolas de oficiais do exército francês no início do século XIX e estes logo utilizarão os seus conhecimentos recém adquiridos na aplicação de técnicas e estratégias militares. Na primeira metade do século XIX, a disciplina Geografia Militar começa a ser ensinada na formação da elite militar francesa na Escola Especial de Sain-Cyr pelo professor Théophile Lavallée. Este professor organiza os primeiros fundamentos da disciplina em seu livro Geógraphie physique, historique et militaire, publicado em 1832.

No caso da geografia militar no Brasil temos que ter cuidado com dois aspectos históricos importantes.

A Geografia Militar surge no Brasil, como disciplina, após a I Grande Guerra Mundial. Segundo o Major Engenheiro Ary Pelegrino Filho, o governo brasileiro resolveu contratar uma missão estrangeira para instruir o Exército Nacional. Então, em 1919, foi contratada a Missão Militar Francesa 
(MMF), que atuou nas escolas militares até 1940. A influência da escola de pensamento militar da França aperfeiçoou a instrução e organização da Escola de Comando e Estado Maior do Exército (ECEME), conhecida na época como Escola do Estado Maior. A MMF introduziu temas de História e Geografia Militar por fazer parte da modernização do ensino militar, visto que estas disciplinas serviam como fonte de inspiração e ensinamento que, quando desprezadas, poderiam significar uma iminente derrota em uma guerra.

[...] ensinou-nos a ler, entender e interpretar
ensinamentos militares expostos nos livros dos
mestres e dosá-los de acordo com o escalão
considerado; proporcionou grande impulso à
bibliografia militar brasileira, difundindo uma doutrina
de guerra em publicações que incluíam História,
Geografia, organização militar, técnica operativa etc.
(Marechal J. B. Matos, 1968, p.57 apud Major
PELLEGRINO FILHO, 2002)

Em segundo lugar, é plausível considerar que, se a Geografia Militar é uma prática ou a Geografia Aplicada, ela é anterior ao seu surgimento como disciplina. Como o século XIX é o momento em que o Brasil se eleva à condição de nação, surge uma primeira demanda pelo desenvolvimento deste conhecimento, desde o momento que somos elevados a condição de Reino Unido de Portugal-Brasil-Algarves, passando pela Guerra do Paraguai, e, mais tarde, pelas revoltas internas, mais tarde durante a Guerra dos Canudos, Farropilhas, Contestado, entre outras.

Portanto, em nossa pesquisa, o aporte historiográfico é crucial para se analisar quais foram as contribuições reais para o conhecimento de nosso território e as figuras que pensaram a geografia do Brasil a partir dos levantamentos militares que poderiam ser feitos nestes eventos bélicos. Vale indagar até que ponto, o conhecimento geográfico foi importante para defesa do território e, por fim, de sua integridade territorial.

Outra questão relaciona-se a periodização do trabalho. Por que um tempo tão longo? É um espaço temporal muito extenso. Entretanto, o nosso objetivo geral é mais ampliar este campo de pesquisa, trazendo para os futuros pesquisadores apontamentos possíveis de se tornarem futuros estudos no campo da Geografia Militar. Este não é um problema exclusivo da Geografia, 
mas de qualquer pesquisa apoiada numa perspectiva histórica. Por onde começar? Quando podemos dizer que temos uma Geografia Militar no Brasil?

De forma análoga, em outro campo das ciências humanas, na área de literatura brasileira, este fora o debate travado entre Afrânio Coutinho, Antônio Cândido e Haroldo de Campos. Estes autores tinham opiniões divergentes sobre a questão de quando podemos dizer que a literatura brasileira surge efetivamente. Como vemos, não é um debate exclusivo da Geografia.

Este questionamento abre dois caminhos que poderiam ser seguidos para realização desta pesquisa: o primeiro é aquele que diz que a literatura brasileira surge quando aparece um engajamento ligado à construção de um sentimento nacional no século XIX, uma literatura engajada capaz de criar um público e uma escola estilística, esta tese é defendida por Antônio Cândido; e outro que afirma que o engajamento da literatura do século XIX, não é o único sentimento a definir a literatura de um lugar, o sentimento contrastante entre o mundo cristão europeu e a terra a ser conquistada, "a brasilidade já se vinha constituindo, consolidando e libertando havia muito antes da fase de 1750 a 1836". (COUTINHO, 1981 apud CORREA, 2009) Escolher um período histórico longo é uma tarefa árdua, entretanto necessário para os propósitos deste trabalho.

Portanto, segundo Coutinho, o sentimento do ideal nacional
de se libertar do poder de Portugal que existia desde os
primeiros tempos, fez com que os brasileiros buscassem
modelos fora de Portugal, encontrando no Barroco espanhol
uma forma de reagir contra o jugo português. Dessa forma,
Coutinho atribui ao Barroco brasileiro uma preocupação
nativista. (CORREA, 2009)

Assim, o trabalho foi estruturado em duas grandes seções: a primeira que busca as raízes da Geografia Militar no Brasil e a segunda, que irá atentar para o desenvolvimento da Geografia Militar brasileira ao longo do tempo. Então a pergunta que poderíamos fazer é, porque recuar para a fase colonial ao invés de partir diretamente para o estudo Geografia Militar brasileira? Por que ir até o século XVI para buscar essas raízes? Pois nesse período é que encontramos as bases da formação territorial do Brasil, conforme aponta Robert Moraes (2000). Segundo esse autor, o território colonial 
brasileiro se formará no "longo" século XVI e de lá pra cá as alterações territoriais que tivemos foram pequenas. Outra pergunta poderia ser feita com relação aos períodos abordados pela pesquisa: "por que ir até a Idade Média para buscar as trilhas da Geografia Militar no Brasil?" Em "Raízes do Brasil", o Professor Sérgio Buarque de Holanda aponta que na construção de nossa identidade é muito difícil desvencilhar o passado da construção política da Península lbérica.

\begin{abstract}
Nem o contato e a mistura com raças indígenas ou adventícias fizeram-nos tão diferentes de nossos avós alémmar como às vezes gostaríamos de sê-lo. No caso brasileiro, a verdade, por menos sedutora que possa parecer a alguns dos nossos patriotas, é que ainda nos associa a Península Ibérica, a Portugal especialmente, uma tradição longa e viva, bastante viva para nutrir, até hoje, uma alma comum, a despeito de tudo quanto nos separa. Podemos dizer que de lá veio a forma atual de nossa cultura" (HOLANDA, 2006: 40).
\end{abstract}

Ainda de acordo com a ideia de que as bases de formação territorial e nacional estão na formação do Estado Nacional Português e na instalação de um projeto de colonização, FREIXINHO (1994:18) afirma que:

As terras americanas do Atlântico Sul, de objetivo inicial estratégico complementar da política ultramarina de Lisboa, converteram-se, a partir de um dado momento, no eixo dominante e da estratégia mundial de Lisboa. Aqui, nos séculos XVI-XVIII, passa a ser o ponto de aplicação prioritário e de concentração de poder e do potencial do Estado Nacional Português. Assim nasce e se desenvolve o Estado do Brasil como País-Colônia Luso-Brasileiro, de dimensões continentais e de expressivo potencial econômico.

Desse modo, os sucessivos governos portugueses na América Meridional em trezentos anos conseguiram uma dominação em todos os campos de poder: na posse e ocupação litorânea contra qualquer intromissão estrangeira; no monopólio colonial em benefício da Metrópole; nos aparatos militares de defesa e nas instituições jurídico-administrativas, o que assegurou o domínio e o controle centralizados sobre toda a Colônia. A partir desse espaço político-administrativo original deu-se 0 alargamento das fronteiras além Tordesilhas (1494). Os portugueses expandiram seu território para as 
regiões geográficas das Bacias do Amazonas e Prata, tendo, evocado por Alexandre de Gusmão, o termo do direito romano uti possidetis, que significa "a posse pelo uso da terra", o qual ou "o reconhecimento da posse cível", colocou praticamente um ponto final nos ajustes territoriais pós União lbérica.

Atualmente, as discussões sobre o tema estão encaminhadas segundo a ótica da segurança. Ao se analisar o Plano de Defesa Nacional (2008), percebe-se que o Brasil se prontificou a atender as resoluções das Nações Unidas ao aplicar o conceito de Segurança Internacional. Segundo CEPIK (2001), os fatores que determinam a segurança do indivíduo são muito mais complexos do que os argumentos realistas de segurança nacional. Portanto, o conceito de segurança nacional cai em desuso e entra a noção do conceito defesa regional, ou seja, conselhos de segurança multiestatais, que começam a ser estruturados. Há uma transformação do caráter das forças armadas, que começam a atuar com um sentido mais policialesco e em missões pacificadoras, ao invés de atuar como um defensor das fronteiras nacionais.

No caso do Plano de Defesa Nacional, é declarado que não existem ameaças externas e, segundo CEPIK (2001), a função primária do conceito de human securty tem sido menos a de estruturar um programa de pesquisas e mais a de orientar a política externa de alguns países. Com isso, a ideia de nos constituirmos num soft power cresce em detrimento de delimitarmos realmente um plano que articule a integração territorial e ações de defesa rápida nas áreas de fronteiras.

\section{II- Introdução Metodológica}

\section{1- Geografia Militar, questões metodológicas}

Dois aspectos são fundamentais para percebermos 0 valor dos elementos geográficos na guerra: primeiro, o conhecimento dos fenômenos geográficos, tanto físicos como descritivos; segundo, a capacidade interpretativa para poder avaliar e interpretar a influência que teria nas operações militares que se projetam, permitindo, com isto, aproveitar, elucidar e vencer usando os aspectos geográficos. É desta capacidade interpretativa 
que se ocupa a Geografia Militar. Seria um enorme erro considerar que os fatores geográficos significam tudo numa guerra, mas estes possuem uma grande influência, mas subestimá-los, relegando-os a um segundo plano, também configura-se em equívoco.

A presença de alguma interação entre as condições geográficas e os assuntos militares é o escopo da Geografia Militar. Segundo PELTIER \& PEARCY - em Military Geography, um manual sobre a Geografia Militar, publicado em Princeton (1966) - as pesquisas sobre o assunto se dividem em três grandes categorias: sistemática, geral e regional. A primeira categoria, a sistemática, direciona a aplicação da ciência aplicada para conduzir os assuntos militares. Já os amplos assuntos da Geografia como a geomorfologia, a hidrografia, a biogeografia, e a geografia política, envolvem a adaptação do soldado ao meio são exemplos da geografia geral. A Geografia Militar regional atua como síntese, trazendo vários aspectos da geografia e como eles devem ser aplicados a uma região militar particular. Embora todas estas considerações estejam presentes em comentários e estudos clássicos, esta sistematização só foi possível no século XIX e XX, quando se desenvolve o ramo da fotografia, aerofotogrametria e a cartografia, então observamos um ritmo intenso em áreas mapeadas e um elevado grau de detalhe desse mapeamento.

A ciência geográfica compreende um amplo espectro de ação, abarcando conhecimentos específicos que vão desde entender nosso planeta no seu cosmo (o estudo da natureza e a constituição da Terra) até observar a conduta do homem sobre a superfície terrestre. De maneira resumida, o caráter dual desta ciência (estudar os aspectos físico e humano) possibilita articular os níveis de relação entre o meio e a sociedade e como estes se interagem. $O$ meio pode ora ser um fator de barreira a determinadas manobras, ora pode ser superado através de uma tecnologia. Tanto no planejamento territorial quanto numa guerra as condições geográficas puderam ser superadas com advento da engenharia. Mas o conhecimento geográfico é fundamental para prever as dificuldades e orientar a logística dos exércitos.

A Geografia Militar não é uma ciência separada da Geografia Geral. Ela foi muitas vezes classificada pela comunidade geográfica como 
geografia aplicada, como faz, por exemplo, PELTIER \& PEARCY (1966). "No décimo nono Congresso Internacional de Geografia em Stockolm (1960) e no vigésimo Congresso Internacional de Geografia em Londres (1964) um novo ramo da geografia, chamado "Geografia Aplicada", surgiu como distinto da geografia econômica"² (ibidem, 1966:19). Com a ideia de planejamento territorial, que veio a ser uma das características essenciais dos Estados planificados, o termo geografia aplicada passa a ter outra conotação. Os conhecimentos da geografia passariam a ter a partir de então novas utilizações.

Se a geoestratégia é o outro nome que se dá à Geopolítica (MARTIN, 2007), a geografia estratégica é outro nome que se dá para Geografia Militar. Segundo PELTIER \& PEARCY (1966), a geografia estratégica se encaminha para o plano da geografia da guerra, plano da campanha da guerra e o plano operacional da guerra. Entretanto, a geografia estratégica também deve envolver o desenvolvimento de modelos realistas e padrões de treinamento. Dos cinco elementos da estratégia expressados por Clausewitz, a geografia estratégica está associada com a geometria das operações, com o meio da área de operações e os apoios dos meios e fontes de recursos. Uma vez que a geografia estratégica é a geografia dos planos, e isto deve ser um prognóstico dos estudos de procedimentos, como uma prévia do que se pode imaginar sobre as atividades militares sobre condições específicas. Este conjunto de condições especiais provê um elemento de motivação pelo qual se desenvolvem os aspectos dinâmicos da geografia. Isto também provê uma fonte de relações e estudos dos impactos das ações militares, seus custos e sua eficiência. Portanto, esse conceito abarca inescapavelmente sobre o conceito de Práxis.

Marx define a Praxis como atividade prático-crítica, isto é, como atividade humana perceptível em que se resolve o real concebido subjetivamente (...). O materialismo histórico de Marx estabelece entre os dois elementos uma relação prática, uma relação ativa. A natureza não existe por si, mas

\footnotetext{
2 PELTIER \& PEARCY. Military Geography. At the Nineteenth Internacional Geographical Congress in Stockholm (1960) and Twentieth Internacional Geographical in London (1964), a new branch of geography called 'applied geography' emerged distinct from econmic geography". (p.19)
} 
só em relação ao homem; por isso, se pode dizer, (...), que ela é o nosso passado, pois constitui o acúmulo das atividades dos séculos passados. A natureza só tem sentido para o homem na medida em que foi por ele modificada, na medida em que suportou os fins que the foram impostos para satisfação de necessidades reais. (BOBBIO et all, 1998: 987-988).

Os princípios da geografia estratégica envolvem a interpretação de informações básicas para o uso na preparação de planos para conduzir a guerra, ou para as operações durante a guerra. Dentro deste contexto as grandes considerações da geografia estratégica devem ser descritas em seis elementos: acessibilidade, mobilidade, visibilidade, comunicabilidade, disponibilidade e vulnerabilidade. Segundo PELTIER \& PEARCY (1966), esses elementos inclinam-se para centralização do fator da acessibilidade num sentido amplo do mundo. Mais especificamente, relacionam a interação entre as forças ou componentes e ajudam a definir melhor as formas de contato: se esse contato pode ser visual, eletrônico ou direto; definição dos tipos de armas que serão usadas, entre outros.

Os exércitos da era pré-elétrica operavam em um horizonte de inteligência consideravelmente menor que 160 quilômetros. Daí a enorme importância atribuída pelos comandantes do passado à informação estratégica; o tipo de inimigo, o tamanho e a capacidade de suas forças, sua disposição, a natureza do terreno em sua zona de atividade e, mais geralmente, os recursos humanos e naturais dos quais dependia sua organização. (KEEGAN, 2006:37).

A acessibilidade, o primeiro dos seis elementos da geografia estratégica, visa compreender as variantes do espaço físico nas ações militares e também elementos como condições das construções, organização espacial da população, tipos de estradas, rotas, distâncias. Entretanto, a acessibilidade se difere para o uso de carros de combate (automóveis), aviões e barcos. Os aviões possuem uma velocidade elevada, mas precisam de uma pista de pouso. A acessibilidade da pista de pouso é bem diferente da acessibilidade da área de manobra entre dois aeroportos e entre a área de ação que possuem uma dependência, por sua vez, do tempo atmosférico. Os automóveis, caminhões, carros de combates viajam bem em áreas limpas, planas e 
superfícies planas, mas não são eficientes em áreas de pantanosas e florestas. Os navios são importantes componentes, pois carregam consigo aviões, caminhões, batalhões, mas precisam de uma área para aportar e despejar as forças no território inimigo.

Um bom exemplo recente sobre a questão da acessibilidade é a Guerra do Iraque. Este país tem certas facilidades em relação à sua acessibilidade, pois a sua entrada pelo Golfo Pérsico é favorável ao desembarque pelo Kuwait, nação aliada dos Estados Unidos, cujo relevo é marcado pelas planícies do Tigre e Eufrates, favorecendo a mobilidade de tanques pesados. A população iraquiana é concentrada na região da capital Bagdá. Todos esses elementos favorecem uma guerra de conquista. Já o Irã não apresenta boas condições de acessibilidade. O desembarque pelo Golfo Pérsico não é tão fácil, pois os portos são bem protegidos pela marinha iraniana e o difícil acesso favorece a defesa. As cadeias montanhosas do Platô Iraniano dificultam acessibilidade para os carros, a população bem distribuída pelo território dificulta uma guerra de conquista. A atual tese do governo americano é ampliar os esforços de guerra no Afeganistão, que possui uma posição central e dá mais acessibilidade ao Irã, do que as áreas de planícies do Iraque. Por ser mais alto (e tendo maior importância aos interesses atuais dos Estados Unidos) permitem às forças estadunidenses pressionar tanto o Irã quanto Paquistão tornando-se assim base ideal para movimentações de suas infantarias treinadas para operações em montanhas e cavernas.

Os acidentes geográficos não são imperativos para empreender a realização de uma empreitada estratégica e nem poderiam ser; estes, simplesmente, facilitam ou dificultam as operações. Não acreditar nisto seria engendrar um conceito hipertrofiado das questões geográficas e criar um determinismo unilateral com a natureza mesma da guerra. Um general ou um chefe do Estado Maior, quando habituado a uma interpretação correta dos acidentes geográficos sabe que vencer o acidente geográfico (quando a manobra o impõe); evitar o acidente geográfico (quando o tempo e o espaço permitam) e, por fim, utilizar o acidente geográfico com fins relativos à economia e as forças armadas. 
A mobilidade envolve a habilidade de se movimentar como um todo. Isto inclui a velocidade das unidades, a liberdade de escolher o sistema de transporte, o fluir do tráfego e engarrafamentos, os efeitos sazonais do clima e a existência rotas prontas e facilidades terminais. Como uma expressão de capacidade e flexibilidade no movimento, a mobilidade não depende apenas da direção do movimento, mas também do que deve ser movimentado e da organização deste movimento. Dessa forma, as armas pesadas são menos móveis do que as armas leves, equipamentos autopropulsados são mais móveis do que equipamentos rebocados e tropas organizadas são mais móveis que civis refugiados desorganizados. Um bom exemplo da questão da mobilidade vem da Guerra de Secessão Americana. "A fotografia, o telégrafo, os foguetes de sinalização, os balões de observação e os trens tiveram sua estreia como artefatos de uso militar na Guerra de Secessão" (MARTIN, 2006: 246). A descrição da dificuldade de mobilizar um grande exército era enorme:

\footnotetext{
Para se ter uma ideia mais precisa dos volumes mobilizados, considere-se que um exército de 100 mil homens consumia mais de 600 toneladas de suprimentos por dia, o que exigia 2,5 mil carroças e 35 mil animais de tração, os quais também precisavam ser alimentados. Cada grupo de 80 carroças, carregando munições e víveres, e contando com algumas ambulâncias, cobria $1 \mathrm{~km}$ de extensão, de modo que o abastecimento do exército de 100 mil homens exigia uma fila de carroças de $30 \mathrm{~km}$. (MARTIN, 2006: 246).
}

A visibilidade abarca o campo de visão horizontal e vertical, ou do sensoriamento. Antes da era pré-eletrônica, a visibilidade tinha uma importância grande na inteligência das forças armadas. Depois, com a invenção do telegrafo elétrico, na metade do século XIX, e com a sua substituição pelo rádio, a comunicação passou a ser mais importante do que a visibilidade (ainda hoje, do ponto de vista tático, a comunicação via rádio é importante, pois seu resultado é imediato no campo de batalha). Antes mesmo das tão comentadas imagens de satélite, as fotografias áreas já eram usadas em balões. Em 1849, o Coronel Aimé Laussedat, um oficial do exército francês, utilizou um sistema fotográfico desenvolvido por Daguerre embarcado em um balão para obter fotos cuja finalidade era o mapeamento topográfico. As 
fotografias aéreas e os balões foram intensamente usados da Guerra de Secessão Americana e mais tarde na Primeira Grande Guerra Mundial. Mas, atualmente, as imagens de satélite com definição de até um metro são imbatíveis no que diz respeito à visibilidade, podendo acertar com precisão a quilômetros de distância. "A visão é, naturalmente, o meio principal e mais imediato de obter inteligência em tempo real. Era assim na era pré-telegráfica e voltou a ser assim na era da imagem visual eletrônica" (KEEGAN, 2006:37).

Comunicabilidade significa a habilidade para transmitir informação. Isto inclui os efeitos do tempo atmosférico, tempestades magnéticas, aspectos do território, existência sobre desenvolvimento cultural, facilidades de construção, eficiência operacional e manutenção dos sistemas de comunicação. Os aspectos geográficos estão relacionados a condições em lugares específicos, que podem mudar a área ou influenciar os sistemas de comunicações, como, por exemplo, numa população esparsa com pouca infraestrutura é menos apropriada para comunicação do que as áreas urbanas. A comunicação com essa tecnologia geralmente acompanha as linhas de estradas de ferro e rodovias. Após a invenção da comunicação via satélite, tornou-se possível coordenar operações dos Estados Unidos em lugares tão distantes quanto o Oriente Médio, ou até mesmo na Lua, se preferir. Em alguns lugares, montanhas e florestas podem atrapalhar a transmissão de comunicação e restringir a eficiência do comando favorecendo a descentralização das atividades militares.

Disponibilidade é uma palavra de uso comum, mas, neste caso, é aplicada à estratégia. Este conceito aparece em importância não apenas por expressar a existência de soldados, equipamento e suprimentos, mas também pelo planejamento de se estar no lugar certo, na hora certa e na quantidade adequada. Então, segundo PELTIER \& PEARCY (1966), a disponibilidade não expressa somente o contingente, mas a quantidade e a localização. $\mathrm{Na}$ Segunda Guerra Mundial, o petróleo que abastecia a Itália não era disponível para as suas forças no Norte da África e a fabricação da munição dos aliados produzida no continente americano tinha que estar disponível para Inglaterra, Rússia, China e áreas no Norte da África. Portanto, a disponibilidade reflete o efetivo, suprimentos, transporte, pré-posicionamento e outros aspectos de 
suporte material. Isto reflete as características do grau de desenvolvimento, da organização destas importantes funções e para suporte da organização militar.

O último dos seis elementos da geografia estratégica é a vulnerabilidade. Difere dos demais, pois aqui não está em jogo o que alguém pode fazer, mas sim o que pode ser feito por alguém. Expressa, portanto, o produto acabado, finalizado, a capacidade de acesso do inimigo, o movimento e a disponibilidade. Inclui-se a necessidade das pessoas, facilidades da produção, instalações militares e as rotas de transporte para proteção. Também os aspectos psicossociais como: o estado de bem-estar, subsistência da população, moradia, infraestrutura pública, lazer e outras necessidades que mantêm a moral e a lealdade da população ao Estado. Inclui não somente a precisão das forças militares estarem prontas para um ataque direto, mas, também, estarem protegidas contra a propaganda, a sabotagem e outras coisas desta natureza.

Logo, existe uma profunda relação entre a estratégia e a Geografia Militar; sua influência se faz sentir tanto no planejamento como na condução das operações militares.

Acerca do conceito "Geografia Militar", cabe trazer para o debate um best seller da geografia civil, o livro "A Geografia - isso serve em primeiro lugar para fazer a guerra", de Yves Lacoste. Nesta obra o autor diferencia, de maneira bastante astuta, a geografia dos professores (ou geografia universitária) da geografia do Estado-Maior: o segundo conceito é muito mais antigo, vindo de uma percepção empírica (ou seja, da prática); já o primeiro, ao negar o segundo, escamoteia o seu real propósito, que é dar base para segundo.

Para Lacoste (2008:31), a geografia do Estado-Maior se define da seguinte maneira:

a geografia do Estado-Maior é um conjunto de representações cartográficas e de conhecimentos variados referentes ao espaço; esse saber sincrético é claramente percebido como eminentemente estratégico pelas minorias dirigentes que 0 utilizam como instrumento de poder. 
E a geografia dos professores é, por sua vez:

A outra geografia, a dos professores que apareceu há menos de um século, se tornou um discurso ideológico no qual uma das funções inconscientes, é a de mascarar a importância estratégica dos raciocínios centrados no espaço. Não somente essa geografia dos professores é extirpada de práticas políticas e militares como de decisões econômicas (pois os professores nisso não têm participação), de poder que são as análises espaciais. Por causa disso a minoria no poder tem consciência de sua importância, é a única a utilizá-las em função dos próprios interesses e este monopólio do saber é bem mais eficaz porque a maioria não dá nenhuma atenção a uma disciplina que lhe parece tão perfeitamente "inútil".

Ainda é um grande tabu para a Geografia pensar que o conhecimento geográfico esteja relacionado com as questões estratégica e militar. Não foi tarefa fácil para Yves Lacoste suportar as críticas vindas por parte de seus colegas quando lançou seu revolucionário pensamento. A pergunta à qual se propôs responder com seu livro era: "Para que serve a geografia?" Ora, talvez esta não fosse a resposta mais adequada para o momento em que escreveu esta contestada obra, pois com a iminente possibilidade de uma guerra nuclear, a Geografia estaria nadando contra todas as correntes científicas que estavam a pensar um mundo em que a guerra não poderia ser mais uma possibilidade e deveria ser, de uma vez por todas, completamente descartada. Mas se nos debruçarmos na resposta da pergunta contida no título do livro e a repensarmos, acredito que o título faria mais sentido (e receberia menos contestação) na época se, ao invés da pergunta retórica, se perguntasse "Em primeiro lugar, para que serviu a Geografia?"

Quando a Geografia é colocada desta forma, existe uma crítica severa sobre a produção científica da disciplina naquele momento, que se posiciona neutra e acima de qualquer consciência sobre qual é a utilização de seus paradigmas. Quando a Geografia como ciência nega a existência do uso da geografia antes do surgimento desta como ciência, é a mesma coisa que negá-la em si mesma. E quando nos questionamos, "para que serviu a geografia, em primeiro lugar?", logo nos remetemos talvez a cinco séculos 
antes de Cristo, e encontramos Sun Tzu e sua "Arte da Guerra", livro no qual é realizada uma categorização do espaço para seu uso militar.

A crítica de Lacoste, por outro lado, não analisa esta discussão de maneira pormenorizada, pois, ao considerar que a "geografia dos professores" se proclama como ciência no século XIX, "os universitários de hoje consideram, todos, quaisquer que sejam suas tendências ideológicas, que a verdadeira Geografia só aparece no século XIX com os trabalhos de Humboldt" (op.cit., 2008: 25). Esquece-se que os trabalhos de Humboldt, mesmo sendo obra de alguém que era mais um naturalista que um geógrafo, fora usado pelos Estados Unidos com propósito de conquista.

Lembremos que Humboldt foi proibido de entrar no Brasil, mas ao entrar no México mapeou informações nevrálgicas sobre os fortes e fortificações e quantos soldados e quais tipos de armamento existiam. Em visita pela América do Norte, passou tais informações para nova república democrática da América, os Estados Unidos - que ele acreditava ser o farol da nova civilização - que utilizaram bem as informações conquistando todo o norte do México. Por sua vez, o território brasileiro se manteve intacto de invasões externas.

O Presidente Jefferson ficou encantado com os mapas de Humboldt, o qual mandou ser compiado, e o barão tinha livre passagem na casa branca. Ao longo dos 20 anos seguintes Humboldt enviou para Jeferson copias do seus livros que Jeferson respondia com longas cartas, algumas vezes discutindo sobre o futuro da América Latina. $^{3}$

Outro ponto para ser considerado foi a definição do conceito geografia do Estado-Maior. É apenas outro nome que se dá ao conceito Geografia Militar. Lacoste não utiliza este termo, restrito ao século XIX. O autor tenta se desvencilhar a todo custo deste momento em que a ciência geográfica começa a se institucionalizar. Vale sublinhar o fato de que a ciência geográfica começa a ser estudada pelas escolas de oficiais do exército francês no início

\footnotetext{
${ }^{3}$ MCINTYRE (1985): National Geographic, September 1985, Vol. 168, No. 3: "President Jefferson was delighted with Humboldt's maps, wich he sent to be copied, and the baron had free run of White House. During the next 20 years Humboldt sent Jefferson copies of his books an Jefferson responded with long letters, sometimes discussing the future of Latin America".
} 
do século XIX, sendo os conhecimentos recém-adquiridos utilizados na aplicação de técnicas e estratégias militares.

Segundo Philippe Boulanger (2005) ${ }^{4}$, na primeira metade do século XIX a Geografia Militar começa a ser ensinada na formação da elite militar francesa na Escola Especial de "Saint-Cyr" pelo professor Théophile Lavallée, que organiza os primeiros fundamentos desta disciplina em seu livro "Géographie physique, historique et militaire", publicado em 1832, reeditado em 1865 e em 1880.

Lavallée foi bastante influenciado pelo que havia ocorrido décadas antes da publicação da primeira edição de sua obra (op. cit., 1832): as guerras napoleônicas. $\mathrm{Na} 7^{\mathrm{a}}$ edição, em 1865, ele revisa sua obra diante das guerras internas na França, Itália, Argélia e a Guerra da Criméia (1852), que possibilitaram novos estudos no âmbito da Geografia Militar do continente europeu. Também nesta edição, Lavallée reivindica sua autoria teórica na disciplina Geografia Militar chamando-a de "minha Geografia Militar".

Eu o tenho modificado e corrigido inteiramente nesta $7^{\text {a }}$ edição; eu acrescentei à obra detalhes, que eu considero interessante, sobre as fronteiras da França, a Argélia, a Itália, a Criméia e etc. Finalmente, como minha Geografia Militar foi traduzida ou plagiada em várias línguas, eu consegui enriquecê-lo de informações que me foram trazidos de sábios oficiais estrangeiros: eu devo principalmente agradecer, a esse respeito, ao senhor Jackson, coronel da artilharia na armada britânica, quem publicou em Londres, em 1850, uma tradução inestimável de uma parte da minha obra sob o título de "A topografia militar do continente europeu do francês Sr. Th. Lavallée".

Lacoste, como visto, prefere a expressão "Geografia do Estado Maior", para ele mais antiga, porém livre das implicações semânticas advindas

\footnotetext{
${ }^{4}$ In: www.stratisc.org - acesso 05/06/08.

${ }^{5}$ LAVALÉE, T. (1865: prefácio da $7^{\mathrm{a}}$ edição) "je l'ai entièrement remanié et corrigé dans cette $7 e$ édition; j'y ai ajouté des détails que je crois intéressant sur les frontières de la France, l'Algérie, l'Italie, la Crimée etc.; enfin, comme ma Geógrafie Militaire a eté traduite ou imitée dans plusieures langues, j'ai pu l'enrichir de renseignements que m'ont fournis de savants officiers étrangers: je dois principalement à ce sujet de remerciements à $\mathrm{M}$. Jackson, colonel d'artillerie dans l'armée britannique, qui a publié à Londres, en 1850, une traduction remarquable d'une partie de mon ouvrage sous le titre de "The military topography of continental Europe from the french of Th. Lavallée" (op. cit. 1865).
} 
de sua forte institucionalização durante o século XIX. É bom lembrar, entretanto, que a própria "geografia dos professores" (aquela que foi institucionalizada e tem como grande fundador o naturalista alemão Humboldt), também desenvolveu conhecimentos utilizados nas guerras de conquista no México pelos Estados Unidos. A conclusão desta questão é que tanto a "geografia dos professores" quanto a geografia do Estado-Maior têm a mesma origem e que a resposta de Lacoste refere-se a outra pergunta: "Para que serviu a geografia, em primeiro lugar?" Ora esta serviu, em primeiro lugar, para se fazer a guerra. Hoje, diante da crise da civilização ocidental, anunciada como uma crise das relações humanas, a pergunta a ser feita deve ser outra: "A geografia - ou qualquer outra ciência - é imprescindível para se fazer a paz?"

\section{2) Guerra, Ideologia, Revolução: concepções da Práxis geográfica.}

O conhecimento do território é uma das matérias fundamentais que todo o comandante e seus encarregados devem estudar. É importante desde o comando das menores unidades de combate até os mais altos escalões, responsáveis pela discussão e elaboração das estratégias. Tal conhecimento deriva da geografia. Na estruturação e execução de qualquer ação bélica devem ser consideradas não apenas as condições do terreno, mas do território com todas as suas complexidades. Toda solução para uma dada situação tática ou estratégica requer conhecimento amplo e prévio do cenário de onde vai se atuar.

A Geografia Militar surgiu como um ramo da Geografia Geral e se ocupa dos estudos dos fatores geográficos, humanos, físicos, econômicos, políticos e militares e suas relações espaciais correspondentes ao cenário de guerra. Busca interpretar tais dados e relações para deduzir a influência que exercem na condição militar. Tem como objetivo, sobretudo, oferecer subsídios para que o estrategista avalie com maior precisão as vantagens e os inconvenientes de sua ação. Avalia, ainda, as implicações dos fatores 
geográficos no cerne social da guerra, contribuindo para a estruturação, manutenção e para organização das forças armadas de cada espaço.

O uso dos conhecimentos sobre geografia ocorre desde os tempos muito antigos, mesmo antes do surgimento das primeiras civilizações, quando as sociedades humanas tinham uma organização social mais simples, como os clãs e tribos, por exemplo. O conhecimento de um lugar seguro (como uma caverna ou mesmo uma fonte de água) deveria ser importante para o desenvolvimento do clã ou da tribo. Nas civilizações primitivas, as pinturas rupestres funcionavam como indicação de rotas de caças. Podemos encontrar aí, de certa forma, um prenúncio da tentativa do homem de sistematizar o espaço, utilizando não símbolos sofisticados da cartografia moderna, mas a própria arte como meio de orientação.

\begin{abstract}
Desde tempos imemoriais, quando os grupos humanos pouco se diferenciavam de seus "primos" mais próximos, isto é, dos demais primatas superiores, saber a localização de uma fonte de água potável, ter acesso a um determinado campo de caça e protegê-lo contra eventuais invasores, representavam conhecimentos vitais que hoje nós provavelmente denominaríamos de estratégicos (...). Além disso, esse conjunto de informações, técnicas e métodos, podia ir sendo ampliado indefinidamente, desde que evidentemente, a memória coletiva tivesse capacidade de armazená-los de alguma forma (MARTIN, 2004: 15).
\end{abstract}

O pensamento filosófico das teorias da guerra evolui da arte à ciência (lembrando que no Oriente a filosofia da guerra é parte das artes marciais que são demasiadamente complexas, com técnicas que vão da criação dos artefatos bélicos, passando a técnicas do manuseio, até a filosofia e religião). Os samurais japoneses tinham um ensinamento de regra e conduta para os guerreiros santos (os bushidos). Os indianos têm um dos quatro vedas, livros sagrados "Arthashastra" dedicado à política, diplomacia e guerra.

No século XIX, a ciência começa a ocupar o espaço das artes e ambas se dividem. Não existe mais uma grande arte guerreira que envolva técnicas, filosofias, religiões e sim manuais de como vencer as guerras em determinadas situações, ou quais erros que não poderiam ser cometidos pelos generais em condições específicas, levando-se em conta experiências anteriores. É verdade, também, que nem sempre situações anteriores podem 
servir como lição em momentos posteriores, pois cada caso é um caso e tem suas próprias especificidades. Mas toda experiência é válida e cabe ao líder do Estado Maior saber interpretá-las para melhor conduta de seus exércitos.

Não cabe nesta discussão realizar o levantamento histórico pormenorizado das teorias da guerra, pois o trabalho ficaria muito extenso, mas apresentar um breve levantamento de como as concepções geográficas evoluíram do pensamento antigo aos padrões atuais de apropriação do espaço por meios bélicos e quais proposições ainda são válidas hoje; ou mais, quais relações que se estabelecem diante da teoria e de uma experiência experimentada. Por essa razão, as escolhas de alguns teóricos específicos estão relacionadas à sua importância e relevância para o debate em questão.

Antes da análise destas teorias, cabe ressaltar que tal construção teórico-metodológica já foi bastante explorada. Heinrich Zimmer, autor de "Filosofias da Índia", demonstra muito bem como um princípio teórico, mesmo antigo e ligado a preceitos da religião como Arthashastra Veda, pode nos ajudar a entender a postura de algumas potências, através de uma leitura comparada.

$\mathrm{Na}$ Parte II de seu trabalho, o primeiro capítulo nos fala da filosofia hindu e de como obter êxito na administração pública e nas relações de poder. Neste veda encontramos fórmulas de como fazer alianças ou como trazer a paz para o reino, são preocupações que se estabelecem a partir da existência de um poder. Este compêndio de versos se encontra no Arthashastra Veda, e em outros compêndios como: Mahabharata, Ramayana, e outras fábulas indianas que nos falam, não só da espiritualidade, mas também, de estratagemas político-estratégicos. Essas histórias indianas citadas anteriormente sempre se passam em um reino onde o bem e o mal duelam para definir os desdobramentos políticos, sociais e afetivos.

Zimmer nos descreve a mandala ou círculo político de estados vizinhos que aparece no Arthashastra: "esta fórmula para dispor alianças e coligações estrangeiras é fundamentada num diagrama de anéis concêntricos que representam os inimigos e aliados naturais" (op.cit., 1986:89). O líder deve considerar seus domínios como o círculo central: seus inimigos naturais os que o cercam, e os seus aliados naturais os que cercam seus inimigos (ver a figura 
5), por fim, no último círculo uma ameaça remota. A mandala "delineia e torna manifesto certo equilíbrio e tensão entre forças naturais (...). Como princípio social válido universalmente, supõe-se que os vizinhos são propensos à inimizades, à inveja e agressão" (ibidem, 1986:89). Esta teoria pode ser vista como exemplo em vários episódios de conflitos durante a pax-Britânica no longo século XIX, onde se prevaleceu o balance of Power e, no caso mais evidente, as posturas políticas da França no século XVI, XVII e XVIII, como bem descreve o autor:

Quando aplicamos o antigo mandala da Índia ao mapa da Europa, obtemos um diagrama perfeito dos problemas e vicissitudes, dos acertos e dos aparentes enganos, que provocam nossas quase ininterruptas guerras. No começo da época moderna, no século XVI, a França encontrava-se ameaçada pelo cerco resultante da união entre a Espanha e o Império Germânico sob a dinastia dos Habsburgos. A subseqüente luta pela hegemonia entre os reis franceses e os imperadores de Viena- desde os reinados de Francisco I (1515-1547) e Carlos V (1519-1556) - estendeu-se até o desmembramento do Império Austro-Húngaro quando do Tratado de Versalhes em 1919. Luis XIV (1643-1715) "o mais cristão dos reis", que perseguiu os calvinistas huguenotes e os expulsou de seu reino - conseguiu o apoio dos turcos otomanos que estavam às costas dos domínios dos Habsburgos na Europa oriental. Então os turcos invadiram os territórios do inimigo desde que hoje é a (ex-) lugoslávia passando pela Hungria, enquanto os exércitos franceses lutavam contra as forças imperiais alemãs nos Flandres e ao longo do Reno. ${ }^{6}$

A partir do século XIX, formas de conhecimento, como a exemplificada acima, foram subestimadas pelo forte cientificismo que reinou e ainda reina entre nós. O intuito de a ciência substituir a religião fez com que Hegel classificasse-as como "proto-filisofia", distinguindo assim o conjunto de pensamentos milenares orientais como sendo primitivos $\mathrm{e}$ atribuindo ao pensamento dos gregos o valor de verdadeira filosofia.

\footnotetext{
${ }^{6}$ ZIMMER (1986): 90p.
} 


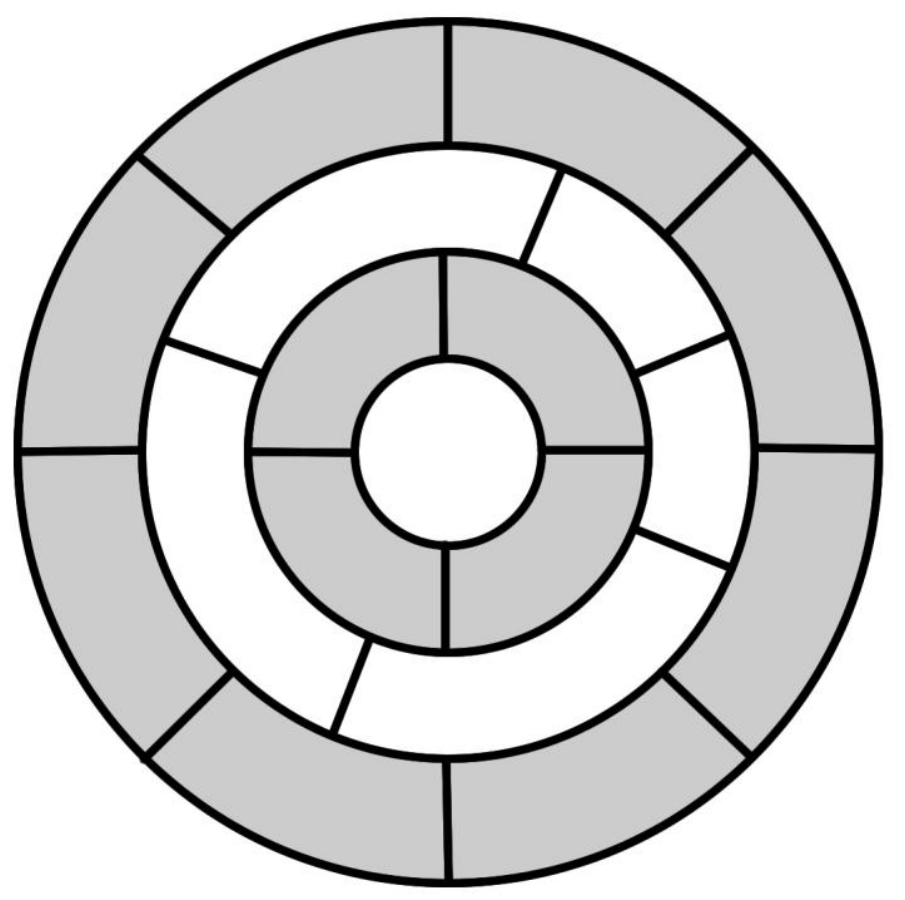

Figura 1 - Fonte: Filosofias da Índia. (ZIMMER, 1986:89). Organizado por Filipe Giuseppe Dal Bo Ribeiro

Atualmente, este é um paradoxo vivido nas sociedades orientais diante dos novos valores que são impostos pela globalização. Jogar fora todo o conhecimento transcendental das filosofias orientais e ficar com o pragmatismo científico? Zimmer mostra como pode ser feita a ponte entre tais filosofias e a ciência moderna.

O pensamento científico não deve ficar longe da origem da sistematização do pensamento da humanidade, que foram as religiões e as filosofias: nestas estão o motivo primeiro da curiosidade humana e que fez dos seres humanos muito diferentes dos outros seres vivos. Esta experiência deve sempre pautar todas as futuras indagações, para que não caiamos mais uma vez no erro de usar os conhecimentos desenvolvidos com interesses individuais, que não o interesse da humanidade - como foi feito com o desenvolvimento das bombas atômicas e é feito ainda hoje, na ânsia de se gerar lucros para poucos através da exploração da crescente miséria humana. A nossa atual ciência esta comprometida não com a melhoria da qualidade de vida, mas com um pequeno grupo de grandes corporações, enquanto 0 
pensamento das filosofias e religiões orientais estava mais relacionado ao desenvolvimento interior dos indivíduos, com o aperfeiçoamento do próprio indivíduo. Dessa forma, a mudança subjetiva era o suporte para a melhoria do convívio entre as diferentes sociedades.

Isto, também, não quer dizer que estas filosofias e religiões não consideravam o temperamento ávido dos diferentes indivíduos de diferentes sociedades. Alguns destes tratados religiosos, principalmente dos hindus, refletem situações políticas nas quais o poder é alvo de disputa e usado com fins pessoais (por isso a importância de se falar de política e de como usar melhor o poder, conseguindo a paz, prosperidade e tranquilidade para a população e para evolução espiritual).

Analisando a filosofia hindu, Zimmer, comparou certas situações experimentadas no berço da civilização ocidental e que repercutiram, segundo o autor, até o Tratado de Versalhes, em 1919, mas que podem ser reconhecidas na II Grande Guerra Mundial, como a oposição entre França e Alemanha e a posterior aliança da França com a Inglaterra - esta sempre com a intenção de estabelecer o equilíbrio do poder no continente, como já foi comentado anteriormente - muito próximo do esquema proposto pela mandala do poder no Arthashastra Veda.

Considerado o primeiro tratado sobre a guerra, a "Arte da Guerra", de Sun Tzu descreve e analisa o período da China Antiga conhecido como Primavera e Outono (722-481 a.C). Segundo o livro, neste período, o famigerado estrategista Tzu expõe de maneira brilhante questões sobre tática, estratégia, geografia (os sete tipos de terreno), e sobre as questões militares (organização, logística e disciplina). É verdade que os teóricos colocam em questão a existência de Sun Tzu, dizendo que talvez ele represente uma escola teórica marcial, assim como Sócrates entre os gregos - mas estas questões não serão discutidas neste trabalho. Da obra de Tzu, privilegiaremos o conteúdo referente à geografia aplicada ao exercício marcial em sua época afim de compreender a evolução do uso aplicado da Geografia em diferentes momentos, contrapondo os teóricos mais eminentes em cada uma dessas épocas. "Alguém que não está familiarizado com as montanhas e florestas, gargantas e desfiladeiros, com a forma dos charcos e pantanais, não pode 
fazer avançar o exército. Quem não lança mão de guias locais não pode obter vantagens do terreno" (SUN TZU, 2006:91).

Numa recente publicação de "A Arte da Guerra", de Sun Tzu e de "Métodos Militares" de Sun Pin (provável descendente de Sun Tzu) - obra que ficou perdida durante séculos -, Raphael Sawyer organizou e comentou, numa mesma edição (editora Martins Fontes, 2002, primeira edição), estas duas obras basilares do pensamento estratégico chinês antigo. A visão estratégica de Sun Tzu atualmente é aplicada em treinamento de executivos que leem os preceitos de a "Arte da Guerra" e empregam-nos ao mundo dos negócios, o que pode ser catastrófico sendo que o próprio pensador recomenda que 0 ápice da excelência não é vencer mais de cem batalhas e sim "subjugar o exército inimigo sem lutar" (op.cit.,2006:62). Portanto, é incoerente, em meio ao um ambiente de extrema concorrência, aplicar de maneira vã os ensinamentos de Tzu, que segundo as suas próprias palavras diz que "a guerra é o Tao do ardil" (ibidem, 2006:51). É por isso que observamos no mundo coorporativo jovens executivos com suas saúdes tão comprometidas, principalmente com problemas do coração e estômago.

Segundo Sawyer (2006), Sun Tzu viveu na China Antiga no denominado de "O período de Primavera e Outono" (722-481 a.C) no qual emergiram estados ligados a importantes famílias feudais entre as bacias dos rios Huang Ho e o Yangtse Kiang - Chou (a mais antiga), Wu (lar de Sun Tzu), Yueh (inimigo de Wu e que incorpora mais tarde o estado de Wu), Chin (que no final do período havia formado uma força capaz de usurpar o poder de Chou, e podia facilmente mobilizar 75.000 homens sempre que necessário), Ch'i (na costa leste junto ao mar Amarelo), Chao (ao norte) e Chu (que estimulou o pensamento de Sun Tzu pelo fato de possuir uma geografia peculiar na região). Então, na disputa pelo poder observa-se uma divisão bem clara: os Estados mais tradicionais ao norte do Estado de Chou e os novos estados que se encontravam ao sul, ao longo do Rio Yangtse Kiang, que eram menosprezados pelas famílias do norte mas cresciam rápido desenvolvendo áreas inóspitas. Sun Tzu previu muitas coisas ao fazer uma prospecção geográfica dos territórios do sul, Chin (principalmente), Chu e Ch'i, como foi analisado: 
O sul gozava de entre as quais um clima mais quente e produtivo, recursos aquáticos (hídricos) abundantes e extensos rios, lagos, montanhas e florestas densas. Um bastião natural que freqüentemente tornava inúteis as guerras que se utilizavam carros, o território desencoraja invasões pelo norte, ao mesmo tempo em que compelia o desenvolvimento das forças navais. Essas forças navais do interior aproveitam-se das habilidades que os nativos haviam desenvolvido para explorar os rios Yangtse, Han e Huai, os numerosos lagos e os extensos charcos. (SAWYER, 2006:2)

\section{Reinos Combatentes}

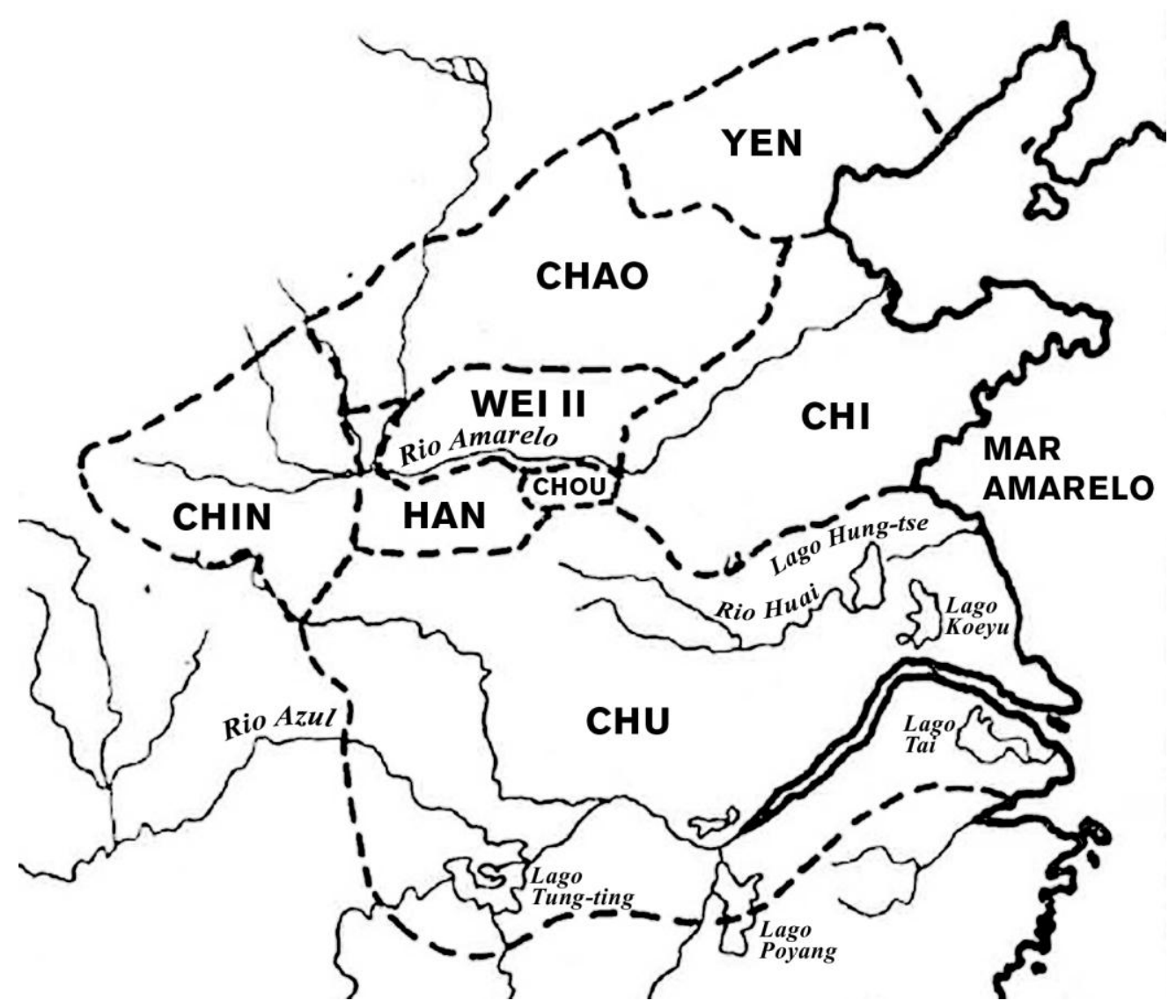

Figura 2- Fonte: La Geografia y la guerra: un analisis de sus relaciones (CEBRIAN, 1986:37). Organizado por Filipe Giuseppe Dal Bo Ribeiro (2010).

Sun Pin, o provavelmente descendente de Sun Tzu, viveu no "Período dos Reinos Combatentes" (403-221 a.C), no qual a guerra entre os estados feudais passou a ditar impreterivelmente a política e as relações entre os Estados. Neste período observa-se a predominância de quatro estados, Chin, Ch'u, Ch'i e Yueh. Chin, mais a oeste se fragmentou em três outros: Han, Wei e Chau, conhecidos como os "Três Chin" (ver figura 6). Chin, por sua 
posição estratégica se beneficiou da luta nos estados centrais "que ao final derrotou todos os poderes menores restantes, proclamando formalmente a dinastia Chin em 221 a.C., desenvolveu agressivamente sua base de poder no terrirório original de $\mathrm{Chou}^{7}{ }^{7}$ Neste período, a infantaria se transformou na principal força de combate substituindo de maneira importante os carros e a cavalaria. O general Sun Pin utilizava os carros não como força de combate e sim como suporte móvel, suas carretas de guerra.

Nos fundamentos de a Arte da Guerra, a primeira lição no primeiro capítulo Sun Tzu alerta que a guerra deve ser domínio do Estado e pode ter efeitos desastrosos como a extinção do Estado ou em certos casos como a única saída de sobrevivência dele. Sun Tzu divide o estudo em cinco partes: "O primeiro é denominado do "Tão", o segundo "Céu”, o terceiro "Terra", o quarto é dedicado aos generais e o quinto às leis da organização e da disciplina militar". (op. cit. 2006:51). Pelo menos uma parte é dedicada exclusivamente à geografia da guerra, e esta será alvo de debate e análises neste campo de discussão.

Em todos os capítulos Sun Tzu ressalta os fatores relacionados com a geografia da guerra como algo importante, pois dá forte ênfase à arte de mobilizar exércitos. No capítulo 2, intitulado "Realizando a Guerra", ressalta o planejamento e a organização militares para se realizar a mobilização das tropas e mostra o quanto isto custa para o Estado. O grande conselho é que a empresa da guerra não seja prolongada, pois isto pode atolar o Estado em dívidas e infelicidade geral da sociedade. Portanto, a guerra só é aconselhada se a empresa for rápida e trazer grandes vantagens para o Estado em questão.

País algum jamais se beneficiou de guerras prolongadas. Aqueles que não compreendem profundamente os perigos inerentes ao emprego do exército são incapazes de conhecer verdadeiramente as vantagens potenciais das ações militares. (op. cit. 2006:56)

Esta filosofia inicial pode muito bem ser pensada diante da política de guerra alemã no início da II Grande Guerra Mundial, a Blitzkrieg, ou guerra relâmpago, que previa ataques rápidos em lugares onde o inimigo não

\footnotetext{
${ }^{7}$ Ibidem (2006): 11p.
} 
teria força alguma para resistir. Foi assim com a Polônia, Áustria, Países Baixos, Bélgica e França. Entretanto, a Alemanha errou ao expandir a guerra para leste europeu com a União Soviética. Com o prolongamento dos conflitos, os extensos gastos militares alemães implodiram o Estado e quase puseram fim à Alemanha, rateada entre as potências vitoriosas ao fim do conflito.

No capítulo 3, "Planejando a ofensiva", Tzu desenvolve o seu postulado central, bastante relacionado com o estudo da Geografia Militar: "Aquele que conhece o inimigo e a si mesmo não correrá perigo algum em cem confrontos" (op.cit., 2006:64). Para isso se faz necessário conhecer sobre as potencialidades do Estado, da organização de seus exércitos, o ímpeto de seus generais e principalmente o território a ser atacado.

No capítulo 4, "A disposição militar", o estrategista chinês afirma que é a partir do território que deve ser feita as mediações necessárias para se obter uma melhor disposição de suas forças:

O terreno dá a luz à mediação; a mediação produz a avaliação dos exércitos. A Avaliação do exércitos dá origem ao cálculo do número de homens. O cálculo do número de homens da origem a ponderação da força. $A$ ponderação da força da luz a vitória. (op. cit. 2006:71)

Entretanto, os capítulos que Sun Tzu mais se dedica à arte do conhecimento do terreno são 9, 10 e 11: "Manobrando o exército", "A configuração do terreno" e "Nove terrenos", respectivamente. São nestes capítulos que o debate sobre a Geografia Militar é melhor desenvolvido no pensamento de Tzu, embora os demais façam referências diretas e retas sobre as vantagens de se conhecer o terreno do combate.

Por questões didáticas, começaremos nossa análise por "Nove terrenos" e "A configuração do terreno", no qual Tzu define cinco configurações de terreno que podem variar em nove tipos de terreno. "As principais configurações de terreno são cinco: acessível, suspenso, paralisado, restrito, íngreme e extenso" (op.cit., 2006:110).

Segundo Sun Tzu, acessível é aquele terreno no qual se pode prosseguir com facilidade, inclusive o inimigo; suspenso é aquele em que prosseguir é fácil, mas o retorno não; paralisado é aquele em que para ambas as partes não é vantajoso prosseguir; restrito é aquele que dá grandes 
vantagens quando ocupado primeiro que o inimigo (se for o contrário, não é bom que se siga adiante); íngreme é aquele em que só se deve ocupar as áreas mais altas; extenso é aquele no qual não é vantajoso travar combate. Sobre a configuração do terreno, Sun Tzu afirma:

A configuração de terreno é um auxílio para o exército. Analisar o inimigo, deter o controle da vitória, avaliar ravinas e desfiladeiros, o distante e o próximo, são o Tao do general superior. Quem os conhecer e os empregar no combate será vitorioso. Quem não os conhecer ou não os empregar no combate será certamente derrotado. (op. cit. 2006: 111)

Em "Nove Terrenos", Sun Tzu analisa e classifica nove tipos de topografia: terrenos dispersivos (quando os senhores lutam em seu próprio terreno); terrenos leves (quando a ocupação invasora não é profunda); terreno contencioso (quando vantajoso para quem ocupa); terrenos atravessáveis (de fácil travessia tanto para os aliados como para o inimigo); terrenos delimitados (a terra dos senhores feudais cercada de três lados de modo que quem chegue primeiro ganhará as massas de "tudo que há sob o céu"); terrenos pesados (quando se penetra profundamente em território inimigo); terreno capcioso (onde existem florestas, ravinas e desfiladeiros, pantanais e charcos: onde quer que a estrada seja difícil travessia); terreno cercado (onde a entrada é restrita, a volta é tortuosa, e com um pequeno número o inimigo pode atacar); terreno fatal (não traz vantagens a nenhuma das partes, quem lutar com mais intensidade sobreviverá e quem não lutar perecerá).

A Guerra do Vietnã é um bom exemplo de que os conselhos do antiquíssimo Sun Tzu devem ser considerados em sua relevância. Primeiro, os Estados Unidos não fizeram um plano de guerra rápido, o que elevou muito os gastos e desgastou suas forças na região. $O$ segundo preceito dos ensinamentos do estrategista chinês, que é conhecer o seu inimigo e a si mesmo, não foi levado em consideração. Sabendo que seu poderio militar era tão mais forte que o dos vietnamitas, os Estados Unidos acharam que a guerra não demoraria tanto. As forças norte-americanas estavam entrando em terreno capcioso e em terreno pesado. Ora, segundo os conselhos de Sun Tzu "em terreno capcioso se atravessa velozmente", e quando se entra profundamente no território, as forças devem se manter unidas. 
Os vietcongues, muito pelo contrário, seguiram - mesmo que instintivamente - os postulados de Sun Tzu, e fizeram com que as forças inimigas entrassem profundamente em seu terreno, acabando por dividir os exércitos "yanques" a fim de isolá-los em seu território, para atacar um a um em emboscadas. A prática da guerrilha faz parte dos métodos heterodoxos de Tzu: surpreender o inimigo onde ele não espera; "se ele é numeroso e nós pequenos ele é devagar e nós rápidos", isto num terreno lento é uma grande desvantagem para $\mathrm{O}$ assaltante. Portanto uma das táticas exitosas é justamente dividir e isolar o inimigo para que possa utilizar o território como vantagem em guerra.

Assim, se eu precisar a disposição do inimigo sem ter eu mesmo uma forma perceptível, posso concentrar minhas forças enquanto o inimigo esta fragmentado. Se estamos concentrados em uma única força enquanto ele está fragmentado em dez, então atacaremos dez vezes a sua força. Assim somos muitos e o inimigo é parco. Se pudermos atacar seus poucos com nosso muito, aqueles com que travarmos batalha ficarão extremamente pressionados. (op. cit. 2006:83)

As guerras do final do século $\mathrm{XX}$, quando os mega estados subjugam militarmente os países da periferia, têm o caráter de guerrilha e têm como principal teórico Sun Tzu. Pois não há como enfrentar um inimigo muito superior em armamento, organização, treinamento em confrontos diretos. Nestas situações, para Sun Tzu, a ética da guerra é manter o poder, mesmo que seja necessário usar as artimanhas, os métodos heterodoxos, dentre eles as guerrilhas. Temos diversos exemplos da luta de guerrilha na América Latina, África, Ásia como focos de resistência a forças maiores. No século XX e o início do século XXI, quando se observa o Oriente Médio, a situação não irá ser diferente.

Nos conflitos ocorridos nos primórdios da história da humanidade, conforme nos descrevem os escassos relatos disponíveis, os pequenos destacamentos eram compostos por bravos homens com um equipamento bélico bastante precário. Isto era a máxima força de que dispunham muitas das sociedades primitivas.

A partir de um dado momento, já se observa o desenvolvimento de uma máquina de guerra mais complexa em algumas civilizações. É neste 
ponto que o conhecimento geográfico passa a compor o rol de preocupações dos estrategistas. Possivelmente, o primeiro nome de vulto a fazer uso de tal método seria o imperador Alexandre - O Grande (356-323 a.C), instruído pelos pensadores que lhe eram contemporâneos, dentre os quais Aristóteles. Na medida em que cresciam os avanços tecnológicos, aprofundou-se, nas organizações militares, a capacidade de sistematizar o conhecimento geográfico para fins bélicos.

Visitantes estrangeiros vindos de terras distantes que mais tarde Alexandre, o Grande conquistaria recordam a insistência de suas perguntas a respeito do tamanho da população em seus países, da produtividade do solo, da direção dos rios e estradas que os atravessavam, da localização das cidades, baías e praças fortificadas e da identidade dos cidadãos importantes, feitas no tempo em que, ainda menino, ele reinava na corte da Macedônia na ausência de seu pai, Filipe, em campanha militar no exterior. (KEEGAN, 2006: 25).

Dentre os tipos de conhecimento que mais adiante sofrerão ampliações e maior foco de interesse, destacamos a busca de informações sobre outros povos, suas posições, suas possibilidades em caso de guerra, entre outros. Tudo isto se produzirá de forma mais definitiva com o nascimento da chamada política imperialista, que necessitará de uma estratégia de defesa a qual será fruto da intuição, ou das experiências em campo de batalha, concretizando cada vez mais os conhecimentos estratégicos. Durante os anos de seu domínio sobre a longa faixa de terras da Europa e da Ásia e parte da África, o Império Romano chegou a tal especialização sobre a guerra que toda sua organização social direta ou indiretamente estava voltada para o que dela decorria e até mesmo para o espetáculo que representava.

Quanto à movimentação no terreno, destaque na Geografia Militar antiga foi imperador Júlio Cesar (101-44 a.C). Este foi muito astuto no uso de informações geográficas para defesa e conquista de seus inimigos, visto que o império romano era cercado de inimigos por todos os lados. Ele reuniu dados sobre a Gália, Bretanha e outros territórios antes de ocupá-los e desenvolveu um sistema de inteligência militar que servia de informações bastante precisas num raio de até trinta quilômetros do teatro da guerra. Sobre a Gália, César 
relatou: "A Gália está toda dividida em três partes: uma habitada pelos belgas; outra pelos aquitanos; a terceira, pelos que em sua língua se intitulam celtas e na nossa galos" (CEBRIAN, 1985: 33). César elaborara um sistema de inteligência em várias escalas: as de curtas, médias e longas distâncias, "procursatores, que realizavam reconhecimento próximo, imediatamente à frente do exército; exploratores, batedores de longo alcance; e speculatores, que faziam espionagem nas profundezas do território do adversário" (KEEGAN, 2006:27).

Ao avançar no tempo, excluiremos deste debate as considerações apontadas por outros autores, historiadores-cronistas, que, interessados em incluir dados do ponto de vista estritamente militar, estavam mais preocupados com as grandes batalhas e suas táticas do que com a arte de conduzir campanhas em sua estratégia. Assim, o corte teórico poderia ser feito de maneira a incluir outros pensadores como Platão, Xenofonte, Aristóteles, que foram muito influentes no pensamento sobre a arte da guerra e influenciaram Alexandre Magno, Júlio César, os maiores conquistadores e generais da história ocidental - estes por sua vez impactaram de maneira basilar os pensamentos de Flavio Vegécio Renato (século IV d.C) e Nicolau Maquiavel (início do século XVI). A influência oriental é trazida principalmente por Marco Pólo, que com Kublaikan, o grande Kan, apreendeu muito sobre a inteligência da guerra e a informação.

Segundo Cebrian (1985), através de sua obra "Instituições Militares" (De re militari), que não versava sobre tática, Vegécio destaca um assunto pouco comentado até então na discussão da arte da guerra, o recrutamento relacionado com critérios geográficos. No primeiro livro, capítulo III, identifica que os melhores recrutas são os homens do campo, "que para a guerra não existe gente melhor que a do campo que é criada nas inclemências do tempo".( VEGÉCIO apud CEBRIAN, 1985:35). No entanto, quando for necessário recrutar os cidadãos - homens que vivem na cidade ou citadino - 0 trabalho para acostumá-los é intenso, sendo necessário separá-los dos deleites da cidade.

A maior contribuição de Vegécio à Geografia Militar se encontra na sua obra Geografia dos Mares, especialmente no mar Mediterrâneo. No livro 
V, "Da guerra do mar" - o pensador discorre sobre climatologia, o que ensinam as tempestades e os ventos, quais meses melhores para se navegar com segurança no mar Mediterrâneo, quais sinais anunciam tempestades, trata das correntes marinhas, da necessidade de conhecimento das costas, portos naturais, e das manobras das embarcações. Vegécio diz que "As boas elucidações da geografia dos mares e terrenos são mais úteis do que a força" (apud CEBRIAN, 1985:36).

Durante a Idade de Média, o avanço do pensamento militar ou da arte marcial, assim como dos conhecimentos da geografia, ocorreu no Oriente Médio. Os mulçumanos foram os que mais desenvolveram os conhecimentos da geografia neste período, enquanto que a Europa mergulhava na obscuridade geral. Kimble (2005), em "A geografia da Idade Média" destaca o apogeu desta cultura que salvaguardou o conhecimento dos pensadores gregos como Ptolomeu, que foi um dos mais importantes geógrafos da antiguidade, ao traduzir para o árabe muitas obras gregas que se perderam nos mosteiros romanos. Os conhecimentos geográficos foram desenvolvidos em sua expansão conhecida pelo nome de jihad - expansão do islã, traduzido como guerra santa - e a hajj - que é a peregrinação religiosa a Meca que todo o mulçumano deve fazer pelo menos uma vez na vida. Portanto, pelo costume de estarem sempre em movimento, os árabes reuniram rapidamente uma vasta sabedoria sobre os conhecimentos geográficos mundiais conhecidos da época.

Se alguém, no início do século VII, tivesse a audácia de profetizar que, dentro de uma década, um poder desconhecido, o dos povos da Arábia até então bárbaros e pouco conhecidos, pudesse surgir e afirmar-se perante as duas potências da época, tornando-se herdeiro dos persas e roubar dos bizantinos uma de suas mais bonitas províncias, inegavelmente poderia transformar-se em alvos de risos. E foi exatamente isso que aconteceu. Próximo à data da morte do Profeta (632), a Arábia tinha se transformado, como um passe de mágica, num viveiro de heróis difíceis de serem enfrentados. As campanhas militares de Al Walid e Al- $\tilde{A}$, que atravessaram o Iraque, Pérsia, Síria e Egito, estão entre as mais brilhantes na história das batalhas e podem ser comparadas com as de Aníbal, Alexandre e Napoleão (KIMBLE, 2005: 53).

Por estar numa posição central entre o ocidente e o oriente, a geografia dos árabes soube reunir dados e informações sobre a Terra, mais do 
que qualquer outra civilização daquele momento. Segundo Kimble (2005), no século $\mathrm{XI}$, os árabes tinham a posse de informações sobre a costa leste da África até $20^{\circ}$ Sul (Sofala). No entanto, era absolutamente desconhecido o oceano Atlântico, o nordeste da Europa e o leste da Ásia, assim como para eles, das quatro partes da Terra, só uma delas era habitável; ao sul da linha do Equador estavam às áreas acúmenas, para usar o termo grego que bastante influenciou o pensamento da geografia árabe.

No oriente, no século XII, os mongóis foram grandes mestres na Geografia Militar. Gengis Kan (1155-1227), antes e durante suas operações militares, considerou de grande importância a obtenção de quantos dados fosse possível sobre os países próximos ou distantes de seu império. O seu objetivo era de conhecer as características geográficas, situação política, aspectos militares com a finalidade de proporcionar ao imperador um panorama geográfico e político das regiões descobertas. Mais uma vez, aparecem sistematizações similares aos componentes dos estudos de Geografia Militar e que foram necessários aos sucessores do mais famoso líder mongol.

Esta sistematização foi bem constatada pelo grande viajante italiano Marco Pólo (1254-1299), que em seus relatos demonstra como o Grande Kan (Kublaikan 1214-1294) usava seus mensageiros como informantes, e quais eram as informações mais importantes que eles deveriam trazer na volta de suas viagens. Os questionamentos de Kublaikan sempre diziam respeito a aspectos físicos - forma, extensão, relevo, solos, hidrografia, clima, fauna e flora; fatores humanos; tamanho da população, raça, idioma, religião cultura, nível de vida e saneamento; fatores econômicos - política econômica, moeda (sistema financeiro), produção, comércio, vias de comunicação; fatores sociopolíticos - fronteiras, organização sociopolítica, política interna e externa; fatores militares - estruturação das forças armadas, exército, marinha, recrutamento e mobilização, armamento e material. Se observarmos o fluxograma "Esquema Sintético para um Estudo de Geografia Militar", proposto por Cebrian 1985, perceberemos que o Grande Kan, mesmo que instintivamente, já realizava a sua própria Geografia Militar: 


\section{ESQUEMA sintético para um estudo de GEOGRAFIA MILITAR}

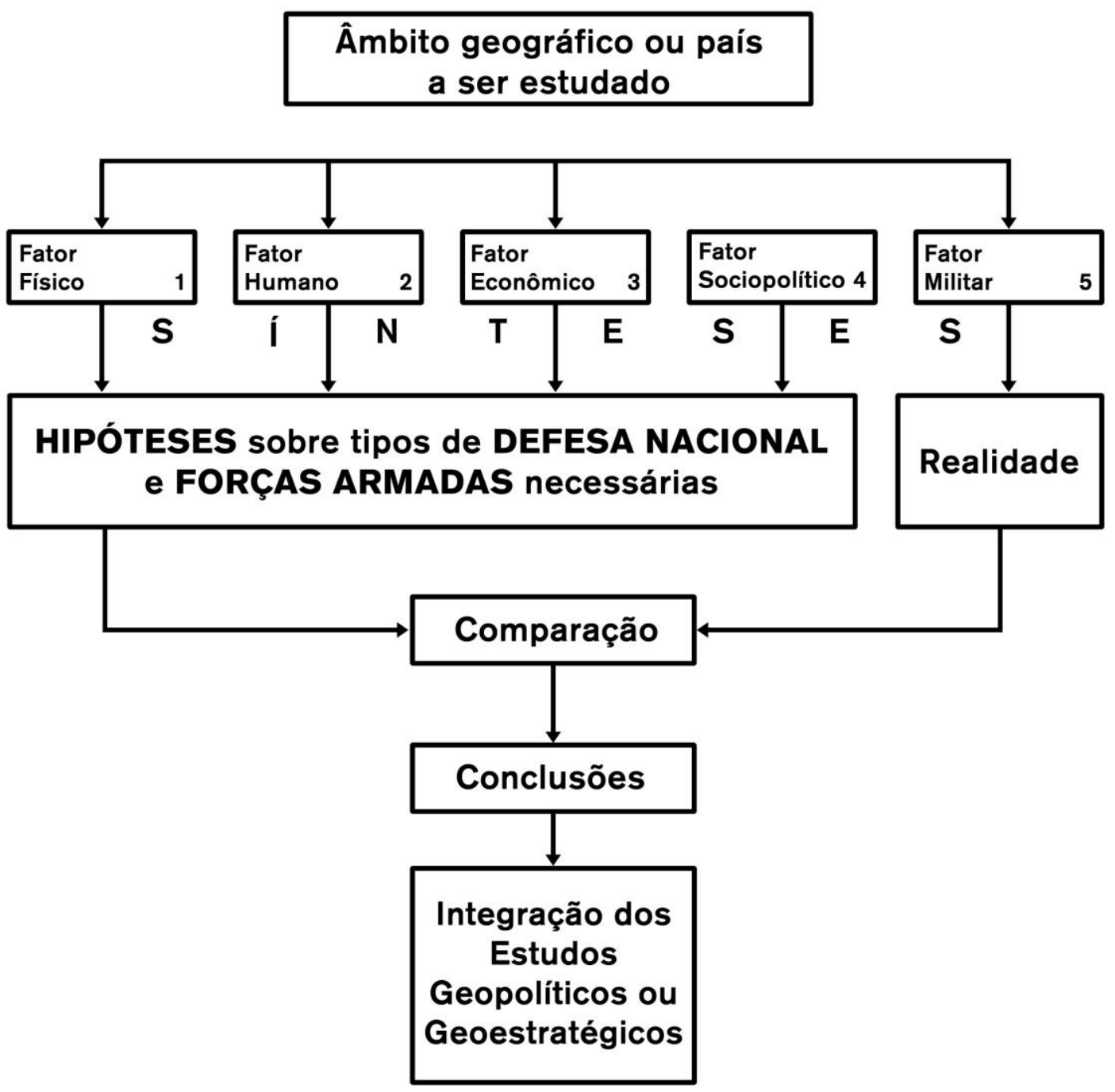

Figura 3- Fonte: La Geografia y la guerra: un analisis de sus relaciones (CEBRIAN, 1986:43). Organizado por Filipe Giuseppe Dal Bo Ribeiro

Avançando para o Renascimento, Nicolau Maquiavel aparece como aquele que inaugura o pensamento político moderno através de sua obra "O príncipe" (1513). Mas, nesse trabalho, nosso interesse é analisar o pensador do ponto de vista da Geografia Militar. Por aspecto, sua obra mais relevante é "A Arte da Guerra" (1521), verdadeiro tratado militar, escrito em prosa na qual Maquiavel expõe seu pensamento sobre a estratégia e sobre a arte do comando. 
Segundo afirma Lynch (2006) na introdução de "A arte da guerra" (edição publicada pela Chicago University, que se encontra traduzida na versão brasileira), Maquiavel é muito influenciado por dois antigos autores romanos, Vegécio e Frontino. Ele se apoia nas grandes façanhas de comandantes antigos como César, Alexandre e outros. "Entre estes estão Pelópidas e Epaminondas, Túlio Hostílio, Filipe da Macedônia, pai de Alexandre, Ciro rei da Pérsia, Tibério Semprônio Graco. Todos estes tiveram antes de criar um bom exército para depois combaterem" (op. cit. 2006:220).

Para a compreensão do pensamento de Maquiavel é necessário partirmos de sua vida e do contexto ao qual habitou. O pensador nasceu na Toscana e trabalhou na vida pública de Florença. A Itália, em sua época, era uma região alvo dos interesses dos nascentes estados absolutistas. Maquiavel era defensor da formação das milícias para a defesa das cidades-estados italianas, sobretudo em Florença. Sua crítica maior era sobre os exércitos mercenários que não combatiam com empenho necessário, pois não existia uma identificação com a região defendida.

Segundo Adverse (2006), o autor florentino reconhece de imediato o caráter necessário do exército próprio e associa a política à arte militar.

O profissionalismo militar como tal não apresentaria nenhum problema para Maquiavel; visto que os exércitos profissionais do criminoso e tirano Sétimo Severo e os soldados-cidadãos pagos da última república romana eram modelos de uma força militar eficaz e bem controlada. O problema parecia estar nas forças militares mercenárias ou auxiliares, não naquelas profissionais, pagas e controladas pelas autoridades políticas (que podiam até ser, elas mesmas, autoridades militares). ${ }^{8}$

O resgate da experiência dos tempos passados foi interpretado por muitos pensadores contemporâneos, segundo Lynch (2006), como equívocos de Maquiavel associados às mudanças tecnológicas que prenunciava uma transformação definitiva da tática dos combates como 0 advento da artilharia. Para o pensador italiano, o avanço tecnológico não substitui o bom soldado, mas o combatente era inevitável. Para Maquiavel,

\footnotetext{
${ }^{8} \mathrm{LYNCH}, 2006: \mathrm{LVI}$.
} 
portanto, inovações em tecnologias militares são úteis e necessárias, contudo, Ao tratar sobre artilharia no livro VII de "A Arte da Guerra", Maquiavel concluiu:

Os instrumentos com que os antigos defendiam as cidadelas eram muitos, como balista, onagros, escorpiões, arcubalistas, fundíbulos, fundas; e também eram muito os usados para o assalto, como aríetes, torres, manteletes, plúteos, víneas, foices, tartarugas. Em troca dessas coisas, hoje existe a artilharia, que serve a quem ataca e a quem se defende". (op.cit., 2006:206)

$\mathrm{Na}$ apresentação da edição brasileira do livro de Maquiavel, Adverse (2006) destaca o caráter de modernidade no pensamento do pensador. "(..) Encontramos uma unidade entre o poder político e o poder militar (...) além da imbricação, há uma espécie de homologia entre guerra e política" (op.cit. 2006:XII). Ora, esse pensamento irá ter um impacto no cerne do pensamento clausewtziano, que diz ser a "guerra uma simples continuação da política por outros meios". ${ }^{9}$ De acordo com Lynch (2006), "A arte da guerra" é uma referência ao pensamento militar de seu tempo, ao mesmo tempo, que às origens do próprio pensamento moderno: "o pensamento militar a partir do século XVI prosseguiu com base nos fundamentos lançados por Maquiavel". ${ }^{10}$

Segundo o italiano, a cidadania estava associada à vida militar sendo que a última poderia esculpir os melhores cidadãos. Lynch (2006) afirma que "a inovação de Maquiavel deve mostrar que a natureza humana pode ser aprimorada por meio da virtude militar" (op. cit 2006:LII). De certa forma, isto é uma resposta às proposições de Vegécio, que encarava a sociedade de maneira mais determinista, sendo, para ele, o homem do campo muito mais propenso para a vida militar. Maquiavel pensava que a vida militar moldaria os cidadãos que defenderiam a sua soberania, assim, não sendo submetidos aos exércitos mercenários que dominavam as defesas das cidades-estados italianas. Nas palavras de Fabrizio, o condottiero de "Arte da Guerra", Maquiavel realiza uma intertextualidade com Vegécio, mas adaptada à realidade do momento. Ele responde a seguinte pergunta de Cosimo: "de onde julgais melhor extrair os homens, da cidade, ou do campo?"

\footnotetext{
${ }^{9}$ Ver CLAUSEWITZ (2003), "Da Guerra".

${ }^{10}$ GILBERT apud LYNCH, 2006: LXIII.
} 
FABRIZIO Todos os que escreveram sobre isso concordam que é melhor escolhe-los no campo, por serem homens avezados ao desconforto, criados na labuta, que tem o costume de ficar ao sol, fugir à sombra, lidar com ferro, cavar fossos, carregar peso, não ser astuciosos nem maliciosos. Mas neste assunto a minha opinião seria que, em havendo necessidade de soldados de dois tipos, a pé e a cavalo, que os peões fossem selecionados no campo, e nas cidades os montados. (MAQUIAVEL, 2006:24)

No livro $\vee$ de "A arte da Guerra", Maquiavel (Fabrizio) começa o debate destacando a importância da qualidade informação para a movimentação das tropas na época dos romanos: "deveis saber que nos exércitos romanos, de ordinário, sempre se mandavam algumas turmas de cavaleiros como especuladores do caminho (...) mandando-se à frente a cavalaria ligeira para reconhecer o terreno" (op. cit. 2006:139). Na sequência, o autor começa a discorrer sobre geografia da guerra. Sua primeira grande advertência é sobre o terreno desconhecido com matas e montanhas (aquilo que Sun Tzu chamaria de terreno capcioso). "E maior deverá ser a diligência quanto mais favorável a emboscada for o território, como o são as regiões com muitas matas e montanhas, porque as emboscadas sempre são feitas em selvas ou atrás dos montes" (op. cit. 2006:153). Com exército em marcha em terreno desconhecido, a tropa deve redobrar os cuidados, marchando unida, sempre atenta às possíveis surpresas do território. Assim diz o autor: "e a primeira coisa que deve fazer é ter a descrição e o desenho de todo o território por onde vai passar(...), a quantidade de pessoas, as distâncias, os caminhos, os montes, os rios, os pântanos e todas as suas qualidades" (lb. ibidem, 2006:154).

Quando é questionado por Batista, Maquiavel ainda expôs sobre a questão do clima. Se é melhor continuar a guerra durante o inverno (como se faz hoje), ou só travá-la no verão. Sua resposta parece uma profecia ou um conselho pouco levado em conta nos dias de hoje, quando os dirigentes não analisam as coisas com cautela, apenas buscando a dominação. Fabrizio (Maquiavel) responde:

FABRIZIO Nada há de mais imprudente nem mais perigoso que fazer guerra durante o inverno; e a muito 
mais perigo está exposto a quem a faz do que quem a sofre (...). Por outro lado, nada há de mais inimigo da ordem que os terrenos ásperos ou o tempo frio e chuvoso; porque o terreno áspero não te permite espalhar teus homens como exige a disciplina, enquanto o tempo frio e chuvoso não te permite mantê-los juntos (...). No entanto deveriam ver quantos prejuízos lhes causou o hábito de guerrear durante o inverno e lembrarse de como os franceses, no ano de mil quinhentos e três, foram derrotados junto ao Garigliano pelo inverno, e não pelos espanhóis. Porque, como vos disse, quem ataca tem mais desvantagem: o mau tempo fere-o mais, por estar em casa alheia (...) (op.cit., 2006:193-194).

Esse conselho parece ter sido menosprezado por vários comandantes, ou por acreditarem excessivamente em si mesmos, ou simplesmente, por não levarem-no em conta como válido para os seus dias. Napoleão, que dizem ter tido contato com a obra de Maquiavel, deve ter lido com muita dor estes conselhos depois que perdeu a guerra na Rússia, num inverno considerado um dos mais rigorosos daqueles tempos. $O$ inverno e outras questões climatológicas seguiram influenciando os rumos das batalhas. No espaço marítimo, a tempestade afundou uma das maiores frotas daquele momento, a "Armanda Invencível", naufragada em 1588. Mas sobre os ventos e mares, Maquiavel se curva a Vegécio, mesmo sem citá-lo. "Sobre o mar não teria a pretensão de falar, por não ter conhecimentos sobre ele" (op.cit., 2006:218). Esta passagem é uma clara referencia à "A Geografia dos Mares", de Vegécio.

Nas considerações seguintes, como os outros pensadores, Maquiavel continuou a linha de ressaltar as qualidades militares do terreno para sua utilização tática em caso de guerra. $O$ território pode ser usado para emboscadas, como já foi colocado, e como apoio em obstáculos, também em obstáculos artificiais, como a fortificações de cidades ou postos avançados como é descrito no Livro VII - neste trecho o autor ressalta a importância deste conhecimento quando o exército é inferior ao do inimigo. $O$ autor florentino ressalta a importância estratégica do sítio mais elevado e como se colocar a favor do vento, para reduzir a força de lançamento de armas de arremesso. 
Neste conjunto de regras o autor não descarta os métodos heterodoxos de se fazer guerra, algo que o distingue de todos os teóricos de estratégia. As artimanhas, algo muito falado pelos mestres orientais, que segundo Adverse (2006), Maquiavel denomina de inganno, dissimulação que deve ser aplicada tanto externamente (ou seja, contra o inimigo), como internamente, não devem ser de conhecimento sequer dos soldados. Estes não devem saber das intenções do comandante, nem a verdadeira situação do front de combate. No livro IV de "A arte da guerra", Fabrizio (Maquiavel) fala da importância da retórica como meio de persuadir e motivar os seus soldados a fazerem o que os comandantes realmente desejam:

Lede a vida de Alexandre Magno e vereis quantas vezes foi preciso discursar e falar publicamente ao exército; não fosse isso, depois que seu exército se tornou rico com o fruto das pilhagens, ele jamais o teria conduzido para os desertos da Arábia e para Índia com tanto desconforto e incômodo; (op. cit. 2006:136)

Com isso Maquiavel conseguiu unir, segundo Lynch (2006), o pragmatismo técnico da arte da guerra ocidental com a oriental. "o exército de Maquiavel amalgama elementos cruciais de exércitos não pertencentes ao Ocidente com elementos essências dos antigos exércitos romanos e gregos" (op. cit. 2006: LXXIII). No pensamento clausewitziano, como veremos adiante, não ocorre tal percepção.

Depois dos grandes erros cometidos pelos Estados Unidos no Vietnã, ao utilizar o modelo clausewtziano de guerra total (ou "ocidental"), o país passou, a adotar a estratégia de realizar guerras curtas destinadas a atingir os pontos fracos do inimigo, como foi feito na Guerra do Golfo Pérsico, na Intervenção em Kosovo, embora seja bem provável que na administração de George W. Bush Jr., a política estratégica dos Estados Unidos tenha se voltado às origens clausewitziana, ao se debruçar em uma guerra de conquista (o que pode ter sido fatal para os cofres e para saúde precária de sua economia), hoje, a atual administração Barack H. Obama, prega uma guerra a partir do Afeganistão, o que resultou na formação do Estado Islâmico em parte do território do Iraque e proximidades. Mas à medida que o tempo passa, os Estados Unidos se afundam em terreno profundo e capcioso, e os gastos com 
a guerra, ao que parece, ainda não diminuíram, nem mesmo em plena crise econômica, uma das maiores da história do capitalismo que afetam de maneira dramática a sua economia.

A grande questão sobre a guerra, do ponto de vista ideológico, aparece no pensamento de Lênin. Ele irá identificar a diferença entre guerra imperialista e guerra revolucionária, modificando a visão que se tinha até então do fenômeno da guerra. O revolucionário pensamento de Lênin dará substâncias teórico-metodológicas para classificar a guerra entre dois matizes maiores, como aponta BONANATE (2001), a primeira a guerra internacional ou interestatal que são exatamente aquelas guerras travadas entre estados que podem ser coalizados ou não.

BONANATE (2001) constrói uma ideia sobre três modelos de pensamento sobre a guerra pautado nas teorias da guerra: O Modelo Clausewtiano, o Modelo Culturalista e o Modelo Revolucionário. Todos partem da ideia que é explicitada em Clausewitz no seu clássico "Da Guerra": "a guerra é a continuação da política por outros meios". O caminho teórico sobre o fenômeno é uma crítica de um lado culturalista e do outro marxista-leninista sobre o pensamento do Prussiano.

O contexto do pensamento de Lenin é a Primeira Guerra Mundial, a guerra dos impérios; portanto era claro que os exércitos nacionais compostos de cidadãos de seus respectivos países lutavam pela causa das elites; é nesse contexto que surge o modelo revolucionário da guerra. Na concepção marxistaleninista, o trabalhador deveria converter a guerra imperialista em luta de classes, pois numa guerra imperialista apenas os das classes trabalhadoras é que se matavam mutuamente sem consciência de que os objetivos não seriam convertidos em benefícios para as classes trabalhadoras respectivas e, sim, em ganhos para as classes opressoras. Por isso, primeiro passo, para o pensamento de Lenin, seria realizar a luta de classes e depois convertê-la numa guerra contra o imperialismo.

Aqui que foi proclamado como "interesse nacional" aparece no paradigma de Lênin somente como interesse da classe governante e de modo algum como interesse da classe explorada. Assim, a filosofia de Lênin descreve a "verdadeira natureza da guerra" em termos de conceitos que 
não existem no esquema de pensamento de Clausewitz (RAPOPORT, 2003: XXXV).

O modelo culturalista é desenvolvido, principalmente, por dois pensadores, são eles: Liddell Hart, John Keegan. Eles desenvolveram seus pensamentos de forma pessoal. São pensadores que trilharam uma forma independente de analisar Clausewtiz e estão apoiados na questão cultural da guerra, fazendo uma crítica sobre o modelo clausewitziano. Entretanto, não conseguem superar totalmente a premissa principal do pensamento prussiano, "a política é uma continuação da política por outros meios". Não resolvendo a equação básica desta questão.

Liddell Hart interpreta as palavras de Clausewitz da seguinte forma: se a guerra é continuação da política por outros meios, empreender a guerra significa subjugar o inimigo a sua vontade. Mesmo que o autor prussiano diga que não se deve começar uma guerra por motivos fúteis, aquele que sabe interpretar as palavras de Clausewtiz percebe que a guerra total é o melhor caminho para o estabelecimento de uma política de estado. Liddell Hart constrói uma tese contrapondo a ideia de que o melhor tipo de guerra seja a guerra total.

Entre a caneta e a espada, Clausewitz não pensaria duas vezes. Se, para submeter o inimigo, usa-se a política e a guerra é tida como uma continuação da política e serve apenas a si mesma e para submetê-lo deve-se desarmar o inimigo, dessa forma, quem for mais sagaz, faz a guerra. São esses os preceitos de Clausewitz seguidos por seus leitores. Segundo RAPOPORT (2003), Clausewitz encara a guerra como um instrumento racional da política nacional, as palavras 'racional', 'instrumental' e 'nacional' são conceitos-chave do seu paradigma: a decisão de empreender a guerra deveria ser racional, no sentido de que deveria ser baseada numa avaliação de custos e lucros possíveis; a guerra deveria ser instrumental, isto é, deveria ser empreendida com vista a alcançar-se um objetivo e nunca por si própria; 'deveria' ser nacional e o seu objetivo ser o de satisfazer os interesses de um Estado nacional a fim de que fosse justificada toda a mobilização da nação em prol do objetivo militar. Para Clausewitz, diante do impasse entre fazer ou não 
fazer guerra, a primeira possibilidade sempre deverá ser a vitoriosa: em seu pensamento não existe o fato de não existir a guerra.

A militarização do Estado operou-se com especial rapidez na Prússia e com ela a cristalização do modelo clausewitziano de Estado nacional (...) Outra forma encontrada era alcançando fáceis vitórias militares. Estas foram obtidas nas curtas e decisivas guerras contra a Dinamarca (1864), a Áustria (1866) e a França (1870). Com estabelecimento do Império Germânico, em 1871, o Estado clausewitziano tornou-se quase uma realidade sob a forma da Alemanha imperial. (RAPOPORT 1996:XVII)

Liddell Hart afirma que, se Clausewitz tivesse interpretado bem as guerras napoleônicas, teria percebido a diminuição da França no cenário internacional como consequência direta do empreendimento de uma guerra total contra as suas nações inimigas. Esse projeto imperial não conduziu a França a submeter o inimigo à sua vontade e sim ser submetida na organização da Ordem da Santa Aliança. Para Hart, a guerra deveria ser pontual, guerras rápidas com objetivos diretos.

A análise de um modelo culturalista sobre a guerra também parte do teórico americano, John Keegan em "Uma história da Guerra”, ele rebate a máxima de que a guerra é uma continuação da política por outros meios com a tese de que a guerra é um fenômeno humano e, portanto, é anterior à política de Estados. Entretanto, sua conclusão conflui na direção da análise clausewitiziana não conseguindo superar de fato o seu pensamento. KEEGAN (1995) afirma que o modelo ocidental da guerra prevalece sobre as culturas milenares: Asiáticas e Latino-americanas; e, portanto, o mundo que vivemos hoje foi construído ideologicamente pelo prussiano, assim o estudioso americano classifica Clausewitz como o pai ideológico da Primeira Guerra Mundial. Seu trabalho é uma obra basilar, entretanto, não consegue propor uma teoria revolucionária que supere a condição idealizada em "Da Guerra", que a guerra seja uma continuação da política por outros meios.

Mas quem foi Clausewitz? Segundo KEEGAN (1995), Clausewitz era oficial de um regimento prussiano. Um regimento é uma unidade militar tradicionalmente comandada por um Coronel. "O regimento - semanticamente, a palavra liga-se ao conceito de governo - foi um expediente para assegurar ao 
Estado o controle das forças armadas" (KEEGAN,1995: 29). Dependendo da missão, país de origem e composição, um regimento moderno tem uma dimensão similar a uma brigada. Essencialmente, a diferença atual entre um regimento e uma brigada é que esta inclui subunidades de várias armas e serviços, enquanto que o primeiro inclui normalmente forças de uma única arma.

Segundo KEEGAN (1995), os regimentos têm origem nos exércitos mercenários que, com o advento da pólvora e artilharia, substituíram os exércitos senhoriais. "O bombardeio por artilharia móvel - uma nova arma utilizada com êxito pela primeira vez por Carlos VIII, sucessor de Carlos VII anunciou o fim do desafio à autoridade real dos senhores de castelos" (KEEGAN, 1995: 29). Esses regimentos começam a fazer parte da realidade e da paisagem europeia, um processo que teve início em 1490 com Carlos VII, e passam a se tornar instituições reais e mais tarde instituições nacionais. Aos poucos, os regimentos começaram a se parecer mais com milícias. Os coronéis eram responsáveis por preparar e administrar as unidades militares e - Estado pagava uma quantia do tesouro real para sustentá-lo. Os descendentes desses coronéis "ficavam contentes ao receber coronelatos da infantaria por favor real" (KEEGAN, 1995:29).

\begin{abstract}
Esses novos regimentos adquiriram rapidamente um caráter diferente daquele dos bandos mercenários ao final do feudalismo e das guerras religiosas (época vivenciada por Maquiavel), que geralmente debandavam quando os fundos secavam (...). Eles se tornaram instituições reais - posteriormente nacionais permanentes, ganhando amiúde quartéis-generais fixos numa cidade de província, recrutando na região circunvizinha e retirando seus oficiais de uma coterie de famílias aristocráticas. O 34ํㅡㄹ Regimento de Infantaria da Prússia, para qual Clausewitz entrou em 1792, aos onze anos de idade, era exatamente um regimento desse tipo. Fundado em 1720.(KEEGAN, 1995:30)
\end{abstract}

Clausewitz, ao pensar sobre a guerra, rechaça a ideia de fazer mais um tratado de arte sobre o tema. Na verdade, seu propósito é ver a guerra a partir do olhar da ciência, como um conhecimento investigativo, isto porque sua formação militar atrela seu pensamento totalmente ao tema, conforme afirma: "a guerra é um ato de violência destinado a forçar o 
adversário a submeter-se à nossa vontade" (op. cit., 2003:7). Em "Arte e ciência da guerra" (1973), o pensador prussiano se opõe de maneira impactante aos pensadores marciais orientais dizendo que não existe maneira de desarmar nosso inimigo e assim forçá-lo à nossa vontade sem guerra. Portanto, para Clausewitz não importa mais as artes marciais e sim a ciência da guerra. "(...) a arte pertence ao domínio da criação, da produção, mas quando se trata das coisas de investigação e saber a ciência é soberana" (op.cit. 1973:136).

Talvez as almas filantrópicas deem a ideia de que existe alguma maneira, alguma forma artificiosa de desarmar e vencer o adversário sem demasiado derramamento de sangue e que isto é a verdadeira arte da guerra. Por mais desejável que pareça, tal ideia não deixa de constituir-se num erro; um erro que convém eliminar. (op.cit., 1973:10) ${ }^{11}$.

Projetando o desdobramento do pensamento do prussiano, sua teoria mostrou como ideias podem ser demasiadamente influentes em nosso mundo podendo inclusive alterá-lo. A Europa, no início do século XIX, vivenciava uma política de desarmamento e, no fim desse mesmo século, os países se atiravam numa corrida armamentista levando aquele continente ao maior massacre humano da história da humanidade sendo, Clausewitz, considerado "O pai ideológico da Primeira Grande Guerra Mundial”(KEEGAN, 1995:39). Em 1818, época em que Clausewitz escreveu os manuscritos "Da Guerra", o continente europeu era completamente exaurido pelas guerras napoleônicas, conhecidas pelos europeus daquele momento como a "Grande Guerra”. A Guerra, na teoria de Clausewitz, deveria servir apenas a si mesma, além de ser uma continuação da política por outros meios. Isto fez com que durante o século XIX - sobretudo a partir da primeira metade - as potências europeias voltassem a se armar, sendo a Alemanha a principal artífice deste processo. "No século XIX, a Prússia foi efetivamente tomada por regimentos; em 1831, havia apenas quarenta deles, mas em 1871 havia mais de cem"

\footnotetext{
${ }^{11}$ CLAUSEWITZ, C. - Arte y ciencia de la guerra, versão em espanhol; Ramon Orzamazábal: "Tal vez las almas filantrópicas den en la idea de que existe alguna manera, alguna forma artificiosa de desarmar y vencer al adversario sin demasiada efusión de sangre, y que a eso tiendel el verdadero arte de la guerra. Por más deseable que ello parezca, tal idea no deja de constituir um error; um error que conviene eliminar". (op. cit, 1974:10)
} 
(KEEGAN, 1995:39). O militarismo levou o ocidente para uma escalada sem precedentes na história da humanidade.

A partir da década de 70 do século XIX, o pensamento prussiano irá impactar todo o pensamento político-militar, inclusive no Brasil. Em nosso país o debate sobre tal pensamento irá surgir na discussão da modernização do exército nacional e, por consequência, da modernização do Estado brasileiro. Neste caso, o poder do pensamento aparece como uma força irresistível aos interesses políticos na época, sendo aplicado num mundo em que a concorrência entre os Estados irá leva-los a uma destruição mútua, usando como força para o esforço da guerra as massas oprimidas. O cinismo irá ser o fio condutor da política. No caso brasileiro, isto será instrumento da repressão dos grandes movimentos de insurreição que iremos observar no final do século XIX e início do XX. 
Primeira Parte - Raízes da Geografia Militar no Brasil: uma abordagem geohistórica. 


\section{CAPÍTULO 1 - NAS TRILHAS DA GEOGRAFIA MILITAR NO BRASIL: A FORMAÇÃO DOS ESTADOS IBÉRICOS E "AS GRANDES NAVEGAÇÕES".}

\section{Introdução}

Buscar as raízes ou as trilhas do pensamento militar brasileiro, e assim da Geografia Militar no Brasil, é tarefa que vai além dos caminhos da ciência pura, pois, quando se estuda o fenômeno da guerra e dos combates, as trilhas se tornam fechadas e a visibilidade não é tão clara. Trata-se de um conhecimento estratégico, em boa parte confidencial, com acesso restrito. Entretanto, nos dias atuais, temos mais informações e nem todo o conhecimento é mais totalmente restrito. Muitas vezes a falta de clareza decorre da "nuvem" de informações aleatórias disponibilizadas ao pesquisador.

Um caminho teórico clássico para este estudo advém da ideia de que o pensamento militar é um reflexo do pensamento político de seu momento. Por esta razão, é necessário se estabelecer um paralelo entre o pensamento político e o pensamento militar para, assim, construir e estabelecer os aportes teóricos e metodológicos deste campo no âmbito da Geografia. Segundo PAULA CIDADE (1959), a Geografia Militar ontologicamente se insere no campo da literatura militar, assim como outros estudos militares. Podemos citar relatórios de guerra, descrições de atividades militares, biografias, política aplicada à atividade militar, história, romance, poesia, estudos sobre arquitetura militar entre outras.

Pode-se dizer que só a história militar e o que lhe diz respeito, bem como algumas obras de divulgação de princípios ou de fixação de aspectos da vida nacional, pertencem à linha mestra da literatura militar: compêndios de arte militar, descrição de certas atividades militares do tempo de paz ou de guerra, biografia, vida e costumes das velhas gerações militares, relações da política com as atividades bélicas, aplicações de ciências como a geografia nos domínios da guerra - e pouco mais. (PAULA CIDADE, 1959: 1). 
Para que se busque uma origem da Geografia Militar no Brasil, é necessário beber na fonte da literatura militar e discutir o que foi pensado sobre a Geografia e seus aspectos militares, tanto em momentos de guerra quanto em momentos de paz. Esta é a base documental que será usada na presente análise.

Outro campo do conhecimento que fornece bases para este estudo são os estudos geohistóricos; estes esclarecem de que forma os processos históricos foram relevantes para transformação do espaço e como as determinadas sociedades se apropriaram do espaço de formas particulares e, ao estabelecer limites, passaram a distinguir a forma que chamamos de território. No século XX, ficou mais claro o movimento político que teríamos nas relações internacionais: a organização da política mundial seria pautada na relação de estados-territoriais. A partir dos estudos Geografia Histórica é que será estabelecido o elo da aplicação da geografia para fins militares e da evolução da Geografia Militar.

É neste sentido que não podemos limitar a ocorrência Geografia Militar apenas a partir de sua ascensão a disciplina e estudo, no século XIX. No mesmo sentido, não podemos negar que antes da independência do Brasil já existia um pensamento militar e mesmo que, de forma precária, este tateava algumas questões geográficas. O território, por sua vez, sempre está sujeito a modificações em função das transformações políticas, embora seus aspectos físicos sofram transformações mais lentas, a não ser quando a ação antrópica é responsável por acelerar algumas destas transformações. É por isso que o entendimento da política como aspecto central deste levantamento nos sugere inserir essas análises no campo da Geopolítica.

O fato de haver os limites e fronteiras tomado lugar de destaque no âmbito da Geografia Política leva, no evoluir constante, às rivalidades em territórios contestados, a zonas de influência, envolvendo episódios históricos do passado e presente. No contexto se apresenta a Geohistória para introdução e explicação da Geografia Política. É, pois na Geohistória que se vai encontrar a gênese da formação territorial e constituição das fronteiras atuais. (CASTRO, 1980). 
A Geografia Militar é antecessora da Geopolítica. De maneira semelhante, o pensamento político que influenciou o pensamento militar teve sua origem na necessidade de pensar politicamente a organização da defesa do território. Segundo GILBERT (2001:47), a "ligação estreita e da inter-relação das instituições políticas e militares é a mais importante e também mais revolucionária ideia nas teorias de Maquiavel". Quando Maquiavel foi secretário do Gabinete dos Dez, comissão florentina encarregada das questões militares, percebeu a fragilidade de um sistema de defesa dependente de exércitos mercenários e, em dezembro de 1505, criou a Lei Ordinanza que determinou a organização da milícia florentina. Por isso Maquiavel acreditava que "as instituições políticas devem ser organizadas de maneira a criar condições favoráveis para o funcionamento da estrutura militar" (Ibidem, 2010:50). Isso porque a vida do Estado depende da excelência de seu exército no pensamento maquiavélico.

O pai do pensamento político moderno foi antes um pensador militar e assim se tornou um pensador político. De acordo com GILBERT (2010), "não é exagero dizer que Maquiavel tornou-se um pensador político porque era um pensador militar". A Geopolítica é um desdobramento dos estudos da Geografia aplicada à ciência militar, ou seja, da Geografia Militar. Antes de tatear o terreno da política, o pensamento militar experimentou a Geografia em sua totalidade para depois encontrar a política e misturá-la, criando a "temida" Geopolítica. "Sabendo-se que a Política se baseia essencialmente na História e que esta não dispensa a Geografia, que Ihe serve de quadro, condicionando seus princípios, impõe-se então a Geopolítica". (CASTRO, 1980:12).

Realizar-se-á um estudo analítico da evolução política de Portugal e de sua Geografia Militar. Mesmo em períodos de União Ibérica, quando a Espanha se torna soberana sobre o Império Marítimo de Portugal e assim passa a realizar uma influência política no Brasil, os luso-brasileiros incorporam muito do pensamento político-militar espanhol, mas não adotam exclusivamente os designíos desta "união", a não ser quando os interesses eram comuns. 
Não é exagero buscar essas raízes na formação do Estado Português e na posterior expansão marítima, realizada num momento em que os Estados europeus mais capacitados para tal empreitada ainda não comungavam de poder suficiente para isso. A Geografia Militar portuguesa nasce com a Revolução de Avis e com as navegações portuguesas no Atlântico Meridional. A cartografia portuguesa foi capaz de sintetizar os avanços cartográficos feitos pelos mouros e pelos latinos (catalães, genoveses e venezianos), assim Portugal reuniu os interesses das elites mercantis com os avanços do conhecimento cartográfico e das táticas de guerra absorvidos em confrontos contra os mouros e contra Castela. Conciliando esses fatores, não foi difícil para o Estado Mercantil português se atirar em aventuras pelo norte da África e ilhas do Atlântico Norte.

A influência da Espanha no final do século XVI, e primeira metade do século XVII, se fez sentir no pensamento político dos portugueses, pois esses últimos ampliaram seu território de tal forma que conseguiram criar uma enorme vantagem territorial sobre os seus vizinhos que estavam "ilhados" nos altiplanos andinos e ao sul lutaram guerras encarniçadas pelo domínio da Bacia do Rio da Prata. No Nordeste, a luta contra os holandeses é rico vertedouro de produção bibliográfica do pensamento militar brasileiro. Nesse momento - do Tratado de Tordesilhas até o fim da União Ibérica - surgem alguns comentaristas que realizarão análises sobre o teatro da guerra e até sobre táticas usadas contra os seus inimigos, história dos confrontos, personagens, armamentos e etc.

A aurora da Geografia Militar, na prática, nasce da necessidade do Estado de defender seu território ou ampliá-lo de alguma maneira, seja por guerras continentais ou, seja dominando rotas marítimas e comerciais, nesse caso o conhecimento da Geografia e o uso dela para chegar ao fim desejado tornou indispensável para política. De acordo com CASTRO (1980) a Geografia Militar é um ramo da Geografia Política.

As fronteiras criam, pois, no mapa geográfico uma unidade política historicamente complexa, levando tudo isso a Geografia Política a um alto grau de objetividade e desprendimento. É que não existem dois ambientes idênticos e muito menos dois Estados inteiramente semelhantes no mundo. E como na extensão da esfera de 
atividades dos Estados surgem sempre os esforços para proteção das fronteiras contra possíveis agressões, o fato leva o estudioso a outro ramo da Geografia Política - a Geografia Militar. (CASTRO, 1980:12).

Desta forma, Therezinha de Castro define no plano epistemológico a Geografia Militar e na sua função, como a ciência que surge a partir do esforço para proteção das fronteiras contra possíveis agressões. Temos que sublinhar o fato de que a autora fala de possíveis ações, portanto a Geografia Militar surge do fato de que os Estados para continuar existindo devem estar prontos contra possíveis agressões e não contra agressões de fato. É a ciência que reunirá o conhecimento necessário para se fazer a defesa do território.

\section{Formação do Estado Moderno de Portugal e a necessidade do desenvolvimento de uma Geografia Militar.}

A morte de Dom Sebastião - o infante português e sétimo rei da dinastia de Avis - em 1578 na batalha de Alcácer-Quibir não só resulta no fim da dinastia de Avis, mas atrai antigas pretensões castelhanas de unir a península lbérica. O nascimento de Portugal como o primeiro Estado moderno pode-se dizer que foi um efeito colateral de um problema de sucessão dinástica da casa portuguesa de Borgonha.

Em 1383, morre El-rei de Portugal Dom Fernando de Borgonha e sua única filha era a infanta Dona Beatriz, casada com Dom João de Castela. A burguesia mercantil portuguesa já com identidade distinta da castelhana apoia o mestre de Avis, D. João, para ser o regente e defensor do reino de Portugal ao invés de aceitar a união dos reinos de Portugal e Castela. Então, está deflagrada a Revolução de Avis 1383-85. Os castelhanos realizam uma tentativa de invasão militar para fazer valer os direitos de sucessão ao rei de Castela. Os dois confrontos mais decisivos deste contexto são: "O cerco de Lisboa" e a "Batalha de Aljubarrota".

Uma guerra desigual em número, pois as forças castelhanas eram mais numerosas ${ }^{12}$, sendo entendida numa visão mais ampla como um

${ }^{12}$ CARMO, Em “A batalha de Aljubarrota: Uma explicação geográfica”. (2006): 
prolongamento da Guerra dos Cem Anos $^{13}$, pois Castela era apoiada pela França e Portugal pela Inglaterra; este embate terá como vitorioso o lado português. Na Batalha de Aljubarrota, a infantaria portuguesa, usando os métodos ingleses com os "arcos de gales", arma que tinha o alcance e potência semelhantes aos da besta podendo chegar aos 12 tiros por minuto, e o uso da infantaria apoiada pelas vantagens do terreno para defesa como os pântanos, os chamados shiltrons ${ }^{14}$ com um sistema de lanças compridas para derrubar as cavalarias, consegue derrotar a grande cavalaria castelhana e francesa.

O cerco de Lisboa será marcado pela batalha naval do rio Tejo, quando as embarcações portuguesas, em menor número, conseguem derrotar os barcos castelhanos e abastecer Lisboa com suprimentos e dar condições de vitória para os lisboetas.

A vitória portuguesa inaugurou um período de expansão mercantil e de supremacia portuguesa na península lbérica frente aos seus rivais castelhanos ao longo do século XV: "Abril de 1384, junto à vila de Fronteira, deu-se a Batalha dos Atoleiros, batalha premonitória, na qual D. Nuno Pereira inaugurou em Portugal as táticas defensivas de inspiração inglesa" (CARMO, 2006: 19). Em julho, a Batalha do Tejo foi uma derrota tática portuguesa, mas reestabeleceu o abastecimento da cidade; por fim uma epidemia afetou $50 \%$ da grande frota castelhana e Portugal conseguiu afastar o cerco da cidade de Lisboa. (Ibidem, 2006)

Efetivo dos portugueses era de 9 mil homens enquanto o castelhano era de 42 mil homens. (61p.) ${ }^{3}$ Ibidem (2006):

Em Aljubarrota confrontaram-se, mais uma vez, as diferentes concepções da batalha que marcaram a Guerra dos 100 anos, com as adaptações próprias do estilo peninsular. A primeira vez que tal acontecera na Batalha de Najera, em 1367, e as forças conjuntas de Pedro o "Cruel" e do Príncipe Negro bateram a combinação franco-castelhana comandada por Henrique de Trastâmara e pelo Condestável francês, Du Guesclin. Alujbarrota provou que nem os castelhanos e nem os franceses aprenderam a lição. Importa por isso ter uma ideia geral das diferentes tácticas que em 1385 se chocaram na cumeeira de S. Jorge. (56p.)

${ }^{14}$ Ibidem (2006):

O sistema táctico inglês, decantado nos campos de batalha da Escócia, recebeu o retoque final com a dura lição da Batalha de Bannockburn (1314) contra os schiltrons (unidades de infantaria pesada) de Robert Bruce, que aguentaram sem ceder as sucessivas cargas da cavalaria inglesa as quais, incapazes de penetrar, se emaranharam e foram sendo empurradas para as fossas e "covas de lobo que os escoses tinham preparado. Vinte anos depois, em 1333, na batalha de Halidon Hill, já os ingleses, apresentavam a doutrina tática que Ihes iria dar vantagens contra todos os adversários, até o advento da arma de forgo. (58-59p.) 
A formação do estado português e a história de luta contra os castelhanos marcou a formação de uma Geografia Militar portuguesa do século XV e XVI. Influenciada amplamente pela cavalaria medieval, que lutava contra os mouros e pelas inovações inglesas no uso tático do terreno; outro elemento das origens de um pensamento político-militar português foi a navegação e a cartografia. Com esses três elementos: os ideais cavalheirescos, a infantaria do rei e as navegações oceânicas, Portugal reuniu, rapidamente, forças que nenhum outro rei ou lorde possuía para realizar uma expansão transcontinental.

As cartas portulanas, mais rústicas já eram usadas antes da escola de cartografia portuguesa ser modernizada pela escola catalãmaiorquina. A busca por um caminho alternativo para o comércio mundial visto que os turcos dificultavam a clássica via comercial pelo Oriente e fechariam as rotas comerciais do mediterrâneo em 1453, transferiu para o Oceano Atlântico o centro das relações comerciais, pelo menos até o século XX.

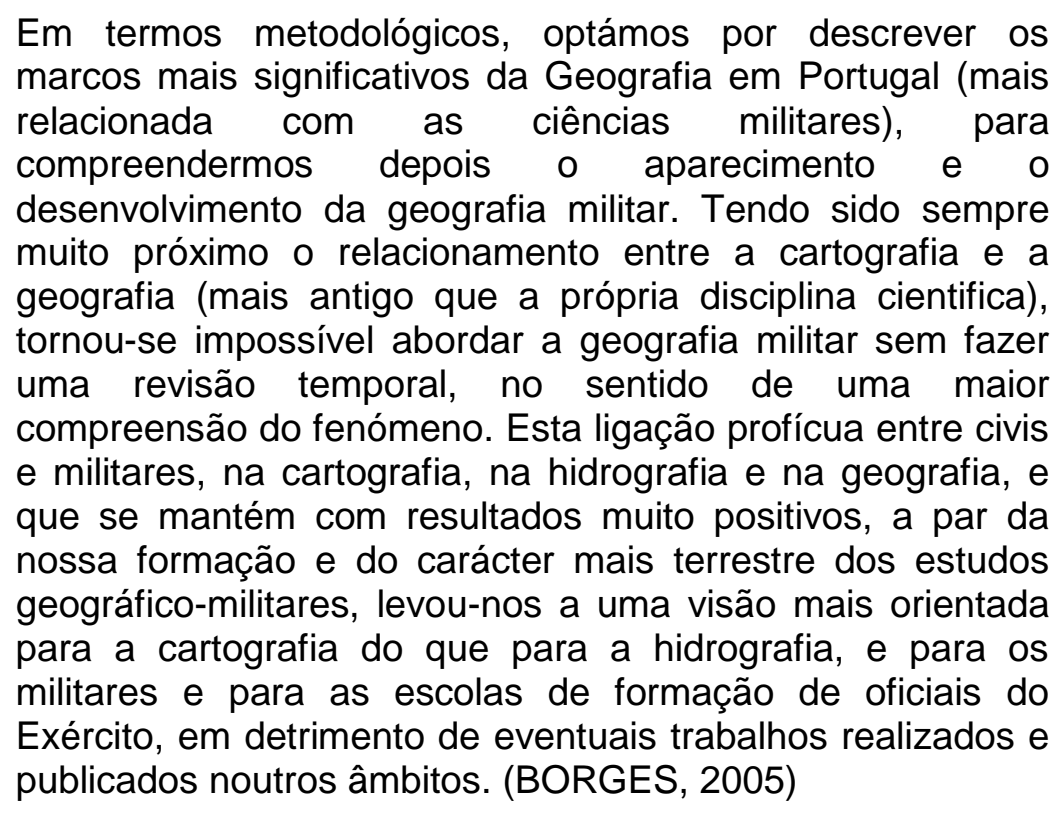

Segundo Albuquerque (1984: 64p.), 1443 é uma data provável para o aparecimento de uma cartografia portuguesa. "É, no entanto, o pequeno número das primeiras cartas portuguesas do século XV que se conhecem, devem ser todas situadas no último quartel desse século". O que indica que a escola de cartografia portuguesa foi subsidiária das escolas do mediterrâneo. Tecnicamente, a cartografia do século XV, em Portugal, foi influenciada pelo 
Mestre Jaime de Maiorca, isso indica uma influência catalã-maiorquina na técnica portuguesa. A precisão das cartas portuguesas ou de qualquer outra escola era bem questionável. Embora as técnicas de cartografia naval portuguesa não fossem tão avançadas quanto às das potências mediterrâneas, sua navegação e técnica de construção de navio para mar aberto eram mais avançadas do que a de qualquer potência europeia do século XV.

Que Jaime de Maiorca (ou Jafuda Cresques) tenha trazido para Portugal essa técnica de construir cartas é fato que vem sendo geralmente aceito. É certo que alguns the atribuem mais amplas missões, e até secundarizam a sua ação como cartógrafo, para salientar que ele veio para Portugal, sobretudo pelas suas qualidades de geógrafo, de cosmógrafo, de perito na arte de navegar e na construção de instrumentos (...). E quanto ao primeiro pressuposto ou seja, que o judeu maiorquino veio para Portugal ensinar Cartografia - sem o pôr definitivamente de parte, aceito-o com algumas reservas. Não que acredite, como Armando Cortesão acreditou, que a data da provável chegada de Jaime de Maiorca a Portugal, já aqui se faziam cartas há mais de um século; esta afirmação parece-me um descabelado exagero, sem o mínimo fundamento ou indício em que se apoie. Mas, seguindo a cronologia que é de uso propor para a vida e atividade de Jaime, teremos que ele chegou a Portugal em 1420; assim o diz, de resto, Duarte Pacheco Pereira (e o seu depoimento pesa) e o confirma também João de Barros (cujas afirmações são por vezes mais discutíveis). Em todo o caso, quando em 1420 chegou a Portugal, Jaime de Maiorca já não era novo; se, como querem os seus biógrafos, ajudou o seu pai, Abraão Cresques, a desenhar o célebre planisfério catalão de Paris, que data de 1375, não será muito atrevido dizer que mestre Jaime já rondaria, se é que não ultrapassava os sessenta anos. (ALBUQUERQUE, 1984: 59)

Segundo PAIM (2000), os portugueses souberam associar a influência da cartografia mediterrânica ao conhecimento empírico trazido pelos árabes e ambos têm como ponto de partida a influência da Geografia Ptolomaica e o empirismo advindo das práticas náuticas. "Vale a pena dizer: a Geografia de Ptolomeu foi ponto de partida inconteste" (2000: 42). A solução desta questão, se os portugueses desenvolveram ou absorveram a cartografia moderna, só foi encaminhada de forma mais adequada por Luís Rodrigues Semedo de Matos no II Congresso Luso-Espanhol sobre o Descobrimento e 
Expansão Colonial; publicados na Mare Liberum, Revista da História do Mar (número 10, dezembro de 1995), como afirma PAIM (2000:43):

\begin{abstract}
Tratando das navegações árabes e portuguesas no oceano Índico durante os séculos XV e XVI, Luís Jorge Semedo de Matos mostra como o conhecimento empírico acumulado pelos árabes permitiu aos portugueses, em tempo recorde, compor a cartografia daquela parte do Oriente. Assim, assinala que quando Vasco da Gama encontrou no oceano Índico, em 1498, os portugueses "tinham noção de que a Terra tinha forma esférica e conheciam uma maneira de referenciar posições nessa esfera (...). No entanto, é bom recordar que a exploração do oceano Atlântico demorou, pelo menos, setenta anos (1418-1488) de incessantes viagens, desde $\mathrm{o}$ infante $\mathrm{D}$. Henrique e da viagem à Madeira, até que Bartolomeu Dias que dobrou o cabo da Boa Esperança e entrou no oceano Índico. Em contraste com essa demora, vemos que três anos depois da chegada de Vasco da Gama a Portugal (1499) foi desenhado em Lisboa o chamado planisférico 'Cantino' (1502), onde aparece o oceano Índico com um rigor que nada tem a ver com as tradicionais representações dos séculos precedentes". Deste modo, o conhecimento geográfico pressupunha a acumulação de observações empíricas.
\end{abstract}

A imagem a seguir é o Planisfério de Cantino. De 1502, este é o primeiro mapa que mostra a descoberta do Brasil pelos portugueses; o original da carta está na Biblioteca de Estense, em Modena (Itália), pois o agente secreto Alberto Cantino subornou um cartógrafo português a mando do Duque de Ferrara e levou as informações para os italianos. Mas logo o planisfério de Cantino ficou ultrapassado pelos próprios portugueses, que realizaram um levantamento muito mais minucioso da costa da América Meridional.

No entanto, ainda não é um consenso científico creditar a Descoberta do Brasil a Pedro Álvares Cabral. Assis Cintra, em seu livro "Na Margem da História" e "Nossa primeira história", constata no Arquivo Reservado do Vaticano (livro138 - folha 148 e 149) que Afonso IV, em 12 de fevereiro de 1343, escreveu para o Papa Clemente VI o descobrimento da "Ilha Brasil" feito pelo capitão Sancho Brandão, como já havia sido citado pelo Brigadeiro Lysias Rodrigues (1937) em "Geopolítica do Brasil"; e, posteriormente, confirmado por Geraldo Cantarino (2004).

Um dia aportou em Lisboa um dos capitães - Sancho Brandão. Desgarrando-se no Mar do Ocidente, castigado 
pela tempestade e impelido por uma corrente misteriosa abordava uma terra magnífica, habitada por homens nus, opulenta em árvores de tinta vermelha. (Carta de Afonso IV para o Papa Clemente VI apud RODRIGUES, 1978:46).

Orgulhoso pela vitória conseguida e grato ao valente marujo que lhe dera uma terra nova, Affonso IV, batizou a grande ilha do pau vermelho com o nome de "Ilha Brasil". Em 12 de fevereiro de 1343, como era de praxe, comunicou ao Papa Clemente VI o acontecimento, em carta escrita de Montemór-o-Novo.' E assim se expressou: 'Diremos reverentemente a Vossa Santidade que os nossos naturaes foram os primeiros que acharam as mencionadas ilhas do Ocidente... (RODRIGUES, 1978: 46).

\section{Planisfério de Cantino (1502)}

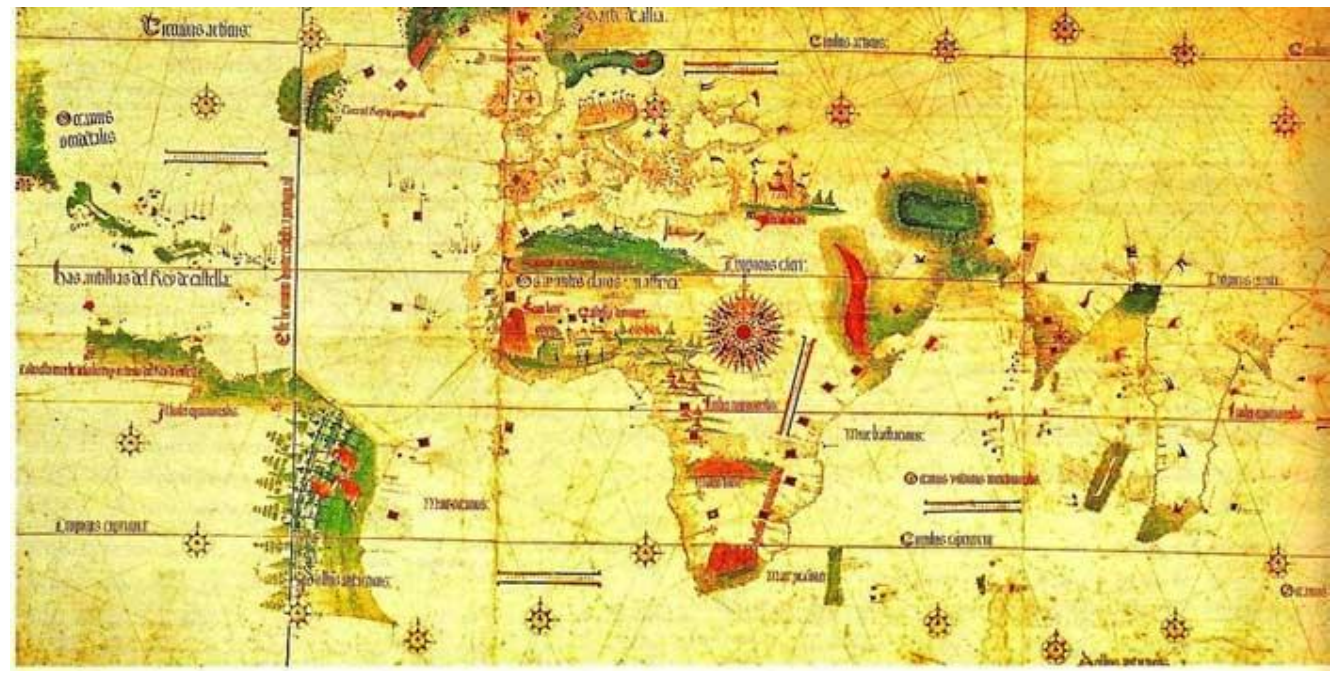

Figura 4- Extraído em:

http://museu.marinha.pt/Museu/Site/PT/Geral/PlanisférioCantinoumahistóriadeespiões.htm (acesso em 18 de junho de 2012).

E, posteriormente, confirmado por Geraldo Cantarino (2004), que até questiona o fato de realmente estas terras serem de fato o Brasil, e muito provavelmente serem as Ilhas dos Açores, mas "como explicar os nativos?" e das árvores de tinta vermelha? CANTARINO (2004), em seu livro "Uma Ilha Chamada Brasil: o passado irlandês no passado brasileiro", afirma ter requisitado ao vaticano os documentos secretos como se segue.

Meses depois, para minha surpresa, chegou uma remessa especial a ser retirada no correio da cidade de Dorking. Um envelope branco com etiqueta do Arquivo Secreto do Vaticano fez disparar a minha curiosidade. Entre duas lâminas de papelão reforçado, lá estava uma fotocópia da carta do rei português ao papa, escrita em latim, com a 
mesma referência indicada no livro de Assis. (CANTARINO,2004:234).

Esta questão é muito controversa: o "Descobrimento do Brasil" foi por um acaso ou foi algo planejado? Historiadores debatem o assunto sem chegar alguma conclusão exata. No Brasil, a pensadora Theresinha de Castro se debruçou nesta questão e levantou que o Brasil estava na rota do Atlântico. O interesse português por esta rota e seu planejamento estratégico e geopolítico para dominá-la ao longo do século XV e XVI faz com que o descobrimento do Brasil não seja algo que se tenha feito sem mais nem menos ou por um mero acaso.

Essa é uma das tantas questões que vamos debater em torno de pontos de vistas distintos que interpretam os mesmos fatos. Desses fatos, o mais importante era o périplo africano e o acesso as Índias. O Brasil, desse ponto de vista, foi o acaso, não estava nos planos dos portugueses. A outra interpretação diz que os portugueses tinham o plano de dominar o Atlântico Sul e com isso estabelecer uma hegemonia no hemisfério sul.

MARTIN (2007) nos chama atenção para o estudo realizado por Gustavo Barroso sobre a questão do nome "Brasil" e lenda medieval irlandesa que já localizava uma ilha remota a sudoeste da Irlanda. O planejamento, a ideia de lendas medievais que incluíam o Brasil a sudoeste da Irlanda nos mapas do fim da Idade Média $^{15}$ nos fazem crer que havia no mínimo uma intenção por trás dos atos da Coroa de Portugal.

É possível que os portugueses não soubessem realmente se aquelas terras existiam; entretanto, é quase certo que, no fim do século $X V$, já se tinha notícias concretas de terras no Atlântico Meridional; principalmente, porque Duarte Pacheco, a mando do Rei de Portugal, navegou o Caribe e costeou o litoral setentrional brasileiro relatando esta viagem ao rei.

\footnotetext{
${ }^{15}$ MARTIN, A. (2007:59) In: Brasil, Geopolítica e o Poder Mundial - o anti-Golbery.

A opinião de Gustavo Barroso parece bastante equilibrada quando conclui que houve uma intercorrência entre lenda e história, "madeira" e "terra", em função da semelhança de vocábulos. A pesquisa cartográfica realizada pelo historiador cearense permitiu-lhe dar um passo adiante, e reconhecer que a existência comprovada de antiga lenda celta, projetada em inúmeras cartas, impedia que se julgasse o nome Brasil como tendo derivado unicamente da madeira de tinturaria. $O$ que ele não poderia prever àquela altura, é que investigações subsequentes desequilibrariam as duas hipóteses, com nítida vantagem em favor da lenda irlandesa.
} 
O retorno à lenda de São Brandão nos faz notar como falta ainda muito caminho a percorrer para que se consiga distinguir com precisão, neste campo da toponímia, a lenda e a ciência; o sonho, a imaginação, e, porque não dizer o interesse; daquilo que se convencionou denominar de "realidade objetiva", sobretudo quando nos aprofundamos na busca das origens das civilizações, ou da característica essencial de cada cultura. (MARTIN, 2007:62)

Alguns historiadores contemporâneos aceitam a ideia de que a expansão global portuguesa foi um fenômeno absolutamente desprovido de qualquer planejamento mais orientado. Liderando esses pensadores, 0 historiador inglês C.R. Boxer estruturou todo seu estudo para desmontar a tese de que o Império Português se expandiu em cima de projeções em escala global. Segundo CURTO (2011), a produção de Boxer na década de 1960 é explicada pelo contexto da descolonização na África e seus matizes liberais conservadores que se colocavam contra o domínio colonial português na África. Para Boxer, o luso-tropicalismo e a teoria da descentralização e autonomia apareciam como a principal face da construção da ideologia colonial oficial. Este discurso do Estado Colonial português, aparentemente, pretendia esconder as tensas relações que a ditadura de Salazar promovia em suas colônias. Assim, o historiador inglês se distancia das teses dos historiadores republicanos nacionalistas como António Sérgio, Jaime Cortesão e Nilton Freixinho, este último brasileiro. Esses últimos eram a favor da tese que a formação de Portugal estaria nas atividades marítimas, no comércio, a pesca e etc.

A terra obedece a um regime patrimonial, sem obrigações de serviço de rei, não raro concedida com a expressa faculdade de aliená-la. O serviço militar prestado em favor do rei reveste-se da categoria de serviço público, mediante remuneração. Surge, na pessoa do príncipe, um órgão centralizador, dirigente, que conduz operações comerciais como suas. Nenhuma exploração industrial ou comercial está isenta de seu controle. Guarda para seu comando imediato os setores mais lucrativos, que concede, privilegia e autoriza a expansão do capitalismo comercial e que fará do Estado uma imensa empresa tráfico. A Coroa está em todos os monopólios que lhe pertencem; pimenta, paubrasil,escravos. A empresa, à medida que se expande, exige novos e maiores recursos para sustento da máquina administrativa da exploração comercial, daí a necessidade de uma dura política de rendas e de crescente dependência 
ao capitalismo internacional, nos empréstimos, contratos e compromissos (FREIXINHO, 1994: 20)

O luso-tropicalismo é a ideia de que o português soube se integrar, miscigenando-se nos locais em que estava e assim dominando as relações sociais. Tal ideia é rechaçada juntamente com a tese de Gilberto Freyre, que suaviza as relações sociais racistas dos portugueses. Para Boxer, as razões da expansão do império português foram: as cruzadas (cristianização), dominar as fontes de ouro e diamantes da Guiné e o monopólio das especiarias. E, para isto, o Império marítimo português criou um sistema social racial pautado em alianças locais nas quais os grupos étnicos eram classificados para determinadas atividades, visando sustentar a máquina deste império.

FREIXINHO (1994:22), entretanto, aponta que existe, em relação as Terras Americanas portuguesas, um significado estratégico para expansão global de Portugal e, por isso, a Coroa sempre reagirá quando da possibilidade de perder essas terras para outras potencias ultramarinas emergentes. Com a descoberta da rota para as Índias pelo Atlântico, Portugal, que tinha uma posição na antiga rota comercial do mediterrâneo para o mar do norte, passa a ser o país com a melhor posição para estabelecer uma ligação entre a Índia e a Europa, tendo o Brasil como uma paragem para os barcos comerciais e um território para sua expansão. "Nessa rota reside o elo que garante a sobrevivência de Portugal, que, através dela, oferece, nas praças de Flandres e de Antuérpia, os produtos adquiridos nos mercados africanos e asiáticos". (ibidem, 1994:22).

\section{Raízes históricas do meridionalismo: do Tratado de Alcáçovas-Toledo ao Tratado de Tordesilhas}

$\mathrm{Na}$ segunda metade do século $\mathrm{XV}$, a guerra de sucessão castelhana (1475-79) ocorrera tal como à Revolução de Avis. Entretanto, desta vez, D. Afonso V de Portugal casado com Joana Beltraneja, reconhecida como sucessora do Rei Henrique IV de Castela, reivindica o trono de Castela para si. Enquanto os castelhanos eram partidários de Isabel, meia irmã de Henrique IV, casada com Ferdinando de Aragão, apoiando-a como sucessora legítima da 
coroa do reino unido da Espanha. Esse episódio histórico é conhecido como a Guerra de Beltraneja e termina com Isabel de Castela sendo coroada juntamente com Ferdinando de Aragão, seu marido, recebendo o título de Reis Católicos e unindo as coroas de Castela e Aragão.

Ferdinando de Aragão e Isabel de Castela, cujo casamento criou o reino unido da Espanha, agiram de maneira muito semelhante a partir de cerca de 1480 . Ferdinando entrou com a arte e com um novo estilo, italiano, de política externa; e Isabel com a piedade e com os valores morais apreciados pelos espanhóis; mas ambos estavam igualmente decididos a forjar seus domínios num Stato, governado pela vontade pessoal de seus "reis católicos". (WATSON, 2004:234)

A batalha de Toro foi decisiva e foi o grande fracasso lusitano do século $\mathrm{XV}$, tanto que Afonso $\mathrm{V}$, símbolo de grandes conquistas além-mar no norte da África, abdica ao trono em favor de seu filho D. João II. A tentativa de unir as coroas por parte dos portugueses resultou no surgimento da Espanha como estado moderno acentuando ainda mais a rivalidade entre as coroas. Em 1479, Portugal e Espanha assinam o Tratado de Alcáçovas-Toledo (1479-80). Esse é reconhecidamente o embrião do Tratado de Tordesilhas (1494), no qual, pela primeira vez, o Oceano Atlântico é divido em duas regiões de influência e não em rotas comerciais; sofisticado para época que foi elaborado, são os primeiros passos da diplomacia moderna ${ }^{16}$.

Percebe-se que a arte da política do Stato de Poder, influência da península itálica, permeará as relações políticas importantes para 0 estabelecimento do nascimento do Estado Moderno. Assim, como a tentativa de concentrar poder na mão do rei traz a necessidade de não só desenvolver um exército nacional, mas como também, novas técnicas de guerra, que se somarão com novos inventos; é o caso mais específico do uso da pólvora no final do século XIV.

\footnotetext{
${ }^{16}$ MARTINS, O. Em "História de Portugal" (19a edição: 1987):

Afonso $V$ fora a França pedir o auxílio, porque o castelhano batera-o. Em 1474, Henrique IV de Castela, ao morrer, deixava por herdeira D. Joana, a beltraneja (assim os adultérios da mãe tinham denominado a filha), confiando o governo do reino ao vizinho de Portugal e pedindo-lhe que casasse com a sobrinha. Afonso $\mathrm{V}$ julgou que o reino de Castela era a nova África de sua velhice e pôs-se em campo para conquistar a coroa testada: conquistar, dizemos, porque os castelhanos invocam contra a beltraneja os mesmos argumentos que, um século antes, nós invocamos contra a mulher de D. João I, D. Beatriz. Castela oferecia o trono a Isabel, como nós o tínhamos dado ao mestre de Avis. (p.144).
} 
Como já havia sido comentada por Maquiavel em "O príncipe", era importante que um rei tivesse suas próprias forças para estabelecer seu Statos de Poder:

\begin{abstract}
Carlos VII, pai de Luís XI, tendo com sua fortuna e sua virtude libertado a França dos ingleses, conheceu essa necessidade de armar-se com forças próprias e organizou em seu reino, por forma regular, as armas de cavalaria e de infantaria. Mais tarde, o Rei Luís, seu filho, extinguiu a infantaria e começou a aliciar os suíços, erro esse que, seguido de outros tornou-se, como agora se vê, a razão dos perigos daquele reino. (MAQUIAVEL, 1998:81)
\end{abstract}

No Tratado de Alcáçovas (1479), a Coroa Portuguesa reconhecia os Reis Católicos como monarcas de Castela e renuncia a intervir na sucessão castelhana. Os problemas de sucessão estiveram intrinsicamente ligados a discussão do espaço de intervenção oceânica e Isabel reconhece o predomínio português no Atlântico Sul. $O$ tratado é feito pela demanda de resolver dois problemas: o de sucessão e o de intervenção oceânica. O Oceano Atlântico foi dividido por uma linha paralela a partir do extremo meridional do arquipélago das Canárias dividindo o mar oceano: ao norte para os espanhóis e ao sul para os portugueses. Resguardando-se as ilhas de Madeira e dos Açores - ao norte do paralelo - para os portugueses, e as Canarias e os reinos Africanos sobre o domínio de Castela - ao sul do paralelo - para os espanhóis. Assim como é firmado o trânsito livre para se chegar na área de influência respectiva.

Embora o Tratado de Alcáçovas-Toledo represente a vitória castelhana sobre as pretensões portuguesas, ela é, ao mesmo tempo, símbolo da hegemonia portuguesa no atlântico sul, pois se reconhece oficialmente que as terras do Atlântico Sul deveriam ser de domínio português.

Entretanto, as descobertas colombianas teriam um efeito desastroso para o acordo de Paz entre os reinos ibéricos, pois as terras encontradas por Cristóvão Colombo situavam-se ao sul do Tratado de Alcáçovas-Toledo. Paralelamente, as descobertas, as tensões entre os reinos de Portugal e Espanha aumentavam sempre que o papa Alexandre VI, aragonês de nascimento, emitia uma série de Bulas concedendo as novas descobertas ao Reino de Espanha; o traçado no sentido meridional de algumas delas - aparentemente recomendação feita pelo próprio Cristovam Colombo, 
que percebera que o traçado paralelo favorecia os portugueses - legitimavam as descobertas espanholas ${ }^{17}$.

Os portugueses insistem numa linha paralela que the dariam a possibilidade de dominar o Atlântico-Sul e consolidaria, de uma vez por todas, o seu predomínio sobre os castelhanos e das navegações ultramarinas, enquanto os espanhóis queriam legitimar as descobertas colombianas (1492) e assim propunham uma linha meridional de um polo ao outro.

\section{Partilha do Mundo entre Castelhanos e Portugueses (Tratado de Alcáçovas-Toledo)}

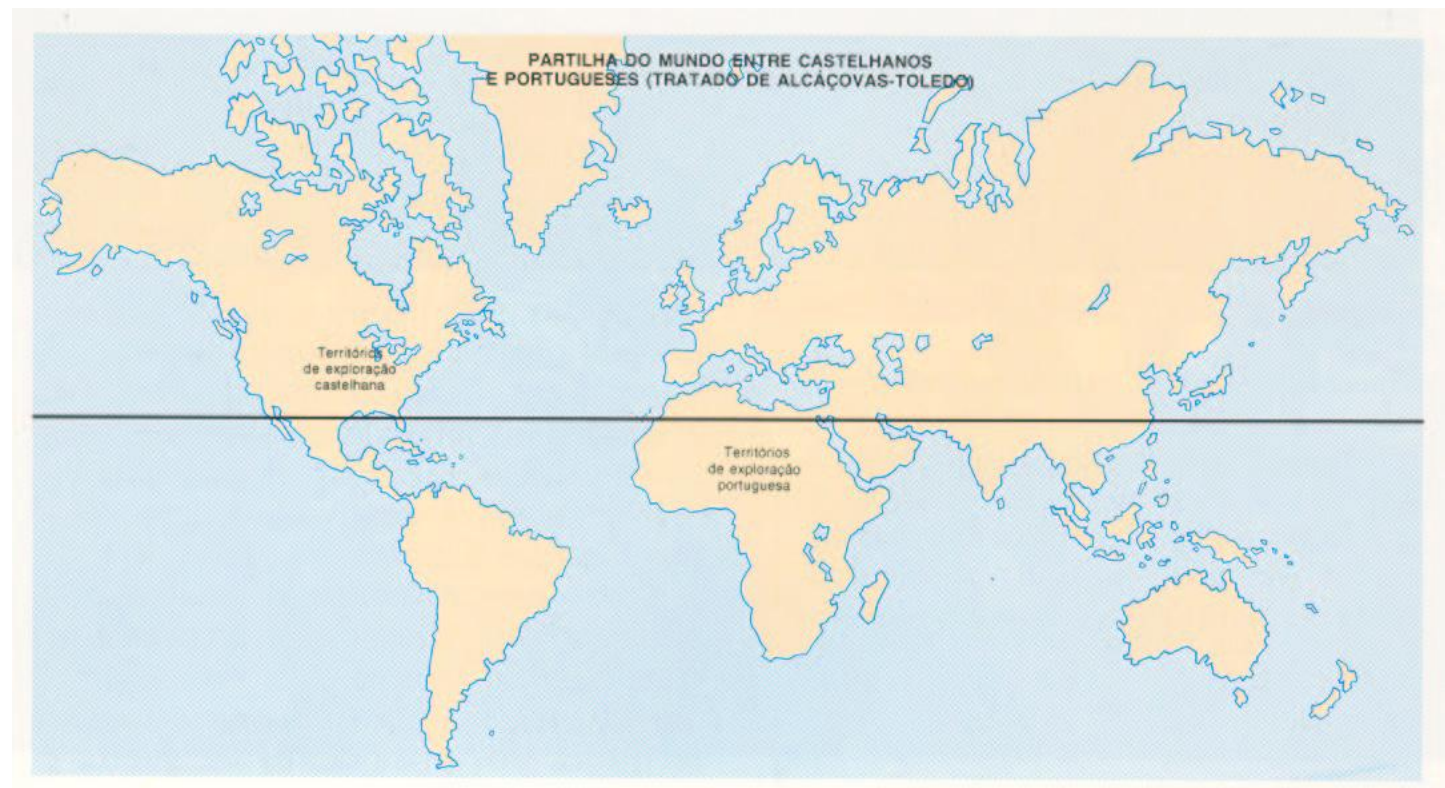

Figura 5 -Extraído em: http://www2.crb.ucp.pt/historia/abcedário/afonso5/tratado.htm (acesso em 09/04/2012)

Para evitar uma guerra entre os reinos ibéricos, foi elaborado o Tratado de Tordesilhas (1494), que deveria ser um acordo entre os dois estados sem a interferência papal e que resolveria às exigências de ambas as partes. O Tratado de Tordesilhas foi rigoroso o suficiente para resolver os

\footnotetext{
${ }^{17}$ CASTRO, T. Em: Do Infante a Tordesilhas - Sistemática Geopolítica. (1995: Revista IGHMB. Ano 55):

Para evitar o confronto entre os dois Reinos Cristãos, o Papa Alexandre VI entraria em cena. Tornava, inicialmente, o impasse ainda maior com sua Bula de 3 de maio de 1493. Extravasava neste documento, a sua origem espanhola, concedendo soberania plena aos "Reis Católicos" sobre todas as terras e ilhas desconhecidas antes da viagem de Colombo, para o Ocidente, no Mar-Oceano, e na direção da Índia, portanto no Oriente, desde que não pertencessem a nenhum monarca cristão. Esse rasgo de hispanidad seria imediatamente contornado com a imediata segunda Bula Inter Coetera, do dia 4 de maio de 1493, que já dividia o Mundo por um meridiano que passasse pelos arquipélagos dos Açores ou Cabo Verde - o Ocidente seria espanhol e o oriente português.
} 
problemas imediatos e, ao mesmo tempo, ambíguo para adaptar as situações que não eram previstas. Portanto, podemos afirmar que o Tratado de Tordesilhas representa uma vitória espanhola, pois legitimou suas descobertas no caribe e nas Américas. Ao mesmo tempo representa uma vitória portuguesa que tinha $o$ interesse no comércio de especiarias e na rota comercial do Atlântico.

O Tratado de Tordesilhas já possui dispositivos que o colocam como o marco inicial da diplomacia moderna e uma primeira ruptura com os padrões medievais. Esse acordo procurava regulamentar a disputa entre as coroas ibéricas pelos mares, ilhas e terras descobertas e por descobrir. Estabelecia uma linha meridional situada a 370 léguas da llha de Cabo Verde. Linha meridional foi uma exigência espanhola a posição da linha foi uma exigência de D. João II, assim garantindo a presença portuguesa no novo continente. As monarquias lbéricas retomavam alguns princípios de Alcáçovas como livre trânsito entre as regiões de domínio marítimo e o princípio Mare Clausum, dispositivo que garantia os domínios dos reinos ibéricos do assédio de outros potentados europeus.

desde meados do século $\mathrm{XV}$, em sucessivas Bulas papais, a Coroa Portuguesa e a Ordem de Cristo obtiveram o reconhecimento de sua primazia sobre todas as terras conquistadas ou a conquistar, situadas ao sul do Cabo Bojador e Grande Canária, de modo que foi precisamente com base nelas que El Rei D. João II considerou, como provavelmente portuguesas, as novas terras descobertas por Colombo, o que fez propor a utilização de uma paralela saindo das Canárias como linha demarcatória delimitando ambos os domínios (CARVALHO, 1998:2 apud MARTIN, 2010:98).

MARTIN (2004:30) destaca o fato de Portugal ter apenas 1/8 da população espanhola e mesmo assim ter uma projeção mais global do que a Espanha, isso porque os conhecimentos náuticos, geográficos e militares portugueses eram, ao que tudo indica, superiores ao de qualquer nação da época. "Eles foram os primeiros a fabricar navios adaptados à navegação oceânica - as caravelas -, como também inventaram o alinhamento de canhões na lateral do navio". (Ibidem, 2004: 30). Com esse conjunto de elementos técnicos e militares, os portugueses puderam navegar em oceano 
aberto e serem senhores do Atlântico Sul, do Índico e Pacífico na passagem do século XV e XVI.

\begin{abstract}
Eles foram, afinal, os principais idealizadores do Tratado de Tordesilhas, o português constitui-se na primeira língua franca mundial, o pavilhão luso foi o primeiro a tremular simultaneamente em quatro continentes, e o escudo foi a primeira moeda conversível em escala global. Sem risco de cair em exageros, pode-se dizer com segurança, que Portugal deu início ao processo que hoje denominamos de globalização. (MARTIN, 2004:29)
\end{abstract}

O acordo de Tordesilhas representa a consolidação de um processo de mundialização que será impulsionada pelos portugueses. De acordo com MARTIN (2004), Portugal é o país que inventa a globalização e que o Tratado de Tordesilhas é a ratificação deste processo. Assim se tem, que a Geografia Militar em forma embrionária se fez da cartografia naval portuguesa e foi ampliada pelas experiências de suas lutas no norte da África, América do Sul, no Périplo Africano, Índia chegando até o Japão. Sua parte do tratado era o mundo e os espanhóis ficaram com a maior parte das Américas.

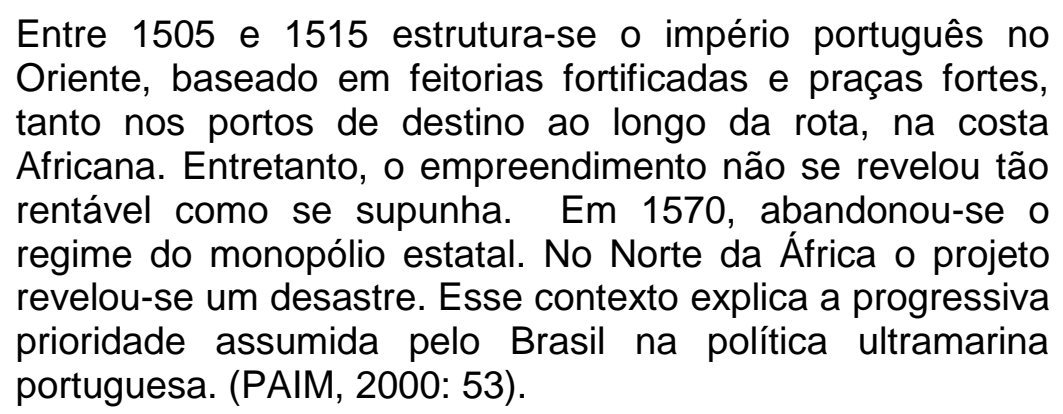

As inovações portuguesas na Geografia Militar, embora fossem adaptações de outras nações, foram muito importantes e, certamente, irão influenciar o pensamento sobre a estratégia e a tática nas suas colônias. Foi exatamente a coincidência do esgotamento das especiarias e do avanço francês na exploração da madeira tintorial que provocaram em Portugal a necessidade de efetivar a ocupação e estabelecer uma defesa mais adequada de seu território americano, "era agravado pelo enfraquecimento do poder econômico de Portugal, em decorrência da queda do comércio internacional com produtos da Índia e da África" (FREIXINHO, 1994: 28) 
Neste contexto, a opção de Lisboa foi deslocar para o Brasil a prioridade de sua política ultramarina. Aqui passam os lusos a concentrar todo o esforço do Estado de Aviz. Desde então, a Colônia Brasileira no Atlântico Sul torna-se o ponto de sustentação da sobrevivência política e econômica de 'Portugal, o que perdurou trezentos anos. (FREIXINHO, 1994:29)

No final da década de 40 do século $X V I$, em razão de ter o Brasil como centro de suas ações políticas, a coroa portuguesa instala o Governo Geral do País-Colônia e Tomé de Souza se torna o primeiro Governador-Geral do Brasil. D. João III lhe entrega o regimento que define poderes e normatiza a ação política do governo. "É licito dizer que o Regimento de dezembro de 1548, que instituiu o Governo-Geral do País-Colonia,constituiu verdadeira Carta Magna do Brasil e sua primeira constituição" (FREIXINHO, 1994:30). A integridade territorial e o centralismo do governo no Brasil tem o embrião no regimento do Governo Geral de dezembro de 1548, aí "vamos encontrar a origem mais remota, em termos instituicionais, da unidade do Brasil e de uma das tendências que prevalecem até os dias de hoje: o centralismo" (ibidem, 1994:30).

\begin{abstract}
Nesse sentido, o Governador-Geral do Brasil foi investido do papel de verdadeiro inspetor e de coordenador-diretor de todas as atividades atribuídas aos Capitães-Gerais das Capitanias. Contudo, a preocupação dominante era o povoamento e a defesa contra o gentio e contra o estrangeiro, bem como a vigilância do litoral (FREIXINHO, 1994: 29).
\end{abstract}

A institucionalização e centralização do poder teve como justificativa a ameaça de potências emergentes. Em 1554, a França tenta a fundação de uma colônia na América Meridional. "A História registra o intento dos franceses, desde de 1503, para fixação de núcleos de ocupação em vários pontos da Costa Brasileira". (FREIXINHO, 1994: 32). Foi o aprofundamento da institucionalização e da centralização da política de defesa que permitiu aos portugueses expulsar os franceses que não tinham apoio total de seu governo por serem huguenotes descontentes com o seu governo e tinham uma aliança indígena que proporcionou um tempo maior no território, mas que não garantiu a sua permanência. 
No entanto, a tentativa da France Antartique, com seus colonos, comerciantes, militares e administradores, tendo os indígenas como aliados, teve um potencial que as demais não possuíam: a mística religiosa dos franceses huguenotes, que pretendiam aqui instalar um país livre da repressão os calvinistas sofriam na França, desde a década de 1550. Aqui instalados um território livre para acolher o fluxo migratório dos franceses descontentes com a conjuntura religiosa de seu país de origem. (FREIXINHO, 1994: 32)

A questão cultural-ideológica foi outro ponto que trouxe coesão a ação do Governo-Geral e foi trazida pela Companhia de Jesus. "Os jesuítas portugueses sabiam que, no caso, não se trata exclusivamente de uma guerra contra o invasor francês, mas sim - e, sobretudo - contra o "herege calvinista" (FREIXINHO, 1994:33). Foi o Governador-Geral Mem de Sá que assumiu pessoalmente a conduta das operações, entre 1560-67 várias expedições foram empreendidas contra os invasores franceses instalados e fortificados na Baía de Guanabara, quando os jesuítas conseguem convencer os índios a mudarem de lado e sem o apoio da metrópole, a França Antártica chega ao fim em 1567.

Estavam preservadas a integridade territorial e a unidade
cultural-religiosa do Estado do Brasil no Sul do País.
Todavia, em Lisboa, os experimentados planejadores
responsáveis pela segurança da Colônia na América
Meridional reconheciam que a ameaça, embora debelada,
poderia ressurgir no Rio de Janeiro ou em outros pontos do
litoral. Urgia, pois, tomar medidas administrativas e militares
para impedir que isso viesse a acontecer. (FREIXINHO,
1994:33)

A Geografia Militar nos Estados Ibéricos sofreu influência de duas importantes rivalidades geopolíticas: entre Portugal e Espanha, tanto em terra quanto pelo mar, e entre Inglaterra e França, cavalaria francesa versus infantaria inglesa. Os elementos técnicos que estão na raiz da formação da Geografia Militar são: a cartografia, esta será trazida dos teóricos do mediterrâneo acrescida ao empirismo da geografia árabe; e a pólvora, esta revolucionará a disposição tática, sobretudo com o desenvolvimento da artilharia que, quando acoplada aos navios, irá ser muito efetiva contra as fortificações marítimas e portuárias. 
E, por fim, o elemento ideológico que é o Stato de Poder, aumentar o poder concentrando-o na mão do Rei, que será tão forte se suas forças militares forem fortes e bem organizadas. Essa oposição geral, Portugal $X$ Espanha, sofrerá uma transformação marcante, quando problemas na sucessão do poder da coroa portuguesa empurram a esfera de poder marítimo para coroa castelhana, causando uma crise na Ordem das Relações Internacionais. 


\title{
CAPÍTULO 2 - A UNIÃO IBÉRICA E O "DESTINO MANISFESTO" LUSO-BRASILEIRO NA AMÉRICA DO SUL: O ALVORECER DA GEOGRAFIA MILITAR NO BRASIL.
}

\section{Introdução}

O Tratado de Tordesilhas representa o auge do poderio português que, ao longo do século $\mathrm{XVI}$, vai se esvaindo até a trágica morte de $\mathrm{D}$. Sebastião, em 1578. Ao mesmo tempo, este acordo representa o início das pretensões hegemônicas da Espanha, que terá seu auge com a União Ibérica. "O monarca português não deixou herdeiros, o que facilitou as pretensões de Filipe II da Espanha de unificar a península sob seu comando". (MARTIN, 2004:31).

Segundo PAULA CIDADE, em "Síntese de três séculos de literatura militar brasileira", de 1959, não se pode entender um pensamento militar de um determinado momento sem que se tenha a concepção da política em que ele está inserido, pois o primeiro é intrinsecamente atrelado ao segundo. A cultura é fator essencial na prática de como os povos se apropriam e transformam o próprio espaço. No caso brasileiro, a rivalidade entre portugueses e espanhóis pauta a política de ambos os lados - pelo menos até 1580, quando ocorre a União Ibérica - assim como a política hostil aos povos autóctones.

\begin{abstract}
Um pensamento militar é sempre o reflexo de um pensamento político, que ao amadurecer vai se transformando com o decorrer do tempo. Os seus elementos básicos são as condições geográficas de cada país, as componentes étnicas de seu povo, as quais acarretam peculiaridades mentais, os fatores econômicos que correspondem a necessidades vitais e a ambições de riquezas, a vizinhança de povos irrequietos e historicamente hostis, os recursos materiais e a mão de obra para a guerra, mais ou menos abundante. (PAULA CIDADE, 1959: 2).
\end{abstract}

Doravante a 1580, percebem-se pelo menos três movimentos distintos na política territorial da América do Sul: a defesa do catolicismo contra o protestantismo expressa na guerra contra os holandeses; a expansão luso- 
brasileira na bacia amazônica na qual os principais rivais são a França, Inglaterra e Holanda, a luta ligada à rivalidade das grandes famílias reais Habsburgos versus Bourbons - no caso da luta contra a França -, da tentativa jesuíta de estabelecer a Contra-Reforma e da expansão luso-brasileira - nesse caso estamos falando da luta contra os Ingleses e Holandeses na Bacia Amazônica e da aliança luso-espanhola; e, por fim, a expansão portuguesa na margem esquerda da Bacia do Prata, que marcará a rivalidade Ibérica $^{18}$ na América Platina do século XVIII. "Esses três acontecimentos históricos mais ou menos se equivalem, como fontes de brasilidade e como expressão do espírito político-militar que os ditou" (PAULA CIDADE: 1959: 2).

Curioso é notar a sincronização da cessação das hostilidades francesas no Novo Mundo e a aliança entre França e Espanha no Velho Mundo, ambas em 1615, o que sobrestou em parte os ataques indígenas, que impediam a conquista do Maranhão. Essa Trégua passageira durou pouco porém. Houve desentendimentos entre espanhóis e portugueses no comando desta conquista, e, assim, complicou-se ainda mais a situação, pois deu margem a novo tipo de conflito que já se vinha esboçando desde a conquista da Paraíba, ou seja, o conflito entre interesses portugueses e espanhóis no Brasil, durante o período dos 3 Filipes de Espanha, sendo que o conflito entre interesses espanhóis e portugueses no Prata era um fato. (HOLANDA, 1989:183).

Onde observamos o interesse comum ibérico, temos uma expansão do território português na América do Sul - são acontecimentos que ocorrem da União Ibérica (1580) até a restauração da família real portuguesa (Bragança) no Poder e a derrota espanhola na Guerra dos Trinta Anos (1648). Já onde os interesses eram divergentes entre os estados lbéricos, as possessões portuguesas são afuniladas devido às intensas disputas - dando para o Brasil, após aos tratados de 1750 e 1777, a forma territorial que se estabeleceu desde então, com exceção do território do Acre.

\footnotetext{
${ }^{18}$ MARTIN, em Geopolítica e poder mundial, (2004: 31): A posição da Espanha nos anos seguintes foi a de um "Estado perturbador", que tentou atrair para si, a totalidade do poder mundial. As potências em ascensão - Holanda, França e Inglaterra - uniram-se contra Filipe II, que além do mais via-se como protetor da religião católica contra a reforma protestante, e de toda a Europa contra o Império Turco Otomano. Com tantos inimigos não é de estranhar que com tempo, a capacidade espanhola de ordenar o mundo fosse desgastando, até vir a esgotarse completamente na "Guerra dos 30 anos", conflito que ensanguentou a Europa entre os anos de 1618 e 1648 , e modificou o mapa do mundo.
} 
As lutas que se travaram ao norte do Brasil entre $1624 \mathrm{e}$ 1654, as quais passaram à história sob nome de guerra holandesa, revelam, como é natural, apenas o pensamento militar português, no caso concordante com o pensamento militar espanhol. No entanto, pode-se ver aí um passo importante para o advento do pensamento militar brasileiro. Não se pode dizer o mesmo das lutas travadas quase um século antes, quando se cuidou de expulsar os franceses do Rio de Janeiro (1567). (PAULA CIDADE, 1959: 3).

PAULA CIDADE (1959) chama a atenção para o fato de que a literatura militar no Brasil ocorre a partir dos embates do século XVII e, assim, como BARROSO (1938), descarta as lutas para expulsar os franceses do Rio de Janeiro em 1567 por não ter produzido uma bibliografia vultuosa. Entretanto, o autor nos chama a atenção para a compreensão de que a guerra holandesa, assim como a disputa Ibérica na Bacia do rio da Prata, irão produzir uma literatura militar e são passíveis de ser considerados como os ancestrais da Geografia Militar no Brasil.

\begin{abstract}
A primeira tropa mais ou menos regular que teve o Brasil, vinda de Portugal, foi composta pelos 600 voluntários desembarcados com o governador geral Tomé de Souza, na Bahia, em 1549. Sobre sua organização, bem como sobre a dos soldados que combateram os franceses no Rio de Janeiro às ordens dos Sás, ao certo nada se sabe. Assim no século XVI, da divisão do Brasil em capitanias até as invasões estrangeiras não se conhecem documentos seguros de nossa vida militar. (BARROSO, 1938: 11)
\end{abstract}

Dos séculos XVII e XVIII, os relatos que seguem podem ser considerados os mais influentes dentro da literatura militar além de contribuírem para uma elucidação de uma Geografia Militar no Brasil nos séculos XVI, XVII e XVIII:

1) Sobre a guerra holandesa: "O Valeroso Lucidenio e Triunfo da Liberdade" do Frei Manuel Calado de 1648; "O Inventário das Armas e Petrechos Bélicos, que os holandeses deixaram em Pernambuco e dos Prédios Edificados ou reparados até 1654", da Imprensa Oficial, Recife 1940; "Os Anais Históricos do Estado do Maranhão" de Bernardo Pereira Berredo teve sua primeira edição em 1749. 
2) Sobre a guerra na Bacia do Rio da Prata: "A História Topográfica e Bélica da Nova Colônia do Sacramento por Simão Pereira Sá de 1737"; "O Exame de Artilheiros, que compreende aritmética, geometria e artilharia" por Tenente-de-Mestre-de-Campo-General José Fernandes Pinto Alpoym de 1744 e "O Exame de Bombeiros" de 1748 do mesmo autor; "Capitão da Infantaria Portuguez" de André Ribeiro Coutinho de 1751; O Regulamento de Conde Lippe de 1763 e o "Regulamento para o Exercício e Disciplina dos Regulamentos para o Exército de $\mathrm{S}$. Majestade Fidelíssima" do mesmo autor.

3) Sobre os relatos das lutas e ocupações da Amazônia, temos: As Crônicas de Carvajal viagens de Francisco Orellana do século $\mathrm{XVI}^{19}$; Novo Descobrimento do Grande Rio Amazonas do Pe. Cristóbal de Acuña do século XVII (1641) relatos da descida da expedição lendária do Capitão Pedro Teixeira; O inglês O Bernard O'Brien que a serviço do Sir Roger North relata a tentativa inglesa de se estabelecer no Maranhão do século $\mathrm{XVI}$.

Desta forma, estabelecidas as balizes desta primeira parte da análise, se realizará um estudo destas três correntes expansionistas, que irão se transformar nas bases para o surgimento de um pensamento político-militar no Brasil; expansão amazônica luso-brasileira, a luta contra os holandeses e a busca pela hegemonia platina. Esses três movimentos produzirão uma análise militar do espaço territorial brasileiro que está sendo construído à medida que os fatos se desenrolam.

\footnotetext{
${ }^{19}$ ESTEVES (1994:12). In: Novo Descobrimento do Rio Amazonas:

Atualmente são conhecidas duas versões da crônica escrita por Carvajal (...). Uma das versões conhecidas é aquela incluída por Gonzalo Fernandez de Oviedo na terceira parte de sua História Natural de Las Indias, terminada por volta de 1559, mas inédita até 1855 (...). Da outra versão da crônica de Orellana existem duas cópias. Uma delas, completa, pertencente ao Duque de T'Serclaes, foi publicada em 1894 pelo historiador chileno José Toribio Medina (...)A segunda cópia da crônica de Carvajal, incompleta, pertencente à Colección Muñoz da Real Academia de História de Madrid e foi utilizada na edição feita por Jorge Hernández Millares, em 1955, no México, tendo o texto sido completado pela edição de Medina do manuscrito de T'Serclaes. (...)Apesar de ficar inédita por quatro séculos, a Relação de Carvajal foi muito divulgada na época. Em janeiro de 1543, o próprio Oviedo mandou para o cardeal Bembo uma carta com o relato do descobrimento, publicada em 1555, na Itália. A partir de então, vários cronistas, se referem à viagem de Orellana: Lopez de Gomara, Agustín de Zárate, Inca Garcilaso de la Veja, Cieza de León e Antonio de Herrera.
} 


\section{União Ibérica versus Potências Emergentes (França, Inglaterra e Holanda).}

Ao longo do século $X V I$, Portugal quase não desrespeita o Tratado de Tordesilhas e não se aventura em explorações pelos interiores amazônicos. Necessário é ressaltar que era muito difícil até o século XVIII estabelecer onde exatamente ficava a linha divisória. Fica a incumbência, principalmente da Espanha, em se atirar à descoberta dos segredos do rio Amazonas. França, Inglaterra e Holanda, no mesmo período, também estavam reconhecendo quais os melhores pontos estratégicos para futuros empreendimentos, segundo Lysias Rodrigues (1978):

Presumindo estar o Eldorado na região amazônica nada
mais natural que franceses, ingleses e holandeses,
tratassem de procurá-la e conquistá-la, para tanto
estabelecendo colônias que servissem de bases às intensas
explorações sistemáticas que projetavam realizar em
seguida.

Em 1500, foi realizada a grande expedição do capitão espanhol Vicente Pizon, saindo das costas Pernambucanas em direção ao norte até a foz do grande rio (chamado por Pizon de Grande Mar Doce), depois navegando até a região das cordilheiras andinas.

O capitão Francisco Orellana foi o primeiro a reconhecer o rio Amazonas de sua nascente até a foz, numa excursão que demorou quase três anos. Sua viagem começa junto à grande expedição de seu meio parente Gonzalo Pizarro, que tinha como objetivo conquistar o "País da Canela". Com mais de duzentos espanhóis e quatro mil índios, a expedição partiu de Quito em fevereiro de 1540 (ESTEVES, 1994:9).

Logo se percebeu que a exploração da canela amazônica era inviável pela pouca concentração da árvore na floresta e pela baixa qualidade, quando comparada a canela da Índia. Depois de mais de um ano de viagem, Pizarro ordenou Francisco Orellana que descesse o rio em busca de alimentos e que voltasse em um ponto de encontro na confluência do rio que navegava, muito provavelmente na bacia do Napo.

Orellana seguiu o rio e não encontrando alimento, não regressou. Pizzarro, depois de esperar, resolveu subir as cordilheiras e chega a Quito 
depois de uma dura viagem com alguns poucos homens em 1542 "mais ou menos a mesma época em que o grupo de Orellana entrava no Oceano Atlântico" (ESTEVES: 1994:9).

Francisco Orellana quem nomeia o rio se referindo a uma antiga lenda europeia de uma tribo de cavaleiras apenas formada por mulheres conhecidas como Amazonas. Essas fantasiosas descrições aparecem nas narrações do Frei dominicano Gaspar de Carvajal, participante da expedição de Orellana, e que se torna um mistificador da lenda das amazonas como se segue em suas próprias descrições: "são alvas e brancas, usando cabelo comprido; pernas e braços bastante desenvolvidos andam nuas em pelo e dissimulando o seu sexo, com seus arcos e flechas nas mãos, fazendo tanta guerra como dez homens" (CARVAJAL apud MATOS, 1980:21). A Coroa portuguesa inicia suas expedições no grande rio, apenas um século depois dos espanhóis.

As aventuras desta viagem foram narradas por um de seus participantes, o dominicano Gaspar de Carvajal numa famosa Relação. Nela, o cronista, preocupado em mostrar as privações da jornada, coloca poucos elementos objetivos da geografia da região por onde passa e de seus habitantes. É difícil identificar os afluentes do rio ou localizar exatamente as tribos referidas. Embora, deva-se lê-lo com cuidado, o fantasioso relato do dominicano encerra as primeiras informações conhecidas de como viviam os nativos da região e quais foram suas reações diante dos estranhos que chegavam. Parece que Orellana era um homem inteligente, pacífico e preocupado em conhecer a língua dos índios. Isso facilitou os primeiros contatos, evitando muitos incidentes. As margens do rio eram densamente povoadas, com aldeias atingindo várias léguas de extensão, algumas das quais eram bem construídas, com vias longas, amplos ancoradouros e muitos barcos. (ESTEVES, 1994:10).

É bom relembrarmos que, nos primeiros lustros do século XVI, "Casa de Avis" tinha seus interesses voltados para as rotas comerciais marítimas e ambicionava o monopólio das especiarias da Índia. O processo de colonização ainda engatinhava na Ilha Brasil, e seu principal objetivo para a nova terra era a exploração de pau-brasil, visto que os metais preciosos ainda não haviam sido achados, como nas colônias espanholas da América do Sul. 
Porém, ao final do século $\mathrm{XVI}$, a situação era muito diferente. A extração do pau-brasil passava por uma crise e o comércio das especiarias também. Todavia, o processo de colonização já estava instalado: cidades já haviam sido criadas e a cana-de-açúcar já começava a ser plantada. O território colonial já estava incluído na economia do mundo, ou seja, toda a sua organização deveria ser em função das exigências do mercado internacional.

O Maranhão representou, neste período, parte de uma política estratégica dos Governos espanhóis de Filipe II e Filipe III para a defesa da Bacia Amazônica. Embora território tenha sido estipulado como 'capitania donatária' desde 1535 pelo rei português, D. João III, com a intenção de proteger a retaguarda atlântica do projeto colonial português, a imprecisão do meridiano de Tordesilhas colocava a região na intersecção entre o "Estado Brasílico" e o Vice-Reino do Peru, como fora cartografado por Arnoldus Fiorentinus no fim do século XVI (ver mapa Figura 3$)^{20}$.

a própria conquista do Maranhão se vê favorecida por uma política de ocupação produtivo-defensiva da faixa equatorial do Atlântico, empreendida entre os governos de Felipe II e Felipe III, com objetivo de reforçar os vínculos comerciais, políticos e militares entre as partes do império, de modo a organizar melhor a defesa contra o assédio de outras nações europeias. (CARDOSO, 2011:322)

É justamente esta intersecção que será alvo de disputas de todas as potências europeias: disputa ibérica, pelo menos até a União das Coroas; e das potências emergentes do período, como Inglaterra, Holanda e França.

O perigo para a política de defesa habsburguesa na América do Sul era bem nítido. Segundo CARDOSO (2011), a documentação hispanolusitana é bem clara quando define e classifica o grau de perigo que cada potência europeia representava na América Meridional: "invasores" (franceses), piratas e traficantes (ingleses e irlandeses), "rebeldes" (holandeses) e "aventureiros" (italianos). "Para as autoridades hispano-lusas, todas essas

\footnotetext{
${ }^{20}$ CARDOSO (2011). In A conquista do Maranhão e as disputas atlânticas na geopolítica da União Ibérica.

Originalmente o Maranhão faria parte de uma tríplice seção de terras que deveria ser administrada por João de Barros, famoso historiador da Índia portuguesa, Ayres da Cunha, antigo capitão-mor de Malaca, e ainda Fernando Álvares de Andrade. Apesar de algumas tentativas de ocupação, organizadas por esses donatários, o Maranhão permanecerá como região virtualmente desconhecida até a época de Felipe III (1598-1621).
} 
categorias tinham seu nível específico de perigo, de acordo com certas circunstâncias internacionais" (Ibidem, 2011:322).

\section{Divisão Política da América do Sul século XVI (Arnoldus Fiorentinus)}

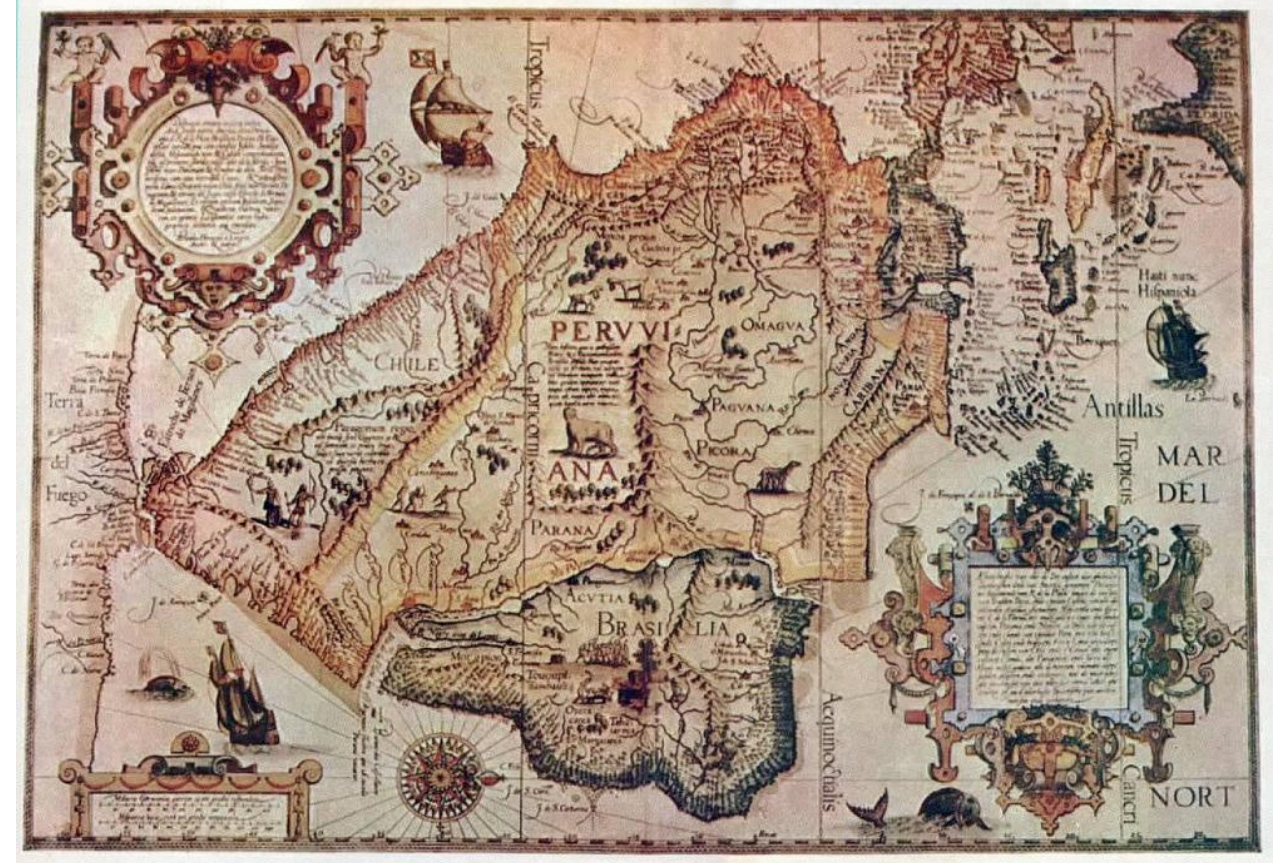

Figura 6 - Extraído de http://www.novomilenio.inf.br/santos/mapa63g.htm\#outro (acesso em 18 de junho de 2012).

Os ingleses e irlandeses não preocupavam de maneira significativa os hipano-lusitanos como os franceses "invasores" e os holandeses "rebeldes"; isto porque sua atuação na região do Maranhão buscava o lucro rápido e não um projeto colonial grandioso, como nos outros casos.

Segundo CARDOSO (2011:323), o capitão John Ley teria atingido o Baixo Amazonas em 1598, muito influenciado pela obra de Sir Walter Raleigh "The Discovery of the Large, Rich, and Beautiful Empire of Guiana" de 1595, chegando até o Xingu. Em 1609, Sir Thomas Roe saia de Londres em busca da cidade dourada de Manoa, mais uma viagem influenciada pela obra de Sir Raleigh - o próprio "ajudou a financiar esta última expedição, que contaria com um navio de 200 toneladas e 124 marinheiros, e que teria conseguido subir mais de 320 quilômetros pelo Amazonas" (Ibidem, 2011:323).

Em 1620, a expedição do capitão Roger North tentou construir uma companhia de comércio que tinha por objetivo a exploração de canela e 
tabaco e outros produtos tropicais; o projeto contava apenas com 120 homens ingleses e irlandeses, entre eles o irlandês Bernard O'Brien, que escreveu relatos de suas aventuras pela Bacia Amazônica. North voltou para Inglaterra, deixando ao encargo de O'Brien o projeto colonial. Fundou uma feitoria a 250 milhas a montante do rio Amazonas, mas foi atacado pelos portugueses, "anos mais tarde. O'Brien fugiu com um grupo indígena para o interior. Nesta viagem, ele diz ter encontrado a rainha das amazonas, com quem teria feito negócios". (ESTEVES, 1994:16).

Muito provavelmente, O'Brien conseguiu chegar até os rios Trombetas e Suriname. Esses projetos ingleses aparentemente esparsos na Bacia Amazônica "estariam mais tarde associados à criação da Guiana Company, em Londres (1627), que inicia projetos mais organizados envolvendo o Maranhão" (CARDOSO, 2011:323). Ingleses e irlandeses criaram feitorias na costa do Amapá, llha de Marajó e no baixo Amazonas. Mesmo assim, o projeto anglo-irlandês era muito mais direcionado à criação de entrepostos comerciais e feitorias do que promover uma concorrência com a Coroa dos Habsburgos.

Os "invasores" franceses, em resposta à tentativa de dominação habsburguesa (União Ibérica 1580), resolvem realizar um empreendimento colonial no litoral setentrional Atlântico da América do Sul, a França Equinocial. Tal empreendimento, onde hoje é o estado do Maranhão, pretendia duas coisas ao mesmo tempo: a extensão do poder francês no continente sulamericano e o domínio da foz amazônica, importante ponto estratégico sulamericano.

Já no final do século XVI, as forças francas já travavam batalhas com a intenção de construir fortes na costa norte da Capitania de Pernambuco nos atuais Estados da Paraíba e do Rio Grande do Norte. No dia 15 de agosto de 1597, treze navios franceses bombardearam durante sete dias o forte que protegia Cabedelo. Desta forma, as forças de defesa repeliram o Ataque do Comandante Miffaut, que seguiu para o norte. O navegador francês Charles De Vaux, que havia estado perdido junto aos tupinambás, convence os monarcas franceses a realizarem um projeto colonial na América Portuguesa. "Em 1604, os franceses já iniciam atividades de exploração na região da atual Guiana 
Francesa, liderados pelo general Daniel de La Touche, o mesmo militar que liderou a ocupação do Maranhão em 1612". (CARDOSO, 2011:326).

Os franceses começavam a estabelecer mais influência na região equatorial. Entretanto, a França, internamente, passava por uma crise entorno da sucessão ao trono ${ }^{21}$. Então não pode enviar grande número de tropas e dar apoio necessário ao Sr. La Ravardière (Daniel de La Touche).

Senhor La Ravardière, que já havia andado pelo litoral da Guiana, em viagem de exploração. Deveu-se a isso a concessão que ele obteve, em 1610, para construir uma fortificação que servisse de reduto ao sul da linha equinocial (LYRA TAVARES, 1979:89).

A fácil penetração dos franceses em território português deveu-se muito à aliança que foi costurada junto à tribo dos Tupinambás, fato que possibilitou prolongar seu projeto, que poucos anos mais tarde sofreria com a pressão luso-brasileira - e "era preciso contar com a aliança dos Tupinambás (...) o colonizador francês incutia no espírito dos Tupinambás a ideia de que os portugueses eram seus inimigos naturais" (LYRA TAVARES, 1979:93). O relacionamento entre franceses e indígenas era tão forte que nas palavras de Araújo Jorge, em seu livro O Brasil e a França do Século XVI, "a qualidade de francês é aqui uma espécie de passaporte" (ARAUJO JORGE apud RODRIGUES, 1978:54). E não nos esqueçamos do conhecido caso de Hans Staden, que teve sua vida salva por alegar ter essa nacionalidade, mesmo sendo de origem germânica.

Com tal aliança, os franceses começaram a realização de expedições rumo ao interior do território português por meio da foz do Amazonas, Podemos dizer que foram os franceses os primeiros a navegar 0 Tocantins da foz em direção a montante, quando 'monsieur' de Baut avista a serra dos Pacajás, "são elevações que formam a cachoeira Itaboca", sob o comando de La Blanjartier enviado por La Ravardière para uma expedição de reconhecimento, adentrando pela primeira vez a foz do rio Tocantins. "Isto significa, portanto, que o Tocantins foi descoberto por Mr. de La Blanjartier pela

\footnotetext{
${ }^{21}$ LYRA TAVARES (1979:90). In: Brasil e França: ao longo de 5 séculos

Encontrava-se, então, o governo da França sob a regência de Maria de Medici, reconhecida pelo parlamento. Mas La Ravardière conseguiu, mesmo assim obter a autorização da Regente para organizar a expedição colonizadora.
} 
foz, que por ele subiu no mínimo até à cachoeira Itaboca, em 1610." (RODRIGUES, 1978: 61).

Mais tarde, seguiram novas investidas dos franceses no rio Tocantins, mais acima. Em 18 de julho de 1613, partiu de São Luis do Maranhão uma expedição chefiada por La Ravardière, com 40 soldados, 10 marinheiros e 20 chefes indígenas. A rápida investida francesa ao rio Tocantins chegou à confluência com o Araguaia em expedição liderada pelo fidalgo La Planque, que depois de nove meses de viagem pelo rio Tocantins não poderia voltar para São Luís, pois os portugueses haviam tomado a posse do forte de São Luís. La Planque fica refugiado entre os índios Tupinambás por, aproximadamente, treze anos. (PRADO apud BARROS DA SILVA, 1997:28).

O projeto de colonização francesa era inadmissível para Filipe III, herdeiro do Império habsburguês ${ }^{22}$, que via na intenção da França uma grande ameaça aos seus extensos domínios. Juntamente com autoridades lusobrasileiras, era imperativo que as terras voltassem ao julgo do poderoso monarca.

\footnotetext{
E não tardariam as providências para expulsar os franceses do Maranhão, tendo como base de partida o Forte de Nossa Senhora do Rosário, baluarte implantado pelos portugueses no litoral cearense, em ponto mais avançado no rumo do Maranhão" (LYRA TAVARES, 1979: 97).
}

A primeira expedição luso-brasileira que foi organizada pelo Governador Geral Gaspar Dutra de Souza em 1614 para reconquistar o território perdido, foi comandada pelo Sargento-Mor Diogo de Campos Morena com aproximadamente um efetivo de tropas três vezes maior do que as tropas de defesa de La Ravardière.

Saíram de Pernambuco por via marítima e depois de algumas precipitadas investidas contra os franceses, instalaram-se em Guaxenduba, que oferecia excelentes condições estratégicas. Com guarnição melhor cercaram, pouco tempo depois, o forte de São Luís "A guerra terminou, assim,

\footnotetext{
${ }^{22}$ ROBERT MORAES (2000:351) In: Bases da formação territorial do Brasil.

A importância estratégica do domínio do Maranhão e da foz do Amazonas foi bem avaliada pela geopolítica imperial filipina, o que se expressa nos esforços empreendidos pela fortificação e pelo povoamento da região. O gradativo controle da área também não passava despercebido das autoridades metropolitanas que, em 1621, criam o Estado do Maranhão com administração autônoma em relação à colônia brasileira.
} 
em caráter definitivo depois do cerco e da rendição do comando francês no dia 3 de novembro de 1615, quando ele aceitou 'Au camp, devant le fort de SaintLouis des Français", o ultimato do chefe português, Jerônimo de Albuquerque. (LYRA TAVARES,1979, p.99). De acordo com Celso Furtado, foi defendendo as terras da Espanha dos inimigos desta que os portugueses se fixaram na foz do grande rio, posição-chave para o fácil controle da imensa bacia (FURTADO apud ROBERT MORAES, 2000, p.350).

Os ibéricos capturaram Sr. La Ravardière, que era considerado um grande especialista na navegação maranhense e amazônicas e 0 mantiveram preso por acreditar que La Touche havia realizado uma aliança com os holandeses para reconquistar o território do Maranhão. Ora, os holandeses tinham disponíveis, naquele momento, uma força militar pronta para o ataque, muito superior à da França. Uma aliança frança-holandatupinambás, muito provavelmente, seria páreo para as forças hispanoportuguesas. "Segundo uma das versões, La Touche, já considerado um dos principais especialistas em navegação 'maranhense', queria retornar ao Maranhão com o apoio militar e logístico dos batavos" (CARDOSO, 2011).

Assim as autoridades portuguesas em Lisboa retardam a soltura de La Touche (Sr. La Ravardière) e conseguem, neste momento, neutralizar as forças "invasoras" francesas e ter como preocupação maior os holandeses, que irão ser responsáveis pelo mais duradouro projeto não português em seu território colonial americano e atacariam todo seu Império marítimo como costa Africana, Oriente Médio, Ásia Meridiona, Sudeste Asiático e etc.

À medida que avançamos os primeiros anos do século XVII, cada vez mais as preocupações hispano-lusas se concentram nos holandeses. E, no final das contas, existiam muitos motivos para tanto, já que à diferença dos ingleses os 'rebeldes de Holanda' tinham melhor organização, além de maior estrutura bélico-naval, e projetos mais específicos a respeito do Atlântico Sul. Entretanto, parece claro que o objetivo central de ingleses e irlandeses na região estava mais inclinado para a organização de pequenos entrepostos comerciais, com pretensões relativamente limitadas. $\mathrm{O}$ caso holandês era, em muitos sentidos, diferente. (CARDOSO, 2011:323). 
Os holandeses, na Bacia Amazônica, fixaram-se no vale do Xingu. Acontece que a ação holandesa, como vamos ver adiante, teve um contexto muito mais amplo. A guerra entre espanhóis e holandeses está relacionada com a luta pela sucessão dinástica dos Habsburgos nos Países Baixos; a Contra-Reforma na península lbérica e a fuga dos protestantes e judeus para os Países Baixos; a independência da República das Províncias Unidas Holandesas e a expansão comercial marítima na rota do Atlântico e Ásia e a criação da Companhia das Índias Ocidentais. Portanto, do ponto de vista dos Espanhóis o projeto holandês é algo que choca diretamente com as pretensões hegemônicas habsburguesas.

Apesar da trégua, estabelecida desde 1609, entre a nova 'República' e o Reino da Espanha, durante toda a primeira metade do século XVII os chamados Confederados de Utrecht criaram uma política bastante agressiva em relação aos domínios ultramarinos hispano-lusos. Para o Atlântico, as investidas se tornaram cada vez mais claras e organizadas, principalmente após a fundação, já em 1621, da West-Indische Compagnie (WIC). Para piorar o quadro geral, a partir de 1605, as Repúblicas Holandesas ganhavam o controle de parte considerável das rotas comerciais asiáticas. (CARDOSO, 2011:324)

Os batavos tiveram uma ação incipiente na bacia Amazônica. No Caribe, é provável que tenham costeado a foz do rio Orenoco; na foz do Rio Amazonas adentrado até o Xingu no fim do século XVI. Segundo CARDOSO (2010), Filipe IV, em 1631, é alertado por um irlandês de nome Gaspar Chilan sobre as ocupações holandesas e recomenda que o rei trouxesse soldados irlandeses católicos para juntos lutarem contra a ocupação dos hereges. Entretanto, apenas em 1641 os holandeses tentam invadir o Maranhão com as forças "sob o comando do almirante Jan Corneiliszoon Lichthardt, e ficará praticamente restrita à ilha de São Luís, pouco atingindo a capitania do GrãoPará" (Ibidem, 2011:325).

Em 24 de novembro de 1641 - Apresentando-se sem arvorar bandeira, a esquadra holandesa de Lichthardt, com 19 navios, troca alguns tiros com os fortes, mas termina por receber boa acolhida por parte do governador Bento Maciel Parente. Ocupando a cidade e o forte os holandeses deram por rompida a convenção pactuada com Bento, prenderamno e o remeteram para Goiana, onde viria a morrer. A guarnição de São Luís, 130 homens, foi enviada para um 
presídio holandês nas Antilhas. Permaneceram como senhores do Maranhão até 28 de fevereiro de1644, quando os expulsou sublevação popular liderada por Antônio Muniz Barreto e Antônio Teixeira de Melo. (DONATO,1996: 519)

Até onde realmente alcançava o poder dos Habsburgos na América portuguesa ${ }^{23}$ ? Se na Europa os portugueses estavam voltados para crise política, na América eles não perdem seu tempo. Em 1616, fundam o forte Presépio no lugar onde fica a atual cidade de Belém.

A localização estratégica do Forte, na foz do Amazonas, permitia aos portugueses fecharem a passagem sul do rio para o Oceano Atlântico, além de fechar a entrada para o interior do continente pois, o forte estava localizado na foz do rio Tocantins "a 'Capitania do Grão-Pará', cuja sede será a cidade de Belém, fundada pelos portugueses em 1616, num desdobramento das ações militares de tomada do Maranhão" (CARDOSO, 2011:325).

Belém estava melhor posicionada (do que São Luís) para vigiar a boca do grande rio, ameaçado sempre por incursões de navegantes franceses, holandeses e ingleses, assim como para servir de base logística às expedições exploratórias da imensa bacia respondendo as preocupações de Portugal. (MEIRA MATOS, 1980:35).

Em 1618, a Espanha se envolve em uma questão de complicações internacionais, a "Guerra dos Trinta Anos". Quando o conflito já dava sinais de uma derrota castelhana, os portugueses em terras coloniais aproveitam para expandir o seu domínio. No ano de 1637, Filipe IV da Espanha, temendo que o Estado do Amapá caísse em mãos francesas, cria a capitania de Cabo Norte, entregando aos cuidados de um donatário português chamado Bento Maciel Parente; o litígio desta região que esteve concentrada entre Portugal e França. Mais tarde a questão foi herdada ao Brasil Independente, mesmo com a demarcação do Amapá acordada pelo Tratado de Utrecht $^{24}$ em 1713-15, que delimitava as possessões lusitanas nas terras ao sul

\footnotetext{
${ }^{23}$ ROBERT MORAES (2000:351). In: Bases da formação territorial do Brasil.

Foi visto que a fórmula encontrada para incorporação mantinha uma autonomia formal da administração do reino português e de suas colônias, que passavam a ser dirigidas por um conselho - composto por elementos do clero e da aristocracia lusitanos - o qual respondia diretamente à Coroa espanhola, nos mesmos moldes do Conselho das Índias (ROBERT MORAES, 2000, p.345).

${ }^{24}$ KENNEDY (1988:109), P. In: Ascensão e Queda das Grandes Potências.
} 
do rio Oiapoque. Os franceses "ora reivindicam a fronteira no Araguari, ora no Carapaporis, ora no Cassiporé e Calsone. Esquecem-se de que o limite do Oiapoque não era questão diplomática discutível" (MEIRA MATTOS, 1980, p.43).

Então, como se observa a seguir na imagem da foz amazônica; o domínio da foz estabeleceu-se em mãos portuguesas que, mesmo sobre o regime político da União Ibérica, não se identificavam como compatriotas e sim aliados diante de uma situação geopolítica específica. É por isso que vamos tratar a conquista da Amazônia como parte de um destino distinto da União Ibérica, isto porque os portugueses que navegavam pela Bacia Amazônica, como se verá, não construíam fortes ou vilas para o Rei de Espanha e sim para o Rei de Portugal que, circunstancialmente, eram a mesma pessoa.

Portanto, a expansão do território português ocorreu devido aos esforços dos portugueses que viviam na América, identificados por lusobrasileiros. O Tratado de Madri (1750) irá considerar a ação luso-brasileira na Bacia Amazônica para delimitar os territórios coloniais da América do Sul de Portugal e Espanha, invocando o termo do direito romano "Uti possidetis", que reivindica a posse do território pelo uso, termo semelhante ao do uso-capião.

\section{O "Destino Manifesto" luso-brasileiro, a expansão territorial como forma de defesa: a expedição de Capitão Pedro Teixeira e os relatos de Pe. Cristóbal de Acuña.}

O domínio dos lusitanos em foz amazônica - posteriormente à fundação da Capitania do Cabo Norte (atual Estado do Amapá) - é total, tanto ao norte como, ao sul da foz do mar doce. Forma-se uma situação geoestratégica ideal para dar sequência ao projeto de expansão territorial portuguesa em áreas equatoriais.

As condições da paz que pôs fim à Guerra da Sucessão Espanhola foram fixadas nos tratados de Utrecht (1713) e Rastadt (1714) (...) Os reinos francês e espanhol permaneceriam separados para sempre, ao passo que a sucessão protestante na Grã-Bretanha era formalmente reconhecida. 


\section{Foz do Rio Amazonas}

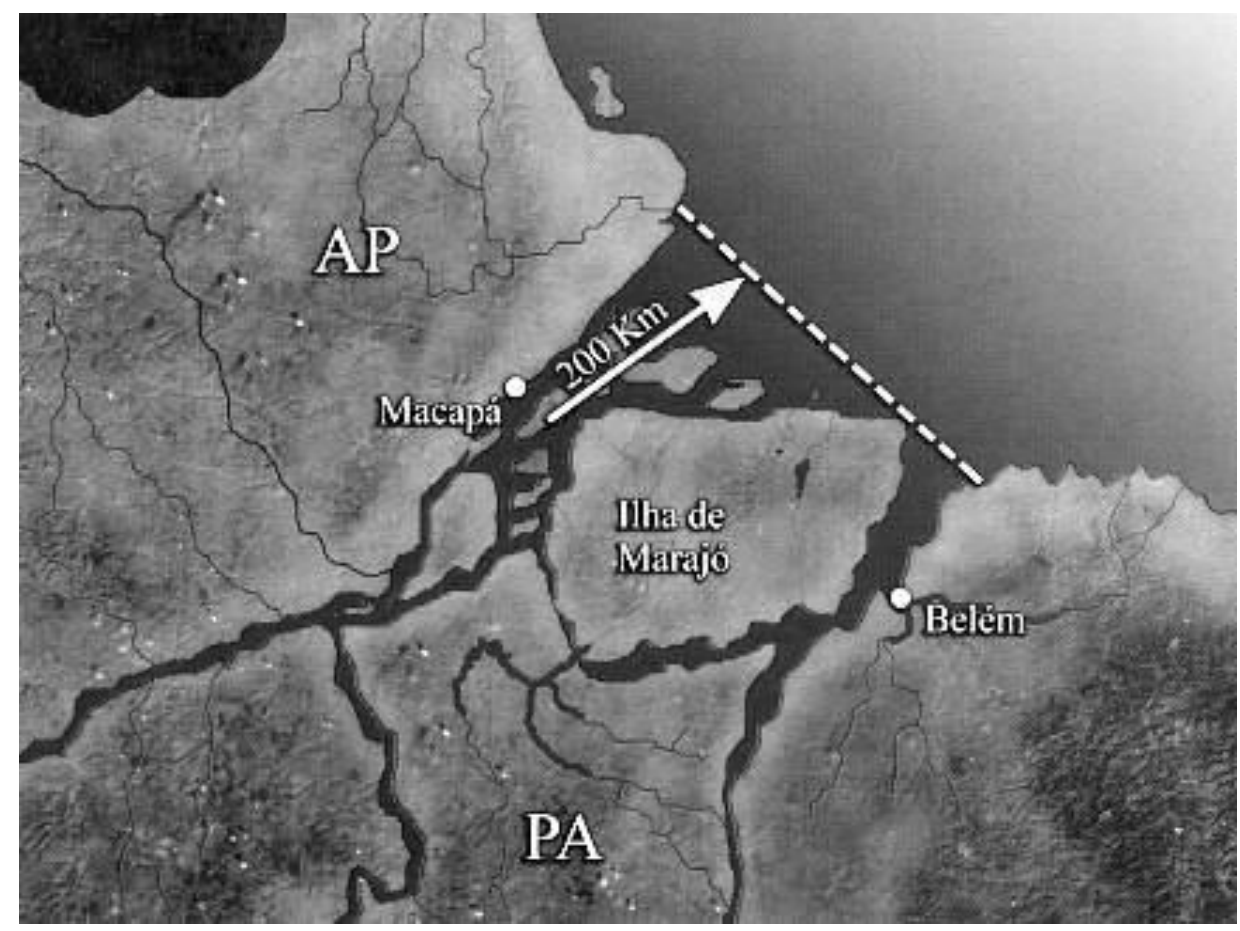

Figura 7 - Retirado de http://movimentoprobase.blogspot.com.br - acesso em 25 de junho de 2012.

No dia 28 de outubro de 1637, o capitão Pedro Teixeira partiu de Gurupará com uma grande expedição contendo mais de duas mil e quinhentas pessoas, somando-se mulheres, crianças e índios e mais de quinhentas embarcações.

O percurso seria o caminho inverso feito por Orellana. "O capitão Teixeira subiu o Amazonas, o Marañon, o Napo, abandonou as embarcações, galgou as escarpas da cordilheira e chegou ao grande altiplano andino em Quito no ano de 1639". (MEIRA MATTOS, 1980:34). O capitão fundou alguns fortes nos pontos estratégicos da imensa bacia do Amazonas. "O aparecimento de Pedro Teixeira surpreendeu e desagradou as autoridades espanholas". (Ibidem, 1980:34).

Segundo ESTEVES (1994), o susto das autoridades espanholas foi grande. Sem saber qual postura tomar diante desta situação, esperaram instruções do vice-rei do Peru que dissera que "Teixeira deveria ser enviado de volta pelo mesmo caminho por onde tinha vindo, recebendo todas as provisões 
necessárias para viagem"25 (ESTEVES, 1994: 18). As recomendações da coroa espanhola já indicam uma derrota da Espanha na Guerra de Restauração e, consequentemente, o fim da União Ibérica. Duas preocupações estavam em pauta: não deixar os portugueses expandirem tanto seu território na América do Sul e não deixar cair em mãos rivais (França, Holanda, Inglaterra) territórios coloniais nas Américas, principalmente na América do Sul.

A questão que retorna é até que ponto os luso-brasileiros aceitavam ou entendiam a União Ibérica: "a união peninsular propiciou ampliação do território colonial brasileiro, com a expansão nucleada pelas regiões de colonização já consolidadas que ultrapassa muito as fronteiras definidas em Tordesilhas". (ROBERT MORAES, 2000:352).

A expedição do Capitão-Mor português é um símbolo de que a União tinha uma conotação política, o que coloca o Capitão Pedro Teixeira, entre todos os "senhores da guerra" de nacionalidade lusitana, o que tinha uma visão mais aguda da situação geopolítica nas terras coloniais sul-americanas.

Os fortes, vilas e vilarejos fundados pelo capitão português foram utilizados como demarcações a favor de Portugal, com o fim da União Ibérica. Assim ocorreu, no século XVIII, dentro do contexto do equilíbrio de poder das dinastias europeias, o reconhecimento da expansão territorial portuguesa na região.

\begin{abstract}
A expedição de Pedro Teixeira havia sido de fundamental importância para os portugueses, interessados em estender seu domínio por todo vale amazônico. Teixeira plantou uma fortificação na região do alto Amazonas, a pequena distância de Quito, e ali colocou um marco português. Com a vigência da União Ibérica, tal ato passou despercebido, mas, com a restauração portuguesa pela casa de Bragança, (...) todo o território a leste daquele ponto passou a ser considerado como possessão de Portugal e, mais tarde, reconhecido como tal, pelos tratados de Ultrecht (1713), Madri (1750) e Santo Ildefonso (1777). Atualmente são territórios brasileiros. (ESTEVES,1994: 24)
\end{abstract}

\footnotetext{
${ }^{25}$ MATTOS (1980:34), Gen. M. In: Uma Geopolítica Pan-amazônica.

O Conselho das Índias de Madri, na Ata da reunião de 28 de janeiro de 1640, registrou as preocupações vindas das autoridades do Vice-Reinado do Peru. Diz o aludido documento $-Y$ sobre lo que en esta usurpación se les há disumulado se les permitisse ahora continuar las navegaciones por este rio, no hay sino dar por suyo todo el Perú y esperar que le ocupen ellos, haciendose dueños de sus riquezas y contrataciones y saqueando cuando les pareciere, sus más opulentas ciudades...
} 
A importância de Teixeira para a consolidação do projeto colonial português e para as bases da formação territorial brasileira foi singular. Pedro Teixeira participou de diversas e importantes Batalhas Navais contra os invasores estrangeiros da Amazônia: a seguir estão algumas participações do capitão português na Bacia Amazônica.

Em 1616, ainda alferes, acompanhou a expedição de Caldeira Castelo Branco para fundar o Pará e construir o Forte Presépio. Seu primeiro grande feito militar foi atacar e se apoderar de uma nau holandesa que, antes de ser afundada, teve seus canhões pilhados e doados para o forte recémfundado. Ainda no mesmo ano, 1616, faz viagem por terra de Belém a São Luís.

Em 1625, ataca o Forte holandês no rio Xingu e expulsa os holandeses e, mais tarde, dirige-se à margem esquerda da Bacia Amazônica e também expulsa os ingleses. Em 1626, sobe o rio Amazonas e o Tapajós e faz um bom relacionamento com os índios. Em 1629, com Pedro Favela, toma o Forte Torrega, no Amazonas, onde estavam aquartelados 2.000 homens. Vence os ingleses, escoceses e irlandeses que o defendiam. Em 1631, com expedição comandada por Jácomo Raimundo de Noronha, ataca o novo forte em que estavam os ingleses na outra margem do Amazonas, destrói o forte e os ingleses são trazidos prisioneiros a Belém.

Em 1637, parte com destino a Quito, no então vice-reino do Peru, atual Equador, percorreu o Amazonas, do Atlântico até às suas nascentes pelo Rio Napo, voltou pelo mesmo caminho, fazendo a viagem de ida e volta: subida e descida (Outubro de 1637 a Dezembro de 1639). Em 1640, Pedro Teixeira foi nomeado Capitão-Mor e Governador da capitania do Pará ${ }^{26}$.

A grande expedição do Capitão-Mor Pedro Teixeira é analisada de forma realista pelo Padre da Companhia de Jesus, Cristóbal de Acuña, em seu relatório, que mais tarde tornou-se um clássico, intitulado "Novo Descobrimento do Rio Amazonas". Oferecido ao conde-duque de Olivares, o libelo é publicado pela primeira vez em Madri, no ano de 1641. A edição

${ }^{26}$ Informações colhidas do Portal dos Bandeirantes. In: http://www.bandeirantessp.com.br/estudos8.html (acesso em 24/07/2012). 
bilíngue, utilizada no presente trabalho faz parte da "Coleção Orellana", editada pela Embaixada da Espanha e traduzida por Antônio R. Esteves (1994).

O Capitão Teixeira havia levado seu escrivão para oficializar em nome da Coroa portuguesa suas descobertas. Na volta da viagem, Quito-Pará, o corregedor do Vice-Rei do Peru, ordenou que em seu retorno Acuña e seu companheiro Andrés de Artiega acompanhassem a expedição fazendo um relatório para sua Majestade, Filipe IV da Espanha.

A chegada do jesuíta Padre Acuña na expedição marca, além da desconfiança mútua entre portugueses e espanhóis, a disputa política entre a ordem jesuítica e a ordem dos franciscanos no Vice-Reino do Peru. "Os franciscanos foram os primeiros a se estabelecerem no Peru desde 1536. Os Jesuítas chegaram apenas em 1557" (ESTEVES, 1994:23). É por esse motivo que os franciscanos "atribuíram ao tráfico de influências dos jesuítas o fato das autoridades espanholas terem nomeado dois religiosos daquela congregação" (ibidem, 1994:23). Isto porque Acuña era irmão do corregedor do rei em Quito, o cavaleiro da Ordem de Calatrava, Dom Juan de Acuña. Os portugueses preferiam o padre franciscano Andrés Brievas para acompanhar Pedro e Bento Teixeira na viagem de volta, pois este já havia percorrido o rio nos dois sentidos.

O padre José Maldonado, na sua Relación de Descubrimiento del Rio de las Amazonas llamado Marañon hecho por médio de los religiosos de la Provincia de San Francisco de Quito, escrito para defender o interesse dos franciscanos, afirma que, atendendo o pedido dos portugueses, seus superiores autorizaram o frei Brieva a realizar a viagem. Ordenava, ainda, que de Belém passasse à Espanha e em nome de sua Ordem prestasse conta de tudo ao rei e ao Conselho das Índias. Apesar de ter sido proibido de embarcar pelas autoridades espanholas, o franciscano desobedeceu e embarcou, tendo acompanhado a expedição. (ESTEVES, 1994: 24).

A obra de Acuña (op.cit, 1641) é carregada de alguns problemas típicos da época em que foi escrita; possui uma visão "edenista" de que a terra descrita era um verdadeiro paraíso. Este tipo de relato sobre Amazônia era comum entre os séculos XVI a XIX. Em sua época, o autor fazia um apelo para incentivar a colonização daquele lugar onde tudo, aparentemente, parecia ser uma dádiva divina. No entanto, no século XX descobrimos que realmente a 
bacia Amazônica não é apenas rica em recursos, mas fundamental para todo o planeta. Portanto, sugere-se, para o presente trabalho, a análise de alguns trechos desta obra. Eles estão relacionados aos conceitos da geografia aplicada ao uso militar e a política.

Logo na abertura do livro, há um oferecimento ao conde-duque Olivares e ao Rei Filipe IV da Espanha. Como já fora comentado anteriormente, o Padre Acuña abre os olhos dos nobres espanhóis para o tamanho do reino que estava para ser descoberto e compara com a área colonial espanhola da América do Sul, acreditando que a região seria maior, mais rica e muito mais diversa do que qualquer outra área a ser colonizada no globo.

\begin{abstract}
E se a extensão que se divulga do Peru se reduz a cerca de mil e quinhentas léguas, medidas desde o Novo Reino de Granada até os últimos confins do Chile. Com muito mais razão pode se dar ao território do Rio Amazonas o título de Grande, pois no espaço de quase quatro mil léguas de contorno encerra mais de cento e cinquenta nações de línguas diferentes, suficiente, cada uma delas, para formar sozinha um vasto reino. (ACUÑA, 1994: 37).
\end{abstract}

A precisão dos dados de Acuña é claramente questionável, era difícil para ele ou qualquer outro de sua época ter dados precisos da superfície da terra, mas a proporção não é tão equivocada como podemos perceber com os dados atuais. A América do Sul possui, aproximadamente, 17 milhões de $\mathrm{km}^{2}$ e a Bacia Amazônica ocupa uma área de 7 milhões de $\mathrm{km}^{2}$ quase $45 \%$ do território sul-americano. A figura-4 mostra a dimensão da região que Acuña faz sua análise. $O$ jesuíta espanhol chama atenção para diversidade étnica: que rei em seu período teria mais de cento e cinquenta nações sobre o seu domínio? Padre Acuña compara está área com outros grandes impérios como Etiópia e a China. É verdade que a grandeza territorial e as dificuldades naturais de se fixar na Amazônia não são comentadas por ele.

se o vasto império da Etiópia se eleva com tão glorioso nome, por ocupar novecentas léguas. Se a grandiosa China, por encerrar em duas mil léguas de fronteiras e quinze diferentes reinos, espanta o mundo com sua grandeza (ACUÑA, 1994:37) 


\section{Imagem de Satélite da Bacia Amazônica}

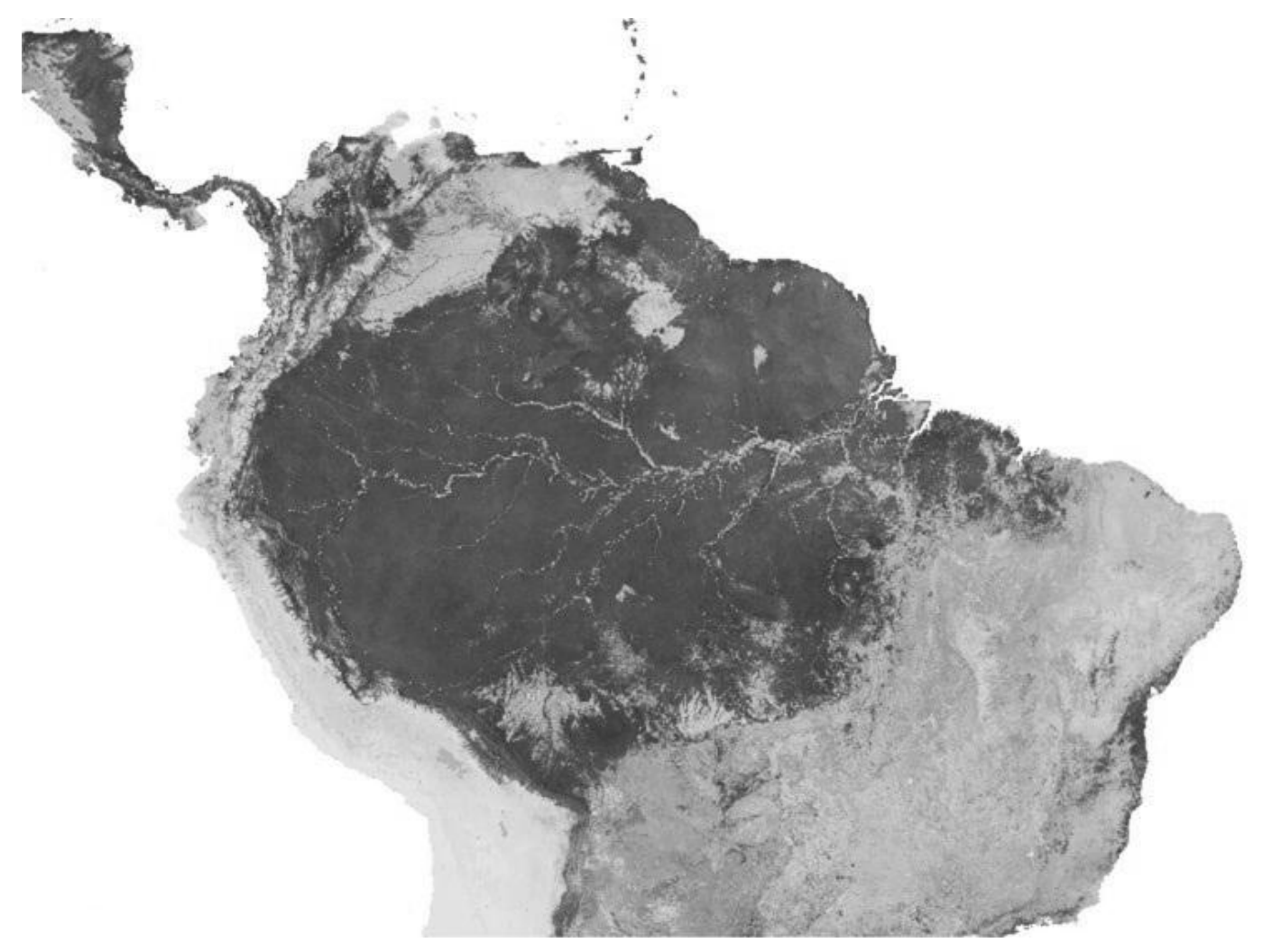

Figura 8 - Retirado de http ://www .geografiaparatodos.com.br/img/mapas_fisicos/ amazonia_america_do_sul.jpg-acesso em 25/07/2012.

O volume do relato tem o certificado do próprio Capitão-Mor Pedro Teixeira, que em alguns momentos é enaltecido pelo autor, embora se possa observar que tudo que foi relatado antes deveria passar pelo crivo do capitão português.

e para ser verdade tudo o que aqui contém, expedi este certificado, firmado de meu próprio punho e selado com o selo de minhas armas. Nesta cidade do Pará, a três de março do ano de mil seiscentos e quarenta (TEIXEIRA apud ACUÑA, 1994: 43).

Nos primeiros oito capítulos, o padre jesuíta ressalta as viagens anteriores feitas por Francisco Orellana, Lopes de Aguirre, Francisco Coelho e os dois religiosos leigos Domingo de Brieva e frei Andrés de Toledo. Nessa introdução, onde ocorre a explicação dos primeiros descobridores do Amazonas; Cristobal de Acuña constrói uma tese sutil diferenciando os navegadores castelhanos dos portugueses e quando ele se refere ao português Bento Maciel Parente, quando governador-geral do Maranhão, 
aponta o sentimento que movia as expedições portuguesas pelo Grande Rio. Esse momento histórico nos revela o porquê da transferência da capital do Grão Pará e Maranhão de São Luís para Belém um século mais tarde.

Esses desejos de descobrimento não moviam apenas os ânimos dos castelhanos, pela parte do Peru, mas estendiam-se também pelas costas do Brasil, ocupadas pelos portugueses, que quiseram, com zelo que sempre têm de aumentar as possessões de sua coroa, começando desde a foz deste rio, alcançar suas nascentes e desentranhar suas riquezas. (ACUÑA, 1994:55).

É por isso que se torna tão importante em seu relato a minúcia das datas e a descrição da expedição realizando uma Geografia Militar no Brasil, é certo que esta ainda bem rudimentar. Os detalhes do tamanho da tropa: o número de embarcações, número de soldados e experts, o tempo da viagem, a estratégia usada para a navegação, para a marcha e o uso de táticas indígenas de guerra são relatadas pelo jesuíta espanhol. Segundo Acuña, na sua viagem, do Pará a Quito, subindo o rio, a bandeira de Pedro Teixeira percorreu uma distância de aproximadamente $8.100 \mathrm{Km}$. Sem as entradas de verificação, pela foz dos grandes rios e pelas aldeias de índios, a distância corresponde a, aproximadamente, $6.700 \mathrm{Km}$. Assim sendo, a viagem de ida e volta da Bandeira de Pedro Teixeira contando entradas em rios e trilhas foi de aproximadamente, $13.400 \mathrm{Km}$, movimentando um contingente de mais de 2.000 pessoas. Contando Belém-Quito, percurso simples de ida e volta, pelas medidas atuais, a distância total, ida e volta é de aproximadamente $11.500 \mathrm{Km}$.

A expedição partiu "dos confins do Pará, no dia vinte e oito de outubro de mil seiscentos e trinta e sete" (ACUÑA,1994: 63), tamanho da tropa e veículos: "com quarenta e sete canoas de razoável porte e nelas setenta soldados portugueses, mil e duzentos índios remadores e guerreiros, que com as mulheres e rapazes ultrapassariam duas mil pessoas" (Ibidem, 1994: 63). O Padre chama a atenção para o abastecimento da grande tropa, que sempre fora um dos grandes problemas da expedição, pois sua tropa era numerosa: "Durou a viagem cerca de um ano, tanto pela força das correntezas, como pelo tempo dispendido em conseguir mantimentos para alimentar tantas bocas" (Ibidem, 1994:63). 
A estratégia da navegação e marcha da tropa, relatadas por Acuña, mostram a destreza e o conhecimento de Teixeira para conduzir a expedição, isso rende uma série de elogios do padre espanhol ao Capitão-Mor; usando a tática romana de marcha longa, delega o Coronel Bento Rodrigues Oliveira o papel de exploratore ${ }^{27}$. A longa viagem fez com que muitos dos índios soldados da expedição desertassem, assim regressando para suas terras. Para não perder mais homens, Teixeira mandou um grupo de exploratores a frente, enquanto convencia os demais que o fim da viagem estava se aproximando, mesmo ainda na metade do percurso, desta forma manteve a tropa esperançosa diminuindo o número de deserção.

Maquiavel, em a "Arte da Guerra", fala-nos sobre o que ele designa de inganno, que é a dissimulação que deve ser aplicada tanto externamente, ou seja, contra o inimigo, como internamente, muitas vezes os soldados não devem conhecer quais as intenções do comandante e a verdadeira situação do front de combate.

Desse modo, mesmo que se achassem ainda na metade do caminho, Pedro Teixeira fingiu que já estavam muito próximo do final. Preparou então oito canoas bem guarnecidas de remadores e soldados, e mandou-as ir na frente buscar acomodações para o restante da tropa. $\mathrm{Na}$ verdade, não eram nada mais que exploradores do melhor caminho, que separavam o certo do duvidoso. (ACUÑA, 1994: 63)

O destaque dado à retórica dos comandados também pode ser percebido neste relato, ao designar o Coronel Bento Rodrigues Oliveira para realizar a tarefa de explorador, o Capitão Pedro Teixeira estava elegendo não apenas um bom comandante, mas um filho do Brasil, alguém que falava a língua dos comandados, ele havia sido criado com os índios e sabia lidar com as situações mais críticas dentro do ambiente de floresta.

Maquiavel rasga elogios a Alexandre, o Grande, pois dizia o pensador italiano, que, mesmo depois de tudo que havia conquistado, conseguia manter o ânimo de seus exércitos, mesmo cansados e em

\footnotetext{
${ }^{27}$ KEEGAN (2006:27), J. IN: Inteligência na Guerra.

procursatores, que realizavam reconhecimento próximo, imediatamente à frente do exército; exploratores, batedores de longo alcance; e speculatores, que faziam espionagem nas profundezas do território do adversário
} 
ambientes hostis como o deserto da Árabia e lugares longínquos como a Índia ${ }^{28}$.

\begin{abstract}
Pedro Teixeira nomeou como chefe desta esquadrilha o coronel Bento Rodrigues de Olivares, filho do Brasil e pessoa que, tendo sido criada entre os nativos, podia adivinhar-Ihes o pensamento e saber o que passava por seus corações. Isso tornou-o conhecido, temido e respeitado por todos os índios das operações de conquista das quais participou e, no presente descobrimento, foi de fundamental importância para o bom resultado a que se chegou. (ACUÑA, 1994: 63)
\end{abstract}

No decorrer do seu relato, o padre jesuíta faz uma menção ao que seria a melhor localização e recomenda aos nobres espanhóis que construíssem uma fortificação capaz de impedir a subida de quem vem da jusante da Bacia Amazônica. O espanhol classifica o lugar como um estreito profundo e apresenta a sua condição natural como sendo a ideal para construção de uma fortificação, como se pode perceber pelo seu comentário.

O maior estreito onde este rio recolhe suas águas tem pouco mais de um quarto de légua, na altura de dois graus e dois terços. Tal lugar, sem dúvida, a Divina Providência previu, estreitando esse imenso mar doce, para que nesse estreito canal pudesse se fundar uma fortaleza que impeça a passagem de qualquer armada inimiga, por muitas forças que traga, se por acaso penetrar pelo curso principal do rio. E claro que, se penetrar pelo rio Negro, é nele que se deve colocar a defesa. Localiza-se tal estreito, a trezentas e sessenta léguas da barra, de onde em oito dias, com embarcações rápidas, a vela e a remo, se pode mandar aviso, muito antes que o inimigo se aproxime. (ACUÑA, 1994:81).

O relato de Acuña está inserido na disputa entre franciscanos e jesuítas, como já fora afirmado, pelo direito de estabelecer suas missões na Amazônia. Pedro Teixeira, na viagem de volta, fez um ato simbólico de posse semelhante ao de Raposo Tavares, ao fundar, no Rio Napo, abaixo da foz do rio Aguarico, uma povoação com o nome de Franciscana, fincando aí um marco divisório, servindo de baliza aos domínios das Coroas de Castela e de

\footnotetext{
${ }^{28}$ MAQUIAVEL( 2006:136), N. Arte da Guerra.

Lede a vida de Alexandre Magno e vereis quantas vezes foi preciso discursar e falar publicamente ao exército; não fosse isso, depois que seu exército se tornou rico com o fruto das pilhagens, ele jamais o teria conduzido para os desertos da Arábia e para Índia com tanto desconforto e incômodo.
} 
Portugal, um ano depois, com a Restauração da casa de Bragança, praticamente toda a bacia amazônica ficaria em mãos da Coroa de Portugal. No cerimonial da fundação e demarcação de limites e fronteiras, declara o escrivão, formalmente:

Eu, escrivão, tomei estas terras nas mãos e as dei nas mãos do Capitão-Mor (Pedro Teixeira)(...) investido da dita posse, pela Coroa de Portugal, no dito sítio e mais terras, rios, navegação e comércio (...) Se houver entre os presentes, alguém que contradiga ou embargue este ato, que 0 escrivão da expedição o registre. ${ }^{29}$

Esta expedição tem justamente o papel de possibilitar que o Brasil tivesse território suficiente para ser ocupado, mas, principalmente, para criar uma retaguarda ao povoamento Atlântico português. Da mesma forma que ir para o interior era uma defesa para o índio, ir para o interior para os lusobrasileiros era uma forma de defesa contra os núcleos andinos, isso pelo fato de ter uma grande distância a ser percorrida para se chegar ao núcleo de povoamento atlântico português e criar uma retaguarda, terreno de fuga, para ataques vindos do mar, que foi o caso da guerra contra os holandeses.

$\mathrm{Na}$ Guerra, geralmente as pessoas da terra possuem vantagens sobre o assaltante por conhecerem melhor o território que o inimigo. $\mathrm{Na}$ Floresta Amazônica, os habitantes da terra são as nações indígenas e esses estão bem adaptados às condições naturais da região das florestas úmidas. Não é tarefa fácil viver nessas áreas, é preciso ter um conhecimento que, neste caso, foi passado de geração em geração. Os portugueses, no caso da tropa do Capitão Pedro Teixeira, estavam bem adaptados aquelas condições e, mesmo assim, alguns deles desistiram antes mesmo de chegar na andina cidade de Quito. Em sua maioria, eram índios e mestiços e tinham o hábito de se locomover por matas e eram em combate muito aguerridos. O relato do espanhol destaca essa virtude portuguesa frente à dos outros invasores, a virtude de ter absorvido o modo de vida indígena para se locomover pelos sertões e ganharem terreno.

O que mais admira é o pouco trabalho que custa conseguir todas essas coisas, como se pode comprovar com o que

\footnotetext{
${ }^{29}$ Portal do Bandeirante. http://www.bandeirantes-sp.com.br/estudos9.html (acesso 14 de janeiro de 2013).
} 
cada dia experimentávamos em nosso acampamento, de onde depois de parar para pernoitar e depois que os índios amigos que nos acompanhavam faziam as barracas suficientes para o alojamento de toda a expedição, o que consumia um grande tempo, esses índios repartiam, alguns por terra, com cães, em busca de caça, e outros por carregados de peixe e com caça suficiente para alimentar todos. Isso não ocorreu uma vez ou outra vez, mas enquanto durou a viagem, que foi longa, como já disse. (ACUÑA, 1995: 93)

O relato segue exaltando as riquezas naturais da Amazônia como forma de convencer o Duque de Olivares a estruturar uma empreitada que desse conta de dominar a Bacia Amazônica e assim explorar aquela riqueza (madeira, óleo, frutas, peixes, couro, ouro, drogas medicinais e etc). Tudo isso por si só já seria interessante para que se projetasse uma empresa colonial e entrasse na briga contra os restauradores portugueses. O Padre Jesuíta chama atenção para os meios de locomoção ideal para região e exaltou as pequenas e rápidas embarcações do grupo de Teixeira e das nações indígenas locais.

O transporte na região amazônica deve aproveitar todo 0 potencial natural da rica e densa rede de drenagem amazônica e seus rios que possuem, geralmente, em boa parte do ano, grande caudalosidade. 0 transporte fluvial se impõe naturalmente e as comunidades culturalmente produziram um modo de vida que inclui o fabrico de embarcações. Ademais, o padre espanhol chama atenção para qualidade das madeiras da Amazônia o uso como matéria prima para barcos. "São cedros, sumaúma, pau-ferro, pauvermelho e muitas outras, já conhecidas como as melhores do mundo para fabricar embarcações nesse rio" (ACUÑA, 1995: 97).

Todos os que vivem às margens deste grande rio estão reunidos em grandes povoações e, como venezianos ou mexicanos, todas as suas relações são feitas por água, embarcações pequenas que se chamam canoas. Tais canoas são, normalmente, feitas de cedro, madeira com a qual a divina Providência lhes proveu abundantemente, sem que lhes custe aos nativos nem o trabalho de cortá-la ou tirá-la dos montes, enviando-a pelas avenidas do rio que, para suprir esta necessidade, arranca-a das mais distantes cordilheiras do Peru e a coloca, através das correnteza das águas, às portas de suas casas, onde cada um escolhe a que melhor lhe parece. (ACUÑA, 1995: 109) 
Acuña, percebendo que aquelas áreas dificilmente ficariam com a Coroa espanhola, realiza um inventário sobre a jurisdição territorial da mesma em terras meridionais. Do ponto de vista geoestratégico, toda a vantagem estava do lado dos luso-brasileiros. Entrementes, o padre jesuíta aponta oito entradas possíveis de realizar pelo Reino de Nova Granada: "três delas em direção dos lados do Novo Reino de Granada, que se localiza na parte norte deste Rio; na parte sul, veremos outras quatro, e uma debaixo da linha equinocial". (ACUÑA, 1995: 121).

Segue o relato das três entradas que há pelo novo reino: neste ponto Acuña delimita os povoamentos de domínio espanhol na fronteira do domínio português, ou seja, até onde chegava o território dominado pela Espanha na Bacia Amazônica. Segundo o padre o Reino de Nova Granada tinha pelo menos três entradas: uma delas era o rio Caquetá na província de Micoa em Santa Fé de Bogotá, Timaná e Caguan; a segunda entrada no povoado de Pasto na jurisdição de Popayán chegando de barco pelo rio Putamayo; e a terceira, que se pode tentar pelo norte, no princípio da província dos Encabelados, que está a noventa léguas do rio Napo. Essa entrada é realizada pelo rio Aguarico e pelo Rio Orinico.

A entrada pela parte sul encontra-se a cidade de Cofanes, porta de entrada para Quito, navegando pelo rio Coca se toma o canal principal do Rio Amazonas, as muitas corredeiras não fazem dele a melhor opção para se alcançar o rio Napo. "Destas, a primeira de todas, ainda que não a melhor, é pela cidade de Ávila, no mesmo governo dos Quijos, de onde a três jornadas por terra se vem a dar no rio Payamino, onde a armada portuguesa aportou, na jurisdição de Quito" (ACUÑA, 1995: 125). A quinta passagem para acessar o Rio Napo é pela cidade de Archidona, também fazia parte do governo de Quijos, jurisdição de Quito. "Por esse novo caminho em um só dia de viagem, a pé por ser inverno, pois em tempos de verão se pode andar a cavalos, demos no porto do rio Napo" (Ibidem, 1995). Pela província de Macas, a sétima entrada para Bacia Amazônica, "desce o rio Curaray, seguindo-se seu curso pode-se também sair ao Rio Amazonas, na altura de dois graus, a cento e ciquenta léguas do Napo" (Ibidem,1995). E a oitava entrada é apontada o povoado de Santiago das Montanhas na província de Maynas. 
A possibilidade de os portugueses terem o Grão Pará como território de retaguarda e, ao mesmo tempo, a distância que os núcleos espanhóis ficaram dos principais núcleos povoadores de Portugal foram o resultado mais importante que Capitão Pedro Teixeira conseguira. Essa estabilidade dada pelo alargamento do Território português foi fundamental para que os portugueses pudessem fugir e se reunir e depois organizar uma retomada das áreas ou mesmo poder alimentar insurreições ou guerrilhas. Isso, indiretamente, favoreceu os portugueses na luta contra os holandeses no Nordeste. Tanto isto é verdadeiro, que, quando os holandeses conquistam, em 1640, São Luís no Maranhão, não conseguem deter os portugueses que, tendo como praça de apoio o Forte Presépio de Belém, não tiveram tantas dificuldades para expulsar os batavos um pouco menos de um ano depois. Mas a guerra contra os holandeses veio a ensinar uma coisa muito cara para todos os filhos do Brasil: "o mar domina o Brasil". Para ter uma vitória definitiva contra os inimigos, Portugal teria que retomar o seu posto no Atlântico Sul; entretanto, isso nunca mais seria possível na escala que fora nos século XV e XVI. 


\section{CAPÍTULO 3 - A GUERRA CONTRA OS HOLANDESES E BASES DA FORMAÇÃO NACIONAL: GUERRA DE GUERRILHA, DEFESA ESTRATÉGICA, RESISTÊNCIA.}

\section{Introdução}

O episódio da invasão holandesa no Brasil, datado de 1624-1654, gerou uma produção de documentos e relatos muito volumosa, assim como, a sua produção historiográfica. É, por este motivo, que o debate sobre causas, razões, intenções, traições, vinganças, intrigas, enganos e desenganos é tão grande quanto a sua produção bibliográfica. Será realizada nesta introdução, a explanação sintética do episódio histórico com a intenção de trazer para a pesquisa os caminhos feitos a partir da análise histórica que foi construída da leitura de diversos historiadores contemporâneos. Os autores, muitas vezes, dão uma interpretação dos fatos que divergem entre si, não poderia ser diferente, assim os confrontando, estabelecem-se novas interpretações e impressões.

Existe uma série de publicações realizadas por historiadores brasileiros. Hoje em dia, o mais atualizado e conhecido compêndio de documentos deste episódio histórico é encontrado na publicação "O Brasil holandês" (2010), de Evaldo Cabral de Mello. O historiador organizou recortes de relatos e documentos para uma narrativa de três momentos deste período: A invasão, que para o levantamento da Geografia Militar no Brasil é capital; o governo de Nassau, que para presente pesquisa não é tão importante como os episódios iniciais e finais do confronto; e, por fim, a insurreição, a luta para expulsar os holandeses do Nordeste brasileiro. Assim, a Geografia Militar do período, "estando necessariamente vertebradas tanto na primeira (A guerra de resistência) como na terceira (A guerra de restauração) pelos episódios de natureza política e militar" (MELLO, 2010:21). Segundo MELLO (2010), as estratégias, táticas, relato dos grandes sucessos bélicos, batalhas navais, autoridades metropolitanas entre outras informações terão nestes episódios um caminho repleto de detalhes. 
Segundo MELLO (2010), os historiadores José Higino e J. A. Gonçalves de Mello foram, em boa parte, responsáveis por organizar, traduzir e compilar uma boa parte de documentos e relatos de origem holandesa.

Não usaremos apenas os documentos do período, embora estejamos de acordo com MELLO (2010), que "velhos textos venham a convencer mais do que toda uma monografia histórica"; no entanto, as monografias nos colocam questionamentos que os textos do momento não teriam condições de fazer por não terem na mão os desdobramentos do episódio. Então, foram de grande valia os estudos de Capistrano de Abreu "Capítulos da História Colonial", publicado pela primeira vez em 1907. A maturidade do texto e o nível de informação estão muito além de seu tempo e irão influenciar uma série de pensadores brasileiros, tais como Sergio Buarque de Holanda (1989): "A época colonial", em "História Geral da Civilização Brasileira", $8^{\mathrm{a}}$ edição - uma historiografia crítica e politizada do período dos Três Filipes no Brasil. Há ainda Antônio Paim (2000), como "Momentos Decisivos da História do Brasil", estudo que ressaltou as características da elite comercial e financeira de Portugal e questiona de que forma esta influenciou as cortes filipinas. Outro autor influenciado pelo texto de Capistrano de Abreu é Hernani Donato (1996), em seu "Dicionário das Batalhas Brasileiras", fonte de consultas inestimáveis para a obtenção de dados como localização, tipo de força, números, comandantes, entre outros. $E$ há também o historiador inglês Charles Boxer (1961), em "Os holandeses no Brasil, 1624-1654", crítico da historiografia luso-brasileira, ressalta aspectos que se aplicaram no Brasil, mas não no resto das ex-colônias do império ultramarino português.

Os relatos e documentos usados para o levantamento da Geografia Militar no Brasil são: "O Valeroso Lucidênio" (1648), de Frei Manuel Calado, obra clássica e carregada do espírito da época é quase um arauto da luta da fé católica e, mesmo assim, a leitura proporciona acessar a visão de uma testemunha ocular; "Memórias Diárias da Guerra do Brasil" (1654), de Duarte de Albuquerque Coelho e "Nova Lusitânia, História da Guerra Brasílica" (1675), de Francisco de Brito Freire, que, embora alguns trechos estejam no compêndio de MELLO (2010), os dois últimos possuem edições atualizadas e revisadas na íntegra; impressas pela Editora Beca (2003). Junto a essas duas 
obras, a editora disponibilizou um CD-ROM com outros relatos e documentos digitalizados e traduzidos. São eles: "Diário de Um soldado" de Ambrósio Richshoffer - publicado pela primeira vez em alemão em Strasburgo, em 1677, com o título de "Descrição de viagem ao Brasil e às Índias Ocidentais", traduzido e publicado em 1896, por Alfredo de Carvalho; "Olinda Conquistada", de Joan Baers, publicado em 1630 em Amsterdam; "Memorável Viagem Marítima e terrestre ao Brasil", de Joan Niehof, publicado em Amsterdam em 1682; "História dos feitos recentemente praticados durante oito anos no Brasil", de Gaspar Barleus, publicada em Amsterdam em 1647; "História ou Anais dos Feitos da Companhia Privilegiada das Índias Ocidentais, desde o começo até o fim do ano de 1636", de Joan de Laet, publicada em Leyden em 1644; "História das últimas batalhas entre os portugueses e holandeses" de Pierre Moreau, publicado em Paris em 1651; "Epanáfora Triunfante; Apontamentos da instrução para capitulação; Assento e condições da capitulação; Relação da vitória da segunda batalha dos Guararapes; Relação dos sucessos da Armada do Conde de Castelo-Melhor" de Francisco Manuel Melo, publicado em Madrid, em 1654.

A busca pelo alvorecer da Geografia Militar no Brasil se realiza plenamente neste episódio. É por isso que a Geografia Militar não é apenas brasileira, mas ela é estudada e analisada a partir do olhar daqueles que estão envolvidos no conflito em solos brasileiros. Nesse caso compreende-se a intenção por trás da primeira parte do título da tese em questão: "Geografia Militar no Brasil", e não somente a brasileira. Temos que o ponto de partida mais viável para um levantamento histórico deste tema deva começar no período dos três "Filipes" ${ }^{30}$ ou da União Ibérica e mais precisamente o episódio da guerra contra os holandeses. Os relatos das batalhas possuem origens mais diversas: português, luso-brasileiro, franceses, holandeses, alemães, espanhóis dentre outros. Portanto, estão aí as raízes da Geografia Militar do Brasil.

\footnotetext{
30 Os três Reis da Dinastia Filipina pertenciam à Casa de Habsburgo e governaram em Portugal entre 1580 e $1^{\circ}$ de Dezembro de 1640. Foram: Filipe I de Portugal e II de Espanha (1580-1598);Filipe II de Portugal e III de Espanha (1598-1621); Filipe III de Portugal e IV de Espanha (1621-1640).
} 
Alguns aspectos são importantes para entender minimamente a dimensão deste conflito. Nesta introdução, serão apresentados pelo menos cinco aspectos mais relevantes para o estudo: o primeiro aspecto é o dinástico, representado pela tentativa hegemônica dos Habsburgos na Europa e no mundo, com a liderança da Espanha (o Estado mais consolidado do domínio habsburguês), atrair para si um status de poder mundial impondo os seus ideais religiosos a todos os recantos do globo; a questão política, outra dimensão do conflito, é simbolizada pela União Ibérica, o conflito se desenrola na política desta união; o aspecto geopolítico tem como expressão principal a guerra entre Espanha e Holanda no século XVI-XVII; o aspecto financeiro, apresentado a historiografia brasileira por PAIM (2000) é bem relevante, pois o sistema bancário internacional começava a se estruturar e seus principais devedores eram os Estados e seus príncipes; e o quinto aspecto, o geoestratégico, que envolvia o domínio da rota comercial do Atlântico Sul, uma questão tordesilhana que perdia o sentido a partir do momento que Portugal ficou submetido a política castelhana.

A política de adquirir um status de poder maior foi elaborada por Ferdinando e Isabel de Castela, que armaram o casamento de sua filha Joana, a Louca, com Filipe da Áustria, filho do Sacro Imperador Maximiliano I, da família Habsuburgo. O filho desse casamento viria a ser Carlos I da Espanha. Nascido nos Países Baixos, herdou por parte de seus avós maternos o Reino da Espanha (1516-1556) e da parte de seus avós paternos a Holanda, a Áustria, a Sardenha, a Sicília, o reino de Nápoles e o Franco-Condado. Foi eleito o Sacro Imperador Romano, passando a chamar-se Carlos V. Em 1556, o rei da Espanha abdica o reino em favor de seu filho Filipe II, que se torna o responsável por tentar em vão abafar uma oposição protestante nos Países Baixos, em 1568 começa a "Revolta Holandesa", também conhecida por "Guerra dos 80 anos", depois de massacres mútuos entre calvinistas e católicos, foi proclamada a República das Províncias Unidas dos Países Baixos em 1579 com a União de Utrecht e a União de Arras, que eram as províncias do sul que ficaram sobre o domínio espanhol. "No início do século XVII, essa nação de apenas 1,5 milhão de habitantes já praticava as mais inovadoras técnicas comerciais e financeiras da Europa" (PERRY, 2002: 254). Durante as 
décadas posteriores, a Espanha realiza apreensões de embarcações holandesas no porto de Lisboa: "Em 1685, Filipe II mandou confiscar os navios flamengos (holandeses) ancorados em seus portos. O mesmo fez em 1690,95,99" (ABREU, 2000: 103).

As relações comerciais entre Holanda e Portugal eram muito intensas. Nas praças de Roterdã e Amsterdam a presença de mercadorias comercializadas por intermédio dos portugueses era muito grande e supõe-se mesmo que se haja intensificado com a emigração judaica decorrente das perseguições. Esses comerciantes não só introduziam na Europa Central as especiarias trazidas do Oriente pelos navios lusitanos como, por usa vez, os armadores holandeses realizavam habitualmente operações triangulares, levando mercadorias da Europa para trocar por escravos na África e, de posse destes, conduzindo-os até o Brasil para nova permuta. Nesta vasta rede é que se teria introduzido o açúcar. Diz-se mesmo que a frequência das embarcações holandesas (as urcas) era tão grande, no Rio de Janeiro, a ponto de ter influído na denominação de um acidente geográfico (o morro da Urca) (...). Com a perda da independência de Portugal, a nova casa Real espanhola logo terminou, em 1585, o confisco e apresamentos de navios flamengos (holandeses) que se encontrassem em seus novos domínios, tanto na Europa como na África, na Ásia e na América (PAIM, 2000: 78).

Até a União Ibérica, tanto em Portugal quanto na Espanha, mas especialmente em Portugal, estruturou uma elite comercial de origem judia. Em muitos reinos europeus, era permitido ao judeu exercer apenas a função ligada ao comércio, pois ao católico não era permitida a usura. Segundo PAIM (2000), a nobreza europeia não podia dedicar-se a atividade comercial sob pena de perder privilégios, "os católicos acabaram deixando historicamente aos judeus do comércio e das transações relacionadas a empréstimos" (Ibidem, 2000: 69).

Com a Inquisição Portuguesa e a conversão compulsória em 1497, decretada pelo rei D. Manuel, obrigando à mudança de nomes dos judeus, que passaram a ser chamados de cristãos-novos, muitos judeus portugueses (sefaradita) se espalharam por várias cidades onde floresceu 0 comércio e a economia financeira; os que ficaram e mantiveram suas práticas escondidas e ficaram conhecidos como judeus marranos, "os judeus portugueses se transferem para outros países, onde acabaram assumindo uma posição de destaque no que se poderia denominar de mundo financeiro" (Ibidem, 2000). Eles migraram para a região dos Países Baixos, onde floresceu 
a economia financeira; para Espanha, tornando uma alternativa ao crédito dos banqueiros genoveses, cuja Espanha tinha um elevado saldo devedor, além de comprar ouro e prata no atacado em Sevilha e distribuir por todos os mercados mais importantes, onde se negociavam metais preciosos na Europa, como a Antuérpia por exemplo. A migração destes judeus marranos foi tão importante que uma das políticas manuelinas foi a proibição da saída de membros desta comunidade, fechando assim os portos portugueses para ela.

Segundo José Antônio Saraiva (apud PAIM, 2000), a união ibérica facilitou o trânsito desses financistas portugueses para corte espanhola. Houve uma migração maciça, pois o império espanhol oferecia uma vasta oportunidade de negócios - prata e ouro dos Americanos, açúcar e madeira brasileira, escravos africanos, sal e peixe português, especiarias orientais dentre outras.

\begin{abstract}
De Madrid, de Sevilha, de Alicante, os 'portugueses', nome que quase se tornou sinônimo de 'judeus', dominavam parte do comércio com as Índias Orientais, davam trânsito à prata da América para fora da Espanha, forneciam empréstimos à Coroa, arrendavam numerosíssimos contratos e monopólios do Estado. Também na América espanhola ocuparam posições econômicas dominantes, no comércio de escravos, do açúcar. Em resultado dessa migração em massa é que o número de processos inquisitórios volta crescer em Espanha e seu império, a partir do século XVII e sobretudo a partir de 1620 (SARAIVA apud PAIM, 2000:70).
\end{abstract}

Segundo Boyajian (apud PAIM, 2000), em seu livro "Portuguese bankers at Cort of Spain: 1620-1650", um grupo de famílias de "cristãos-novos" portugueses e espanhóis (Angel Caldera, Coronel, Frias de Salazar, Gomes de Elvas, Mendes Rodrigues de Elvas, Veiga Rodrigues Solis e Ximines de Aragão) conseguira escapar da perseguição em Portugal e Espanha. Por volta de 1580 este grupo dominava o comércio de especiarias no Atlântico ramos dessas famílias estavam espalhadas pela Antuérpia, Florença e Veneza "onde praticavam o comércio e participavam de operações comerciais e financeiras em conjunção com outros proeminentes portugueses e flamengos (holandeses)" (ibidem, 2000).

Como os grupos das famílias de judeus portugueses tinham como tendência apoiar os Países Baixos pela tolerância religiosa e por ter a 
organização administrativa mais moderna, então o Conde Duque de Olivares ${ }^{31}$ em 1620 incentivará a aproximação dos banqueiros portugueses - que nesse momento já não se interessavam mais pelas especiarias devido a grande concorrência e concentravam seus investimentos na indústria açucareira - à Corte espanhola. Portanto, em termos financeiros, a política de Olivares, ao proteger os banqueiros portugueses, rachou o grupo financeiro destas famílias que participavam de um comércio parceiro - mesmo com toda a política de bloqueio espanhol à Holanda -, ao mesmo tempo, que possibilitou respirar diante dos imensos déficits criados pelas constantes guerras que a Espanha se metia para defender seus parentes austríacos na Europa. Seus principais credores eram os banqueiros genoveses.

Nenhuma política agressiva, de Filipe II contra os Estados protestantes e judeus, foi capaz de dar a hegemonia do poder mundial para Espanha, glorificando a igreja católica; "o grande ideal de Filipe II, é sabido, entretanto, foi sobretudo o domínio religioso" (HOLANDA, 1989: 178), muito pelo contrário, apenas acentuou mais a dívida com os credores europeus e sua luta contra os inimigos da fé católica nos Países Baixos acelerou e, até mesmo, provocou o processo de Independência das sete Províncias Unidas. HOLANDA (1985: 178) realiza a seguinte indagação: "Não estaria de certa forma ligado este combate ao fato material de recrutarem-se, entre judeus, cristãos e banqueiros da burguesia protestante, os principais credores ou 'fautores' do desiquilíbrio econômico da Coroa espanhola?" A região dos Flandres ficou sobre o domínio espanhol sofrendo com as perseguições religiosas.

A guerra contra os holandeses, do ponto de vista financeiro, foi a luta de dois grupos oriundos do mesmo tronco familiar que com a migração forçada, ao longo do século XV, XVI e XVII, espalharam-se pelos Flandres e Países Baixos; foram separados pela conjuntura Geopolítica e financiaram o

${ }^{31}$ In: PAIM (2000), "Momentos decisivos da história do Brasil". São Paulo. Martins fontes.74p.

Olivares (Gaspar de Guzman, 1587-1645) ingressou na Corte em 1616, como secretário de Estado, ainda sob Felipe III (1578-1621), cujo reinado iniciou-se em 1598. Sua proeminência ocorreria entretanto sob Felipe IV, que começa a reinar com apenas dezesseis anos em 1621, sobre quem desde então Olivares adquirira incontestável ascendência. Em 1625, a Coroa agraciou-o com o título de Duque de São Lucas. Sendo, por herança, Terceiro Conde de Olivares, tornou-se comum denomina-lo de cond-duque. Como talvez a figura mais relevante do mundo político no século XVIII, J. H. Elliott (...) o comparou ao grande rival, o cardeal Richilieu (1585-1642). 
Estado, no caso espanhol, e as Companhias de Comércio, no caso holandês, para tentar monopolizar o negócio mais lucrativo que estava ao seu alcance, o açúcar. É fato que os judeus portugueses não eram uma população grande na produção do açúcar. Entretanto, entre os engenhos que tinham judeus marranos como donos, representavam menos de $7 \%$ no Brasil holandês. No entanto, essa comunidade representava "um papel muito mais importante como financiadores da indústria açucareira, corretores e exportadores de açúcar, bem como fornecedores de escravos negros a crédito, aceitando açúcar em pagamento" (WIZNITZER apud PAIM, 2000: 77).

A guerra de corso e o sal do Caribe foram as alavancas iniciais da navegação batava no Novo Mundo. A essa altura, contudo, o açúcar brasileiro passara a representar não um negócio propriamente holandês, mas uma atividade eminentemente controlada pela comunidade sefaradita de origem portuguesa estabelecida em Amsterdã para fugir à perseguição do Santo Ofício na península lbérica e à reconquista pela Espanha do porto de Antuérpia, que constituiu até 1585 o grande entreposto português no norte da Europa. (MELLO, 2010:12)

A política de Olivares, que começa com Filipe III e fica mais forte no reinado de Filipe IV prefere, ao invés de usar a força (hard-power), usar a política da persuasão acolhendo para as finanças espanholas os banqueiros portugueses, essa política é a maior evidência dos sinais da decadência do hard power do até então glorioso império espanhol.

Desde o começo, Olivares interessa-se diretamente pelas finanças da Coroa, e logo estava pessoalmente envolvido no laborioso encargo de negociar os contratos anuais com os banqueiros reais. A maioria era constituída de financistas genoveses que, segundo a opinião corrente, levavam a Coroa ao pagamento de multas devido a exorbitantes taxas de juros. Olivares concluiu que a salvação financeira dependia de sua habilidade em quebrar as garras sufocantes dos genoveses e traçou planos para alcançá-la. Logo em 1626 fez uma clara limpeza no Conselho de Finanças, cujos membros estavam marcados por sua estreita associação com os genoveses, e colocou à frente do novo Conselho um ministro em quem tinhas inteira confiança, Gilimon de la Mota. Na comunidade econômica portuguesa - integrada por muitos membros de origem judaica, ansiosos por proteção contra as atenções da Inquisição - encontrou um grupo financeiro potencial alternativa para Corte contra os genoveses, em troca da 
proteção real, foi capaz de suspender os pagamentos aos banqueiros em janeiro de 1627, convertendo em longo prazo dívidas de curto e forçando a redução dos juros (ELLIOT apud PAIM, 2000: 75).

Segundo PAIM (2000), ao conquistar um lugar ao sol na corte espanhola os banqueiros portugueses consolidam sua posição no império. "Deste modo, se bem que não diretamente, a Corte de Filipe IV terá dado um poderoso impulso para o sucesso açucareiro no Brasil". (Ibidem, 2000:76). Segundo Holanda (1989:178), Braudel chama atenção para o fato de que a união ibérica constituiu uma espécie de marco na orientação da política espanhola em direção ao Atlântico.

Essas informações são relevantes para $\circ$ entendimento do conflito, pois dessa forma, temos respondido a seguinte pergunta: quais eram os interesses financeiros? A quem interessava comercialmente essa guerra? Quem lucraria com o monopólio do negócio do açúcar? Os bons ventos do business sopraram para os holandeses no final das contas, pois eles quebraram o monopólio português e enfraqueceram a Espanha no Atlântico, sufocando o império espanhol como uma jiboia ao tirar o último suspiro das finanças dos habsburgos espanhóis, o açúcar português. Como os holandeses controlaram o Atlântico Sul por quase três décadas, o império espanhol não resistiu e em 1640 ocorre a Restauração da Corte portuguesa com apoio holandês. Em 1648 a Espanha é derrotada na Guerra dos Trinta Anos. Os acordos decorrentes do final desta guerra, como a Paz de Vestfália iriam abolir a ideia de Mar Fechado (Mare Clausum) e reconheceriam a ideia de Razão de Estado e de reciprocidade.

Segundo LEVY (2008), com a Restauração da corte, a Inquisição portuguesa perseguirá ainda mais ferozmente os judeus marranos no Brasil e em Portugal. Os de Recife migram para Nova Amsterdam e fundaram uma cidade na ilha de Manhatam, onde hoje está assentada a cidade Nova York, os judeus portugueses foram pioneiros na colonização deste local, sendo em grande parte, responsáveis pela inauguração da bolsa de negócios.

Perseguir os judeus portugueses, politicamente, significava para D.João IV de Bragança se eximir das dívidas dos credores dos dois lados: 
tantos os credores holandeses, quanto os portugueses que estavam na corte espanhola. Com essa política, Portugal tentava reaver uma posição no Atlântico Sul, nada parecido com que foi o apogeu de seu império marinho do século XVI.

Quanto à sua presença direta como senhores de engenho, talvez a amostra não represente a situação que de fato se configurou depois da Restauração, quando a indústria parece alcançar grande esplendor, à luz dos dados relativos ao crescimento do número de engenhos, transcritos ao considerarmos a questão. O próprio Wiznitzer identificou grande número de judeus entre os senhores de engenho, presos no Brasil e queimados pela Inquisição, na primeira metade do século XVIII (PAIM, 2000:77).

Doravante, o último aspecto desta introdução: o Geoestratégico. Porque se é fato que a política da Holanda (Países Baixos) conseguiu quebrar o monopólio português do açúcar branco e enfraqueceu definitivamente o império Habsburgo da Espanha, também é fato que a política espanhola conseguiu manter uma posição relativamente importante no Atlântico Sul, e depois da Restauração a política portuguesa foi capaz de manter o território sul-americano pelo menos até a independência do Brasil em 1822 e depois segurou suas colônias até, perdê-las, definitivamente, na segunda metade do século XX, desta forma, colocando ponto final na dominação portuguesa no Atlântico Sul.

\footnotetext{
Fora de dúvida está que todo este movimento de conquista e penetração está previsto na legislação filipina. Está ainda perfeitamente enquadrado no esquema da colonização preconizada e realizada pela Espanha na América. Além disso, decidiu-se no Nordeste a posse efetiva do território luso na América durante o período espanhol. Foi de lá expulso o francês, como seria mais tarde o holandês (HOLANDA, 1989: 186).
}

O Nordeste brasileiro é como uma chave na rota do Atlântico Sul. As correntes marítimas favorecem a aproximação a costa e os ventos são favoráveis durante seis meses, o que facilitava a chegada de barcos que tinham como destino o oceano Índico. Portanto, o nordeste brasileiro, que lembra uma península, é um ponto estratégico excepcional para distribuição das mercadorias que passavam pelo Atlântico Sul e iriam para Europa. O Brasil 
significava, numa escala global, o que Portugal significou no período da renascença: ambos representam uma alça para se chegar ao mercado mais importante. Existia uma rota secundária para que as mercadorias chegassem aos Flandres, no final da Idade Média, era via marítima e esses barcos tinham como parada o porto de Lisboa antes de chegar no mar do Norte.

O Brasil tinha esse significado geoestratégico e, claro, ainda tem, só não somos rota obrigatória de passagem de quase todos os barcos do mundo, pois não temos infraestrutura portuária para receber as embarcações. O Brasil sempre foi visto como uma ligação natural entre o Atlântico Sul e Norte; era, no século XVII, muito mais seguro fazer essa ligação (norte-sul) pelo Brasil do que pelo Caribe, este último é um mar mais revolto e por ser formado por inúmeros arquipélagos favorecia a atividade corsária, os holandeses foram os que mais usaram essas características para piratear os produtos espanhóis no Caribe (ou Antilhas), boa parte dos investimentos da máquina de guerra criada pela Companhia das Índias Ocidentais (WIC) veio do corso realizado nas águas do Caribe, embora os holandeses tenham capturado muitos barcos portugueses e espanhóis no Atlântico Sul, não foram raras as vezes que os comboios espanhóis, com barcos abarrotados de açúcar, alcançaram a metrópole espanhola.

Os holandeses perceberam as vantagens geoestratégicas do Pernambuco e logo que invadiram a Bahia viram que não seria fácil dominá-la e sua posição não era tão vantajosa quanto das costas pernambucanas. A capitania de Pernambuco não tinha fortalezas tão resistentes e a organização para defesa era precária, além da excelente posição dentro da rota comercial, seria a base pela qual a Holanda conseguiria facilmente penetrar por todos os domínios portugueses ultramarinos.

Em 1595, mercadores de Amsterdã arriscaram a primeira viagem ao oceano Índico, viagem demorada, de pouco proveito imediato, mas fecundíssima em consequências, pois logrou a certeza da fragilidade do domínio peninsular naquelas regiões alongadas. Da mesma cidade partiram outros navios em maio 1698, terceira expedição em abril, quarta em dezembro de 1599. Em várias províncias surgem negociantes arrojados, improvisam-se companhias opulentas, ávidas de despojos e aventuras no amplo teatro que se abria. A emulação salutar ameaçava o perigo; 
intervieram os Estados Gerais, e por meio de concessões e privilégios conciliaram as pretensões divergentes, fundando a Companhia das Índias Orientais no começo de 1602. (ABREU, 2000: 104).

A guerra entre Espanha e Holanda prejudicava os negócios portugueses, a fome e os prejuízos se tornaram insustentáveis até que chegou num ponto que em 1609 se estabeleceu uma trégua de doze anos, "tornara-se de tal modo indispensável para economia portuguesa a navegação dos holandeses, que os Reis da Espanha cederam aos protestos dos mercadores" (HOLANDA, 1989: 235). Nessa trégua, os negócios da Companhia das Índias Orientais só aumentaram e, durante a trégua, a elite mercantil holandesa retoma o comércio luso-português, "com a assinatura da Tégua dos Doze Anos (1609-1621) o comércio luso-holandês reiniciou-se sem empecilhos e foi durante esse período que se intensificou o interesse da Holanda pelos gêneros do Brasil" (Ibidem, 1989).

No decurso desses anos, cerca de 50 mil caixas de açúcar, equivalentes grosso modo a 1 milhão de arrobas, desembarcavam anualmente nos portos das Províncias Unidas, suprindo nada menos que 29 refinarias. Graças à regularidade e frequência desses contatos, dispunha-se na Holanda de um excelente conhecimento não só das condições econômicas e sociais, mas também do litoral do Nordeste, dos seus portos e até do traçado urbano de Olinda, conhecimento indispensável à preparação e à execução dos ataques primeiro contra a Bahia e depois conta Pernambuco.

A elite mercantil holandesa convenceu os Estados Gerais (assembleia máxima das Províncias Unidas dos Países Baixos) a criar uma Companhia de Comércio nos moldes da primeira, mas, para explorar o Novo Mundo, e dar o suporte logístico para os negócios do oriente, essa seria a Companhia das Índias Ocidentais (sigla internacional WIC). A ideia seria disputar com a Espanha a área de influência do Império marítimo português na rota para o Oriente via Atlântico. A WIC seria responsável pelo Atlântico Sul e Caribe e suas ações de intervenção eram feitas a partir de uma organização militar que tomava os portos e enclaves mais importantes da coroa portuguesa, além de realizar o corso em todas as águas. O suporte ideológico desta expansão, ou seja, o "destino manifesto" neerlandês foi escrito por Hugo 
Grotius "Mare Liberum" (1609) no qual se defende a ideia de que os mares não poderiam ser divididos entre duas nações e, sim, deveria ser daqueles que possuíssem capacidade e força para controlar as diferentes rotas comerciais.

\section{A Companhia das Índias Ocidentais (WIC): Mare Liberum, guerra e comércio.}

Como nos lembra, MELLO (2010), a WIC não era fruto de uma conspiração de portugueses sefaraditas, embora a política desta companhia os favorecessem enormemente. Ademais, a empresa neerlandesa era controlada e administrada por protestantes calvinistas que queriam entrar no negócio de açúcar visto que nos anos de trégua o fluxo de mercadorias vindas do Brasil havia aumentado muito. A estratégia desenvolvida por esta empresa militar é dominar os entrepostos comerciais portugueses além-mar e estabelecer 0 monopólio desta rota comercial. Os comerciantes de Amsterdam não eram tão inclinados à guerra, mais moderados, criavam políticas que atrapalhavam a companhia comercial, "a tensão permanente entre esse grupo, que pode ser referido como um partido da guerra, e os interesses comerciais de Amsterdã, sempre inclinados a moderação" (MELLO, 2010:14). Era mais interessante, para Amsterdã, o restabelecimento das relações formais e o fim da guerra, pois, em caso de confronto, os custos eram sempre muito mais altos do que os ganhos e esta rica cidade mercantil era quem arcava com os custos desta expansão comercial.

De acordo com MELLO (2010), duas questões são centrais para que seja possível entender o conflito em solos do nordeste brasileiro: "Por que o Brasil?" "Por que o Nordeste?" Primeiramente, porque a América portuguesa representava para Coroa espanhola um dos inúmeros problemas de seu império e na ordem de importância não estava entre as principais urgências militares de Madrid, "A América portuguesa constituiria o elo frágil do sistema imperial castelhano, em vista de sua condição de possessão lusitana, o que conferia à sua posição subalterna na escala de prioridades de Madrid" (ibidem, 2010: 29). O açúcar da cana e o pau-brasil proporcionavam a obtenção de lucros fabulosos, "a colônia renderia anualmente cerca de 8 milhões de florins" (Ibidem, 2010: 29); As possessões espanholas na América do Sul estavam 
localizadas em sua grande parte nos altiplanos andinos, o que dificultava o acesso ao poder naval batavo, já os núcleos portugueses estavam na costa, o que facilitava a operação naval; a posição do nordeste, que como já foi dito e de acordo com MELLO (2010), "poderia proporcionar excelente base de operação contra a navegação espanhola no Caribe" (ibidem, 2010:29).

MELLO (2010) apresenta um folheto original que circulava em Amsterdã em 1624, escrito por Jan Andries Moerbeeck intitulado "Motivos por que a Companhia das Índias Ocidentais deve tentar tirar ao rei da Espanha a terra do Brasil", no qual o autor ressalta a fragilidade das fortificações e os lucros que poderiam ser obtidos, "a Bahia e Pernambuco não dispõe de forças consideráveis ou fortalezas, de modo que, com a graça de Deus, os mesmos poderão ser ocupados" (apud MELLO, 2010:30). Neste folhetim é ressaltada a produtividade açucareira, "podem anualmente ser trazidas para cá e aqui vendidas ou distribuídas 60 mil caixas de açúcar" (ibidem, 2010:30). Pode-se perceber neste documento o caráter beligerante do empreendimento, "pois durante a pilhagem dos habitantes por parte dos soldados e marinheiros, tudo isso se reverteria à Companhia" (ibidem, 2010: 31), e a questão geoestratégica em relação ao embate em domínios castelhanos. Moerbeeck percebe a importância financeira do Brasil para o rei da Espanha sendo um ataque que afetaria os rumos da política espanhola, especialmente a política do condeduque Olivares, que se aproximava dos banqueiros portugueses, como uma alternativa de crédito ao império de Espanha.

O Rei da Espanha, o clero e os negociantes particulares de Portugal têm naquele país grandes capitais consistentes de terras, rendas, empréstimos sobre plantações, assim como mercadorias (...). Assim, elas podem ser atacadas, confiscadas e conquistadas pela Companhia das Índias Ocidentais (apud MELLO, 2010:30).

A questão da posição geográfica privilegiada do nordeste é ressaltada por Johan Nieuhof como destaca MELLO (2010), "a exportação do açúcar do Brasil para a Europa e para África faz-se com mais facilidade que de qualquer outro ponto das Índias Ocidentais, graças à posição geográfica do Brasil" (apud MELLO, 2010:33). O Nordeste brasileiro está no ponto mais oriental da América do Sul facilitando a chegada de quem vem do sul da África para Europa ou de quem faz o caminho inverso. Outro ponto importante, é que 
os holandeses já tinham em seu conhecimento bons produtos cartográficos da costa brasileira, as coleções de Markgraf e Vingboons. Os holandeses tinham informações valiosas de Olinda, Recife, Salvador. "A Bahia e Pernambuco foram assim desde o começo os alvos prioritários do ataque neerlandês" (MELLO, 2010: 39). A WIC preparou uma expedição "sob o comando do Almirante Jacob Willekens, cujas instruções determinavam que, tomada a Bahia, atacasse Pernambuco" (ibidem, 2010:39).

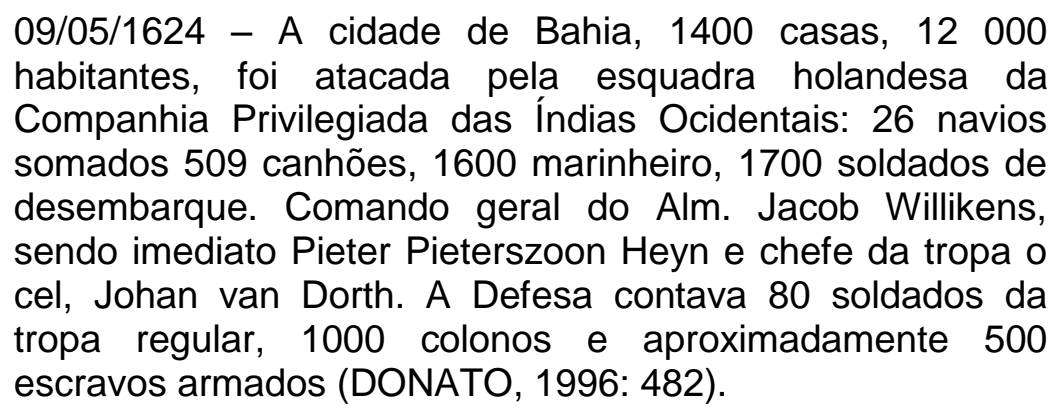

Os holandeses conquistaram facilmente 0 porto, mas não conseguiram penetrar no território, sempre sendo "encurralados pelas guerrilhas luso-brasileiras do Arrail do Rio Vermelho, (...), sob chefia do bispo D. Marcos Teixeira, e depois, de D. Francisco de Moura" (MELLO, 2010: 40). Os holandeses acharam que iriam conquistar a capitania prontamente ao dominar sua capital, assim a Armada de Willikens partiu para costa Atlântica da África, com a finalidade de tomar os enclaves lusitanos. Na Bahia, ficou o destacamento comandado pelo Cel. Van Dorth com aproximadamente 1700 soldados, este era responsável por consolidar e estender o domínio, entretanto, o coronel morreu numa emboscada e, depois, sem um comando forte e com a ação da grande Armada Luso-espanhola do comandante D. Fradique de Toledo, "na qual se alistou boa parte da nobreza lusitana, reconquistou Salvador a 30 de abril de 1625" (Ibidem, 2010:40). Essa armada era composta de diversas armadas e esquadras: Armada de Portugal (22 navios, 4.348 homens de guerra e mar, 384 peças de artilharia); Armada espanhola do Mar Oceano (11 navios, 2.516 homens de mar e guerra, 269 peças de artilharia); Armada espanhola do estrito de Gibraltar (5 navios, 1490 homens de guerra e mar, 158 peças de artilharia); Esquadra espanhola de Vizcaya (4 navios de guerra, 1181 homens de mar e guerra, 108 peças de artilharia); Esquadra 
espanhola das Cuatro Villas (6 navios de guerra, 1845 homens de mar e guerra, 154 peças de artilharia; Esquadra espanhola de Nápoles (4 navios de guerra 1583 soldados, 114 peças de artilharia).Total de 52 navios de guerra, 18 transporte, 12.566 homens de mar e guerra e 1185 peças de artilharia.

Essa pesada Armada luso-espanhola, além de ser bastante poderosa, podia se deslocar no oceano com uma vantagem em relação ao socorro a ser prestado pela metrópole holandesa a praça conquistada na Bahia. Os barcos holandeses ficavam presos durante os três meses de inverno no mar do norte, enquanto os luso-espanhóis saindo do mediterrâneo não tinham este problema, podendo prestar socorro prontamente. Embora, mais tarde quando os holandeses invadem o Pernambuco a ajuda espanhola não chegou a tempo como outrora, pois a conjuntura não permitia a Coroa da Espanha organizar uma poderosa armada como acontecera em 1625.

Tudo indicava uma derrota decisiva da Companhia da Índias Ocidentais na América do Sul. Entretanto, em 1628, o então almirante Pietr Heyn organiza uma frota com 20 naus com a intenção de aprisionar a famosa frota de prata espanhola que saía com regularidade do Caribe em direção a Espanha. Junto com o almirante Heyn estava o almirante Hendrick Corneliszoon Loncq. Ambos comandavam uma força de mais de 600 peças de artilharia e 4000 mil homens. O aprisionamento da Frota de Prata ocorreu no dia 8 de setembro de 1628, que renderam a Companhia das Índias Ocidentais a alta soma de 13 milhões de florins. com parte da renda foi financiada uma nova operação de invasão ao Brasil, depois de deduzidas as comissões dos diretores (70 mil florins), a comissão dos dois comandantes (7 mil florins), a divisão de $50 \%$ da presa com os acionistas da WIC, bem como o soldo dos dezessete meses para os oficiais e marujos, restavam nos cofres da Companhia das Índias Ocidentais cerca de 1,5 milhão de florins para 0 financiamento de novos projetos expansionistas, entretanto os neerlandeses não iriam tentar a Bahia novamente, mas sim uma praça com menos fortificação e mais conhecida e tão rica quanto, o Pernambuco.

Segundo BOXER (1961), costumamos saber muitas informações dos figurões da Companhia das Índias Ocidentais: suas aparências, como era o comportamento de alguns e até mesmo opinião deles em algumas questões 
conjunturais. Enquanto as personagens do mundo lusitano nos são sempre cheias de mistério e imaginação, as referências iconográficas não são tão vultuosas quanto a dos holandeses. "Sabemos (...) como eram Piet Heyn, Hendrick Loncq e muitos outros figurões holandeses. Mas os portugueses foram singularmente mudos a este respeito" (ibidem, 1961: 53), entretanto, temos referências documentais importantes que nos dão excelentes referências históricas.

Matias de Albuquerque, que fora governador da capitania de Pernambuco entre 1620-27, enquanto estava na Europa seu irmão Duarte de Albuquerque, era no Brasil o capitão donatário de Pernambuco. Como Matias tinha uma enorme experiência no Brasil, sempre alertando as autoridades dos saques dos piratas holandeses e muitas vezes organizando a parca defesa por de trás das antiquadas fortalezas daquele litoral, "foi Matias de Albuquerque nomeado governador e comandante supremo das quatro capitanias nordestinas - de Pernambuco, Itamaracá, Paraíba e Rio Grande" (BOXER, 1961: 53). Ao nobre lusitano ficou a incumbência de ir para Olinda e organizar a defesa contra 0 ataque dos corsários neerlandeses.

Para defender o Pernambuco, Matias de Albuquerque não contou com uma força como a Armada de Toledo que fora enviada para libertar a Bahia e outras praças na costa africana. Nos anos de trégua, a força espanhola já estava muito comprometida na Guerra dos Trinta Anos e a nobreza portuguesa sofria anos de imensas crises devido ao corso holandês em águas do Atlântico Sul. Em outubro de 1629, Albuquerque chega no Brasil e encontra as defesas locais totalmente despreparadas e baixa mobilização popular.

A princípio dispunha ele apenas de 200 soldados e 650
milicianos; mas conseguiu arrebanhar uns 2000 homens, na
sua maioria mal armados e sem nenhum tirocínio. Havia no
porto de Recife cinquenta e seis navios mercantes; dezoito
foram mandados sem demora para Portugal, completamente
carregados de açúcar, enquanto que dezesseis dos trinta
oito restantes foram convertidos em navios de guerra
(BOXER, 1961:55).

Se não fosse esse mínimo preparo realizado pelo experiente Matias de Albuquerque, os portugueses não teriam as mínimas condições de oferecer nenhuma resistência e seriam rapidamente cooptados pelas forças 
invasoras. O que aconteceu a seguir da invasão no Pernambuco foi uma resistência do tipo guerra de guerrilha. O capitão-mor português organizou as "capitanias de emboscadas, que eram patrulhas fortemente armadas sob chefia de homens que conheciam cada polegada do terreno" (BOXER, 1961: 55). Esse seria o tipo de entrave mais comum em todo o conflito contra os holandeses. As forças eram sempre desproporcionais e o confronto direto em campo aberto favorecia as poderosas forças invasoras. Mais tarde, no começo do ano de 1631, as forças portuguesas receberam o apoio da armada de Oquendo, com um total de 56 navios, sendo que 20 de guerra e 2000 soldados que seriam divididos, sendo que metade desse contingente seria destinado ao Pernambuco.

Segundo BOXER (1961), o Conselho dos Dezenove (Heeren XIX) - instância máxima da administração da WIC - já tinha decidido atacar o Pernambuco no final do ano de 1628, até meio do ano de 1629 a companhia organizou a armada. "O comando da esquadra foi confiado a Hendrick Corneliszoon Lonq, que fora imediato de Piet Heyn no comando dos navios que capturaram a frota de prata" (Ibidem, 1961:52). Em julho de 1629, Loncq estava na região das ilhas de Cabo Verde, no natal do mesmo ano estava em São Vicente, "com os seus sessenta e sete navios, entre grandes e pequenos, a sua equipagem de mais de 7.000 homens e as suas 1.170 bocas-de-fogo" (ibidem, 1961: 52). Entre dezembro de 1630 e 1631, chegava a Recife uma poderosa esquadra - para reforçar os domínios e expandi-los - sob o comando de Pater e Thijssen, a força era composta por 19 navios e 1200 soldados

Com uma força naval e terrestre muito maior do que a dos lusobrasileiros, com mais munição e armamento não foi fácil organizar uma resistência, mas era a única coisa possível a fazer, tentar impedir a interiorização do domínio holandês na colônia, foi mais ou menos nisso que consistiu todo o embate entre portugueses e holandeses.

As dificuldades holandesas eram relacionadas ao ambiente. Os trópicos castigaram os holandeses, em seus relatos sempre mencionam o calor intenso como um fator de peso nos embates mais longos, enquanto os portugueses já estavam mais acostumados. O conhecimento do terreno atrasou a dominação holandesa, de fato os holandeses só irão começar a 
vencer a guerra em solo, quando Calabar, um homem da terra, começa ajudar as forças invasoras. Então, os holandeses conseguem destruir a resistência do Arraial do Bom Jesus e os portugueses se retiram para o sul, entre 1637-1644, - Conde Maurício de Nassau vai governar o Pernambuco, esse período é marcado por alguns confrontos náuticos e certa estabilidade. Com a saída de Nassau, começam os movimentos de insurreição, que acabam com a expulsão dos holandeses do Brasil.

\section{A guerra holandesa e a luta de resistência lusitana: análise da geografia do Brasil aplicada a fins militares.}

Como sugere MELLO (2010), esse conflito pode ser dividido em três fases: a primeira, que está relacionada à invasão holandesa e à guerra de resistência lusitana que começa em 1630, o conflito pende para o lado dos holandeses com a derrota do Porto Calvo em 1640. Com a Restauração da corte de Bragança, é realizada uma trégua de dez anos entre as nações. A partir dos anos cinquenta do século XVII, os holandeses perdem o poderoso apoio marítimo patrocinado pelas Províncias Unidas que viam em uma aliança com Portugal vantagens comerciais que o custo das inúmeras baixas na guerra contra os lusos-brasileiros não se pagavam. Depois de 1648, começam as insurreições que serão bem sucedidas, a Companhia tenta enviar seu último esforço, a última armada que caiu na Batalha de Guararapes 19 de fevereiro de 1649. Em 1652 começa uma guerra entre Inglaterra e Holanda, os portugueses aproveitam a oportunidade, reunindo uma esquadra sob o comando de Pedro Jaques de Magalhães com a missão de apoiar os insurretos e dominar o mar, assim tirando dos holandeses a esperança de resistência. Em 26 de janeiro de 1654, as últimas fortificações holandesas capitularam e o Nordeste voltou ao domínio da coroa portuguesa. Doze anos mais tarde, as Províncias Unidas reconhecem a derrota e a perda do território e assinam a paz com Portugal.

Esse conflito envolveu outras forças, além de portugueses e holandeses. Do lado dos holandeses, estavam protestantes de diferentes nacionalidades, os franceses, por exemplo, venderam informações e aproximaram os índios tapuias dos holandeses, isto ajudou a estender a permanência dos batavos na região. Do lado dos portugueses, contavam 
espanhóis, um batalhão napolitanos comandados por Bagnuolo, os índios Comandados por D. Filipe Camarão, e os negros e mulatos comandados por D. Henrique Dias, além de outros nomes que comandaram atentados e ataques contra os holandeses no período das insurreições. Essa configuração lusoespanhola continuará apenas até o início de 1641, quando chegam notícias da Restauração da Coroa Portuguesa e o fim da União Ibérica. Assim os portugueses dependem das forças que vinham da Bahia. Quando os portugueses retomaram o Maranhão conseguiram criar um corredor de ligação interno do sertão baiano ao Maranhão, de modo que com apoio marítimo da metrópole, os luso-brasileiros conseguiram estabelecer o pleno domínio territorial, enquanto os holandeses estavam ilhados nos portos que dominavam.

A estratégia da guerra de guerrilha e como os portugueses souberam usá-la é algo que aparece em quase todos os comentaristas do conflito. Foi sempre alternando tentativas consistentes, com ataques furtivos para estressar o inimigo. A violência existiu dos dois lados, isto é bem certo, mas os portugueses sempre foram reconhecidos pela forma pouco gentil de tratar os seus inimigos. Os holandeses se sentiam como figuras exóticas dentro deste novo (bárbaro) mundo colonial.

Não eram os holandeses menos bárbaros que os portugueses, não esquecendo que a Holanda se reconhece como uma nação pirata em sua origem, sendo alguns deles verdadeiros heróis nacionais. Entretanto, a guerra de guerrilha tem características mais profundas, pois, além de outras coisas, ela é uma guerra de nervos. É comum encontrar nos estudos sobre guerras assimétricas a ideia de que o tempo está do lado do guerrilheiro, tudo que o guerrilheiro precisa é de tempo, os portugueses sabiam que não seria rápido expulsar os holandeses com as forças que tinham no momento.

O primeiro movimento é impedir o movimento do inimigo, o segundo movimento é sabotar as forças do inimigo, o terceiro movimento é fugir do inimigo evitando os embates frontais e fazendo o inimigo entrar no terreno, quarto movimento é fazer emboscadas no caminho de volta das tropas inimigas. Assim se fez a guerra: foram anos. Nos primeiros momentos do conflito o Arraial do Bom Jesus era refúgio importante de apoio aos soldados, 
pois ficava exatamente entre Olinda e Recife, deste local não era difícil realizar assaltos e emboscadas para conseguir armas e mantimentos.

Mesmo quando os portugueses perderam o Arraial e tiveram que ir para o sul, a estratégia tão pouco mudava, pois os portugueses tinham uma vantagem, o terreno. O interior do Brasil é vasto e saber se locomover por ele é uma vantagem enorme. No ponto em que o barco não consegue acertar a vantagem é de quem conhece o terreno. A "traição" do mulato Calabar, especialista na região, pois era natural de Porto Calvo, além de conhecer bem a movimentação portuguesa no território propiciou aos holandeses uma dominação mais rápida, pois já estavam os batavos a alguns anos e ainda não haviam conseguido entrar no território e dominá-lo propriamente.

Algumas batalhas são de extrema importância para a produção bibliográfica de Geografia Militar, tanto batalhas navais quanto terrestres, embora esse conflito seja importante por suas batalhas navais, o fator campo fora responsável por relatos que mostram a importância do conhecimento geográfico do teatro da Guerra.

\section{Frei Manuel Calado, "O Valeroso Lucidênio": guerra de guerrilha X guerra tradicional.}

Os relatos de Frei Manuel são bem discutidos pela historiografia que realizou um levantamento mais preciso e justo da análise das personagens do conflito. Entretanto, o interesse do presente trabalho é verificar sua leitura geográfica da guerra. O juízo de valores do cronista em questão é bem questionável, uma vez que sempre responsabiliza as derrotas em estrangeiros que compunham a constelação de forças que defendiam a colônia dos ataques batavos. No capítulo II, "no qual se trata da entrada dos Holandeses na Vila de Olinda, e como conquistaram toda a Capitania de Pernambuco, e quem foram os que ajudaram nesta empresa", realiza um relato de como os holandeses conseguiram facilmente dominar o Arrecife e como tiveram dificuldades para interiorizar seus domínios. Suas primeiras descrições contam a estratégia holandesa para dominar o porto do Arrecife, sempre ressaltando a enorme 
máquina de guerra da Companhia das Índias e a pequena força de resistência portuguesa, entretanto aguerrida.

Pelo relato de Calado, a armada apontou na região do Arrecife e se posicionou frontalmente para baía e testou o sistema de defesa local infligindo uma salva de canhões. "Veio a armada holandesa endireitando com o Arrecife, e começou a despedir tantas balas com a artilharia, que parece que choviam do mar para terra". (CALADO, 1987:50). A resistência foi tão impressionante que, mesmo com a aparente superioridade, "os holandeses começaram a combater o forte do mar, logo o Arrecife com muita artilharia, e a nossa gente (...) despediram algumas naus para o norte" (ibidem), então, os holandeses resolveram usar o Porto de Pau-Amarelo, por ter um sistema de defesa mais vulnerável e ser uma área de desembarque mais adequada, "e foram deitar em terra muita gente de infantaria no Pau-Amarelo, que é a distância de três léguas do Arrecife" (ibidem). Indicando o claro conhecimento da costa brasileira e da vulnerabilidade de seus fortes, um conhecimento de geografia militar.

Ao desembarcar suas forças, elas se direcionaram ao Arrecife a fim de abrir caminho para atracar a armada holandesa. No meio do caminho, encontraram portugueses emboscados que tentavam impedir a chegada destes ao Arrecife. A descrição desta operação está relatada por Manuel Calado, que embora não estivesse lá, deve ter tido acesso às informações do relato dos participantes, "da narrativa de Frei Manuel Calado do Salvador, que embora residisse na época em Porto Calvo, ter-se-á baseado no relato de muito de seus conterrâneos que haviam participado do acontecimento" (MELLO,2010:61).

Tanto pois que os Holandeses desembarcaram no PauAmarelo, e não acharam resistência que os reprimisse, vieram caminhando por a praia; e suposto que a de dentro do mato circunvizinho alguns valorosos mancebos da nossa gente lhe deram algumas cargas, com que lhe mataram muito de seus soldados, todavia respondendo eles com outras forças, Ihe ficou a praia desembaraçada; e caminhando por ela ao entrar no rio tapado, deixaram a praia onde os nossos esperavam, sendo guiados por dois mulatos, que certos Cristãos novos the haviam mandado; tomaram por entre um cajusal, e por um largo caminho que vem dar na vila, por junto a N. Senhora do Amparo, e por 
detrás do Colégio da Companhia. E suposto que os moradores de Pernambuco lhe fizeram ali grande resistência e houve um terrível combate, aonde perderam muita gente; todavia como traziam grande força, entraram a vila, e a ganharam: e retirando-se os poucos de nossa parte para 0 arrecife, eles o vieram seguindo por restinga da área, e com a artilharia que deitaram em terra, vieram a combater o forte Diogo Pais, e ganhando-o em poucos dias, se fizeram senhores do forte do mar, e do arrecife. (CALADO, 1987: 51)

Frei Manuel Calado exemplifica um dos significados políticos mais significativos da guerra contra os holandeses: a guerra religiosa, na qual duas diferentes culturas entram num embate. Esse conflito pode ser lido como um desdobramento dos conflitos político-religiosos vividos na Europa, A Guerra dos 30 anos (1618-1648) e a Guerra dos 80 anos (1568-1648). Segundo Mello (2010), a decisão de atacar Pernambuco foi tomada em fins de 1628 e começo de 1629, portanto dentro do contexto político destes conflitos envolvendo uma constelação de forças internacionais, muitos homens que estavam mobilizados nos conflitos europeus acabaram participando do conflito em terras lusobrasileiras. "A chefia das forças de terra fora confiada ao coronel Diederick van Waerdenburch, veterano da Guerra dos Trinta anos". (Ibidem, 2010:53).

Segundo PAULA CIDADE (1959:21), Frei procura explicar a queda em poder dos holandeses de Olinda, e de outras partes do território pernambucano, apontando os pecados dos habitantes mais destacados como provocadores da catástrofe. Quando o clérigo descreve as ações dos invasores, sempre os coloca como corruptores da verdadeira fé católica, como se segue:

quebravam em pedaços as imagens de Cristo, e da Virgem Maria, e dos outros Santos, e as pisavam com tanta coragem e desaforo, como se com isto lhe parecessem que extinguiam a fé Católica Romana, outros entravam por lógeas dos mercadores, e achando-as cheia de pipas de vinho, bebiam tanto que as ruas estavam alastradas de bêbados. (CALADO,1987:51)

$\mathrm{Na}$ sequência de seus relatos, surgem algumas descrições de como os luso-brasileiros organizaram a primeira resistência. A capitânia de emboscada comandada por General Matias de Albuquerque é bem analisada por Manuel Calado. A divisão em pequenos grupelhos que se espalhavam em 
torno das entradas da cidade de Olinda e impediam a movimentação das forças holandesas em forma de guerra de guerrilha, o que dificultou por um bom tempo a penetração e o total domínio do território por parte dos holandeses. O conhecimento do território e da sazonalidade das marés eram usados para adquirir vantagem em combate como relata o auto. Com isso segundo o próprio Frei, fez:

\begin{abstract}
uma fortaleza quase inexpugnável uma légua de distância do arrecife, e outra da vila, pouco mais ou menos, para fazer ao inimigo todo mal que pudesse, e impedir-lhe a que não saísse por terra a dentro a destruir fazendas, e matar os moradores; acabou-se a fortaleza com a brevidade, e forneceu-se com artilharia, e formou-se ali arraial em forma: logo Ihe acudiram de toda a Capitania muitos valorosos mancebos que divididos em estâncias, entre o arraial, vila, arrecife, tinham encurralado o Holandês, que não era senhor nem de sair a busca de água, nem faxina para suas fortificações, porque em saindo de suas trincheiras, logo se davam sobre eles, e os matavam, e nem senhores eram de sair da vila para o arrecife, nem do arrecife para vila, senão em grandes tropas, porque os nossos se deitavam a nado, e se era ocasião da maré vazia, passavam o rio; (CALADO, 1987: 52).
\end{abstract}

A narração deste conclave coloca a situação da seguinte forma: os holandeses veem-se obrigados a conservar armas em mãos, entrincheirados nos fortes, enquanto as forças organizadas pelo índio Camarão, que ganhou o título de Dom, e com o hábito da Ordem de Cristo no grau de Cavaleiro fazia estragos nas fileiras holandesas, mas sem mudar o panorama geral da guerra. Manuel Calado descreve a chegada do donatário e governador da Capitania de Pernambuco, Duarte de Albuquerque e de reforços que vieram com a Armada sob comando do Almirante Oquendo. "Entra em cena o Mestre-de-Campo Giovanni Vicenzo San Felice, Conde Bagnoli, com seu terço de napolitanos" (PAULA CIDADE, 1959:23). Neste período, Espanha dominava Nápoles no período hegemônico dos Habsburgos. A participação do Mestre-de-Campo Giovanni Vicenzo San Felice, Conde de Bagnoli é sempre achincalhada por Manuel Calado, embora a participação do italiano tenha sido essencial para resistência ibérica no nordeste brasileiro. Na verdade, o que está por trás de um discurso que, do ponto de vista antropológico e sociológico, era uma visão ufanista de identidade com os sentimentos da terra, do ponto de 
vista da Geografia Militar percebe-se que estamos diante de dois tipos de visões de guerra: Frei Calado, com seu ponto de vista guerrilheiro de retaguarda, e Bagnoli, um chefe militar inclinado aos métodos clássicos da guerra.

o guerrilheiro está no verdadeiro, campo de ação quando abandonado a si mesmo, armando emboscadas, caindo de surpresa sobre os inimigos descuidados que se encontram atrás da frente de combate; o soldado de escola só vê a batalha para a qual é preciso preparar-se muitas vezes pelo recuo que lhe permite evitar o choque em condições desfavoráveis. (PAULA CIDADE, 1959:24)

Segundo PAULA CIDADE (1959), esse ilustre soldado veio ao Brasil como sargento-mor do terço napolitano, comandado pelo Marquês de Cropani, integrante das forças luso-espanholas destinadas em 1625 à reconquista da Bahia. Neste episódio, esteve à frente de seus homens e teve comportamento distinto durante as operações. Após a retirada dos holandeses da Bahia, retornou a Espanha e foi promovido a mestre-de-campo, posto equivalente ao de coronel nos dias atuais. Retornou ao Brasil no dia 3 de setembro de 1631, partiu da Bahia para o norte na esquadra de D. Antonio Oquendo, assistindo a batalha de Abrolhos, travada no dia 12 de setembro do mesmo ano e a 21 de setembro, desembarcou com suas forças em Barra Grande (Alagoas). Na batalha de Mata Redonda, assume comando em chefe das forças luso-espanhola. Em 16 de abril de 1638, é pelo governo da capital colonial do Brasil do norte localizada na cidade de Salvador nomeado chefe da defesa local. Bagnoli consegue manter a cidade de Salvador livre da presença holandesa, então é elevado de conde a príncipe pelo Rei da Espanha como recompensa do serviço de defender a importante capital. Em novembro de 1639, parte da Bahia para o norte, na armada do Conde de Torre. Assiste a batalha da Ponta de Pedras, travada em janeiro de 1640. A batalha não foi favorável às forças luso-espanholas, ele regressa a Salvador e morre em agosto de 1640.

Tem-se escrito muitas fantasias a respeito desse bom soldado, inclusive quanto a seu verdadeiro nome. Escritores antigos chamam-no de Banholo, aportuguesando-o; dos modernos, muitos grafam Bagnoulo ou Bagnuoli; o Barão de Rio Branco, di-lo Gion (e não Giovanni), como se diria em 
dialeto napolitano. Não é verdade que tenha se recusado a aderir à revolução de $1^{\circ}$ de dezembro de 1640 , porque como se vê, morreu antes de ser proclamada a independência portuguesa. (PAULA CIDADE, 1959:23)

Quando aporta na região a Armada de Dom Oquendo, chegam os reforços para a resistência e se dá uma batalha, os holandeses avisados por seus espiões, resolvem interceptar a esquadra luso-espanhola. $O$ almirante holandês Pater (que Frei Manuel Calado chama pelo nome da frota Opátria) morre nesse confronto, afirma o cronista luso-brasileiro que o oficial holandês teria se suicidado, o que na verdade é pouco provável, visto que seu barco afundou incendiado no mar e as mortes por afogamento sejam mais comuns neste caso. Segue o relato de Frei Calado:

\begin{abstract}
Encontraram-se as duas armadas, e começaram a brigar parte a parte com grande coragem e resolução (...). Algum destroço houve de nossa parte, e duas naus estiveram a risco de se irem ao fundo, e dois pataxos de serem queimados, se não fora a boa diligência com que Ihe acudiu, aonde também houve alguns mortos, e feridos, que são ordinários frutos que se colhem nas batalhas, assim do mar como da terra; porém os espanhóis, e portugueses, que vinham nos Galeões com Dom Antônio de Oquendo, se houveram tão valorosamente, e com tanta fúria, e orgulho, que deitaram ao inimigo três naus no fundo, e outras destroçaram (...). Vendo-se os holandeses desbaratados, se vieram retirando para o Arrecife; e Dom Antônio se foi reparar, e tomar algumas águas na Baía de Traição; e daí foi fazendo sua viagem para as Índias, segundo o preceito, e ordem que ele trazia. (CALADO, 1987:53)
\end{abstract}

Conhecida como batalha de Abrolhos, em 12 de novembro de 1631, é considerada uma das disputas navais mais sangrentas ocorridas em águas brasileiras. No "Dicionário das Batalhas Brasileiras", de Hernâni Donato (1996), temos um panorama de quais forças estavam envolvidas no conflito, quantos homens combateram e quais era seus objetivos gerais e específicos. A seguir, temos o levantamento de DONATO (1996: 175):

Às $9 \mathrm{~h}$, em águas do Arquipélago de Abrolhos, chocaram-se as esquadras luso-espanholas, dita a Armada do General Dom Antônio de Oquendo, Almirante do Mar Oceano, e a holandesa, do almirante Adriaen Janszoon Pater. A força de Oquendo: doze galeões espanhóis e cinco portugueses, uma urca e dois patachos, totalizando 439 canhões. Em conserva, 24 barcos carregados com açúcar destinado à Europa e 12 transportes de tropas levando 1.200 soldados 
espanhóis e napolitano às ordens do Conde de Bagnouli, enviados a reforçar os insurgentes da PB e de PE. A força de Pater: treze naus e três patachos, montando 472 canhões. Oquedo saíra da Bahia no dia 3, porém fortes ventos contrários empurraram seus navios para o sul. $\mathrm{Na}$ manhã de 12, a oito léguas dos Abrolhos, pelo paralelo de $18^{\circ}$, a formação holandesa surgiu por barlavento. Iniciou-se a mais sangrenta batalha travada em águas brasileiras. Disputada durante todo o dia. Ao escurecer, os holandeses retiraram-se, tendo em comando o alm. Martin Thijszoon, pois Pater morrera no mar. Tendo repelido o ataque e ficado senhor de seus movimentos, Oquendo reclamou a vitória, embora seus barcos registrassem tantos danos quanto do adversário. Perdas holandesas: a nau capitania, Prinz Willen e a Provintie van Uttrecht, seus dois melhores navios, com 84 peças no total; 750 mortos, 350 feridos e alguns prisioneiros (...). A baixa mais sensível, a de Pater, que orgulhosamente ter-se-ia recusado a ser socorrido pelo inimigo. Anton Thysio, historiador de batalhas navais holandesas, escreveu que "abandonado o almirante perfidamente pelos seus, sucumbiu em meio das ondas, juntamente com quase um milhar dos seus homens". Perdas dos lusos-espanhóis: o barco Santo Antônio de Pádua, espanhol, e o Prazeres Menores, português, postos a pique; o espanhol San Buena Ventura, capturando, somando, os três, 66 canhões; 800 mortos e 400 feridos ou prisioneiros. O almirante espanhol Valezilla afundou com suas 700 toneladas e 28 peças, sustentara combate desigual contra a nau Vereenidge Provintien, do alm. Thijszoon, de 800 toneladas e 50 peças e o Provintie van Uttrecht, de 600 toneladas e 38 peças. Também desigual o confronto do Santiago do Leste, com 900 toneladas e 44 peças, batendo o pavilhão de Oquendo, diante da Prinz Willen, nau de 1000 toneladas e 46 canhões, e mais a Walcheren, 560 toneladas e 34 canhões. O galeão português Prazeres Menores, 305 toneladas, teve comportamento brioso e sorte fatal. Montando 18 peças, abordou a Walcheren e, repelido, ficou à matroca, indo a pique ao atravessar a proa da Santiago, da Prinz Willen e a Walcheren. Resultado estratégico: Oquendo pode desembarcar na Barra Grande a tropa de Bagnouli, a qual, marchando 200 quilômetros, entrou no arraial de bom Jesus a 12.11.

Uma leitura da geografia militar de Frei Manuel Calado pode ser feita sobre dois aspectos, esses que para o cronista foram relevantes para derrota luso-brasileira na fase das invasões. O primeiro fato foi a espionagem, cujo réu máximo era Calabar que, ao se associar ao comando holandês, possibilitou a destruição da fortificação feita por Matias Albuquerque no arraial 
de Bom Jesus, e mostrou a chave para conquista holandesa de Porto Calvo e, por consequência, do que faltava para conquista do Pernambuco.

Domingos Fernandes Calabar foi grande temor que teve de ser preso, e castigado asperamente por Provedor André de Almeida, por alguns frutos graves, que havia feito na fazenda d'el-Rei; também lhe cobrou muita afeição o General do mar dos Holandeses, que o trazia em sua companhia, para que the ensinasse as bocas dos rios navegáveis, e as paragens aonde podia deitar gente em terra, e por meio de Calabar dava muitos assaltos, e fazia muitos furtos, e vexações nos moradores que tinham em suas casas, e fazendas junto ao mar, por toda a costa de Pernambuco: chamava-se este General do mar João Cornelicen Lictart. (CALADO, 1987:54)

Outro aspecto de relevância para o estudo de Geografia Militar é sobre a avaliação que o Frei faz de Bagnoli. Para o luso-brasileiro, o caminho para se conduzir a guerra era a guerrilha e não o uso dos estratagemas clássicos de guerra, pois, frente a frente, os holandeses eram insuperáveis, tinham mais homens e armas, sem contar em avançadas técnicas de combate. Tanto no mar quanto da terra, há que se destacar que a revolução militar do século XVII ocorrera nos Países Baixos ${ }^{32}$. Nesse sentido, que o cronista exalta muito D. Filipe Camarão, o batalhão de índios. Seu estilo de combate consistia em atacar por emboscada, guerra de movimento. Nesse caso, fica claro o julgamento de Calado quando descreve a ação de Conde Bagnouli no ataque holandês a Porto Calvo.

e requerendo os moradores ao Conde que lhe mandasse fazer uma emboscada em um atalho por onde sabiam que 0

\footnotetext{
${ }^{32}$ ROTHENBERG, G. E. "Maurício de Nassau, Gustavo Adolfo, Raimondo Montecuccoli: 'Revolução Militar' do século XVII". In: PARET, P. "Construtores da Estratégia Moderna". Tomo 1. BIBLEX, Rio de Janeiro, 2001. (58p.):

Mesmo assim, a ênfase de Maquiavel na disciplina baseada numa cadeia de comando hierárquica, nas designações por funções e na competência militar obtida por constante instrução e adestramento - todas implícitas em sua defesa do sistema de legião romana -, exerceu influência considerável na criação de forças eficazes de combate, mas também controláveis, durante a Guerra dos Oito anos nos Países Baixos. A oligarquia que governava o país estava preparada confiar em seus comandantes, príncipes da casa de Orange-Nassau, a organização de um exército baseado em novo modelo. Como outros soldados bem instruídos da época, os príncipes de Orange eram familiarizados com textos militares dos autores antigos, mas também reconheciam que, para obter os máximos benefícios possíveis da combinação de mosquetes e piques, era necessário mais instrução e novo grau de controle, aliados a um novo estilo de liderança em combate. Para produzir o máximo em termos de fogo e movimento, a infantaria não mais podia ser concentrada em grandes formações emassadas, mas sim desdobrar-se progressivamente em unidades menores, o que requeria oficiais e ao mesmo tempo, obedecessem a um plano geral de batalha.
} 
inimigo havia de vir secretamente, ele não quis, senão esperá-lo na mesma povoação para ali chocar com ele" (CALADO, 1987: 57).

Finalizando o relato da tomada de Porto Calvo, o Frei relata o julgamento e a morte de Calabar e a retirada do General Matias de Albuquerque e de seu irmão Duarte de Albuquerque Coelho, que foram para Alagoas se juntar com o Conde Bagnoli para reestruturar a resistência e tentar alguma investida contra a potente máquina de guerra holandesa. A esperança vem com a chegada de Dom Luiz de Roxas e Boria, com um contingente de 1.500 a 2000 homens, entre espanhóis e portugueses, segundo o julgamento de Manuel Calado, "muitos dos quais eram bisonhos, e os outros já práticos, e experimentados na guerra, que já eram soldados".

Depois da derrota das forças ibéricas de Porto Calvo, o Padre Manuel Calado é questionado sobre a retirada estratégica e sua opinião divergia muito da do alto comando. Calado acreditava que os luso-brasileiros deveriam continuar em suas terras, fazer grupo de guerrilhas e resistir à ocupação dos infiéis. O alto comando, com uma visão ligada à coroa espanhola e, assim, da União Ibérica, classificava os holandeses como revoltosos e se retiram para organizar uma contraofensiva e fortificar as praças ainda de domínio ibérico.

\begin{abstract}
Porto Calvo foi abandonado pelo exército luso-brasileiro. Em agosto de 1635, Arciezewski ocupou Peripueira, no litoral alagoano. E nos primeiros dias de janeiro de 1636, d. Luís marchou para Porto Calvo. Sabedores da sua vinda, os moradores dos arredores procuraram frei Manuel Calado, pedindo conselho acerca do que fazer sobre o edital que mandava a população retirar-se para o norte, de modo a criar, entre Porto Calvo e o Rio Santo Antônio (Peripueira), um no man's land de dez milhas que dissuadisse os ataques de campanhistas luso-brasileiros. O frade não só incitou a desrespeitarem a ordem do comando neerlandês, como também organizou e chefiou um grupo guerrilheiros locais. (MELLO, 2010:143).
\end{abstract}

A despeito do debate entre guerra tradicional e guerra de guerrilha, o Padre Manoel Calado nos dá boas razões que no cenário de guerra em questão só restara aos luso-brasileiros para lutar contra a máquina de guerra holandesa a guerra irregular. Não que a guerra irregular seja superior a guerra regular, mas que no contexto específico era o mais adequado contra os 
holandeses, eles não reconheciam as reais dificuldades de lutar no solo árido ou em climas fustigantes como é o clima nordeste e as monções de inverno que castigam o litoral no inverno, o ambiente e o tempo estavam de fato a favor dos guerrilheiros que quanto mais dificultassem a entrada dos holandeses, mais inviabilizaria o projeto holandês de se fixar no território. $O$ uso do ambiente favorável na guerra irregular, segundo VISACRO (2009:225), relativiza os aspectos puramente militar no caso da guerra irregular e ressalta 0 caráter do ambiente político e psicossocial deste tipo de luta. "Fatores de ordem histórica, cultural, econômica e psicológica determinam não só a natureza dos conflitos irregulares como também sua amplitude" (ibidem, 2009:225). Não se pode esquecer que quando se enfrenta uma força maior a estratégia prolongada é um caminho para guerra irregular, "forças irregulares procuram fazer do tempo seu principal aliado, pois, (...), não contam com os meios que lhe permitiram conduzir uma campanha rápida e fulminante" (ibidem, 2009: 243). As forças irregulares podem ficar um grande tempo sem atividades, segundo Thomas Hammes, "As insurgências são medidas em décadas e não em meses ou anos" (apud VISACRO, 2009:243).

Muito antes de qualquer grande revolução nacionalista, que irá consagrar o uso da guerra irregular, o Padre Manoel Calado já fazia o debate sobre tal, no caso da Guerra contra os holandeses em território brasileiro.

\section{Duarte de Albuquerque Coelho, Memórias Diárias da Guerra do Brasil: uma geografia militar luso-brasileira: uma visão heterodoxa, combinação entre a guerra de guerrilha e a a guerra convencional.}

O relato de Duarte de Albuquerque Coelho é apontado pelo Professor Evaldo Cabral de Mello como o mais detalhado do lado lusoespanhol da guerra de resistência, "o mais importante depoimento acerca da guerra de resistência, tanto mais que Duarte participou constantemente da refrega entre sua chegada em Pernambuco em 1631 e o sítio da Bahia em 1638" (MELLO, 2010:68). "Memórias diárias da Guerra do Brasil" é um relato que no princípio tem dados e relatos de seu irmão Matias de Albuquerque. Ele foi encarregado por organizar a resistência com parcos recursos e com a sua chegada no conflito e passa a conter seus próprios relatos, "basearam-se, 
aliás, não só na experiência do seu autor, mas também numa coleção de relações diárias que seu irmão, (...), mandou redigir" (ibidem, 2010:68).

As capitânias de emboscada foram a forma de organização de resistência escolhida pelos portugueses por não terem a menor possibilidade de um enfrentamento frente a frente. Nesse sentindo, foi de extrema importância o apoio dos exércitos dos índios, liderados por Filipe Camarão e o de negros, liderado por Henrique Dias: "haviam se somado aos guerrilheiros luso-brasileiros os índios aldeados de Pernambuco e da Paraíba" (MELLO, 2010:73) e o jesuíta paulista Manuel de Morais, "inclusive um dos que encabeçava um dos mais bem-sucedidos capitão de guerrilha da época, o jesuíta Manuel de Morais, mameluco paulista" (ibidem, 2010), que essencialmente introduziu a guerra de emboscadas no plano de operação de resistência luso-espanhol.

A estratégia dos holandeses era a de se fortificar nos pontos consolidados e expandir seus domínios colocando a indústria do açúcar a seu favor, enquanto as forças luso-espanholas tinham a missão de dificultar e prolongar o impasse. Segundo BOXER (1961), o mar domina o Brasil, uma reflexão que se impôs, mesmo com a vitória parcial de Oquendo nos Abrólhios, a missão da poderosa esquadra imperial espanhola era dar apoio a todos os portos em perigo do Atlântico Sul e do Índico, deixando as forças de resistência com um apoio marítimo muito limitado, um ensinamento histórico vital nos dias que vivemos, nos quais o Brasil busca uma projeção no cenário das Relações Internacionais e possui um litoral cheio de riquezas estratégicas: o mar domina - Brasil. "A armada de Oquendo tivera objetivos limitados, qual seja trazer reforços ao exército luso-brasileiro de resistência. Do lado luso-brasileiro, a guerra vai mudar de feição, para desgosto dos guerrilheiros" (MELLO, 2010:98).

Duarte Albuquerque Coelho era 0 capitão donatário de Pernambuco, tinha uma formação para organização das coisas públicas e da organização militar. Como fora apontado por MELLO (2010), o donatário português só vê possibilidade de vitória no teatro da guerra caso as forças luso-espanholas pudessem misturar técnicas ortodoxas (convencionais) de guerra com os métodos da guerrilha. "Para ele, a guerra volante só poderia 
constituir uma atividade anciliar da guerra principal, isto é, da guerra convencional" (Ibidem, 2010:130). Não seria possível vencer a máquina de guerra da Companhia das Índias Ocidentais que dominavam os mares e tinham um contingente de guerra muito superior em números, armamento e tinham acesso fácil aos víveres, assim como conseguiam se movimentar muito rápido com apoio logístico da frota.

A visão colocada em "Memórias Diárias", por Duarte Albuquerque, o coloca como um verdadeiro analista da Geografia Militar deste confronto. Ele faz um verdadeiro levantamento das condições dos fortes portugueses, fazendo uma análise cética sobre a defesa de Bahia e Pernambuco, as principais praças portuguesas na costa oriental do Nordeste, "se bem que fossem as principais, tinham poucos fortes, e por isso estavam expostas a serem tomadas por uma armada considerável (COELHO, 2003: 14); e da importância geoestratégica da região no Atlântico Sul, apontando três principais razões para os holandeses buscarem os entrepostos africanos como Guiné, Angola e Cabo Verde e o Nordeste (Pernambuco e Bahia): primeira razão, havia uma ligação no sistema de produção do açúcar que tinha a África fornecedora da mão de obra escrava e entrepostos comerciais e o Nordeste como área de produção; segunda razão, a Europa tinha uma grande demanda pelo produto e a Holanda basicamente era quem comercializava o produto no continente; e a terceira razão estava em poder debilitar os ganhos da Espanha e assim vencer a guerra contra os Habsbuburgos espanhóis. Assim como analisa no trecho a seguir:

Que entre todas as razões havia três muito principais para se esperar que aumentaria muito esta navegação: uma ter a que os portugueses tinham do Brasil, Guiné, Angola e Cabo verde; outra, porque de toda a Europa iriam buscar na Holanda os açúcares e os demais produtos do Brasil, assim como até então iam buscar em Portugal; e outra, porque todas as mercadorias que se levassem para a compra dos açúcares passariam à Holanda; com o que seus naturais, crescendo muito em grande benefício da Companhia debilitariam 0 poder da Espanha, faltando-Ihes este importante comércio. (COELHO, 2003: 16).

Duarte usa o inventário feito pelo seu irmão Matias de Albuquerque para explicar a situação precária da defesa de Pernambuco que 
tinha uma extensa área e com um sistema de defesa inadequado para a escala de grandeza da região ${ }^{33}$, uma região que tinha pelo menos 26 boas áreas de desembarque de tropas terrestres com quase nenhuma defesa, "Pernambuco tinha 60 léguas de costa, (...), onde o inimigo podia desembarcar; com 26 portos (...), por onde podiam entrar baixéis medianos, sem defesa alguma" (COELHO, 2003: 19) e o principal porto de Recife com poucas peças de artilharia para defesa, "tinha só seis peças de ferro, na entrada, em uma bateria incompleta, que não tinha muralha nem trincheira". (Ibidem, 2003:19).

Matias de Albuquerque realiza uma análise realista das suas primeiras ações de defesa. Primeiro, carrega toda a mercadoria de valor produzida na terra e embarca com destino a metrópole, diante das inúmeras possibilidades de desembarque que a costa do nordeste proporcionava, "No mesmo dia de sua chegada ao porto de Recife, e no seguinte, fez com que saíssem 18 navios carregados de açúcar, que estavam de partida para os portos da Espanha" (COELHO, 2003:19). A situação de defesa da praça do Recife estava em situação muito deteriorada e ultrapassada para aqueles idos do século XVII, a bateria em frente da barra, e as duas outras ao lado do forte de São João estavam demolidas. "Não só achou desta maneira aquelas fortificações, que havia deixado como convinha, mas também, pouca gente, poucas armas e quase nenhum exercício delas (Ibidem, 2003:19).

O relato de Duarte Coelho nos mostra como foram organizadas as baterias e postos de defesa para $\mathrm{o}$ ataque marítimo holandês, fortificando os pontos nevrálgicos da entrada e saída da Capitania de Pernambuco, colocando umas dos elementos, a acessibilidade, como ressaltamos adiante:

Para este mesmo efeito da defesa do desembarque em
Pau-Amarelo, deu princípio a um forte no rio Tapado, e a
outro também em frente a barra principal do Recife; ao lado
do forte da terra de São Jorge, fez duas baterias; e depois
de ir-se entrincheirando o lugar do Recife, começou outro
forte a sua entrada, como principal de toda aquela defesa;
porque aquele lugar era o porto onde desembarcavam tudo
que vinha do mar em fora, e por ele se carregavam também
todas as drogas que a terra dava de si, que não era pouco.
(COELHO, 2003:20)

${ }^{33}$ In: "Memória Diárias da Guerra do Brasil". COELHO (2003:14): aquela província excedia em grandeza à Alemanha, França, Inglaterra, Espanha, Escócia, Irlanda, e às dezessete Províncias juntas, e que os portugueses a ocupavam por espaço de mais de quatrocentas léguas de costa. 
A visibilidade e o sistema de informações aparecem no relato da organização da defesa feita as vésperas do ataque, ordenando que em toda a costa "se fizessem faróis, com gente de guarda das freguesias mais próximas, para eles ser prontamente avisado do número de baixéis que aparecessem, e de onde" (COELHO, 2003:20-21). O caráter da população, que muitas vezes aparece como aspecto psicossocial e coesão social aparecem demonstrando as dificuldades de defender o território. "Somente havia os moradores, que, por não serem soldados, nos apertos tratam somente de salvar suas mulheres, filhos, fazendas" (Ibidem, 2003:24). Esses relatos dos dão uma noção de que seria muito difícil deter o impulso batavo, como fora verificado anteriormente.

A estratégia holandesa era desembarcar armas na enseada mais segura e avançar por terra e abrindo caminho para armada fazer um desembarque em Recife. Na descrição do desembarque, Duarte Coelho, ressalta as questões das marés e as facilidades de avançar e desembarcar peças maiores na maré baixa, as peças pesadas abririam caminho para passagem de 4 mil homens 4 peças de campanha, formando quatro esquadrões de 1000 homens cada e tinham como guia um português-judeu chamado Antonio Dias Paparrobalos, como segue a sua própria análise a seguir:

\begin{abstract}
Desembarcaram, enfim, os 4 mil homens com seu general Teodoro, o qual ordenou 16 naus, barcaças e chalupas se apartassem da terra, segundo foi visto ao amanhecer. Isto era para tirar dos seus as esperanças de retirar-se, para que somente as colocassem no valor da luta. Formaram-se em quatro esquadrões da parte do norte do rio Doce, comandados pelo General, pelo tenente-coronel Enstien Calvi, pelo tenente-coronel Adolfuerlst, e pelo sargento-mor general Honox Foucques. Traziam ao todo 36 bandeiras e 4 peças de campanha. Por estar cheia a maré, não puderam passar o rio, tendo posto na boca deste três barcaças com quatro peças cada uma para assegurar-Ihes a passagem quando a maré desse lugar, e virem protegidos por elas, varrendo aquelas praias. Como guia principal traziam Antônio Dias Paparrobalos de nação hebreia, que havia estado anos comerciando em Pernambuco, e particularmente na vila, e há pouco havia fugido para Holanda. (COELHO, 2003: 32).
\end{abstract}

A descrição da desproporcionalidade das forças é sempre ressaltada por Duarte Coelho como um dos pontos centrais e por isso o uso de 
algumas artimanhas da tomada do terreno são sempre colocadas no texto, "o posto que tínhamos era encoberto a artilharia das três barcaças" (COELHO, 2003:33) assim como a disposição das armas e a ordem da primeira carga para impedir o inimigo que conseguisse ganhar terreno e ter acesso a cidade do Recife.

formou-se nossa infantaria, com as costas para mata próxima aquelas praias, e a cavalaria onde mais comodamente pudesse cerrar com as lanças que usavam, como na África, depois que o inimigo começasse a passar o rio. O mesmo fariam os índios com seus arcos e flechas" (COELHO, 2003: 32-33).

Assim que os holandeses estabeleceram o domínio dos principais portos de entrada da região, Duarte Albuquerque Coelho delineia uma detalhada descrição de como as forças luso-brasileiras se organizaram até a chegada das forças espanholas e napolitanas. A retirada para um forte que ficava entre a Praia do Pau-Amarelo e Recife e que dificultava a entrada do inimigo no terreno, associado ao uso de uma guerra assimétrica, arrastou a guerra de conquista dos holandeses por seis anos. A fortificação do Real do Bom Jesus é um ponto nevrálgico nas análises de Coelho. "O Real do Bom Jesus, em que se ia trabalhando, ficava no centro de todos estes postos, para que pudesse dar a mão a uns e outros, nas ocasiões que fossem oferecendo". (COELHO, 2003:51). A distância com o porto mais próximo dificultava manter o posto, como afirma o autor, "como este socorro e os demais que vieram aportaram onde podiam, (...) sempre ficavam longe do Real do Bom Jesus, porque algumas caravelas o faziam 60 léguas para o Norte, no Rio Grande" (Ibidem, 2003:48).

A seguir, Coelho traz da análise da Geografia Militar, da conjuntura do conflito, com os atores e seus papéis e o cenário que a luta foi travada de uma escala local para global colocando quase todas as peças do tabuleiro que terá mais de uma dimensão nas análises. O Brasil é analisado como uma cabeça de ponte para o domínio do império ultramarino. Na sua descrição ele fala das forças locais, dos mercadores, da Companhia das Índias, das Províncias Unidas e da União Ibérica. 
que o que convinha era enviar uma armada com dois mil homens e todo o necessário para eles, e alguma artilharia para conservar-se o posto do Real do Bom Jesus, por ser o mais apropriado para guerrear o inimigo e impedir-lhe as saídas que intentasse no campo; Matias de Albuquerque o fazia tão bem com tão pouca gente, com muita vantagem o faria com mais dois mil homens; que com isto se ia fazendo a guerra lenta, o que tinha muitas conveniências, porque sempre as formidáveis forças da Espanha a poderiam sustentar; que não poderia fazer assim a Companhia Ocidental, porque já com a primeira armada de setenta baixéis, e a queima do saque esperado, em Pernambuco, haviam perdido sessenta por cento do que puseram na bolsa; enquanto estivessem motivados para continuar com o excessivo gasto dos fretes dos navios, soldos de soldados, munições, abastecimentos, e tudo o mais indispensável para conservar-se, seria uma das maiores guerras; que também o era para as Províncias Unidas, se quisessem socorrer aos da Companhia; e que sem isso ela não podia sustentar-se no Brasil. (COELHO, 2003: 62).

Os relatos de Duarte Coelho descrevem a resistência portuguesa e espanhola, não chegando na Batalha de Guararapes, que é o grande símbolo da vitória portuguesa e de um primeiro sentimento de pertencimento que será as bases para formação do sentimento patriótico. Ele descreve todos os movimentos até 1639. Depois de 1640 começa a Insurreição Portuguesa, que irá por fim na dominação da coroa espanhola sobre o reino de Portugal e ascenderá a dinastia de Bragança. A guerra contra os holandeses se arrastaria ainda mais tendo chegado ao fim mais de 10 anos depois.

\section{A batalha de Guararapes: o espírito luso-brasileiro}

A batalha de Guararapes ocorreu depois de quase uma década de guerra de guerrilhas das forças portuguesas contra as forças batavas. Esses embates foram criando um sentimento de identidade muito forte criando um laço e uma ideia de expulsar os invasores holandeses. Essa batalha marcou o sentimento luso-brasileiro com a união de forças quilombolas, indígenas e portuguesas.

Os holandeses tentavam penetrar no continente e ter o controle da renda da terra, mas a guerra de guerrilha luso-brasileira não permitia 0 avanço das forças comandadas por Schkoppe, pois apoiadas pelo governadorgeral em Salvador tinham como ser sempre abastecidas. As ações de ataque 
ocorriam nos canaviais que eram queimados para prejudicar a empresa holandesa. Os holandeses enviaram em 1648 o almirante Witte de Wit para comandar a ação de penetração do Brasil holandês, que envolvia ocupar a Bahia e expulsar os portugueses. A grande questão que as autoridades holandesas se fazia era saber "se Nassau fracassara em 1638, como realizá-la no momento que a capital da América portuguesa estava sob proteção da armada portuguesa, o que não fora o caso de dez anos atrás?" (MELLO, 2010: 436). Os holandeses chegam a ocupar a ilha de Itaparica, mas não conseguem o total domínio como reporta MOREAU em "História das últimas lutas", pp 6566.

\begin{abstract}
Schkoppe e seus homens tornaram-se senhores absolutos da ilha e para ali melhor se firmarem construíram um forte, que chamaram de real, á beira da margem, do lado da Bahia, ao abrigo do qual estavam ancorados os seus navios. Alguns destes se conservavam sempre à espreita da saída ou entrada das caravelas na Bahia, não ousando ir procuralas no canal, devido artilharia dos fortes, enquanto outros cruzavam o mar aqui e ali, na esperança de caçar navios inimigos. Os da Bahia, temerosos de vizinhos tão perigosos que os impediam de mostrar-se, não ousavam sair nem vir com tempo claro e sereno, só se aproveitando das estações tempestuosas e cheias de procelas, durante as quais era impossível batalhar no mar. Resolvidos que estavam a expulsar os holandeses da ilha de Itaparica, aí desembarcaram uma noite, aproveitando-se da escuridão, 1500 homens em barcas, patachos e escalares e estes se entrincheiraram na outra extremidade da ilha, de onde os holandeses não conseguiram expulsá-los (apud MELLO, 2010:430-431)
\end{abstract}

Então, a ideia principal era atacar o inimigo impedindo que as forças de holandesas que vinham de Recife chegassem na Bahia e pudessem apoiar a ocupação de Salvador. Essa é conhecida como a Primeira Batalha de Guararapes em abril de $1648^{34}$ (ver esquemas: Anexo 1). E a Segunda Batalha

\footnotetext{
${ }^{34}$ IN: "Dicionário das Batalhas Brasileiras". DONATO (1996): Primeira das duas batalhas travadas nos Montes Guararapes, proximidades do Recife. A situação da guerra naquele momento: luso-brasileiros, aproximadamente 3000 combatentes; holandeses, $5000 \mathrm{com}$ apoio considerável da esquadra. Regressando ao Recife, da llha de Itaparica, onde permanecera praticamente todo ano anterior, o gen. Van Schkoppe decidiu romper o cerco imposto a capital holandesa pelos insurgentes. A 18, com 4.500 dos seus melhores soldados, deixou Recife rumo ao sul. A esse tempo o chefe insurgente Barreto de Menezes, recém-fugido à prisão flamenga, correra a apresentar-se (13.04) no renovado Arraial do Bom Jesus. Assumindo o comando informado da saída de Schkoppe, entendeu chegado o momento de enfrentar 0 dominador em batalha campal. Partiu do Arraial à frente de 2.200 homens divididos em três
} 
de Guararapes em fevereiro de 1649 (ver esquemas Anexo 2 e comentários Anexo 3) fez as forças batavas voltarem para Recife com uma perda que irá colocar de uma vez por todas a inviabilidade do projeto holandês em terras brasileiras.

E ainda nesse contexto foi arquitetado pelos nobres portugueses a retomada de Angola. Acontece que, para tal feito o contingente de forças, em Portugal e em Angola não eram suficientes, se fez necessário juntar as forças de reconquista de Angola uma força expedicionária luso-brasileira para libertar a terra africana do império ultramarino português.

\begin{abstract}
Assim, entendemos que a reconquista de Angola pela frota luso-brasileira comandada por Salvador Correia de Sá, teve uma importância vital para a própria existência de Portugal não só como metrópole, mas também como reino independente no cenário europeu do século XVII. Embora não cabe ao historiador julgar o que teria ocorrido se a história não tivesse se dado de uma maneira, mas de outra, é certo que sem Angola, tal como dizia o Padre Antônio Vieira, não haveria Brasil e, não havendo Brasil, a situação de Portugal ficava bastante enfraquecida diante de Espanha, França, Inglaterra e dos próprios holandeses. (BEIER,2012)
\end{abstract}

terços. Pela tarde de 18 ocupou os Montes Guararapes, escolhendo o desfiladeiro a leste como sítio ideal para o confronto. Ordenou a destruição da ponte do Muribeca e expediu o cap. Bartolomeu Soares da Cunha para, na Barreta, tomar contato e atrair o inimigo. Dispôs a sua tropa: vanguarda, responsabilidade de Vidal de Negreiros, sobre a linha de marcha do adversário, entre o brejo e o monte do norte; na direita, Felipe Camarão, disposto na baixada; no sopé do monte escolhido, Henrique Dias; Fernandes Vieira, com a reserva, ao sul do riacho que desce dos montes entre as elevações central e sul, o esquadrão da cavalaria de Antônio Silva, cobrindo a retaguarda da gente comandada por Henrique Dias. Ao escurecer o exército pode ouvir que Bartolomeu Cunha lutava na Barreta. Pelas oito horas do dia 19, o cap. Cardoso, dos postos avançados, recuou diante do inimigo, canalizado no desfiladeiro 0 principal avanço holandês. A vanguarda, alinhando dois regimentos ordenados pelo cel. Elst, investiu incontinente sobre as posições ocupadas por Vidal de Negreiros. Foi escalando o monte, repelindo Henrique Dias e assestando artilharia na altura que conseguira conquistar. Barreto de Menezes atirou-se contra Elst, acionando a cavalaria e parte da reserva. Socorreu a posição de Henrique Dias e recuperou a elevação, tomando a artilharia dos flamengos. Schkoppe lançou em ajuda de Elst os regimentos de Hauss e Brinke, cujos homens retomaram a artilharia, acometendo mais agudamente o dispositivo de Henrique Dias. Foi o momento grave da batalha. Schkoppe decidiu jogar tudo e com os regimentos Brande e Houtain investiu as formações de Camarão e de Vidal, os quais recuaram para o meio do brejo onde a quase nudez e habilidade dos índios levou a melhor sobre o pesado e incômodo equipamento e inexperiência do inimigo naquele terreno. Barreto, aceitando também ser necessário tentar o possível, enviou o que ainda dispunha da reserva para reforçar Camarão e Vidal entregando a este a condução do ataque. A onda de assalto obteve resultados. $\mathrm{O}$ srg. Afonso Rodrigues apoderou-se do estandarte-insígnia de comando superior holandês. O sucesso do combate corpo-a-corpo no brejo comprometou o flanco adversário. Vendo-se repelido no desfiladeiro e sem saída no brejo onde sofria perdas substantivas, os holandeses iniciaram movimento de retração. Estava ganha a primeira batalha dos Guararapes. 
Libertando Angola, pode Portugal continuar em sua aventura imperial ultramar com um sentimento de proporção telúrica que possibilitou manter esses espaços coloniais ultramarinos seguros por ainda mais tempo. A guerra de guerrilha, combinada com ações vultuosas de campo de batalha, permitiu a Portugal, mesmo em condições militares inferiores, continuar dominando muitas de suas praças perdidas durante o período da União Ibérica e das invasões holandesas. 
Segunda Parte - A Geografia militar no Brasil: por uma busca do autoconhecimento. 


\section{CAPÍTULO 4 - A FORMAÇÃO DO ESTADO NACIONAL, O NASCIMENTO DAS INSTITUIÇÕES MILITARES E A GEOGRAFIA MILITAR NO BRASIL NA AURORA DO "LONGO" SÉCULO XIX.}

\section{Introdução}

Dois eventos do século XVIII marcaram os rumos dos séculos XIX e XX em no que concerne a suas organizações políticas no quadro das Relações Internacionais: a Independência dos Estados Unidos (1776) e a Revolução Francesa (1789). Ambos impulsionaram o desenvolvimento dos Estados Nacionais que irão trazer à luz dos povos e das nações, a possibilidade de participar na organização, administração e na defesa do Estado que será dirigido doravante pelos os ideais e anseios nacionais. $O$ longo século XIX será marcado por uma profunda transformação na organização da política mundial, em especial para os povos americanos. Na sua primeira parte, o processo de descolonização e a decadência dos Impérios Ultramarinos europeus (Portugal, Espanha e França) no continente americano. $\mathrm{Na}$ segunda metade do século XIX, o mundo irá presenciar uma grande evolução na tecnologia militar e da ciência militar. Por sua vez, na América do Sul alguns conflitos internos e de demarcação de fronteira entre as novas nações, tendo como maior deles a Guerra do Paraguai. Por fim, no último período do longo século, a proclamação da República e a Guerra de Canudos, e sua herança maior, "Os Sertões", de Euclides da Cunha que irá usar uma gama de conhecimentos de geografia, antropologia entre outros tantos para explicar o teatro da Guerra de forma científica, se apresentando como a obra prima da Geografia Militar brasileira e da literatura universal, produto deste mesmo longo século XIX.

As expansões napoleônicas e o bloqueio econômico contra Inglaterra imposto por Napoleão iriam empurrar esse processo de formação do Estado Moderno Nacional para terras brasileiras com a chegada da família real e da corte portuguesa fugida das tropas de Napoleão. "O conselho de Estado, reunido na noite de 24.11.1807, aprovava a medida de imediata transferência 
da monarquia para o Brasil" (FROTA, 2000: 222). O caminho escolhido por D. João, o príncipe regente, sempre fora uma questão de Estado e assunto muito debatido pelos dirigentes da corte Portuguesa. A evasão para o Brasil, garantia o Status de Poder da família real de Bragança, assim como sua maior fonte de riqueza, o Brasil. "O refúgio no Brasil apresentava-se lógico, ideia anteriormente esboçada por diversos administradores portugueses, como Marques de Pombal" (Ibidem). Com apoio dos ingleses, todo o aparato estatal foi transferido, tudo necessário à administração pública incluindo seu acervo histórico. "Deixava-se aos invasores uma região sem expressão política" (ibidem). Foi notável a habilidade do príncipe português de se manter neutro durante o ano de 1807, sempre moroso em decidir pelo bloqueio continental e organizando uma saída que garantiria o seu Status de Poder.

\begin{abstract}
Em vão Portugal se esforçava em 1807 por permanecer neutro na grande luta travada entre a França e a Inglaterra; repugnava-Ihe secretamente romper suas relações íntimas com o governo de Londres e continuava a recolher e a abastecer nos seus portos da Europa e da América as esquadras inglesas em ação contra a França e a Espanha, sua aliada. Nessas circunstâncias, o governo exigiu do regente português uma explicação clara e precisa; mas todas as respostas do regente eram evasivas e as suas promessas ilusórias; continuava, com efeito, em segredo, a concluir tratados positivos com a Inglaterra, cujo apoio desejava. A corte de Lisboa embaraçou-se nessas postergações e viu-se de repente ameaçada de uma invasão francesa. $O$ embaixador francês exigiu seus passaportes e retirou-se; o perigo era realmente iminente: de um lado o exército francês nas fronteiras de Portugal, de outro a esquadra do Comodoro Sidney Smith bloqueando rigorosamente a foz do Tejo. Lorde Strangford, embaixador inglês, deixou ao regente a alternativa de entregar a esquadra à Inglaterra ou emprega-la imediatamente no transporte da família de Bragança para o Brasil, a fim de sonega-la à influência do governo francês. Era um momento de decisivo para a monarquia; fazia-se necessário optar entre Portugal invadido e o Brasil intacto. Semelhante situação sugeriria o mesmo meio de salvação ao Ministro Pombal, quando da invasão dos espanhóis, no reino de D. José I. (DEBRET, 1985:354).
\end{abstract}

Dessa forma, nasce a "nação geopolítica" (MARTIN, 2007), de uma ação geopolítica, ou seja, da transferência da capital do reino de Portugal. A transferência da corte trouxe o surgimento de Instituições essenciais para o 
funcionamento do Estado (entre elas toda uma estrutura militar que nos é de interesse analítico), nossa base espacial e uma política externa que deveria ser a resposta da ação da coalizão Franco-espanhola.

Por outro lado, só foi possível para família real se estabelecer em seus domínios, pois já havia um espaço-base bem delimitado, a "base de sua formação territorial no longo século XVI" (ROBERT MORAES, 2000). Segundo FREIXINHO (1994), até o processo de independência do Brasil (1821-22), o espaço-base do que viria a ser o território brasileiro já estava delimitado. Este foi resultado da expansão lusa no período colonial através de seus núcleos básicos: baiano, maranhense, paraense, nordestina e paulista. A chegada da família real marcou um progressivo fator de centralização que trará para 0 País-Continente a seu laço forte de unidade e de um reconhecimento de todos os núcleos básicos, mesmo com diversas resistências, uma identidade com o poder central do Rio de Janeiro. Esse processo de progressiva centralização, ao longo do processo colonial, criou relações rígidas e ao mesmo tempo flexíveis que possibilitaram o reconhecimento mútuo do poder regional e com poder central e a busca da família real de Bragança por estabelecer seu Status de Poder criaram uma integridade territorial mesmo que na prática o poder central não alcançasse os lugares mais longínquos e nos rincões mais esquecidos.

Isso forjou o mais forte elo de unidade política, jurídica e administrativa. Durante esse período, os brasileiros adquiriram o hábito de olhar para o Rio de Janeiro - alguns, com relutância - como sede de um governo central, como de origem efetiva do poder e como fonte de legitimidade de toda a autoridade, em termos políticos, jurídicos, econômicos e administrativos.

Ademais, ao longo da independência, no decorrer de treze anos, coube a um membro da própria Casa de Bragança legitimar, sucessivamente, a transição de um Vice-Reinado para um Reino (D. João VI); de um Reino para um Império Independente (D. Pedro I); e da consolidação de um EstadoNação Uno (D. Pedro II). (FREIXINHO, 1994: 83)

Com o governo de Portugal instalado no Brasil, o príncipe regente criou uma série de ministérios e instituições do Poder. Foi criado o Ministério do Negócio Estrangeiro, a pasta da Marinha e Ultramar e a dos 
Negócios do Reino. Em cinco de abril, o príncipe regente cria a Intendência Geral de Polícia da Corte, algumas repartições são igualmente criadas como: "Conselho de Estado, Mesas de Consciência e Ordens e do Desembargo do Paço, Casa suplicação, Conselho da Fazenda". (FROTA, 2000: 224). A primeira Impressa com tipografia vinda de Londres, primeiros órgãos de impressa. Ainda em 1808, foi criado o Arquivo Real e a Biblioteca real.

Sobre as questões militares foram uma série de medidas realizadas pelo governo português no Brasil como se segue em FROTA (2000: 225-226):

\begin{abstract}
Uma das primeiras medidas constituiu em instalar a Academia Real dos Guarda-marinhas (...). Criou a Academia Real Militar, por portaria de 4 de dezembro de 1808, provisoriamente sediada na Casa do Trem, depois, em 1812, transferida para o edifício inacabado da Sé, no Largo de São Francisco de Paula; seu curso totalizava sete anos letivos (...) ativou o Arsenal Real do Trem, antes chamado de Casa do Trem, e a Casa das Armas, situado no Morro da Conceição.
\end{abstract}

Em 13 de maio de 1808, o Príncipe D. João criou o $1^{\circ}$ Regimento de Cavalaria do Exército, com oito companhias. No mesmo dia, instituiu a Guarda Real do Príncipe ou Archeiros da Guarda Real (...). Em 1809, fundou um corpo de artilharia a cavalo, invenção espanhola. Em 13 de maio desse ano, criou a Divisão Militar da Guarda Real de Polícia da Corte, em tudo semelhante à sua congênere de Lisboa.

A conjuntura da política internacional exigia uma ação do príncipe português, uma contrapartida às perdas territoriais impostas pelas forças de Napoleão. Portugal fora dividido em três regiões e invadido pelas forças invasoras; usando a reciprocidade, o regente atacou a Guiana Francesa e a Cisplatina, como forma de retaliar a França. O fundamento da política de D. João, segundo FROTA (2000:236), residia na estreita aliança com a Inglaterra. "Mal chegara, lançou D. João uma proclamação, a $1^{\circ}$ de maio de 1808 , explicativa da sua vinda para o Brasil, no novo império que viera criar, terminando por declarar guerra à França" (Ibidem).

O território Francês, de acordo com FROTA (2000:236), apresentava um duplo interesse para política joanina: a Guiana era militarmente indefesa e permitiria fixar de uma vez por todas a linha 
demarcatória entre o Amapá e a Guiana, por quase 200 anos a França e Portugal contestavam as fronteiras no Rio Oiapoque, que para os franceses era ora era reivindicada no Cassiporé (ver figura) ou em outros rios da região, como afirma o excerto a seguir, "os franceses ora reivindicavam a fronteira no Araguari, ora no Carapaporis, ora no Cassiporé, Cunani e Calçoene" (MEIRA MATOS, 1980: 43).

Dom João desembarcou em 8 de março no Rio de Janeiro e a 10 de junho de 1808 declarou Guerra aos franceses autorizando os luso-brasileiros fazerem guerra, por terra e mar, o que anulou os tratados anteriores e ordenou a conquista de Caine como represália à França pela invasão de Portugal; para evitar que os franceses mantivessem uma base de apoio na América; para fixar definitivamente no Rio Oiapoque os limites Norte do Brasil, a fim de manter a posse do Rio Amazonas e para buscar suas especiarias. (ROSTY, 2011:44)

Ao Governador Geral do Grão Pará, José Narciso Magalhães de Menezes, coube a missão de organizar a operação para a conquista da Guiana Francesa, "constituiu o núcleo da Força Expedicionária com duas Companhias de Granadeiros duas de Caçadores do $1^{\circ}$ e $3^{\circ}$ Regimentos de Linha (Estremoz) e uma Bateria de Artilharia com três peças de seis polegadas" (ROSTY, 2011:44), essa força composta de 450 homens organizada na cidade de Belém e comandada pelo Tenente-Coronel Manuel Marques D'Elvas Portugal, que recebera mais 350 homens de reforço de D. José Narciso. Os ingleses apoiaram a operação com uma escuna chamada Confiance da esquadra do Almirante Sidney Smith comandada por seu sobrinho Capitão James Lucas Yeo que chegou em Belém no dia 3 de outubro de 1808. A coroa ainda enviou "dois navios de guerra portugueses com 18 canhões cada um, comandados por Luís da Cunha Moreira" (Ibidem, 2011). Nos navios portugueses haviam fuzileiros-navais ao todo a coalizão portuguesa tinha 1200 homens.

Partiram de Belém a 22 de outubro, integrando a esquadra de James Lucas. Em 29 de novembro, os fuzileirosmarinheiros chegaram ao ponto de encontro, Foz do Rio Caiporé, onde a flotilha de Marques os esperava. A Força Expedicionária, agora completa, dobrou o Cabo Orange, indo ancorar na Foz do Oiapoque. Eram, ao todo, 800 soldados e 300 fuzileiros navais, embarcados para 0 Combate. 


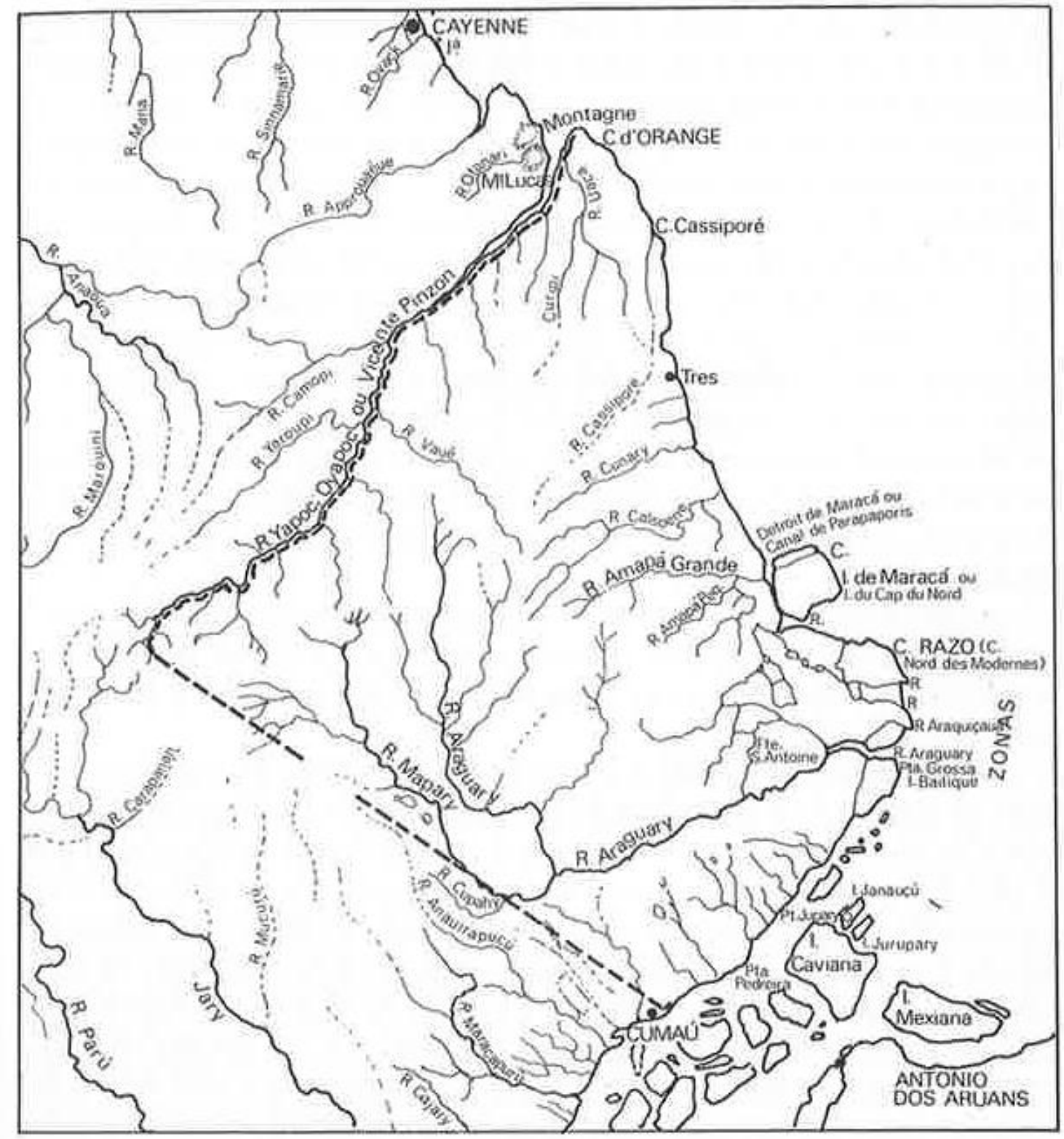

Figura 9 - FONTE: MEIRA MATOS, 1980:47. 
As forças inimigas contavam com um contingente limitado como é descrito a seguir:

Em Caiena, o Comissário do Imperador Napoleão na Guiana, Victor Hugues, contava para defesa, com apenas 511 militares profissionais, 200 milicianos e uma centena de escravos armados. Ao todo, em torno de 900 homens. (FROSTY, 2011:44)

A conquista de Caiene ocorrerá em algumas operações que tiveram pouca resistência por parte dos franceses. São elas: a ocupação da margem direita do Oiapoque ( $1^{\circ}$ a 13 de dezembro), o combate em Aprouague (14 de dezembro de 1808 a 5 de janeiro de 1809) - considerado a primeira ação de combate dos fuzileiros navais do Brasil -, a batalha no Mahury (6 de janeiro a 9 de janeiro de 1809) - considerado o combate mais sangrento da campanha - e a Rendição de Caiene em 14 de janeiro de 1809 que termina com Marques assumindo como governador provisório de Caiene. Do ponto de vista da organização militar, a Conquista de Caiene inaugurou a formação de fuzileiros navais e deu para as forças luso-brasileiras um caráter anfíbio importante. No aspecto geopolítico garantiu no plano internacional as fronteiras do Brasil com a Guiana Francesa no rio Oiapoque e delimitou o território de forma definitiva, embora o Amapá continuasse a ver incursões francesas por seu território.

No Combate em Aprouague ocorreu o batismo de fogo dos Fuzileiros Navais. A campanha em Caiena evidenciou que os componentes da tropa luso-brasileira possuíam um diferencial: a vocação anfíbia. Eram destemidos combatentes que realizaram a primeira operação combinada na Amazônia. (ROSTY, 2011:50)

$\mathrm{Na}$ parte meridional da América do Sul, D. João, o príncipe regente, ocupará a Banda Oriental do Uruguai, chamada de Cisplatina (ver figura). Desta forma, o governo português teria nessa invasão as mesmas prerrogativas da ocupação de Caiene, uma represália à invasão do seu território. "Consistia, na verdade, um único plano com dois desdobramentos". (FROTA, 2000: 237).

Em uma nota (13 de março de 1808), logo após chegar ao Brasil, D. João ofereceu proteção ao Cabildo de Buenos Aires, visto que os cabildos 


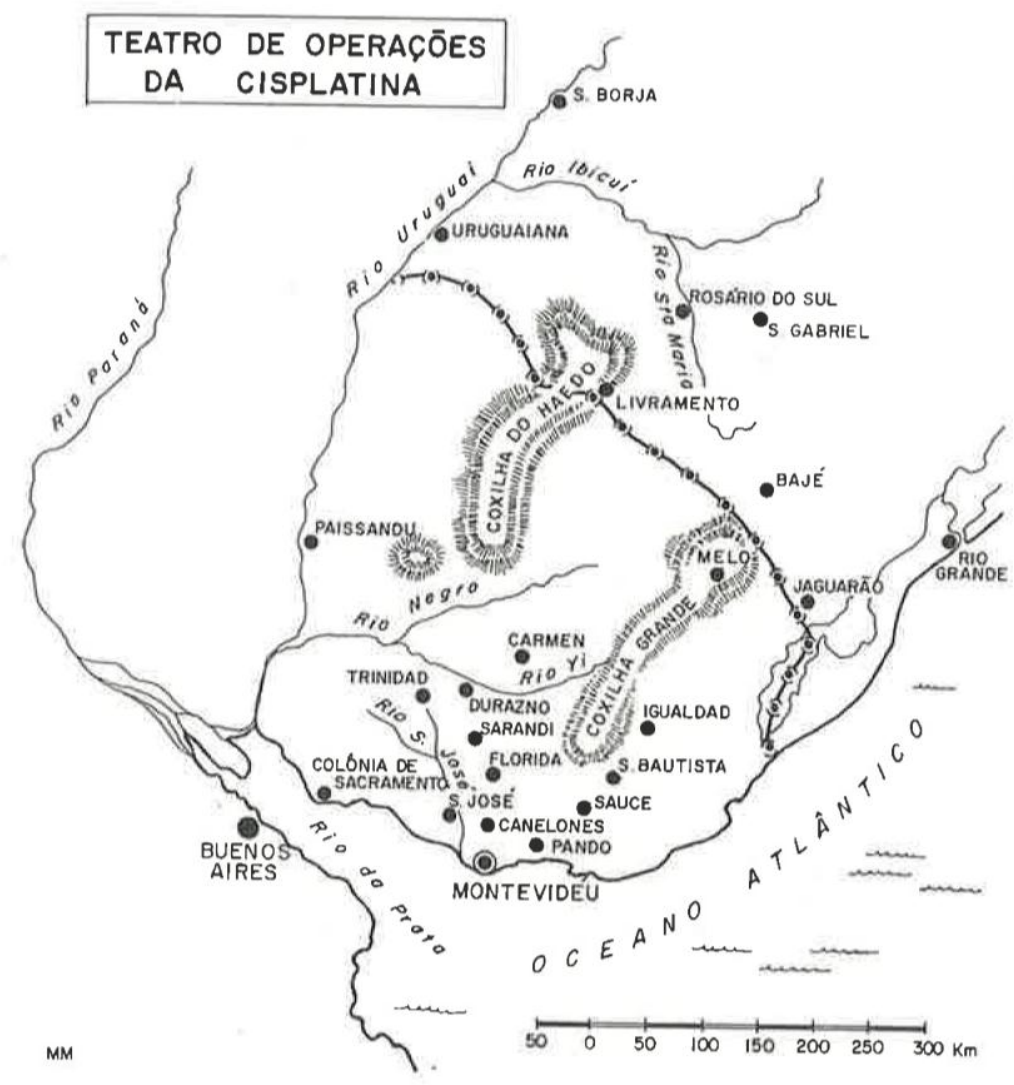

Figura 10 - Fonte: FERREIRA ALVES,1979:51 
hispano-americanos não aceitavam a autoridade do Rei D. José I (1808-1813), que era irmão de Napoleão. "D. João oferecia ao Cabildo de Buenos Aires a sua proteção e ameaçava usar a força para que a mesma fosse aceita" (FROTA, 2000:237). A Infanta Carlota Joaquina, esposa do príncipe regente português, era filha de Carlos IV e irmã de Fernando VII de Espanha, destituídos por Napoleão. Carlota dirigiu um manifesto aos espanhóis da América que dizia garantir o império para ser entregue a seu irmão ou, caso a conjuntura não retrocedesse e os Bourbons não voltassem para o trono espanhol, manteria as terras para sua própria descendência. "D. Carlota Joaquina comprometia-se a organizar novo império para ser entregue a seu irmão Fernando VII ou manteria para sua própria descendência" (ibidem, 2000: 239).

Segundo FROTA (2000:239), a conjuntura para intervenção na região do Uruguai era bem favorável. Buenos Aires pretendia estabelecer sua hegemonia neste território que tinha José Gervásio Artigas, que pretendia organizar uma federação das províncias vizinhas do rio da Prata, que expulsou os espanhóis permitindo os argentinos sitiarem Montevidéu (Ver figura). Em 1811, D. João organizou um exército de Observação que ficou acantonado na capitania de São Pedro do Rio Grande comandado pelo Capitão-General D. Diogo de Souza, auxiliado pelos brigadeiros Manoel Marques de Sousa e Joaquim. D. João tinha como objetivo a Pacificação e não o domínio do território. Dessa forma os luso-brasileiros marcharam em 17 de junho de 1811, invadindo a Banda Oriental com uma força que totalizava quatro mil homens. "Ocuparam Melo em 23 de julho; prosseguiram em direção ao Chui ultrapassando-o. Permaneceram um mês no Forte de Santa Teresa". (ibidem, 2000:239). Quando as forças chegaram em Maldonado acamparam em 12 de outubro (Ver figura). O Vice-rei do Prata e os portenhos firmaram um acordo e seus comandados refluíram para Buenos Aires, enquanto Artigas foi para região das missões. As tropas luso-brasileiras desviaram de Montevideo. "Em 16 de março de 1812, as tropas luso-brasileiras se trasladaram para Paissandu e foram vencendo as reduzidas forças de Artigas em pequenos embates" (ibidem, 2000:239). 
Em agosto de 1811, durante a guerra entre Montevidéu e Buenos Aires, um exército português comandado por Diogo de Sousa penetrou nos territórios ao sul do Rio Grande sob o pretexto de "pacificar" as adjacências da capitania, constantemente ameaçada por incursões de bandoleiros e salteadores. Com isso dava-se início à primeira intervenção armada portuguesa na Região após os movimentos de 1810. (PIMENTA, 2006:103)

A instabilidade política da Banda Oriental do Uruguai continuou, com Artigas fustigando a região e a cidade de Montevidéu dominada pelos castelhanos. De acordo com FROTA (2010:240), os argentinos invadem a região pela segunda vez com uma pequena força naval comandada pelo irlandês William Brown, derrotando a flotilha espanhola em 20 de junho de 1814, obtendo a capitulação de Montevidéu. Entretanto, Artigas expulsa os argentinos em 1815. Com a independência da Argentina, no congresso de Tucumán em julho de 1816, cresce a vontade dos portenhos de incorporar a região ao seu novo país. Na corte do Rio de Janeiro chegou-se a conclusão de quem ocupasse as terras da Banda Oriental do Uruguai e as mantivesse com ímpeto teria o domínio do território, "o Princípe D. João deliberou intervir militarmente" (ibidem, 2000:240), essa ação fora festejada pelos argentinos que queriam ver a eliminação de Artigas que organizava incorporar parte do território argentino no país que pretendia criar, que incluía, além da região "Entrerrios" da Argentina, as Missões em poder de Portugal, desde a Paz de Badajos de 1801.

Organizada uma tropa em Portugal, esta aportava ao Rio de Janeiro em 30 de março de 1816; somavam 4.830 homens sob o comando do Tenente-General Carlos Frederico Lecór. Enquanto isso, o Marquês de Alegrete tomava providências para melhor atuação de seus comandados, sujeitando-se a treinamento intensivo. (FROTA, 2000:240)

O combate aconteceu em duas frentes, uma em nosso próprio território e outra uma coluna que marcharia para o sul, com a intenção de capitular a Borda Oriental do Uruguai. O Marquês de Alegrete ficou com a defesa do Oeste e a Divisão de Voluntários Reais, comandado por Lecór tomou a direção sul (ver figura 11). Atacar, ao mesmo tempo, manter a retaguarda esperando que o inimigo pudesse investir na retaguarda das forças lusobrasileiras (ver figura 11). 


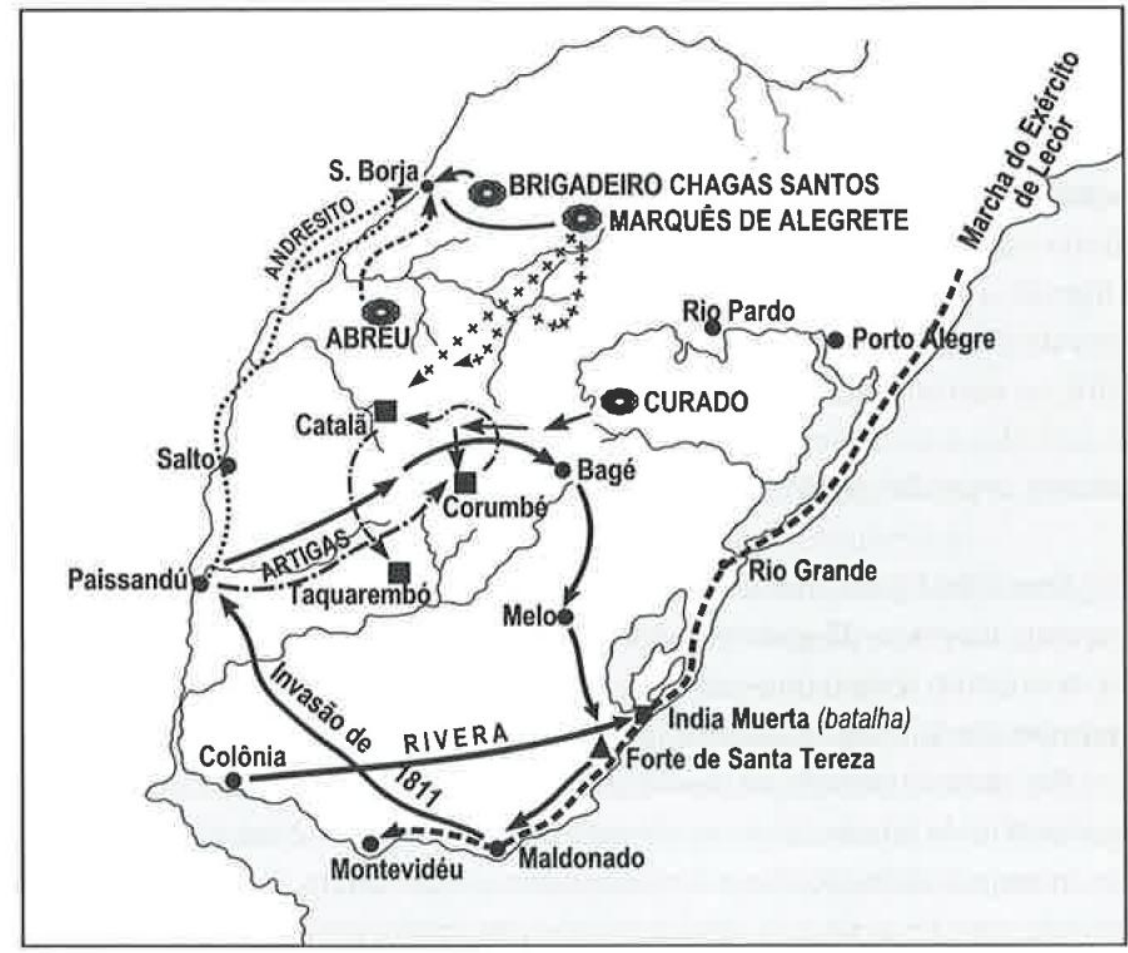

Esquema das invasões ocorridas na Banda Oriental do Uruguai: em $1811 \longrightarrow$ partindo de Bagé

e de $1816 \rightarrow-\cdot$ Frederico Lecór e demais operações no interior.

Figura 11 - Fonte: FROTA, 2000:238. 
O plano português resumia-se em marchar em linha reta até a capital, deixando ao Marquês de Alegrete a defesa do Oeste. Assim, a divisão de Voluntários Reais, comandado de Lecór, embarcou na esquadra liderada pelo Chefe-de-

Divisão Rodrigo José Ferreira Lobo, atingiu Santa Catarina (Vila Desterro) em 26 de junho e, desse local, a pé, tomou a direção sul; a essa força principal, juntaram-se os soldados do Brigadeiro Curado, que teve a missão de proteger a região do rio Santa Maria, evitando que as tropas de Artigas obstaculizassem a investida de Lecór; entre essas tropas de Curado encontravam-se os "barrigas verdes" de Santa Catarina e dragões de São Paulo. (FROTA, 2000:241).

Os combates nevrálgicos para essa guerra foram: de São Borja, Carumbé e os do Litoral, que propiciou a medição de forças de Lecór do lado dos luso-brasileiros e de Frutoso Rivera do lado de André Artigas (filho de José Gervásio). A seguir destaca-se a descrição das batalhas em território nacional:

Combate em Santana e a investida do Coronel José de Abreu na margem direita do Ibirapuitãchico que resultou em notável vitória. André Artigas atacou São Borja, posição defendida pelo Coronel Francisco das Chagas Santos. Informado que Sotelo iria engrossar as forças sitiantes de São Borja, o Coronel José de Abreu movimentou suas forças, atingiu São Borja e caiu de surpresa sobre o inimigo obtendo importante vitória e anulando o plano estratégico de Artigas. Este êxito permitiu que se atacasse Verdun que estacionava em Ibiraocaí; com 150 homens, o Brigadeiro João de Deus Mena Barreto derrotou as forças de Verdun decisivamente (19 e 19 de outubro de 1816).

O combate ocorreu em Carumbé (27 de outubro); o fraco dispositivo de Artigas, apesar de seus 1.600 homens, não suportou o choque de cavalaria e nem a investida de baionetas da infantaria: os remanescentes fugiram perseguidos pelos nossos. Tivemos 26 mortos e 44 feridos; os inimigos, 600 mortos. Observe-se que essas ações militares verificaram-se em território reconhecidamente brasileiro. (FROTA, 2000:241)

Enquanto os combates do interior seguravam Artigas, Lecór avança pelo litoral com seis mil homens. Nas margens do arroio Índia Muerta em 19 de novembro de 1816, depois de quatro horas de confronto, Frutoso Rivera que tinha aproximadamente 1700 homens perde a batalha e foge com 
apenas 100 homens. "Outras pequenas ações ocorreram mas não impediram que Lecór atingisse Maldonado, em janeiro de 1817, e, no dia 20, alcançasse Montividéu" (FROTA, 2000:241). Os portugueses ainda são contra-atacados por André Artigas, que foge e, em seguida, é capturado e levado ao Rio de Janeiro. O desentendimento de José Artigas e Francisco Ramirez desencadeou uma guerra entre ambos que enfraqueceu o esforço de guerra do líder uruguaio que se retira para Paraguai, enquanto Frutoso Rivera mudou de lado e se integrou as forças luso-brasileiras.

Pode, assim, o governo português no Brasil anexar a Banda
Oriental com o nome de Província Cisplatina, em 31 de julho
de 1821 , depois de habilidosa manobra de D. João junto à
Corte de Madri, inutilizando os esforços da diplomacia
espanhola, jogando com a amizade inglesa e o casamento
de seu herdeiro com uma arquiduquesa austríaca. (FROTA,
2000:242)

Outro ponto importante para se notar do ponto de visa da Geografia Militar é a constituição dos povos que no século XIX estão chegando incentivados pela política joanina: italianos, alemães, ingleses, poloneses, austríacos, franceses (principalmente aqueles que tinham divergência com Napoleão. Vieram também entre todos eles uma séria de figuras notáveis que sobre a ótica da razão, do iluminismo, do positivismo irão construir um olhar sobre um mundo bem diferente não só culturalmente, mas naturalmente. É notável a vinda de importantes naturalistas, antropólogos, geólogos, músicos, desenhistas, professores entre outros. Depois da queda de Napoleão, o governo português "procurou uma aproximação diplomática com a França da Restauração, atraindo intelectuais e militares perseguidos" (FROTA, 2000:228). Vieram o desenhista e professor Jean Baptiste Debret, os irmãos Taunay (Nicolau Antoine e Augusto-Marie) pintor e escultor, August-Henri Victorio Grandjean de Montigny escultor, Simon Pradier gravador, François Ovide professor de mecânica, os irmãos Ferrez (Marc e Zeferino) escultores, e o músico e professor, Sigismund Neukomm, completaram a missão francesa.

Alguns ilustres naturalistas estiveram no Brasil durante a estada na monarquia portuguesa no Brasil. Foram eles: o Príncipe Maximilian von Wied-Neuwied que viajou pelo vale do Rio Doce; o mineralogista John Mawe 
que viajou pelas Minas Gerais e escreveu "Travels in the Interior of Brazil, Londres (1812), outros ingleses deixaram sua impressão sobre o Brazil como Henri Koster, Waterton, Alexander Calderaugh e John Luccok, que passou dez anos no Brasil e publicou "Notes on the Rio de Janeiro and Southern Parts of Brazil, Londres (1820) .

Outra grande influencia estrangeira no Brasil foi a estada do Barão Georg Heirinch von Langsdorff, de origem alemã a serviço da russia, acompanhou o naturalista francês Sain-Hilaire, que chegara ao Brasil em 1816 e atraiu o botânico Carl Beyrich e os naturalistas Georg Freyreiss e Frederic Sellow que visitaram os sertões de Minas.

A chegada da Princesa austríaca D. Maria Leopoldina trouxe ao Brasil mais uma missão composta por outros importantes naturalistas e botânicos como: Johann Emmanuel Pohl da Boêmia; os austríacos Johan Von Natterer e o mineralogista Schüch von Trübau; os bávaros Johann Baptist von Spix e Carl Philip von Martius entre outros.

É nesse contexto que surge uma grande análise estrangeira que aborda a geografia do Brasil sob o aspecto da guerra, essa obra "Contribuições para história da Guerra entre o Brasil e Buenos Aires", publicada pela primeira vez em Berlim em 1834, com autor anônimo, aborda a geografia e o seu uso com uma tonalidade científica que não era tão possível antes do século XIX.

\section{Contribuições para a História da Guerra entre o Brasil e Buenos Aires, uma testemunha ocular.}

A análise desta obra requer alguns apontamentos centrais feitos por Aurélio Porto (1975) e um prefácio da publicação de "Contribuições para História da Guerra entre o Brasil e Buenos Aires", da Editora Itatiaia e Edusp. Para PORTO (1975), não há quase nada que indique, realmente, uma informação segura sobre a autoria do livro.

Mesmo na Alemanha, onde foi publicado não teve referências conhecidas, pois, quer as Bibliografias alemãs, quer as grandes Enciclopédias, como a Brokhaus, nada inserem a seu respeito. Começa esse trabalho a ser divulgado e apreciado, como obra mérito, pelos historiadores brasileiros, seguindo a trilha de Handelman que, em sua História do Brasil, transcreve longos trechos do 
livro. Mas, o próprio Alfredo de Carvalho, grande pesquisador e bibliógrafo, e um dos maiores conhecedores da literatura alienígena, não nos fornece, em sua Biblioteca Exótico-Brasileira, notícia alguma esse interessante estudo. (PORTO apud Uma testemunha ocular, 1975: 9).

Ao que tudo indica, a única pista sobre quem de fato escreveu 0 livro (op.cit, 1975) esteja nas "Efemérides" do Barão de Rio Branco, manuscrito original que se encontra no códice do Instituto Histórico e Geográfico Brasileiro, segundo PORTO (op.cit, 1975: 9), atribuiu com dúvidas e ressalvas ao barão de Carl de Leenhof, capitão de um dos corpos estrangeiros. "Como chegou a esse resultado não se pode saber. Seu copioso arquivo, guardado carinhosamente pelo Itamarati, nada nos revela" (PORTO apud op.cit, 1975: 9). Ainda de acordo com PORTO (1975), no manuscrito a outra indicação que adveio de duas correções feitas a punho do próprio Barão de Mauá com o nome Carlos von Fock, tenente do $27^{\circ}$ de Caçadores, que é riscado e substituído nas entrelinhas pelo nome do Barão Carl de Leenhof.

Onde encontrou o Barão de Rio Branco os elementos para essa presunção? Seu arquivo, por enquanto nada nos revelou e, em toda a bibliografia nacional e estrangeira, que conhecemos, referência alguma encontramos para afirmar ou desautorizar a conclusão dessa presumível autoria. Mas Rio Branco é sempre exato. Suas pesquisas, que descem os mínimos detalhes, como se verifica de seu precioso arquivo, constituem precioso acervo de documentação histórica. (PORTO, apud op.cit, 1975: 9)

Sobre Carlos von Fock, tenente do $27^{\circ}$ de Caçadores, segundo Rio Branco, aponta uma referência sobre a existência de von Fock de nacionalidade sueca na Correspondência de Shaeffer. Em 2 de outubro de 1825, em carta "informa o agenciador de mercenários para o Exército que seguia, (...), afim de ser aproveitado na organização dos corpos estrangeiros" (PORTO apud op.cit, 1975:10). Acredita-se que não seja o mercenário sueco pelo nível de informação tratado no livro (op.cit, 1975), o autor do livro não parece ter sido um mercenário e sim um oficial de mérito com acesso a documentos e com um conhecimento ímpar das guerras do sul e da gente que compunha o teatro da guerra.

As pistas do Barão Carl von Leenhof são um pouco mais detalhadas e suas trilhas podem ser seguidas em alguns documentos 
importantes. Segundo PORTO (op.cit, 1975: 10), nada consta sobre o oficial nas Correspondências de Schaeffer (Arquivo do Itamarati) e também na Correspondência do Marquês de Barbacena (Arquivo Nacional). Entretanto, a indicação de C. Schlichthorst em sua obra "Rio de Janeiro como é" (18241826), com tradução portuguesa de Emmy Dodt e Gustavo Barroso, forneceu "elementos magníficos para orientar as nossas pesquisas, seguindo, assim, no Sul, os passos de Leenhof" (PORTO apud op.cit, 1975:10).

\begin{abstract}
Consta desse livro uma "lista de oficiais que, desde a criação do Corpo de Estrangeiros, estiveram em serviço no Exército Imperial Brasileiro e ainda estão", em 1826. Consta dessa lista, por duas vezes, o nome do barão Leenhof. $\mathrm{Na}$ primeira vez, como tenente, faz parte do $2^{\circ}$ Batalhão de Granadeiros de $1^{\text {a }}$ linha, ex $-1^{\circ}$, reorganizado com essa numeração em dezembro de 1824, e criado por dec. De 13 de outubro de 1823, quando da extinção do Regimento de Estrangeiros. Esse $2^{\circ}$ de Granadeiros, sediado no Rio de Janeiro, inicialmente no Mosteiro de São Bento e, mais tarde, em São Cristóvão, deu origem, em 1828, à sublevação de graves consequências tão bem descrita pelo autor de Beitrage ${ }^{35}$. Em 1825 ainda dele faz parte von Leenhof. (PORTO apud op.cit, 1975:10-11)
\end{abstract}

Segundo PORTO (1975), von Leenhof aparece na lista de oficiais do Corpo de Estrangeiros do Exército Imperial até 1825. Na batalha contra os argentinos, fez parte do Corpo de Voluntários que foi transformado na guerra para o Esquadrão de lanceiros, formado, principalmente, por soldados alemães. O Corpo de Voluntário fora criado para arregimentar os colonos alemães e defender a integridade do Brasil. Esta companhia era composta de oficiais estrangeiros e combateram como Esquadrão de Lanceiros na batalha do Rosário descrita pelo provável autor Leenhof.

a essa Companhia foi concebido terem como comandantes
e oficiais unicamente estrangeiros já conhecidos pelos
serviços prestados ao Exército Brasileiro. Teve assim, o
Corpo de Voluntários, como comandante o major Carlos
Frederico Otto Heise (...); ajudante G. Pfeil; capitão da
cavalaria do sul, Luiz von Quast, depois comandante do
Esquadrão de Lanceiros alemães, na batalha do Passo do

${ }^{35}$ PORTO (1975), Explicação: Contribuição para a História da Guerra entre o Brasil e Buenos Aires, tradução do original alemão Beitrage zur Geschicht Zwishchen Brasilien und Buenos Aires. 
Rosário; tenentes barão von Kettler e barão von Leenhof. (PORTO apud op.cit, 1975:11)

A análise do conflito entre as nações do Prata na formação dos Estados Nacionais da América do Sul é rica. Nesta obra podemos encontrar observações sobre o meio e o homem, usos e costumes, inteligência da guerra, intenções da política Imperial e das forças locais conflagrando interesses que se chocavam em determinados momentos, é considerado por muitos analistas da obra como "um dos melhores trabalhos, vertidos por pena estrangeira, sobre o assunto que tentou tantos outros, nessa fase de formação sul-americana em que se entrechocavam interesses múltiplos" (PORTO, apud op.cit, 1975:5).

A batalha do Passo do Rosário, que resultou num choque sangrento e de muita hostilidade e que foi perdida pelo Brasil, na visão de PORTO (1975), foi um passo importante para superar as discórdias ibéricas e construir um espaço de confraternidade capaz de delimitar as fronteiras dos novos países, pelo menos até a Guerra do Paraguai, onde será resolvida a questão territorial da região Entrerrios e rio da Prata.

\footnotetext{
Intervindo, lealmente, no Uruguai, na Argentina e no Paraguai, fixávamos as linhas mestras do sistema continental, dentro do qual, em defesa da ordem, se fundara a nova política (...). Bolivar, San Martin, José Bonifácio haviam traçado, para a América latina, rumos preciosos de confraternidade continental
}

Esse movimento irá marcar uma mudança de visão do Império do Brasil da expansão geográfica para os sedimentos de "uma nova política precursora do pan-americanismo" (PORTO, apud op.cit, 1975: 06-07). Embora, a testemunha ocular que narra os acontecimentos do teatro da guerra sempre julgue as ações e o comportamento dos povos da região como bárbaros e incultos; visão típica do olhar do civilizador europeu existe em suas análises o reconhecimento de algumas manobras feitas, tanto pelos Oficiais da força Imperial, como os das republicanas. A conclusão do autor, digna de grifo de PORTO (1975), é pessimista em relação ao futuro das três nações que estavam nascendo na bacia do Prata.

Se estas lutas, ainda por muito tempo, conturbarão a vida dos três Estados; se disto advirão para eles alicerces sólidos 
de ordem social, ou se a revolução ininterrupta destruirá as bases fracas sobre que assenta a sua incipiente organização, atirando os povos à barbárie primitiva - não nos é dado afirmar, pois, imperscrutáveis os desígnios da Providência, que se antepõe à percepção da sabedoria humana. Se a experiência da História e a da atualidade nos permite uma previsão do futuro, devemos, infelizmente, esperar se realize antes a hipótese que formulamos em último lugar do que a primeira que apontamos (Uma testemunha ocular, 1975:311)

Em Contribuições para História da Guerra entre Brasil e Buenos Aires, a análise envolve a Geografia em diversas escalas, desde um panorama geral sobre a Geografia do Brasil e da bacia do Prata, até a análise do terreno. Deve-se notar que o emprego da Geografia, no entanto, ainda não chega ao nível de uma análise geográfica feita a partir da segunda metade do século XIX; esta terá um detalhe e uma precisão que a testemunha ocular não poderia ter em seu tempo, mas, mesmo assim, é algo muito avançado se compararmos com o que podemos observar no caso da literatura do século XVII e XVIII.

$\mathrm{Na}$ primeira parte do livro, ele se dedica a falar dos acidentes geográficos, como relevo e hidrografia; localização, dados de latitude, posição em relação aos vizinhos, e regional; clima, diversidade dos tipos climáticos; bacias hidrográficas, sua extensão, caudalosidade, navegabilidade e acesso; tipos de vegetação. No aspecto humano, ressalta a diversidade de povos e características culturais dos povos autóctones que adaptados a vida da região tiveram mais vantagens relacionadas ao meio ambiente, que as forças ocupantes, muito distantes da capital e que não tinham o total controle dos aliados locais.

A segunda parte é um breve levantamento histórico da colonização da região, que é muito bem feito, mas que pouco acrescenta no decorrer do trabalho.

A terceira parte é dedicada ao contexto, como o Brasil ocupou a Cisplatina no período de D. João VI no Brasil e a guerra contra Artigas. Existe uma série de referências ao lendário gaúcho, considerado herói nacional uruguaio até os dias atuais. É descrito o tamanho das forças e algumas de suas movimentações. É quando se pode identificar os primeiros traços de uma análise de Geografia Militar. 
A última parte descreve como o Brasil, mesmo com todas as vantagens militares, números, apetrechos, geografia militar, perde para forças republicanas da Argentina e gaúchos obrigando o Brasil a reconhecer a independência do Uruguai e perder de uma vez por todas os seus direitos dinásticos sobre a Banda Oriental do Uruguai. Neste trecho encontramos uma análise da Geografia Militar da batalha de Passos das Rosas a primeira grande batalha entre as novas nações sul-americanas.

A testemunha ocular da Guerra entre Brasil e Argentina considera importante uma análise geral da geografia dos dois países. "Torna-se absolutamente necessário darmos, inicialmente, uma descrição geral destes dois países" (op.cit, 1975:15). O autor acredita ser fundamental a descrição da geografia dos dois países para que o leitor tenha a compreensão da importância do conflito, "abrangendo situação e qualidade de seus produtos, para que se possa formar uma ideia exata da importância desta questão e da causa da guerra por ela provocada" (ibidem); é o tamanho do território e da população, a localização dos dois países em relação ao continente e distribuição de sua população e o sistema produtivo (rebanhos e pastos) os elementos que colocam, em primeiro lugar, a importância e a causa deste conflito. Portanto, nesta obra alemã temos já um estudo, mesmo que ainda diminuto de uma Geografia Militar no Brasil.

As primeiras análises da testemunha sobre a localização indicam posição, e tamanho. No sentido leste-oeste, as demarcações que vão dos Andes ao Atlântico e no sentido norte-sul, da Amazônia à Patagônia. "Estendem-se Brasil e Buenos Aires quase sobre toda a metade da América do Sul, desde o sopé da Cordilheira até o Oceano Atlântico, e do Equador até à Patagônia" (op.cit, 1975:16). Encontramos uma regionalização do Brasil na análise do desconhecido autor, de certo ainda bem simplificada e com poucas informações, entretanto não se pode dizer que não há o uso de algum tipo de conhecimento e de registros geográficos acumulados com o passar do tempo histórico. Esta é a clássica regionalização que coloca o Brasil como uma grande llha cercada pelas duas grandes bacias hidrográficas (Prata e Amazônica) e limitada pelo mar a oeste como foi expressa no seguinte excerto. "Do norte para o sul, o terreno é caracterizado por três partes territoriais 
distintas: o sistema hidrográfico do Amazonas, o planalto central do Brasil, e o talvegue do Rio da Prata". (ibidem).

Existem alguns erros geográficos, como em uma passagem em que o autor diz que não há notícias do vulcanismo no Brasil ou que o rio Uruguai nasce na Serra Geral (sendo que, na verdade, nasce na Serra do Mar), mas tudo justificado pelo contexto e pelo fato de o autor não ser da terra. $\mathrm{O}$ autor até descreve o regime pluvial do rio Amazonas, entretanto a descrição da Bacia do Prata é a que mais nos importa nesta análise.

A explicação dada sobre a formação do Rio da Prata é bem resumida no seu texto, sendo de seu conhecimento que essa Bacia é formada por três grandes sistemas hidrográficos confluentes: do Paraguai, do Paraná e do Uruguai. "De modo geral se tem sempre denominado Rio da Prata a quase todo sistema hidrográfico que compreende uma enorme região em que correm os grandes rios Paraguai, Paraná e Uruguai, tido como seus afluentes" (op.cit, 1975:20). Ele versa sobre a caudalosidade dos rios e sobre os pontos navegáveis na sua jusante, "só tem um tributário navegável: o Paraná-Guaçu". (op.cit, 1975:21). Apresenta algumas dificuldades na navegação no canal próximo da llha Martim Garcia, "junto à parte navegável do Paraná, a feição de um canal até a ilha de Martim Garcia, o qual tem a denominação de Canal do Inferno, pelas dificuldades que apresenta para navegação" (ibidem). O fator estratégico da ilha de Martim Garcia é ressaltado. "Esta ilha tem um grande valor estratégico, pois, fortificada e guarnecida convenientemente, será a chave para os dois rios domina" (ibidem).

Sobre a desembocadura do rio da Prata, que o autor chama de verdadeiro rio da Prata, assim chamada a sua foz, é feita a análise sobre os seus ancoradouros e navegabilidade, assim como a direção dos ventos leitos rochosos, bancos de areia, elementos de ordem natural que dificultavam 0 movimento no teatro de guerra.

As margens do Prata, de um lado, são completamente dissemelhantes: a direita é tão rasa que os navios têm de ficar afastados delas umas três ou quatro léguas, não havendo abrigo de mato ou elevação qualquer contra a violência dos ventos. (...). A margem esquerda, bastante montanhosa, apresenta pequenos morros, como em Maldonado e em Montevidéu. Não é, porém, menos 
perigosa, mercê à formação pedregosa de seu solo, cheio de recifes (...). (testemunha ocular, 1975:22)

Sobre a navegação da margem esquerda é descrita o movimento das marés e os ventos, indicando uma sazonalidade para melhor navegação da desembocadura do Rio da Prata. Descrevendo que a confluência do Rio Paraná e Uruguai se assemelha a um golfo. Assim ele analisa uma série de movimentações nas batalhas navais do conflito em questão.

$\mathrm{Na}$ estação de enchentes dos rios (...), observa-se maior correnteza da margem esquerda. Além disto, a altura das águas é condicionada pela maré alta e baixa, como também pelo regime dos ventos. Com os de sudoeste a maré se eleva a $4 \frac{1}{2}$ pés, e com o sudeste a cerca de 7 pés. (op.cit, 1975: 22).

Ainda na primeira parte uma descrição da navegabilidade das Lagunas dos Patos e Mirim, "são unidas entre si e, além disto, ao mar por um braço muito estreito, o porto de Rio Grande do Sul. Este só é navegável por pequenos navios e brigues" (op.cit, 1975:23). Depois ele faz a descrição do Canal da llha de Santa Catarina analisando sua dificuldade, como se pode observar a seguir. "Os navios menores, que podem atravessar o canal existente entre o mar e a ilha, conseguem aí um porto seguro, mas, os grandes só na saída norte do canal encontram um abrigo exposto ao vento noroeste" (op.cit, 1975:24). Esta parte termina com uma descrição da costa do Brasil do sul ao norte, trazendo alguns elementos geográficos e suas relações com a defesa do território.

$\mathrm{Na}$ terceira parte do livro é discorrido o contexto e a conjuntura em que se encontravam as forças no vórtice de formação dos novos Estados Nacionais que buscavam demarcar seus territórios para estabelecer o seu poder de fato. A Cisplatina era o território contestado e ocupado por tropas Imperiais luso-brasileiras. $O$ rumo do processo de independência criou uma dúvida entre os líderes das forças ocupantes, a questão era: se seguir o Império ou lutar para estabelecer o status de poder na província, ou ser incorporado pela república argentina?

Essa sempre será a grande explicação para derrota brasileira frente a argentina e forças locais, segundo a testemunha ocular, o quadro 
geoestratégico favorecia o Brasil e, mesmo assim, perdeu o seu domínio na banda Oriental do Uruguai. No entanto, durante o período da vinda da família real portuguesa para terras brasileiras as forças imperiais eram melhores dotadas de comando e de técnica, "um corpo de exército português, de 15.000 a 20.000 homens, que poderiam ser utilíssimos pelos conhecimentos táticos e militares adquiridos nas guerras peninsulares" (op.cit, 1975:126) e, tudo isso, associado ao apoio de forças inglesas, fora muito para as forças locais e as parcas forças espanholas.

A divisão portuguesa incumbida de invadir o Estado Oriental e de ocupar Montevidéu foi organizada pelo general Beresford, tomando a denominação de Voluntários Reais do Príncipe, e passando com a morte de D. Maria I e por decreto de 13 de maio de 1816 a intitular-se Divisão de Voluntários Reais del-Rei. Compunham-se inicialmente de um estado-maior, 4 batalhões de caçadores, 2 corpos de cavalaria e 1 artilharia num efetivo total de 4.850 homens e 800 cavalos, sendo elevada mais tarde a 4.929 com serviços auxiliares. Era comandada em chefe pelo tenentegeneral Carlos Frederico Lecor, que contava com o brilhante estado-maior em que constavam o marechal de campo Sebastião Pinto de Araújo Correia, o brigadeiro Bernardo da Silveira Pinto e os coronéis João Carlos de Saldanha, depois Duque de Saldanha, Antonio Feliciano Teles de Castro e Aparício, Francisco de Paulo Azeredo, depois o Conde de Samodões, e muitos outros. As brigadas eram comandadas pelos brigadeiros Jorge de Avilez Zuzarte de Sousa Tavares, depois Conde de Avilez, e Francisco Homem de Magalhães Quevedo Pizarro, além de outros oficiais ilustres que voltaram a Portugal com a Independência; ou ficaram ilustrando seus nomes nos anais da História do Brasil. (PORTO apud op.cit, 1975:126)

É provável que o autor tivesse pouca informação sobre os combates de 1817, mas sua avaliação coloca as forças de Artigas como muito aguerridas no combate, entretanto pouco organizadas, além de não ter a seu favor uma artilharia com navios apoiando e uma infantaria de grande número e bem treinada como era o caso das forças Imperiais luso-brasileiras. Assim, sua avaliação sobre o combate de tomada de Montevidéu, é bem simplificado e não apresenta tantos detalhes, é, por isso, que sua análise da Geografia Militar do teatro da guerra é diminuta, porém, com grande qualidade teórica; estão esboçados os motivos do êxito das forças coalizadas de Portugal-Brasil e Inglaterra. 
Embora seja ressaltada a inteligência de Artigas, como um grande líder guerreiro, a testemunha ocular ressalta que o apoio logístico das forças ocupantes era robusto, enquanto aos gaúchos restava apenas a guerra de guerrilha, que era bem conhecida também dos luso-brasileiros. Assim, as forças coalizadas usavam de métodos ortodoxos e heterodoxos, a guerra real e a pequena guerra. Desta forma, combinando diferentes métodos, Artigas é obrigado a se retirar para região dos charcos.

Na questão logística, o autor afirma:

$\mathrm{Na}$ guerra que se seguiu e da qual existem poucas notícias, os choques das cavalarias ora pendiam favoráveis a uma, ora a outra das forças em luta, e quando, mesmo, a vantagem fosse dos orientais, estes saíam sempre com prejuízo, em homens e munição que não podiam substituir, ao passo que aos portugueses fácil era renovar as perdas. (op.cit, 1975:129)

Os métodos para fazer a guerra e como a coalizão combinou-as para vencer a batalha, é afirmado a seguir:

Os encontros de mais importância, pela superioridade do inimigo, só podiam ser prejudiciais a Artigas. Devido à superioridade dos portugueses e à eficiência de sua cavalaria, integrada nos moldes de guerra da pampa, não era possível ao general oriental estabelecer o cerco, manobra preferida com a qual vencera aos espanhóis e portenhos, pois os portugueses empregavam com perícia os mesmos processos. (op.cit, 1975:129)

Sobre os métodos ortodoxos do uso das forças e suas relações com o teatro da guerra, destacamos:

Iniciado 0 ataque pela cavalaria ligeira, os chefes portugueses faziam convergir ao centro a cavalaria regular, seguida pela infantaria e pela artilharia, evitando ultrapassar a força inimiga, que não tinha cavalaria regular, nem suficientes infantaria e artilharia para enfrentar o choque. (op.cit, 1975)

Com a independência do Brasil, boa parte do aparato mais qualificado do exército não estava mais a serviço do Império. Mesmo assim, o autor incógnito analisa o Brasil com todas as vantagens de guerra que a sua geografia e quantidade forças possibilitavam. Entretanto, considerava as forças argentinas mais bem qualificadas no que diz respeito à arte da guerra. É bem 
verdade que o autor acredita que ambos os lados eram deficientes na arte da guerra, mas o lado do Brasil em especial tinha debilidades e estavam apoiados nas glórias das conquistas passadas e não se atentaram para as questões políticas internas. As forças locais, para o autor, tinham melhor uso tático de suas estratégias eram melhores executadas, embora mais simples do que as forças brasileiras. Os argentinos já possuam um equipamento militar melhor que das forças locais e o uso tático bem modernizado para época e para região; sempre imitando o modelo militar europeu, sobretudo a estrutura das forças napoleônicas, embora nem sempre com o mesmo nível de disciplina, treinamento, entusiasmo, tática e estratégia. "Apesar de que a organização napoleônica deste pequeno exército fosse mal copiada do original, mais se adequava aos componentes dele, do que a de moldes ingleses que servia ao exército português" (op.cit, 1995:170). Essa é uma das grandes críticas do autor desconhecido, pelo menos a mais bem fundamentada, visto que o debate sobre a constituição das raças locais é imbuída de todas as teorias racistas que eram a tônica do pensamento naquele momento e que hoje se sabe não ter nenhum caráter científico.

Nesta análise o autor nota uma mudança no aspecto militar entre Brasil e Argentina em relação ao período colonial.

$\mathrm{Na}$ guerra deflagrada entre o Brasil e a Argentina ambos os povos se batem por interesses políticos e materiais, arregimentado por forças terrestres e marítimas que, nos antigos campos de batalha do sul, isto é, Rio Grande e Cisplatina, além das forças regulares movidas pela tática militar, têm a seu dispor fortes contingentes de guerrilheiros locais, que se contrabalançavam. (op.cit, 1995: 168)

Depois de feito levantamento dos tipos de força que cada um tinha, o incógnito faz a análise dos objetivos geoestratégicos de cada uma das forças considerando a Geografia Militar de cada uma delas no aspecto dos tipos de força e da relação operação do teatro de guerra.

Como o Brasil não tivesse forças suficiente de desembarque para ocupar as cercanias de Buenos Aires, e daí ataca-la, deveria esse objetivo caber as forças terrestres, sendo, para este fim indispensável a ocupação da Cisplatina, como passo inicial para as suas operações de guerra. Aos argentinos, que não tinham elementos para guerra naval, era essencial, como objetivo tático, invadir e levar a guerra 
às Províncias do Rio Grande e Santa Catarina. Daí para o Rio de Janeiro não era possível o avanço não só pelas dificuldades de transpor regiões montanhosas, como pela falta absoluta de estradas de penetração. (op.cit, 1995: 181182)

Sobre a estratégia do Brasil, o autor afirma que o mar seria a chave para o Brasil vencer a guerra. Dominando os mares e os principais portos as forças imperiais empurrariam os argentinos para o interior se mantendo na Banda Oriental. Enquanto os argentinos deveriam contornar os exércitos brasileiros isolá-los do apoio das forças marítimas e empurrá-los para o Rio Grande.

Assim o objetivo estratégico do Brasil deveria ser ladear o exército inimigo pelo seu flanco direito, expulsando-o da sua base, pois teria vantagem, no caso de um insucesso, de retirar-se para as fortificações marítimas de Montevidéu e Colônia, ao passo que o objetivo do exército argentino deveria consistir em contornar pelo flanco esquerdo, obrigando-o a recuar do litoral para o hinterland. (op.cit., 1975: 182-183)

Observa-se em sua análise um pequeno resumo comparando as forças e a vantagem estratégica do Brasil em relação à Argentina. O autor conclui que o Brasil desperdiçou a chance de ter mais vantagens em relação a sua Geografia Militar do que a Argentina que ainda não era dotada de uma força naval capaz de ameaçar o centro administrativo do Império do Brasil.

\begin{abstract}
A Argentina contava quando muito com 15.000 homens e o Brasil com 25.000, tendo para cada campo de ação as Províncias do Rio Grande e Cisplatina, com uma área de 10 a 15 mil milhas, mais ou menos, com cuja comparação se deduz que não poderiam chegar a uma decisão definitiva sem um movimento popular, uma vez que ambas as potências não se tratassem de um acordo. Tinha, porém o Brasil maiores possibilidades de conquistar Buenos Aires, do que a Argentina o Rio de Janeiro, não obstante serem as condições estratégica aquela pelo fato de ser circundada pelo mar, pelo Prata e pelo Uruguai. (op.cit, 1975:182)
\end{abstract}

Tinha o Brasil a vantagem de já estar, mais ou menos preparado para guerra, com o levante da Banda Oriental contra o qual tivera de aparelhar forças, e pelo fato de depender dele a decisão que deveria ser tomada pelas exigências da Argentina, podendo, por conseguinte, antecipar-se aquela quanto ao rompimento da guerra, aproveitando, também, o tempo que perdia pelo 
afastamento em que estava do teatro das operação. (op.cit, 1975:184)

Outro ponto apresentado pela testemunha é a questão da cavalaria, uma força de extrema importância para o teatro da guerra, onde as coxilhas e vales dominam a paisagem. Para esse cenário, a cavalaria tem uma função ainda mais importante: os horizontes amplos favorecem esse tipo de força, "não obstante o número considerável de tropas em ação tem como principal elemento a cavalaria, só intervindo a infantaria e a artilharia como elemento de socorro" (op.cit, 1975:183).

Assim, os campos de pastagens tornavam-se um dos pontos mais nevrálgicos da estratégia da guerra, aqueles que dominassem as melhores pastagens apresentariam uma cavalaria mais disposta e resistente as longas jornadas. Uma cavalaria rápida, resistente e apoiada por uma artilharia de apoio poderia ser decisiva na guerra. $O$ fator da pastagem representa para a Geografia Militar a logística da operação de guerra, assim como não adianta ter apenas as armas, é necessário ter as munições adequadas; não se pode ter cavalaria na guerra, sem acesso as pastagens. Para tal feito era necessário 0 uso dos rios como elemento de comunicação, visto que como aponta a testemunha autoral, não havia praticamente estradas que ligassem o interior das terras do interior.

A conservação e manutenção das grandes cavalhadas e tropas de gado que se tornavam imprescindíveis ao transporte e subsistência do exército exigiam cuidado especial em relação aos bons campos de pastagens e água, e como só eram estes encontrados nas margens dos rios, de onde também se tirava a lenha necessária para os acampamentos, substituíam eles as estradas de comunicação que faltavam completamente no interior. Assim, era elemento estratégico indispensável tanto para um como para outro exército expulsar o inimigo dos campos apropriados para acampamento, ou antecipá-lo em sua ocupação. Isto impunha às tropas a direção exata para ocupar os vales principais como objetivo inicial. Os brasileiros dirigiam as suas operações na direção do vale do Rio Negro, mais ou menos na direção do curso de seus rios, conjugando assim seus fins estratégicos pelo apoio de fortificações fluviais com 0 essencial de remonta e abastecimento. Os argentinos procuravam, por sua vez, privar o inimigo daqueles recursos, ocupando o vale do Ibicuí e obrigando-o a recuar para o vale da Lagoa dos Patos, mais alto e menos provido de pastagens. Esse 
objetivo não correspondia, porém, aos dois fins essenciais que o inimigo tinha em vista, e teria sido mais fácil a tomada do vale do lbicuí, pois poderia ser atacado ao mesmo tempo pela frente e pelos flancos. (op.cit, 1975: 183)

Nesta análise percebemos a essência do quem vem a ser o termo Geografia Militar. É perceptível a ideia que o fenômeno da guerra desde os primórdios da humanidade levou as sociedades humanas a sistematizarem 0 espaço de tal modo que a origem do estudo de geografia acontece da necessidade de conhecermos o espaço para sobrevivência de sua própria origem. Desta forma, existe uma demanda que é o próprio estudo da Geografia Militar, pois na análise do teatro de operações da guerra surge a necessidade de sistematizar o espaço e classificá-lo de acordo com sua importância e funcionalidade.

Estar pronto para se defender é algo que o Brasil terá como lição e, mesmo assim, não resolverá o problema de estrutura de transportes e de acesso as áreas mais longínquas. Ainda hoje, em pleno século XXI, não resolvemos esse problema em boa parte de nossas fronteiras, principalmente a região amazônica. Toda a vantagem, número, forças, tática, espaço eram maiores para o Brasil do que para Argentina, entretanto, o quesito distância era mais favorável aos argentinos, visto que o coração do comando brasileiro se encontrava no Rio de Janeiro. Por isso, se fez mais do que necessário ao Brasil, preparar o território para defender a Cisplatina, coisa que não fez e que Ihe custou a perda de um território que lhe dava uma posição de destaque no rio da Prata (ver figura).

Sobre a questão logística da operação de guerras das forças do Império é que recaem as principais críticas do autor desconhecido, o excerto a seguir é bem claro nesse aspecto.

Após marchas penosíssimas, à frente de um corpo de 1.500 a 2.000 homens, postou-se na margem esquerda do Ibicuí, perto de Santana, e contariam uns mil homens, cobriu uma linha de mil milhas quadradas, expondo a linha de operações de mais ou menos 60 a 80 milhas, que se estendia do Rio Grande, que só contava com as pequenas forças de milícias. (...). Mas, em vez disso, o comprimento da linha de operações tornou-se um suplício tão terrível, como poderia ter sido o inimigo, e isto pela dificuldade de transporte e pela má vontade do presidente. 


\section{OPERAÇŌES DE 1827}

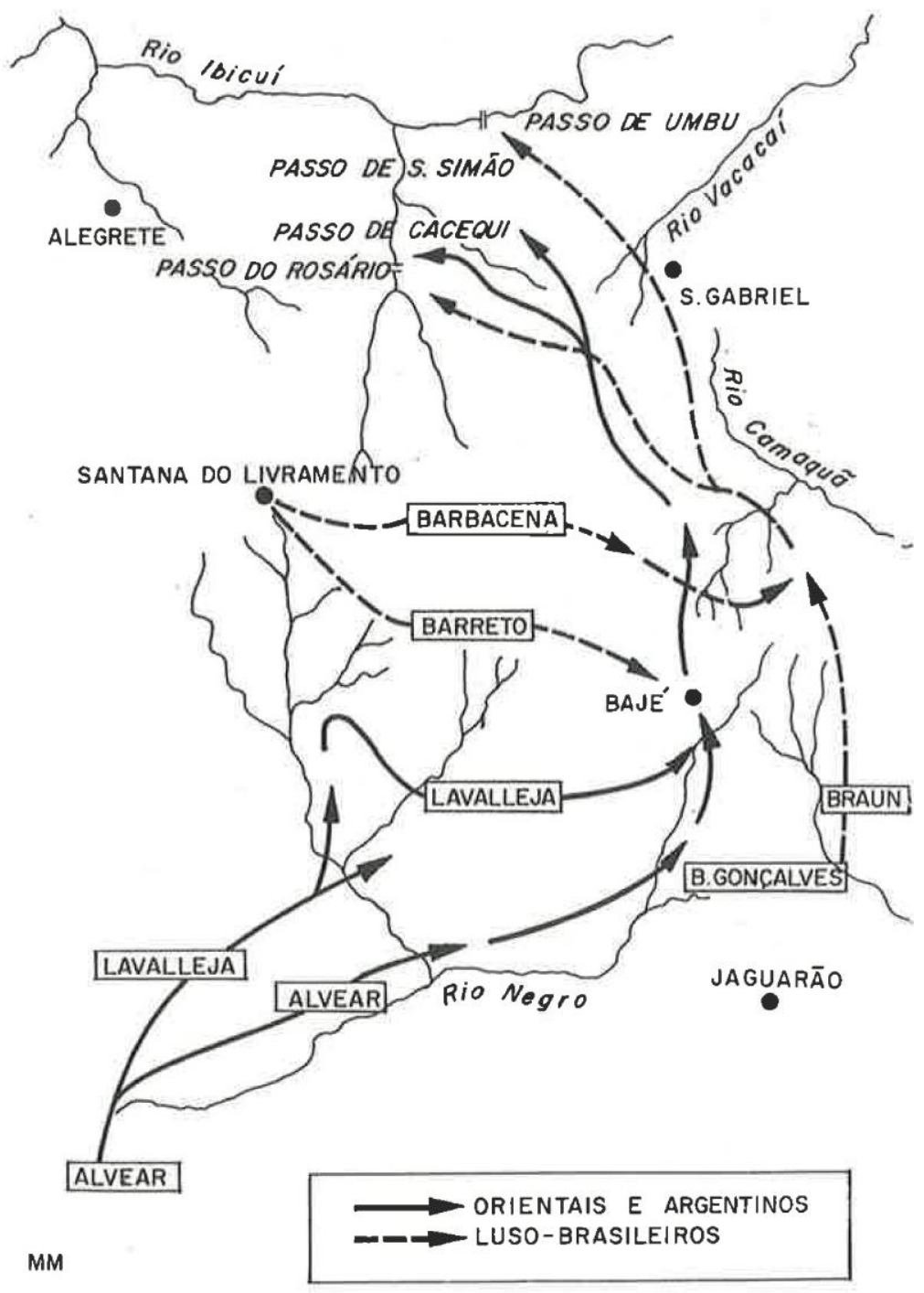

Figura 12 - Fonte: FERREIRA ALVES, 1979: 55. 
Em todo vasto campo de operações, como acima afirmamos, não se encontram, salvo nas lagoas Mirim, dos Patos e rios de maior monta, meios de navegação ou comunicações de outra espécie que poderiam ser aproveitados pelo corpo. A estrada real, pois outra qualquer não existia, pouco frequentada, mal se distinguia, sendo, mesmo intransitável durante a estação chuvosa. Nas viagens e comunicações comuns serviam-se de cavalos e raramente de bestas muares, para viagens maiores, por exemplo, de famílias com mudanças e de transportes de mercadorias. (op.cit, 1975: 185).

Sobre a guerra naval, um aspecto especial das guerras entre Brasil e Buenos Aires, a testemunha assinala bem a estratégia de ambas as forças, em relação a estratégia brasileira, afirma: "começou-se a pensar no bloqueio do Prata, e no sítio de Buenos Aires, com que se evitaria o deslocamento de tropas inimigas para a Cisplatina" (op.cit,1975:187). Os argentinos com uma estratégia de corso hostilizavam os navios brasileiros, "o inimigo conseguira com cartas de corso armar pequenos navios que, pondo-se em atividade mar afora" (ibidem). O comando da esquadra argentina fora dado ao Almirante Brown que era exímio na arte naval e conseguiu grandes feitos com as forças que dispunha.

O desconhecido autor descreve a batalha naval entre o Almirante Norton, Marinha de Guerra do Brasil e o Almirante Brown, entretanto ele realiza um julgamento tendencioso sobre a vitória do comandante brasileiro e a narração do Barão de Rio Branco, em suas Efemérides, narra esta batalha com mais precisão, como segue o trecho retirado da nota de PORTO (op.cit, 1975:189).

Avistando-se navios suspeitos, a fragata Niterói (comandante Norton) e quatro pequenas escunas preparamse para sair-lhes ao encontro. Pouco depois, às 12 1/2 , a fragata 25 de Maio, que estava mais perto e trazia bandeira francesa, arvorou a argentina e o pavilhão do almirante Brown. A Niterói partiu acompanhada das escunas e a 25 de Maio velejou em retirada, navegando à bolina com amuras a bombordo. O vento soprava de leste. Norton soltou todo pano, e as escunas não puderam acompanhar-lhe o andar. Às 3, estando à distância de tiro de peça, a Niterói começou fogo. Às 3 e 10 minutos, o brigue República, que vinha de sudoeste, passou pela proa dos combatentes, disparando uma banda à Niterói e virou de bordo nas águas da 25 de 
Maio. Os dois navios argentinos conservaram-se sempre pelo través de barlavento da Niterói a meia distância de tiro. Às 6 arribaram pretendendo passar pela proa da fragata brasileira; ela, porém, arribou ao mesmo tempo, e largou toda a sua banda, com que forçaram imediatamente os contrários e fizeram força de vela. A Niterói somente suspendeu caça, quando de todo perdeu de vista os dois navios.

A testemunha ocular realiza uma série de questões e algumas outras que envolvem outros personagens desta guerra, como Bento Gonçalves e suas táticas de cavalaria, Marechal Barbacena, que fora criticado pelo autor por ser covarde e retirar as tropas do front da Banda Oriental para o Rio Grande. Entretanto, discordando do incógnito autor, o comentarista da obra PORTO (1975) analisa a retirada estratégica de Barbacena como heroica e bem organizada o que propiciou juntar as forças para a defesa do Rio Grande; entre outras importantes ações e figuras desta breve guerra. Mas, deste pequeno espectro podemos notar que existe uma grande evolução do conhecimento geográfico e da análise da funcionalidade do espaço para construção de um teatro de operações de guerra que é um dos grandes fundamentos da própria Geografia Militar.

A retirada foi feita em relativa ordem, sem perseguição do inimigo. Rio Branco reproduz informações preciosas de testemunhas do feito. O general Mallet disse: "O inimigo apesar de ter quase o dobro das nossas forças, não nos levou para fora do campo de batalha, senão porque nos faltaram munições". OO general Elisiário Brito: "Marchou então o exército com a direita, já reduzido a cerca de 4.700 praças, segundo minha lembrança, repelindo atiradores e cargas de cavalaria, com verdadeira disciplina, sangue-frio não vulgar e valor, poupando munições, não dando tiro sem emprego; e porque os cavalos e parelhas e mesmo a tropa careciam de algum repouso, fez alto; freios aos cavalos e muares para pastarem sobre os cabrestos, e, passadas mais de duas horas, continuou a marcha deixando o inimigo mal que anoiteceu, de acompanhar o exército imperial". O Depoimento de Seweloh completa a informação: "Esta retirada, diz, foi executada à custa de muitos esforços, na maior ordem, mostrando os soldados grande serenidade e sangue-frio como eu nunca esperava ver no Brasil; e se o exército de Buenos Aires era muito superior em patriotismo, tática, organização e força numérica, nós não nos mostramos inferiores na brilhante disposição da nossa retirada, para o que muito concorreu a calma e inexcedível 
coragem do general em chefe. (PORTO, apud, op.cit, 1975:235)

O século XIX foi marcado pelo desenvolvimento intenso do conhecimento geográfico. Era imprescindível para o Império e mais tarde para a República desenvolver o conhecimento técnico do vasto e pouco conhecido território brasileiro. Depois de passadas quase quatro décadas das guerras com a Argentina, o Brasil irá enfrentar mais uma vez suas deficiências estruturais de um território com dimensões continentais, a Guerra do Paraguai (1864-1870). Entretanto, ao mesmo tempo, irá aumentar ainda mais o conhecimento geográfico e o saber geográfico a tal ponto que iremos produzir cartografia na guerra do Paraguai. E mais tarde, o Marechal Rondon irá abrir os caminhos para nos conectar com as distantes paisagens do domínio Amazônico. O desenvolvimento do conhecimento geográfico foi enorme, a ponto de termos na abertura do século $X X$ a produção de os Sertões de Euclides da Cunha.

Infelizmente, não será possível incluir as inúmeras referências de Geografia Militar levantadas pelo estudo para construção da tese, como as Farroupilhas e outras insurreições do primeiro reinado. Entretanto, todos esses levantamentos que não foram utilizados no presente trabalho, serão bases para futuros trabalhos neste vasto campo que ainda requer mais trabalhos e estudos. Neste ponto do nosso estudo, o recorte será pautado dentro do espectro das guerras internacionais, mas é nobre que se reconheça que um trabalho nunca pode ter a pretensão de dar conta de todo um campo e sim de abrir possibilidades para futuras pesquisas. 


\section{CAPÍTULO 5- GUERRA DO PARAGUAI, GEOGRAFIA MILITAR E NACIONALISMO: DEFESA, CARTOGRAFIA E LOGÍSTICA.}

\section{Introdução}

Em meados do longo século XIX, quando se dará o maior conflito já vivido na América Meridional, surgirá a necessidade, dos novos Estados da Bacia do Prata, conhecerem tecnicamente o território e, ao mesmo tempo, que registram seus espaços realizando os primeiros serviços sistemáticos de cartografia, usando balões, e técnicas modernas de cartografia, ver nascer 0 espírito do nacionalismo e da identidade daqueles povos.

É unanime entre os historiadores e cronistas da Guerra do Paraguai (1864-1870) que este conflito foi o mais sangrento do continente e envolveu quatro países da Bacia do Prata (Brasil, Argentina, Uruguai e Paraguai). Sobre as forças envolvidas no conflito, PAULA CIDADE (1959: 178), afirma que o maior peso da guerra recaiu sobre o Brasil, que arcou com as maiores despesas e forneceu os maiores efetivos, inclusive a mais poderosa esquadra da América do Sul. A República da Argentina, embora tenha representado menos de um quarto das forças brasileiras, tinha um papel geoestratégico central, pois sua situação geográfica dava acesso ao teatro de operações da guerra, colocando em suas mãos a foz do Rio Paraguai, por onde passavam as linhas de operações brasileiras, sem a entrada da Argentina o Paraguai teria acesso livre ao Mato Grosso. Por isso, o Brasil realiza um acordo com a Argentina, onde as intenções do império não seriam de expansão territorial e, sim, de preservação das fronteiras e do equilíbrio do poder. As forças do Uruguai não tiveram grande representatividade numérica no conflito, mas sua posição geopolítica garantiria a retaguarda necessária para proteção do Rio Grande do Sul.

A guerra abarcou quase metade do continente da América do Sul, entretanto o principal teatro de operações de guerra (ver figura 13) ocorreu no vale do Rio Paraguai, onde se encontravam os fortes de Curupati, Curuzu, Tuiuti e 


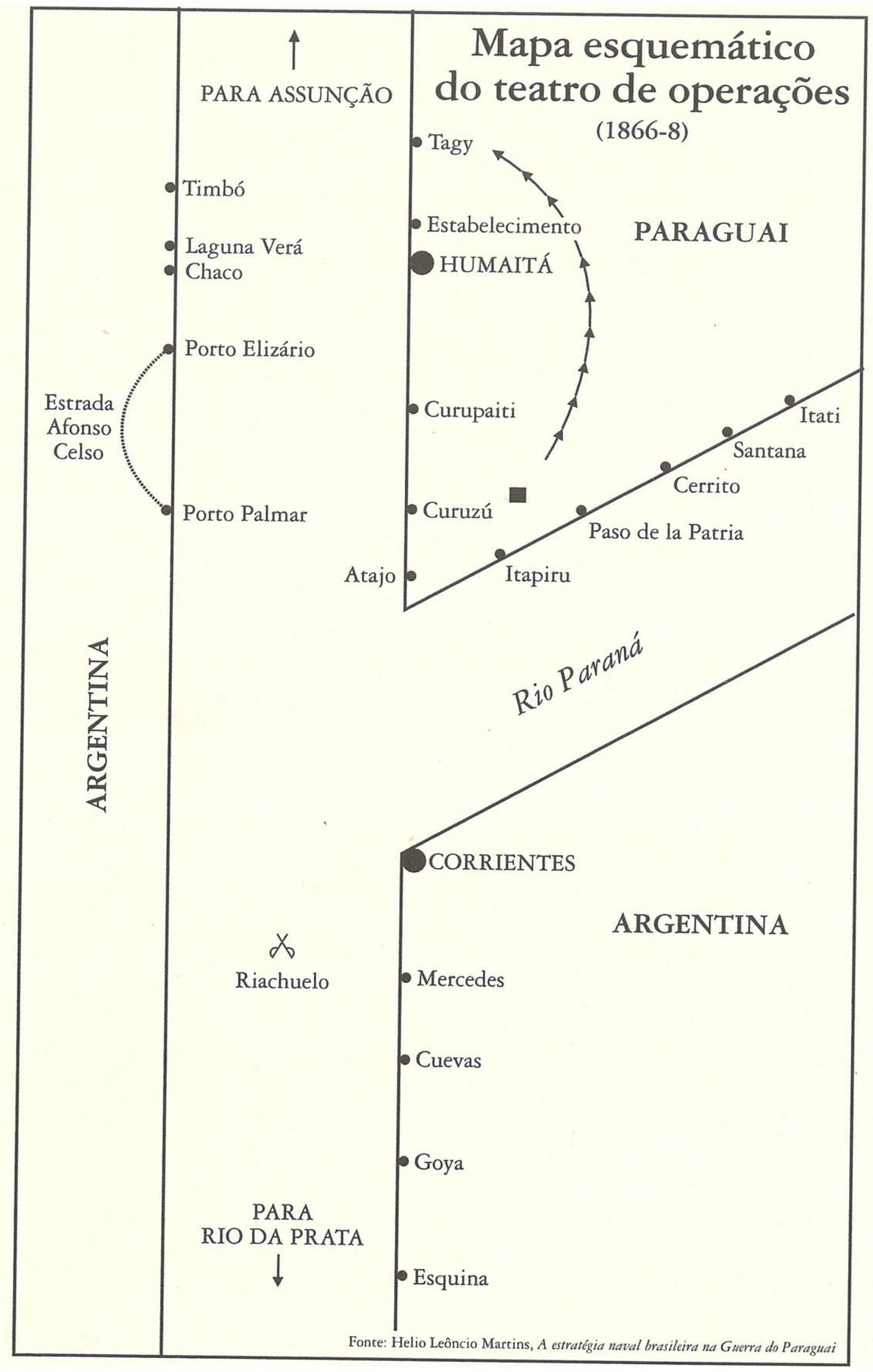

Figura 13- apud DORATIOTO, 2002:190. 
Humaitá. Os teatros secundários são representados pela província argentina de Corrientes e as províncias brasileiras do Rio Grande do Sul e Mato Grosso; a fase final da luta se dará nas Cordilheiras que representa o cerco a Solano e participa como um teatro secundário das operações. FRAGOSO (2009), em seu clássico trabalho "História da Guerra entre a Tríplice Aliança e o Paraguai" dedica dois volumes de seu grande compêndio sobre a Guerra do Paraguai para falar das operações de Guerra que reflete o plano de guerra do então Marquês de Caxias (ver figura 14); sobre deste compêndio, WEHLING (2009) ${ }^{36}$ afirma:

\begin{abstract}
A própria estrutura da obra revela a interpretação militar da guerra. Dos cinco volumes, dois, o terceiro e o quarto, tratam daquilo que considerava o cerne do conflito; a conquista ou neutralização da fortaleza de Humaitá e a conquista de Assunção, isto é, o domínio da principal força militar do adversário e seu cérebro político e estratégico. . Os volumes iniciais, referidos a Mato Grosso e às operações na Argentina e no Rio Grande do Sul, são o introito para a ação principal. O último volume apenas o apêndice que trata do rescaldo da guerra, em que ainda sobra espaço para síntese sobre a história do Brasil oitocentista.
\end{abstract}

Tasso Fragoso baseou-se, para esse encaminhamento, não em uma percepção externa no conflito, mas no estudo dos planos de operações de guerra, que sempre apontavam como objetivo Humaitá e Assunção. Aliás, chamou atenção para o fato de que tais planos fluíram de um protótipo, o plano de operações apresentado pelo Marquês de Caxias em 25 de janeiro de 1865, do qual nem este nem os demais comandantes se afastaram.

A primeira fase do conflito caracteriza-se pela ofensiva paraguaia, "que se irradiaram do centro propulsor de Assunção em duas direções opostas, com objetivos militares e políticos largamente separados entre si" (PAULA CIDADE, 1959: 179). A fase decisiva é marcada pela defensiva estratégica paraguaia e o cerco das forças de coalizadas. A precariedade dos meios de transporte terrestres, no teatro principal das operações, exigia o uso combinado das forças navais e terrestres e "o seu funcionamento é assegurado pela esmagadora superioridade naval brasileira" (ibidem). A batalha que irá mudar de forma decisiva este confronto é uma batalha naval, a batalha de Riachuelo

\footnotetext{
${ }^{36}$ FRAGOSO (2009), In: Prefácio de "História da Guerra entre a Tríplice Aliança e o Paraguai", Rio de Janeiro, Bibliex.
} 


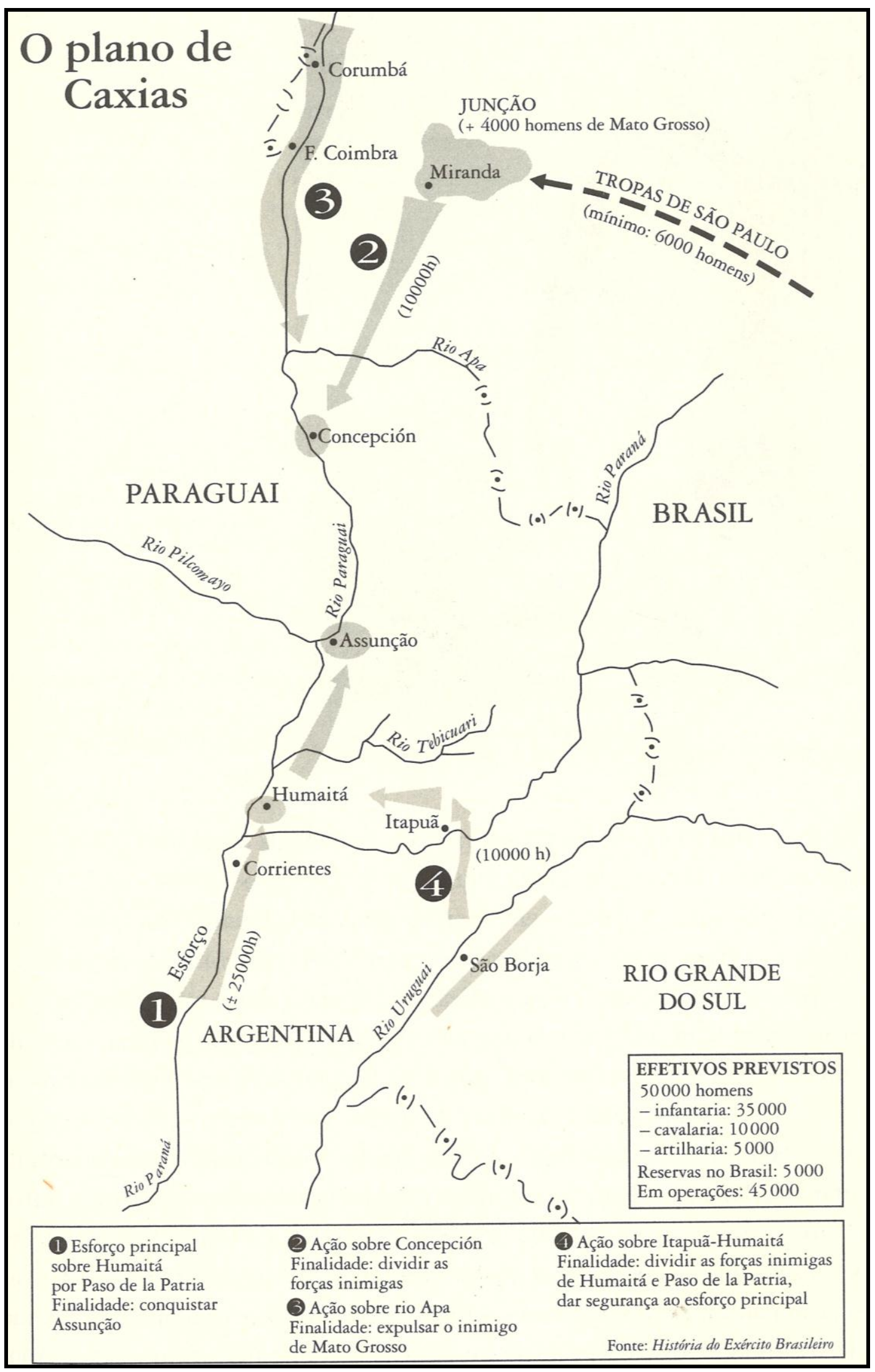

Figura 14- apud DORATIOTO, 2002: 115. 
(1865), que praticamente minguou as forças navais de Solano Lopez e obrigou a força Paraguai a se entrincheirar em sua fortaleza maior (ver figura 15), Humaitá; certamente, que essa ação prolongou mais a guerra e transformou a Bacia do Prata num verdadeiro mar de sangue. Sobre as operações importantes e decisivas da guerra destaca PAULA CIDADE (1959:179):

Devem ser consideradas obras primas de operativa o
desembarque aliado em território paraguaio, a marcha de
flanco que levou os aliados a contornar a forte posição de
Humaitá e as operações de dezembro de 1869, que
constituem manobra estratégica de grande envergadura e
de sabor napoleônico, concebida e dirigida pelo Marquês de
Caxias, que nesse ano fechou com chave de ouro a sua
carreira militar, apoderando-se das linhas de comunicação
do inimigo, obrigando-o a bater-se três vezes seguidas em
batalhas de frente invertida.

Do final da Guerra do Paraguai até o final dos anos de 1950, a biografia sobre o conflito reunia uma vasta literatura sobre o conflito, de certo ainda com muitos problemas de fontes e números que são muito discrepantes com a realidade. Até a década de 1950 o compendio de literatura feito por PAULA CIDADE (1959) aponta algumas obras como as mais importantes até aquele momento. A obra do inglês George Thompson, "A guerra do Paraguai" $(1869)^{37}$, "A guerra da Tríplice Aliança contra o Governo do Paraguai" de L. Schneider (1872), "A história da Guerra do Paraguai" de Teodoro Fix (1870), "Guerra do Paraguai" de A. de Sena Madureira (1870), "História da Guerra do Paraguai" de Max von Versen, "O Atlas da Guerra do Paraguai de Emílio Jourdan (1871), "A Retirada de Laguna" de Visconde de Taunay (1871), "História da Guerra do Paraguai" de José Bernardino Bormann (1897) - alguns dos autores que estiveram direta ou indiretamente estiveram mais próximos do conflito - "História da Guerra entre a Tríplice Aliança e o Paraguai" de Tasso Fragoso (1934).

Até a década de 1950 os textos indicavam algumas teses sobre quem teria começado a guerra, a questão do desenvolvimento econômico do Paraguai e o envolvimento da Inglaterra e as operações de guerra que levaram o Paraguai a uma situação demográfica de decréscimo, foram os temas mais

\footnotetext{
${ }^{37}$ La Guerra del Paraguai, Buenos Aires, 1869.
} 


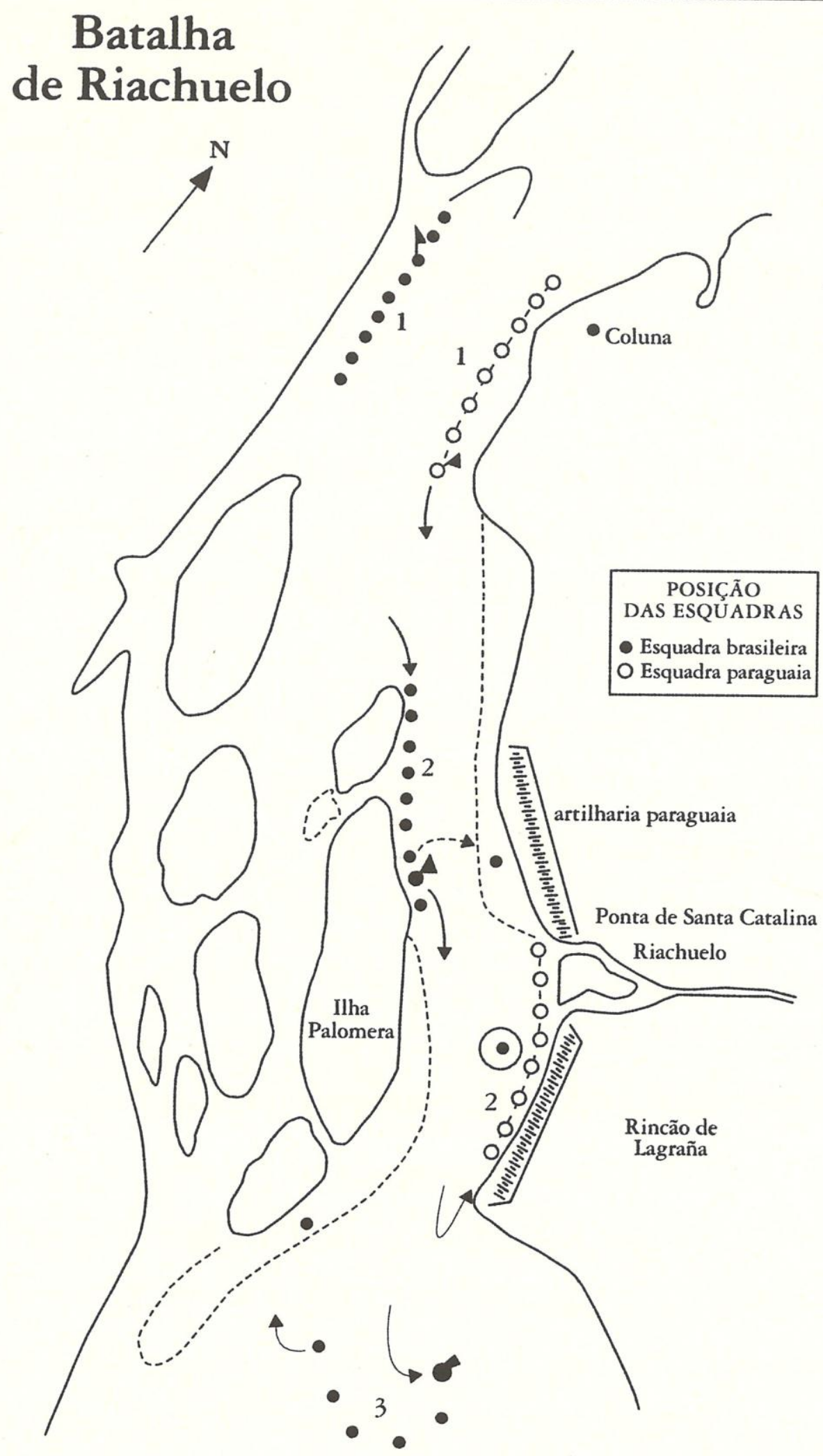

Fonte: Armando de Senna Bittencourt, Visitando Riachuelo e revendo controvérsias

Figura 15 - DORATIOTO 2002: 143. 
centrais dos debates das obras citadas e por muito tempo foram as únicas fontes com as quais poderíamos contar sobre o conflito. A primeira grande controvérsia fora sobre a condição econômica, social e política do Paraguai, surge uma corrente de pensamento que colocará o Paraguai e seu líder como um país de grande desenvolvimento e de postura política anti-imperialista, o que mais tarde, se revelará pelo revisionismo histórico como um grande equívoco.

\begin{abstract}
Essa corrente historiográfica apresentava o Paraguai como uma potência entre os países da América do Sul. Desenvolvido e industrializado, um país com índice de analfabetismo praticamente zero, um exército permanente maior e mais bem treinado do que qualquer outro da América do Sul, extremamente disciplinado, o Paraguai teria, graças a seus ditadores que centralizaram em suas figuras todo o poder e responsabilidades possíveis, fechado suas portas à entrada do capitalismo britânico. Dessa forma, fugiu da inserção dependente no mundo capitalista, o que o tornaria mais uma nação dependente do capital estrangeiro, principalmente da Inglaterra. Por isso, Brasil e Argentina teriam sido manipulados pela Inglaterra para combater o desenvolvimento autônomo do Paraguai abrindo o mercado do país platino ao capital estrangeiro.

Dentro desse grupo de historiadores, destacamos León Pomer, historiador argentino, que publicou obras como Guerra do Paraguai: a grande tragédia rioplatense (do original "La Guerra del Paraguai: Gran Negócio!"), e Guerra do Paraguai: nossa guerra contra esse soldado. Em suas obras, Pomer traz sempre grandes estudos com ênfase na economia dos países envolvidos no conflito durante o período da guerra, com várias representações dos empréstimos por eles contraídos junto aos Bancos particulares ingleses. Para ele, a Inglaterra conseguiu aumentar a dependência de países como Argentina e Brasil, já que estes contraíram dívidas enormes com os bancos ingleses. Nas palavras do próprio autor com relação à Guerra: "O único e verdadeiro beneficiário é a Inglaterra..." (SALES, 2009:3)
\end{abstract}

No Brasil, esse discurso da guerra contra o imperialismo foi difundido pelo jornalista Júlio José Chiavenato em seu "Genocídio Americano: a verdadeira história do Paraguai" (1979), e foi difundido pelos sistemas de ensino e livros didáticos do Brasil até o início dos anos 2000. Entretanto, DORATIOTO (2002) em seu estudo intitulado "Maldita Guerra: Nova história da Guerra do Paraguai" (2002) desconstrói os argumentos com um banco de dados do período retirado do comércio exterior inglês e de arquivos históricos 
do Paraguai e Argentina e constata que a ideia do Paraguai ser um estado em pleno processo de industrialização não condiz com os documentos que comprovam o Paraguai ser um país agrário.

Sobre a questão das dívidas com a Inglaterra, é demonstrado que aquele país foi a principal apoiadora da política de militarização paraguaia, sendo a maior fornecedora de armas e tecnologia, e já possuía uma dívida com a potência europeia; "a Grã-Bretanha se beneficiaria do limitado processo de modernização paraguaio, implementado a partir de fins da década de 1850 e restrito a aspectos militares" (DORATIOTO, 2006:254). E segue uma visão doutrinadora de visão marxista, que de forma dogmática adapta a realidade a teoria criando, neste caso, uma deturpação do fato. "Tal teoria é resultado do momento histórico das décadas de 1960 e 1970, quando o mundo vivenciava a Guerra Fria" (ibidem).

\begin{abstract}
Essa teoria não se sustentou, diante de pesquisas de diferentes historiadores. Em 1983, os paraguaios Juan Carlos Herken Krauer e Maria Isabel Gimenez de Herken demonstram que, ao contrário, (...). O Paraguai importava produtos manufaturados e técnicos britânicos para operar a única ferrovia do país - ligava Assunção, a capital, ao grande acampamento militar de Paraguari -, e para outras construções de caráter militar (arsenal, fundição e obras de defesa). (DORATIOTO, 2006: 254)
\end{abstract}

Outro ponto, que trouxe celeuma entre os cronistas e mais tarde entres os pesquisadores do assunto, foi sobre quem começou a Guerra. Tal questão tem origem na investida paraguaia; Solano Lopez ataca o Brasil alegando que o Brasil havia declarado guerra e que sua ação era uma resposta ao ataque das tropas imperiais, quando de fato eram as forças paraguaias que estavam marchando sobre o território do Mato Grosso, "o governo paraguaio se apresentava como agredido, quando era o agressor" (DORATIOTO, 2002:100).

Antônio de Sena Madureira em seu livro Guerra do Paraguai, também culpa Solano Lopes pela Guerra. Segundo Sena Madureira, os brasileiros só empunharam as armas "... para repelir o inimigo que inesperada e traiçoeiramente invadiu uma de nossas mais importantes províncias, aprisionou um alto funcionário e outros súditos brasileiros...". Ainda sobre esse livro, devemos ressaltar que ela é uma resposta crítica à obra de Jorge Thompson "Guerra del Paraguay "que, segundo Sena Madureira, minimiza a atuação dos "bravos" Exércitos e Marinha do 
Brasil. Além disso, segundo Madureira, Thompson exagera em números de baixas, principalmente, pelo lado do Brasil ao longo do conflito. (SALES, 2009: 2)

O plano estratégico do Paraguai era fazer uma guerra relâmpago (ver figura 16), e buscando as regiões de Entre Rios e Mato Grosso, duas áreas pouco protegidas e ocupadas. No caso do Mato Grosso a negligência militar era tremenda. A conjuntura das forças imperiais não eram as melhores no âmbito nacional, nas áreas mais distantes dos centros urbanos a situação para defesa era precária. Solano Lopez tinha ciência dos apetrechos militares da província de Mato Grosso e sabia que com sua força tomaria rapidamente 0 território. O grande problema estratégico fora que a Argentina abriu o seu território para que as forças brasileiras pudessem passar e em troca o Brasil abriu mão de ganhos territoriais.

\begin{abstract}
A negligência militar dos gabinetes que governavam o Brasil fez com que enviassem para Mato Grosso, desde 1862, grande quantidade de armas, munições e outros artigos bélicos, sem destinar a tropa necessária para utilizá-la. Para defender a província eram insuficientes aqueles 875 soldados, dispersos por cinco distritos militares, e os seis pequenos vapores da Marinha imperial, dos quais apenas um dispunha de dois canhões. Esses navios não poderiam ser considerados de guerra, e serviam, sim, de transportes. Nesse contexto, a única e precária defesa de que dispunha o Mato Grosso, em caso de ataque paraguaio, era o forte Coimbra, construído na época colonial e estrategicamente localizado às margens do rio Paraguai, na fronteira com o país guarani. (DORATIOTO, 2002:98-99)
\end{abstract}

A guerra relâmpago contou com um serviço de inteligência e espionagem realizado pela marinha do país guarani que realizou 0 levantamento do tipo de defesa e forte e da navegação do rio. Um ano depois desse levantamento foi realizado o ataque. Conhecimento do terreno e da disposição das forças inimigas, medidas as forças e sabendo que o Brasil demoraria muito para deslocar e teria dificuldades de ter acesso pela Bacia do Prata, Solano queria ver até onde iria a aliança entre Brasil e Argentina. Seu plano estratégico funcionaria, se não fosse a coalizão de forças e a livre comunicação das linhas brasileiras por território argentino. 


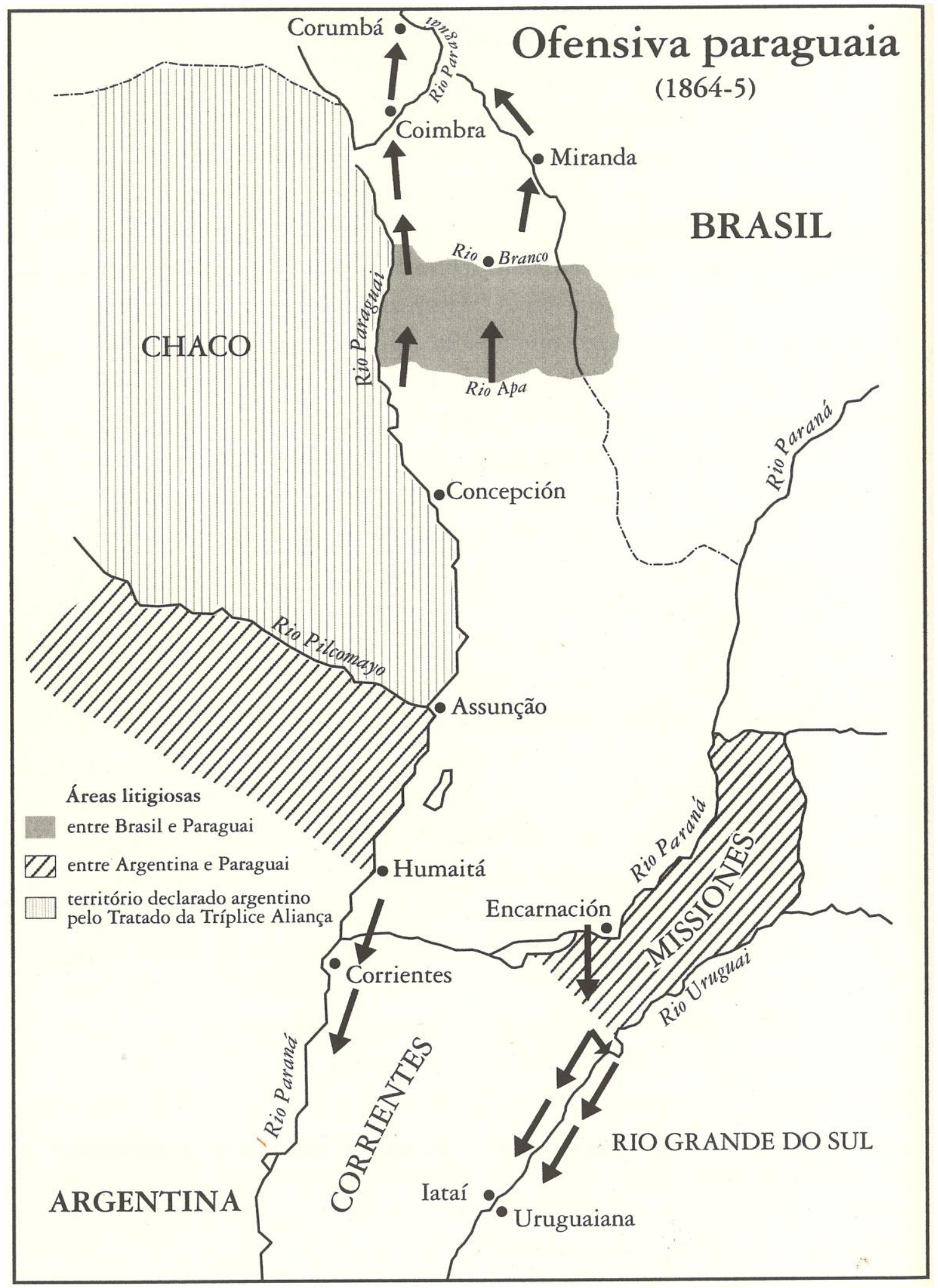

Figura 16- DORATIOTO, 2002:94. 
Do lado paraguaio, a invasão de Mato Grosso foi bem preparada, precedida do levantamento de informações por espiões. Em 1862, uma patrulha de cavalarianos paraguaios percorreu o distrito de Miranda. No ano seguinte, em abril, chegou a Corumbá o tenente André Herreras, da Marinha paraguaia, que foi recepcionado pelo comandante da guarnição militar brasileira e visitou, em seguida, o porto de Dourados, na margem do rio Paraguai. Dois anos depois, Herreras voltaria a essa região, no comando do navio Iporá, pertencente à força invasora. (DORATIOTO, 2002:99)

O plano estratégico de Caxias dividia-se em quatro eixos mestres e envolvia 50 mil homens. O primeiro eixo consiste no esforço principal sobre Humaitá e tinha como objetivo Assunção; o segundo eixo se apresenta na ação sobre Concepção que tinha por finalidade dividir as forças inimigas; o terceiro eixo é marcado pela ação sobre o rio Apa e como uma reação as tropas paraguaias que ocupavam o Mato Grosso; e, por fim, o quarto eixo, uma ação sobre Itapuã-Humaitá que tinha o propósito de dividir as forças inimigas de Humaitá e Paso de la Patria, dando segurança ao esforço principal. Um eixo principal e três eixos que forçavam o inimigo a uma Guerra em mais frentes.

A Guerra do Paraguai trouxe para o uso do campo de batalha o balão. Este foi usado não com a intenção de jogar bombas e sim de localizar as trincheiras inimigas e visualizar o movimento do inimigo no terreno. As forças paraguaias alvejavam os balões brasileiros que acabaram por ter um uso um pouco mais restrito do que se imaginava. Entretanto, as informações do campo de batalha foram essenciais para o movimento dos barcos de guerra que bombardeando de forma cega, não acertava as trincheiras inimigas desperdiçando munição e castigando a infantaria da coalizão que sempre combatia uma força quase intacta. $\mathrm{O}$ uso dos balões corrigiu os ataques dos bombardeios navais.

Em março de 1867, o governo brasileiro comprou, nos Estados Unidos, em Nova York, dois balões, um grande e outro menor, e contratou os irmãos aeronautas James e $\mathrm{E}$. $\mathrm{S}$. Allen para operá-los. Os gastos na compra dos balões e dos equipamentos para enchê-los com hidrogênio foram de 10 mil dólares. Os aeronautas e balões chegaram a Tuiuti em 31 de maio de 1867 e a primeira ascensão se deu em 24 de junho, quando um dos balões subiu a 330 metros, preso a duas cordas, seguradas por soldados em terra. Efetuaramse várias ascensões até fins de julho de 1867, mas as observações foram prejudicadas por nevoeiros e, ainda, 
pelas inúmeras fogueiras que os paraguaios faziam para dificultar a visão de suas posições.

(...)

Ao contar com o reforço do $3^{\circ}$ Corpo de Exército de Osório e com o fim da epidemia de cólera, Caxias iniciou, em 22 de julho de 1867, pela madrugada, o movimento de flanco, contornando Humaitá. Escreveu ele a José Maria da Silva Paranhos Júnior, três meses antes, que seria "um louco" se atacasse de frente as posições inimigas, onde estavam 20 mil homens "magistralmente colocados e fortificados", e sobre as quais os bombardeios da esquadra tinham pouco efeito. O marquês tinha razão duplamente, pois, de um lado, um ataque frontal às fortificações inimigas custaria 20 mil mortos e a tropa restante não seria suficiente para perseguir e derrotar Solano López de forma definitiva. De outro, os dez encouraçados fundeados entre Curupati e Humaitá dispunham de cinquenta canhões que, a cada quatro horas, bombardeavam as posições inimigas com 960 tiros por dia. Os bombardeios raramente causavam danos às posições inimigas e, ao serem iniciados, eram ridicularizados pelos paraguaios, que tocavam uma "música infernal", por toda a extensão das posições defensivas, com cornetas rústicas, feitas de chifre de boi, para irritar os chefes aliados. (DORATIOTO, 2002:295-296)

Não prática da guerra, o que entendeu o espaço geográfico melhor do que todos na construção do teatro de operações foi o Marquês de Caxias. Sem dúvida ele buscou informações da defesa estratégica paraguaia e desmontou-a a partir de uma ação onde o inimigo tinha mais fragilidades. Os conhecimentos de uma defesa estratégica têm como base a construção do saber do espaço geográfico de detalhe e de todas as possibilidades do inimigo de usá-lo a seu favor. Cortar as possibilidades do inimigo se escorar nas possibilidades do espaço é o primeiro caminho para vencer a defesa estratégica. Essa lição que foi dada pela genialidade militar de Caxias também é uma lição dada pela Geografia Militar.

O armamento usado no conflito teve como principal protagonista os rifles ${ }^{38}$, especialmente os modelos que funcionavam com o sistema Minié que era dotado de um projetil cilíndrico e cônico "que tornava as armas raiadas e de carregar pela boca mais precisas e eficientes" ${ }^{39}$. Essas armas permitiam os soldados brasileiros serem mais eficientes de longe do que os paraguaios,

\footnotetext{
${ }^{38}$ In: "Armas de Guerra", Volume 15, "Armas portáteis 1870-1950, Editora Abril 2010, p9: Rifle em inglês é a raia interna do cano. Os fuzis raiados foram, a princípio, usados apenas por unidades de infantaria ligeira, empregadas à frente do corpo principal da tropa.

${ }^{39}$ Ibidem
} 
mesmo que no começo da guerra os soldados ainda não tivessem acostumados com o uso dessas armas.

\begin{abstract}
Em vez de se aproximar para o combate corpo a corpo, o comandante brasileiro, o conde d'Eu, determinou que os batalhões operassem parcialmente dispersos no terreno. Mais importante, o fogo foi feito a alcances maiores aproveitando-se das vantagens das Miniés sobre as pederneiras paraguaias, como colocou o visconde de Taunay no Diário do Exército: as nossas armas a Minié levavam até as suas reservas [na retaguarda inimiga] à morte, ao passo que entre os nossos mais avançados soldados pouco prejuízo se dava. O resultado do uso eficaz do armamento foram as pesadas perdas paraguaias nessa batalha: 1,2 mil prisioneiros e 2 mil mortos, contra 26 mortos e 259 feridos entre os brasileiros. ${ }^{40}$
\end{abstract}

Outras armas foram usadas no conflito como aponta DORATIOTO (2002:215): 1- Fuzil Dreise, de agulha, modelo prussiano de 1857, usado pelo $15^{\circ}$ batalhão de fuzileiros na tomada do reduto do Estabelecimento e depois abandonada; 2- Clavina Spencer, usada pela cavalaria na campanha das Cordilheiras; 3- Revólver sistema Lafoucheux, usado pelos oficiais; e todos os outros rifles (clavinas, carabinas e espingardas) que funcionavam com 0 sistema Minié.

A esquadra da Marinha Imperial teve um grande diferencial em relação a força naval paraguaia: os encouraçados e fragatas - que podiam utilizar a propulsão a vapor e, ao mesmo, tempo usar a força do vento e já possuíam partes da fuselagem de ferro. Esse advento marca uma transição na questão da mobilidade das embarcações. "A mudança começou gradativamente. As naus foram adaptadas para ter a propulsão mista, de vela e vapor" ${ }^{41}$. A adaptação impedia a colocação de uma bateria de canhões, limitando a ação de destruição do artefato bélico. "A fragata Amazonas, naucapitânia brasileira do chefe de divisão Francisco Manuel Barroso, na batalha de Riachuelo, em 11 de junho de 1865" ${ }^{42}$.

Os primeiros navios encouraçados com placas de ferro foram empregados para atacar fortalezas, eliminando a vulnerabilidade dos navios de madeira, altamente incendiáveis. Navios blindados foram primeiro usados na

\footnotetext{
${ }^{40}$ In: "Armas de Guerra", Volume 15, "Armas portáteis 1870-1950, Editora Abril 2010, p9.

${ }^{41}$ Ibidem

${ }^{42}$ Ibidem
} 
guerra da Criméia (1853-1856), na guerra Civil Amerinacana (1861-1865), e na guerra do Paraguai (1865-1870) ${ }^{43}$.

A artilharia foi amplamente modernizada durante a guerra do Paraguai, embora o número de peças tenha sido muitas vezes insuficiente; a sua boa operação sempre favoreceu as forças coalizadas. Embora os números de peças criem problemas na contagem de peças os documentos de fonte primária indicam um baixo número de peças com grande calibre e força.

O primeiro deles é a diversidade de calibres, criando uma miscelânea muito maior do que na arma de infantaria, como prova o Relatório do Ministério da Guerra de 1867, ao dar o total de 104 peças ao Exército em Operações no Paraguai, sendo elas: 17 Wythwoort (em três calibres de 32, $12 \mathrm{e}$ montanha), 73 La Hitte (em quatro calibres de 12, 6, 4 e montanha), quatro obuses de calibre 14, dois obuses de montanha e oito morteiros de $220 \mathrm{~mm}$.

Depreende-se destes números que tanto as peças pesadas usadas em especial, em posições fixas, no sítio de Humaitá (as Wythwoort 32 e 12 e La Hitte 12 e os morteiros de $0 \mathrm{~m} 22 \mathrm{~cm}$ ) quanto as de campanha (todas as demais, que podiam ser facilmente tracionadas por animais rápidos, como mulas e cavalos) eram muito poucas para as variadas tarefas que a artilharia tinha que cumprir. Comentando a criação de um 4ำ corpo de artilharia, para somar força ao batalhão de artilharia a pé e os dois regimentos de artilharia a cavalo, o conde $D^{\prime}$ Eu reconhece essa carência "com o desenvolvimento que tiveram as operações por ocasião do cerco de Humaitá, este acréscimo dado a nossa artilharia a cavalo ainda assim mostrou-se insuficiente [...]" (GOÇALVES, 2009: 68)

A artilharia, além de excelência em campo, também foi marcada por grandes pensadores do teatro de operação de guerra, portanto da Geografia Militar: Mallet e Taunay por exemplo. A seguir estudaremos um dos pioneiros da Geografia Militar brasileira, figura ligada a artilharia, combateu no plano secundário das operações, mas fez análises brilhantes sobre as questões geoestratégicas da guerra do Paraguai. Assim não se pode buscar as raízes da Geografia Militar sem passar pela artilharia, principalmente no Brasil, pois este corpo do exército era formado por Engenheiros militares que em muitos casos eram os cartógrafos que estavam realizando o primeiro

\footnotetext{
${ }^{43}$ In: "Armas de Guerra", Volume 15, "Armas portáteis 1870-1950, Editora Abril 2010, p9.
} 
mapeamento de muitas áreas longínquas que ficariam mais de um século sem uma atualização ou sem simplesmente serem mapeadas.

Visconde de Taunay, engenheiro, matemático, naturalista e um dos pioneiros brasileiros da Geografia Militar.

Um caminho para que o debate seja resgatado, é analisar alguns comentaristas do período. Mesmo sabendo que eles trazem, no bojo do seu pensamento, uma carga de valores de seu momento, muito ligado ao íntimo do nascimento do nacionalismo - tanto os comentaristas brasileiros, quanto os estrangeiros -, hoje temos toda uma historiografia revisionista que cuida de alguns números ou de julgamentos injustos que estes fizeram.

As análises dos planos de guerra, da geoestratégia, da geografia local ainda podem ser muito úteis no resgate do que podemos chamar de uma Geografia Militar e Histórica no Brasil em pleno século XIX, pois esse foi momento em que esta disciplina começou a ser institucionalizada nas escolas de comando do Estado Maior em países europeus como a França, a Alemanha e Inglaterra - esses três países tiveram uma ampla influência na cultura do Brasil em todo este século.

Um campo do conhecimento não pode ser apenas atrelado a sua institucionalização, isso é engessar o pensamento ao mundo das instituições, quando o que ocorre é justamente o inverso; as instituições surgem em demanda do desenvolvimento dos variados temas pensados, portanto o caminho metodológico de um estudo ontológico da geografia deve seguir, primeiramente, o caminho da evolução do pensamento.

Temos alguns registros históricos de estudos geográficos pré1933. São clássicos da literatura nacional, como é o caso do importante relato "A Retirada de Laguna" (1871) de Visconde de Taunay e, que tem um valor teórico valioso no campo da geografia militar, assim, não pode ser completamente descartado pelos estudiosos; assim sendo escolhido para análise de seus conhecimentos práticos de geografia.

Visconde de Taunay estudou humanidades no Colégio Pedro II, onde se bacharelou em letras em 1858. No ano seguinte, ingressou no curso 
de Ciências Físicas e Matemáticas do Colégio Militar do Rio de Janeiro. Alferes-aluno em 1862, bacharel em matemáticas e ciências naturais em 1863, foi promovido a segundo-tenente de artilharia em 1864, inscrevendo-se no $2^{\circ}$. ano de Engenharia Militar, que não terminou, por receber ordem de mobilização, com os outros oficiais alunos, em 1865, no início da Guerra do Paraguai. Terminada a guerra, foi promovido a capitão e terminou o curso de Engenharia, passando a professor de geologia e mineralogia do Colégio Militar do Rio de Janeiro. ${ }^{44}$

Não é nada fantasioso intitular, ontologicamente, Visconde de Taunay como um dos precursores da Geografia Militar no Brasil; por ser naturalista de formação - é importante lembrar que o pai da geografia, Alexander Von Humboldt, não era geógrafo e sim um naturalista especializado nos fenômenos espaciais - e lecionando geologia e mineralogia na escola militar, duas ciências que o colocam como um naturalista preocupado com a perspectiva do terreno; pode-se concluir que o autor de Retirada de Laguna é um autêntico precursor da Geografia Militar.

Desta forma, "A Retirada de Laguna" (1871) apresenta aspectos genuínos da geografia militar como as análises de: estratégias, táticas, e doutrinas; comando, controle, e estruturas organizacionais; a optimização dos elementos da natureza como a terra, o mar, o ar $^{45}$; escolha de um alvo; pesquisa e desenvolvimento; o fornecimento e alocação de armas, equipamentos e roupas; além dos suprimentos, manutenção, construções, suporte médico e treinamento.

No entanto, mesmo apresentando todos os elementos técnicos que são os fundamentos da Geografia Militar, o autor realiza sua obra em tom de narrativa. Cabe aos pesquisadores a sensibilidade de identificar elementos narrativos e analisá-los teoricamente e não, simplesmente, descartá-los da discussão acadêmica. $O$ resgate destes pensadores é de grande importância

\footnotetext{
44 In: http://www.academia.org.br/abl/cgi/cgilua.exe/sys/start.htm?infoid=97\&sid=170 (acessado em 01/07/2011).

${ }^{45} \mathrm{Na}$ Guerra do Paraguai se fez uso de balões; não obteve grande sucesso nas operações militares, porque os balões eram muito vulneráveis nas áreas de imensas planícies, eram alvos fáceis na linha de tiro do inimigo.
} 
abordá-los e incluí-los nos debates acadêmicos da geografia enriquece ainda mais as discussões.

Não podemos analisar um autor sem colocá-lo em seu contexto. Taunay é um legítimo representante de seu tempo. Naquele momento histórico os homens não se limitavam em especializações, eles eram polivalentes. Taunay era um literato, escreveu alguns romances, e o mais eminente foi "Inocência", que foi um corolário de seu tempo na literatura e permanece como um clássico da literatura nacional. Ele foi, também, um conhecedor profundo da matemática e da física. Foi professor de mineralogia e geologia, e engenheiro militar.

Em seu clássico, "A Retirada de Laguna" (1871), observa-se que existe um real valor literário e que não se trata apenas de uma composição técnica sobre a Guerra do Paraguai. É uma narrativa de um episódio de guerra, que tem a intenção de informar o Imperador e o alto escalão do exército, fornecendo-Ihes informações valiosas do conflito, mas sem perder o caráter de literatura, sem perder o estilo literário.

Sua obra reflete justamente isto - um homem polivalente do século XIX e a grandeza literária de seus textos -, mas é bom nos lembrarmos de que mesmo em seu tempo nem todos conseguiram ser tão polivalente, quanto Taunay fora. A seguir temos as indicações do que ficaria para posteridade como fonte de informação e arte na visão do próprio autor.

Nestes dois documentos [O Relatório Geral da Comissão de Engenheiros e a Retirada de Laguna], e em diversas partes, das Histórias Brasileiras e Narrativas Militares, encontram-se todas as informações, já sistematizadas, já escritas ao correr da pena e do capricho, a respeito daquelas forças de Mato Grosso que tanto e tão inutilmente sofreram e de cujas aventuras dramáticas e até trágicas não restaria hoje o mais leve sinal, a mais apagada lembrança, se eu as não tivesse talvez para sempre! - livrado do esquecimento.

Talvez para sempre, pode parecer imodéstia de minha parte; mas não sei, nutro a ambição de que hão de chegar à posteridade duas obras minhas, a Retirada de Laguna e Inocência... Quem me dera à segurança de Horácio, a convicção do grande cinzelador de versos impecáveis - Nom ominis moriar! (TAUNAY apud MARETTI, 2006: 273) 
Esse espírito do homem do século XIX está presente nesta breve autoanalise do Visconde, um homem da ciência e das artes ao mesmo tempo combinando uma com a outra de forma livre, pois a ciência ainda não dava tantas respostas como nos dias de hoje, gerando uma séria de lacunas que eram preenchidas muitas vezes pela intuição, por um julgamento dos homens da época e até com um mergulho mais profundo nas raízes da questão fazendo análises conjunturais bem realistas para um cronista que vivia os acontecimentos narrados.

\section{A Retirada de Laguna: uma análise de geoestratégica a partir de um teatro secundário de operações da Guerra do Paraguai.}

No primeiro capítulo, intitulado "Formação de um corpo de exército destinado a atuar, pelo norte, sobre o Alto Paraguai. Distâncias e dificuldades de organização", Taunay desenvolve uma série de análises geoestratégicas. A primeira análise advém do questionamento: por qual caminho seria mais prudente atacar os exércitos paraguaios, pelo sul ou pelo norte? A resposta advém de análise geográfica:

\footnotetext{
Ao sul oferecia o caudaloso Paraguai mais vantagens à expugnação da fortaleza de Humaitá, que, pela posição estratégica do país, assumindo, nesta porfia encarniçada, a importância de Sebastopol, na Campanha da Criméia. (TAUNAY, 1952: 21)
}

Taunay acreditava que $o$ ataque pelo sul daria mais vantagens ao defensor do que ao atacante, visto que era necessário subir o caudaloso rio Paraguai e que os paraguaios, por sua vez, acreditavam que a aliança Brasil, Argentina e Uruguai - por uma questão de deslocamento e de concentração de tropas e população - concentraria sua empreitada militar pelo sul; fazendo da fortaleza de Humaitá a mesma importância de Sebastopol na Guerra da Criméia 1852.

DORATIOTO (2006) aponta que "as características geográficas do Paraguai restringiam as opções de invasão dos aliados, pois faziam com que a navegação do rio Paraguai fosse a única via de acesso a Assunção" e que por sua vez esta navegação era "controlada pela fortaleza de Humaitá e a 
estratégia aliada exigia que os navios brasileiros e as tropas aliadas anulassem a poderosa fortificação" (ibidem, 2006:264).

A análise do Visconde traz consigo uma comparação que não pode ser ignorada: a fortaleza de Humaitá e Sebastopol. O cerco de Sebastopol (1854-55) na Guerra da Criméia (1853) seria um acontecimento bélico e sangrento enormemente alarmante no mundo europeu até meados do século XIX. As semelhanças são importantes, embora o autor não as cite, esperando que o leitor as conhecesse; não é por menos este conflito foi muito comentado em seu período.

A Guerra da Criméia é um conflito de uma potência terrestre contra aliança de três outras potências marítimas: Rússia contra Grã-Bretanha, França e Piemonte. O principal objetivo da potência terrestre emergente era uma saída ao mar mediterrâneo pelo mar negro; já a aliança pretendia obstruir as pretensões russas e permanecer com seu condomínio no mar mediterrâneo e, assim, não dividindo com mais uma potência o seu poder regional.

No continente sul-americano, observa-se uma situação muito semelhante na Guerra do Paraguai: uma potência terrestre emergente em sua região, o Paraguai; contra uma aliança de três potências regionais marítimas, Brasil, Argentina e Uruguai. A intenção paraguaia era estabelecer uma ponte que possibilitasse sua saída para o mar através da Bacia do rio da Prata.

A comparação sobre a aliança é, quase, perfeita do ponto de vista das dimensões espaciais, políticas e militares - com sua devida proporção nos três aspectos.

O Brasil, da tríplice aliança, assemelhava-se a Inglaterra: era uma potência marítima, embora não fosse propriamente uma ilha, essa sempre fora uma designação representativa do Brasil, "Ilha Brasil"; são vários os motivos para tal alcunha, culturalmente é o único em sua região a falar o português e no aspecto físico é delimitado por duas enormes bacias hidrográficas - Bacia Platina e Bacia Amazônica - que praticamente são "mares" que os separa de seus vizinhos. Do ponto de vista político, o liberalismo. A influência do partido liberal na corte brasileira, durante o confronto com o Paraguai, foi uma das tônicas na política brasileira. 
A Argentina se assemelhava à França, não tinha uma força marítima tão forte quanto à brasileira, mas abarcava o status de potência regional anfíbia. Do ponto de vista político, a guerra civil argentina proclamava uma revolução liberal evocando pretensões de uma revolução republicana liberal, quase uma revolução francesa aos olhos dos argentinos.

Por fim, o Uruguai, o menor estado e menos expressivo, assemelhava-se a Piemonte, por ambos serem pequenos e representarem 0 aspecto geopolítico de estados tampões. Os estados tampões são aqueles que impedem a expansão de outros em sua região. No caso sul-americano a criação da nação uruguaia impediu as pretensões brasileiras, que eram 0 domínio da parte oriental da bacia do rio da Prata e, também, as pretensões argentinas, que se fixavam no domínio total da foz da bacia. A criação do estado tampão foi uma idealização política britânica, que colocava um fim a disputa entre Brasil e Argentina (na época chamada de Províncias Unidas do Rio da Prata).

\begin{abstract}
A independência do Uruguai havia sido viabilizada pela interferência britânica, após três anos de guerra (1825-28) entre o Império do Brasil e as Províncias Unidas do Rio da Prata pela posse desse território, que fora anexado por D. João VI ao império luso-brasileiro. Após a independência, surgiram no Uruguai os partidos Colorado e Nacional ou Blanco. Os colorados tinham como base social principalmente os comerciantes de Montevidéu e defendiam o livre comércio e a livre navegação dos rios platinos. Estes eram princípios também defendidos pela política externa brasileira, pois a província de Mato Grosso estava isolada por terra do resto do Brasil e a única forma de o Rio de Janeiro manter contato regular com ela era por meio da navegação fluvial: navios penetravam no estuário por Assunção, até chegar a Cuiabá. (DORATIOTO, 2006: 257).
\end{abstract}

Ainda comparando a Guerra do Paraguai (1864-1870) com o conflito europeu citado, o Brasil realizou até um jogo político muito semelhante ao que fez a Inglaterra quando se aliou à França de Louis Napoleão III. Os ingleses convenceram os franceses que ao se aliarem teriam a possibilidade de realizar uma campanha na península balcânica assim como já havia feito, algumas décadas anteriores, a França napoleônica. Já o Brasil submeteu o seu comando, mesmo sendo a principal força da tríplice aliança, ao general argentino Mitre para que as forças aliadas não acusassem o Império brasileiro 
de usar a guerra como pretensão a um projeto expansionista, como descreve DORATIOTO (ibidem, 2006:263):

\begin{abstract}
A maior responsabilidade cabia ao Império do Brasil, por ser, entre os aliados, o país com maior população, mais recursos materiais e financeiros, bem como o único a possuir uma verdadeira Marinha de Guerra. Apesar de ser o Brasil o aliado mais poderoso militarmente, ainda assim o comando-em-chefe do Exército da Tríplice Aliança coube ao general Mitre, por considerações de ordem política. Para o Império, o comando do presidente argentino era uma forma de demonstrar, aos demais países, que não havia na guerra intenção expansionista brasileira.
\end{abstract}

Outra semelhança, entre os confrontos e combates comparados, é o fato de ambos terem sido guerras navais apoiadas por infantarias. Os navios com canhões poderosos eram usados para romper as fortalezas inimigas, além de causar baixas nas tropas defensoras. As infantarias atacavam posteriormente aos bombardeios navais e buscavam uma posição de ocupação.

O uso das trincheiras fora realizado nessas guerras, mas com funções diferentes. No cerco de Sebastopol (1854-55), o engenheiro-chefe britânico John Burgoyne construiu trincheiras para que os franco-atiradores pudessem operar sem grandes riscos. Já na batalha de Curupati, afirma Doratioto (2006) as trincheiras foram feitas pelos paraguaios que se protegeram dos bombardeios da Marinha Imperial e puderam contra-atracar as forças terrestres da tríplice aliança em igualdade, estima-se que morreram entre 4 mil a 9 mil soldados da aliança nessa investida.

Ao que tudo indica, a grande diferença entre o Cerco de Sebastopol e o ataque as fortalezas paraguaias é que, no primeiro caso, a conjugação de força dos defensores, em boa parte do conflito, fora tão importante quanto à dos atacantes - as forças militares disponíveis para a defesa eram de 4500 milicianos, 2700 artilheiros, 4.400 marinheiros, 18.500 fuzileiros-navais e 5000 auxiliares de serviço, totalizando pouco mais de 35000 homens.

Enquanto que no caso do conflito sul-americano, as forças atacantes quase sempre foram superiores em armas e homens, demonstrando 
muitas vezes falhas nas manobras ofensivas, sendo que isto custou a vida de muitos combatentes. Brasil e Argentina eram os países mais populosos do conflito. A população estimada do Paraguai era de 650 mil habitantes, a do Brasil era de cerca de 9.100.000 habitantes, a da Argentina, cerca de 1.737.000 habitantes, e a do Uruguai, perto de 250.000 habitantes.

Embora o terreno ao sul e sudeste do Paraguai fosse complicado para as tropas atacantes, favorecendo a defesa; ao norte a escassez de infraestrutura, de população e o isolamento da área em relação aos centros dinâmicos do país deixavam esta opção numa segunda perspectiva - é exatamente sobre este caminho que se trata "A Retirada de Laguna".

\section{“A Retirada de Laguna”, a Geografia Militar Narrativa.}

Retomando a pergunta: "por qual caminho seria mais prudente atacar os exércitos paraguaios, pelo sul ou pelo norte?" Para Taunay, a resposta advinha de sua convicção e experiência em campo. Pelo norte a guerra teria sido mais rápida e esse teria sido o plano original da Tríplice Aliança, mas a mobilização dos esforços teria sido maior, como diz em sua afirmação sequente:

Ao norte, do lado do Mato Grosso, eram as operações infinitamente mais difíceis, não só porque ocorriam a milhares de quilômetros do litoral atlântico, onde se concentram todos os recursos do Brasil, como ainda por causa das inundações do rio Paraguai, que cortando na parte superior do curso terras baixas e planas, transborda anualmente, a submergir então regiões extensíssimas. Consistia o plano de ataque mais natural em subir as águas do Paraguai, do lado da Argentina, até o coração da república inimiga e, do Brasil, descê-las a partir de Cuiabá, a capital mato-grossense que os paraguaios não haviam ocupado.

Teria impedido à guerra arrastar-se durante cinco anos consecutivos esta conjugação de esforços simultâneos. (A Retirada de Laguna: 21-22).

Os acontecimentos históricos revelaram que a grande Guerra sulamericana teria o esforço, por parte da tríplice aliança, concentrado ao sul do Paraguai, região na qual não favorecia os atacantes, assim como o caminho pelo norte, mas era o caminho mais natural a ser feito, tanto pelo Brasil, quanto 
pela Argentina, pois toda a sua organização sócio-espacial remetia o seu esforço de guerra por aquele caminho (ver a figura).

O sul e o sudeste do Paraguai eram territórios com extensos trechos alagados, o que favoreceu a ação defensiva dos soldados paraguaios, que conheciam as trilhas e podiam entrincheirar-se nas posições mais favoráveis para emboscar e resistir aos invasores (DORATIOTO, 2006: 265).

$\mathrm{Na}$ narrativa, fica claro que os paraguaios não acreditavam que o Brasil tivesse condições de atacar pelo norte, por isso, não tiveram tanto cuidado em realizar uma defesa bem estruturada nesta fronteira, assim concentraram todas as suas esperanças na defesa ao sul, "as fortificações do Apa não passavam de simples estacas de madeira comum, guarnecidas, em Bela Vista, por uma centena homens." (TAUNAY, 1952:45). Bela Vista e Laguna eram as regiões mais bem defendidas da região, segundo Taunay, os outros fortes estavam em piores condições defensivas.

Sobre a análise dos planos de guerra e de sua crítica implícita em "A Retirada de Laguna", é perceptível que o Brasil teve, nesta guerra, mais uma possibilidade não aproveitada de integrar e desenvolver seu território. Preferiu o caminho mais fácil e que de certa forma ia pelo mesmo sentido do pensamento das elites dirigentes do país e de seus interesses regionais. Não se escolheu a alternativa pelo sul porque era mais interessante do ponto estratégico, logístico ou de inteligência, mas porque havia interesses políticos regionais e interestatais. 


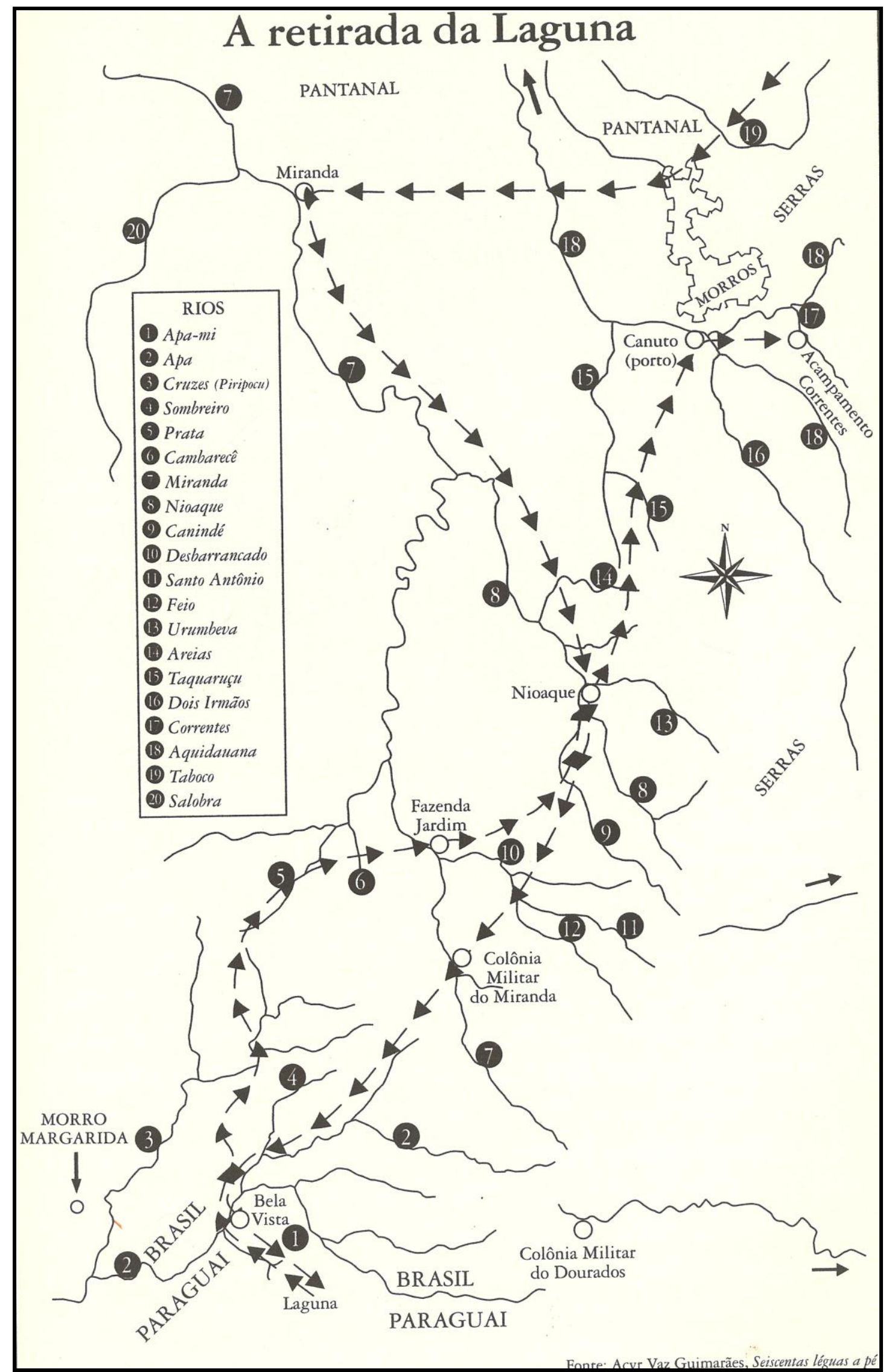

Figura 17 - DORATIOTO, 2002:125. 
$\mathrm{Na}$ defesa territorial, qual era o principal ponto fraco das fronteiras entre o Brasil e o Paraguai? Eram as fronteiras do norte, onde havia uma população escassa e deixada a própria sorte e que sofria sempre com as invasões dos "castelhanos" - estas bem anteriores a Guerra do Paraguai - e que defendiam o seu território sem apoio nenhum do Estado brasileiro.

Este foi o caso de caso de Dona Senhoria que, viúva, cuidou de seus filhos nos remotos quinhões daquelas áreas alagadas como conta Taunay (1952: 50):

\begin{abstract}
Residindo só, com os filhos, então crianças, numa zona fronteiriça, onde não há mínima segurança para os fracos, já fora outrora levada por um magote de paraguaios. Reclamada, ao cabo de algum tempo, pela legação brasileira em Assunção e liberta em 1850, contraíra, segundo o costume generalizado naquela terra, segundo casamento com o cunhado, o nosso guia, que a estabelecera em sua estância do Jardim. Ali, ao começar a invasão, de 1865, fora de novo presa e internada no Paraguai.
\end{abstract}

Sobre a questão da fragilidade paraguaia na fronteira com o Mato Grosso, a narrativa aponta que os paraguaios, sabendo da movimentação brasileira nestas cercanias, não seriam capazes de enfrentar frontalmente a expedição comandada brasileira e começaram a recuar e utilizar a técnica da terra arrasada. "Recuaram os paraguaios em boa ordem. Tinham ordens, certamente, para não empenhar combate, mas somente reunir e tanger a retaguarda cavalos e bois que não queriam deixar-nos" (TAUNAY, 1952:57).

Essa técnica da terra arrasada consiste na retirada e no incêndio e tem como exemplo histórico clássico os cossacos que incendiaram Moscou antes da invasão napoleônica. "Das oito ou dez casas da Machorra, duas estavam reduzidas a cinzas pelo fogo que os próprios paraguaios thes havia posto" (TAUNAY, 1952: 58). Outro comentário sobre este fato, da terra arrasada, vem com a tomada do forte de Bela Vista e com as palavras do Cel. Camisão: "A perdiz disse-nos, voa do ninho e nada nos quer deixar, nem os ovos. São as casas de Bela Vista que incendiaram" (ibidem, 1952:61).

Estes relatos - das tomadas das fortificações da Machorra e de Bela Vista - demonstram que o pensamento de Taunay não parecia tão 
ilusório, talvez a guerra tivesse sido mais rápida ao empenhar forças pelo norte e o confronto frontal tivesse sido amenizado ao dividir as forças paraguaias em duas frentes. O Brasil não deu apoio necessário às forças do norte com poucos homens e inadequadamente equipadas.

Outro ponto da narrativa que remete ao conceito da geografia militar é a explícita falta de conhecimento do terreno por parte do exército e seu Estado Maior. A morosidade em estacionar em lugares que não eram aptos, tanto para defesa, quanto para movimentação. Todas essas análises estão presentes na narrativa de Taunay.

A falta de conhecimento da geografia do lugar é um dos pontos que mais impressionam neste relato; as baixas por doenças típicas de áreas alagadas demonstram a falta de preparo e de conhecimento aplicado da geografia. $O$ exército ficou muito tempo em Miranda, localidade mais afastada no sentido norte da fronteira com o Paraguai - portanto seguro das forças paraguaias - para arregimentar soldados. Esta localidade não apresentava condições favoráveis de salubridade para os soldados, pois se encontra nas regiões inundáveis do pantanal, tão pouco era segura para a defesa caso alguma força inimiga chegasse naquelas longínquas terras.

A descrição deste caso é feita por Taunay (op.cit. 1952: 26)

É Miranda quase inabitável, rodeada como se acha, e numa extensão considerável, de depressões que a menor chuva, num instante inunda, até mesmo na melhor estação, e que os raios solares, com a mesma rapidez, enxugam. Privada de boa de água, pois a do Miranda é sempre agitada e lodosa, a disposição do terreno não oferecia ali, aliás, nenhuma das condições militares às quais, em rigor, poderiam ter sido sacrificadas as condições higiênicas. E, com efeito, ao longo de um caudal, acessível a grandes embarcações, estendem-se margens uniformemente baixas a que tiram toda a segurança estradas abertas.

Frequentemente e energicamente pronunciara-se a comissão de engenheiros contra maior demora neste foco de infecção; e já, por duas vezes o assinalara o chefe da junta médica como causa da ruína da expedição; pois de contínuo diminuía o seu pessoal, quer pela morte, quer pela dispensa.

Não só ocorreram as baixas de bons soldados com esta estação em Miranda, mas as perdas dos cavalos foram enormes e a cavalaria ficou 
completamente desmontada, pois quase todos os animais não resistiram, ocorrendo uma epizootia, que se propagou devido aos terrenos alagados: "composta de homens de nossa cavalaria desmontada (...) já relatamos que não tínhamos mais cavalos, todos vitimados na região de Miranda por uma epizootia do gênero paralisia" (TAUNAY, 1953: 48).

Sobre o uso de cavalaria em terrenos planos, Taunay tece um comentário que é a expressão de uma análise da Geografia Militar. Em terrenos muito planos e amplos a vantagem é da cavalaria, "pela nossa pequena força atirada, sem cavalaria alguma, em vastas planícies encharcadas, onde todo homem a pé é assunto de escárnio" (ibidem, 1953:54).

Com ausência: da cavalaria, de armamentos, de efetivo adequado de homens, conhecimento do território - tanto o brasileiro quanto do inimigo -, assistência médica; aquelas forças tiveram uma importante participação no conflito como um todo, pois forçaram os inimigos a se preocupar com suas fronteiras ao norte. Mas não foi decisiva para o resultado final da Guerra e, sim, de suma importância para o desenvolvimento do estudo de Geografia Militar que se pode observar na obra do Visconde de Taunay. A Retirada de Laguna já apresenta substrato de um estudo incipiente de Geografia Militar, com um conhecimento técnico muito bom e análises preciosas.

\section{Max von Versen, o olhar da escola prussiana sobre o teatro de operações da Guerra do Paraguai.}

Em História da Guerra do Paraguai, Max von Versen, militar prussiano que veio acompanhar a batalha do lado dos paraguaios, pode se encontrar uma análise breve do teatro de operações do confronto entre a coalizão e as forças paraguaias. Esta análise do autor prussiano é carregada de algumas imprecisões e julgamentos tendenciosos em relação aos homens das forças brasileiras que são sempre analisados como inferiores e sem qualidades para uma guerra. No entanto, von Versen não poderia ter tanta certeza de muitas das situações de guerra por ter sido detido em boa parte da guerra no Rio de Janeiro e em Buenos Aires, o que deixou as críticas sobre o Brasil ainda mais duras. 
Na edição da Editora Itatiaia e Edusp, da coleção Reconquista do Brasil organizado por Mario Guimarães Ferri em 1976, é comentado na Apresentação do livro pelo próprio Ferri que o General E.A. da Cunha Matos, que conheceu o prussiano numa prisão de Humaitá e de lá escaparam juntos, rebate as críticas de Versen sobre sua prisão no Brasil e sobre o ímpeto dos soldados brasileiros e a moral da própria pátria, endossado pela nota de apresentação de Ramiz Galvão, segue os dois comentários.

E, afinal, o Governo Brasileiro, segundo o General Cunha
Matos, tinha toda a razão: von Versen, oficial do exército da
Prússia, salientara-se bastante na guerra conta a Áustria,
em 1866 e desejava "assistir à guerra do lado de Lopez,
cercando a viagem de mistérios" o que "não podeia deixar
de causar séries suspeitas, e ao governo do Brasil cumpria
impedir fosse ele dirigir a guerra contra nós" (FERRI, apud
VERSEN, 1976: 11)

Há em sua minuciosa narrativa apreciações e frases, que não correspondem à justiça, mormente no que respeita ao nosso país e aos nossos homens; ainda assim, ela constitui um documento valioso que devemos acrescentar a tudo quanto há conhecido sobre essa tremenda luta em que o povo paraguaio vencido demonstrou qualidades apreciáveis de valor, e nós os aliados vencedores não demonstramos menores predicados de tenacidade e heroísmo. (GALVÃO, apud VERSEN,1976)

Uma série de viajantes europeus faz um mau julgamento do povo brasileiro e de suas capacidades. De acordo com FERRI (apud VERSEN, 1976), "Saint-Hilaire já chamou atenção para o fato, com relação a naturalistas que nos visitaram (...) e que, por ignorância ou por má fé, (...), apresentaram um panorama que não era favorável ao nosso povo e ao nosso País". É bem verdade, que nosso país é bem controverso e sempre despertou julgamentos dos mais injustos pelos analistas estrangeiros.

Nos primeiros capítulos, Max von Versen faz um relato sobre sua viajem de Berlim ao Rio de Janeiro e sobre suas prisões na capital do Brasil e da Argentina. Consequentemente, no capítulo VII, "Fatos concernentes aos Estados Platinos e a Lopez". O prussiano realiza algumas análises iniciais apresentando o tamanho da população e do território dos quatro países.

Sobre a Argentina o autor compara o seu tamanho e de sua população com a Prússia. "Este país é 4 vezes maior do que a Prússia: no 
entanto o número de habitantes não passa de 1 1/2 milhão". (VERSEN, 1976: 48). Sobre o Uruguai, o menor país do conflito a comparação é feita com o Estado da Baviéra. "É a mais pequena das repúblicas sul-americanas e assim mesmo é quase 3 vezes maior do que o Reino da Baviéra: a população é de cerca de 250.000 almas". (ibidem, 1976:49). Sobre o Brasil, o maior país do confronto o autor afirma. "Compreendendo área de cerca de 8.000 .000 de km², o território do Brasil é 24 vezes maior do que o da Prússia. (...), a população é orçada em cerca de 11 milhões de habitantes que, na maioria, ocupam regiões da zona marítima" (ibidem, 1976:32). É um dado preliminar, porém fundamental para análise inicial da Geografia Militar.

O oficial prussiano faz a mesma análise de população e território e mede as forças do Paraguai e de sua posição em relação a Tríplice Aliança.

\begin{abstract}
Completamente isolado do mundo no centro da América Meridional e contando apenas insignificante população de 900.000 almas, este pequeno país soube resistir 5 anos a três coligadas, cuja população subia de 12 a 13 milhões de habitantes: foi uma luta desigual, de 1 contra 15, luta na qual tomaram parte todos os homens, até crianças de 10 anos e também mulheres. (VERSEN, 1976:50)
\end{abstract}

A relação econômica e militar do Paraguai com o Brasil e com a Inglaterra é posta nas análises de von Versen. Neste ponto, está de acordo com a crítica que DORATIOTO (2002) faz ao teórico CHIAVENATO (1979) sobre a ideia que a Inglaterra empreendeu a guerra para impedir a industrialização do Paraguai, quando de fato a industrialização paraguaia era no setor militar e o principal parceiro comercial era a própria Inglaterra e boa parte do apoio para construção de fortaleza de Humaitá fora realizada por engenheiros brasileiros. É apontado pelo prussiano o fato de Solano Lopez ter sido educado militarmente na Europa e ter se impressionado com a Guerra da Crimeia como é posto no excerto a seguir.

Encarregou engenheiros brasileiros de construírem a fortaleza de Humaitá e mandou edificar o arsenal de Assunção. Para o ministro da guerra designou seu filho mais velho, Francisco Solano Lopez, que, durante dois anos esteve na Europa em missão militar. A entrada do exército francês em Paris, depois da Guerra da Crimeia, causou grande impressão em seu jovem espírito e talvez despertou- 
Ihe o desejo de figurar, qual outro César, na cena política da América meridional. (ibidem, 1976:52)

Mandou concluir a fortaleza de Humaitá, comprou na Inglaterra algumas centenas de canhões e grande cópia de munições e contratou para cima de 30 trabalhadores ingleses para o arsenal de Assunção, conseguindo, deste modo, ficar com condições de fabricar munições, de fundir e de raiar peças de artilharia. (ibidem, 1976: 54)

Em relação ao tipo de armamento, o autor comenta sobre as espingardas de agulha prussianas, que era muito conhecida do exército brasileiro, e, este tinha até um batalhão especial com este tipo de armamento. Os paraguaios tinham batalhões armados com clavina raiadas à Mine, enquanto a cavalaria brasileira já dispunha de clavinas de repetição Spencer. É claro que uma comparação do Paraguai com a Prússia é sempre realizada pelo autor, suas preferências estão relacionadas com as características da organização autárquica e dotada de uma relevante militarização que se observa no Paraguai é, razoavelmente, semelhante ao sistema político da sociedade prussiana, que não era dotada da democracia liberal e apresentava uma sociedade altamente militarizada.

O seu conhecimento da geografia do teatro de operações da guerra é bem limitado e tendencioso, mas alguns pontos, principalmente aqueles que falam da movimentação das forças do Paraguai são bem estruturados e dignos de notas. Von Versen e seu trabalho já fora diretamente analisado por Rio Branco, Cunha-Matos e outros, em caso de dúvidas foram consultadas as notas e principais comentários. Os excertos a seguir passaram por um minucioso cuidado.

\section{O Atlas Histórico da Guerra do Paraguai de Emilio Jourdan}

A maior contribuição cartográfica feita no período posterior a Guerra do Paraguai foi o Atlas Histórico da Guerra Do Paraguai (1871). É um trabalho que foi uma grande referência para os estudiosos, pois nele estão as plantas dos principais fortes mais importantes do conflito e disposição das forças nas batalhas de conquistas dos mesmos. Seu trabalho é importantíssimo para história da cartografia nacional, pois nele encontra-se informações sobre a topografia do terreno. 
O Atlas Histórico da Guerra do Paraguai, por Emílio Jourdan aparecido em 1871, no Rio de Janeiro, é hoje não só uma raridade bibliográfica, como uma verdadeira preciosidade. A ele tem recorrido todos os historiadores mais rigorosos no estudo das operações militares desta guerra. $\mathrm{O}$ autor fez parte da comissão faz parte da comissão de engenheiros que acompanhou o exército de operações do Paraguai. Como se sabe, os componentes da comissão de engenheiros, entre outras missões tinham a de fazer levantamentos topográficos, já que o país era inteiramente desconhecido e desprovido de recursos cartográficos aliás, como todos os países sul-americanos. (PAULA CIDADE, 1959:182)

Ver a seguir alguns croquis (figura) feitos a partir das imagens e informações contidas no Atlas.

Nota-se que PAULA CIDADE diz ser a obra rara, embora ainda não seja fácil encontrar a obra original, hoje os mapas do referido Atlas se encontram digitalizado e online (http://www2.senado.leg.br/bdsf/item/id/221684 - acessado 13/01/2015).

\section{Richard Burton: o olhar inglês sobre a Guerra do Paraguai.}

O geografo inglês Richard Burton é o exemplo do que era um cientista social e naturalista típico do século XIX. É um daqueles homens que marcaram sua época. Ele foi responsável pela grande viagem em busca das nascentes do Nilo, representando a Academia Real de Geografia na Inglaterra. Burton pode ser encarado como um ícone dos exploradores europeus do século XIX. Esteve na Índia, África e foi cônsul em Santos no Brasil.

Seu autor, o inglês Richard Francis Burton (1821-1890), foi militar, diplomata, cientista, naturalista e autor de mais de 30 livros. Um autêntico vira-mundos, explorador de vida movimentada e romanesca, era, ao tempo, cônsul inglês em Santos e deixou, sob a forma epistolar, um excelente trabalho sobre a guerra. $\mathrm{Na}$ obra intitulada Cartas dos Campos de Batalha do Paraguai, Richard Burton - muitas vezes confundido com o ator de cinema seu homônimo reuniu 27 missivas; a primeira datada de Montevidéu em 11 de agosto de 1868, e a última escrita em Buenos Aires em 21 de abril de 1869, depois de visitar os campos de batalha por duas vezes (de 15 de agosto a 5 de setembro de 1868 e de 4 a 18 de abril de 1869). As informações do autor são de um verdadeiro repórter e vêm preencher algumas importantes lacunas na memória da guerra, avassalada nos últimos tempos por um revisionismo maniqueísta, tendencioso e ideológico. As apreciações do autor sobre as 
operações militares e sobre o teatro da guerra são complementadas e enriquecidas por importantes dados sobre os principais personagens e sobre o Paraguai. (TORRES, 2006)

Burton foi o primeiro analista da guerra do Paraguai que iria questionar o grau de desenvolvimento do país guarani; ou seja, fazendo uma discussão que será o cerne do grande debate das causas do conflito. Esse debate irá se estender até o início do século XXI com os trabalhos publicados de DORATIOTO (2002).

O livro do escritor britânico (...) fornece elementos insuspeitos para desmascarar certas falsificações históricas que, como um vírus, têm contaminado os livros didáticos, aonde os jovens brasileiros vêm estudando nossa história. Particularmente sobre dois aspectos que vêm sendo explorados pelo revisionismo, o livro de Richard Burton fornece elementos de pesquisa e ponderada reflexão: a falácia do genocídio paraguaio e a versão fantasiosa de que a economia do país vizinho era tão próspera e poderosa, ao ponto de causar arrepios nos ingleses que, por isso, a resolveram destruir, com a ajuda subserviente de brasileiros e argentinos. (TORRES, 2006)

De acordo com TORRES (2006), outro aspecto mencionado pelo geógrafo inglês são os números estatísticos do Paraguai, isto sensivelmente mostra que o genocídio de mais de 1.5 milhão de pessoas tem cifras mais modestas. Burton busca os dados dos sensos do final do século XVIII e início do XIX e calcula o crescimento vegetativo do país estimando números bem realistas sobre a população do Paraguai.

A começar pela capital, Assunção, a que atribui, em 1857, uma população de 12 mil almas, quando alguns autores a estimavam em 15, 20 e até 48 mil habitantes, assinalando Burton que: "onde os limites de um país são traçados com imprecisão, sabemos bem o que pensar de seus recenseamentos. 

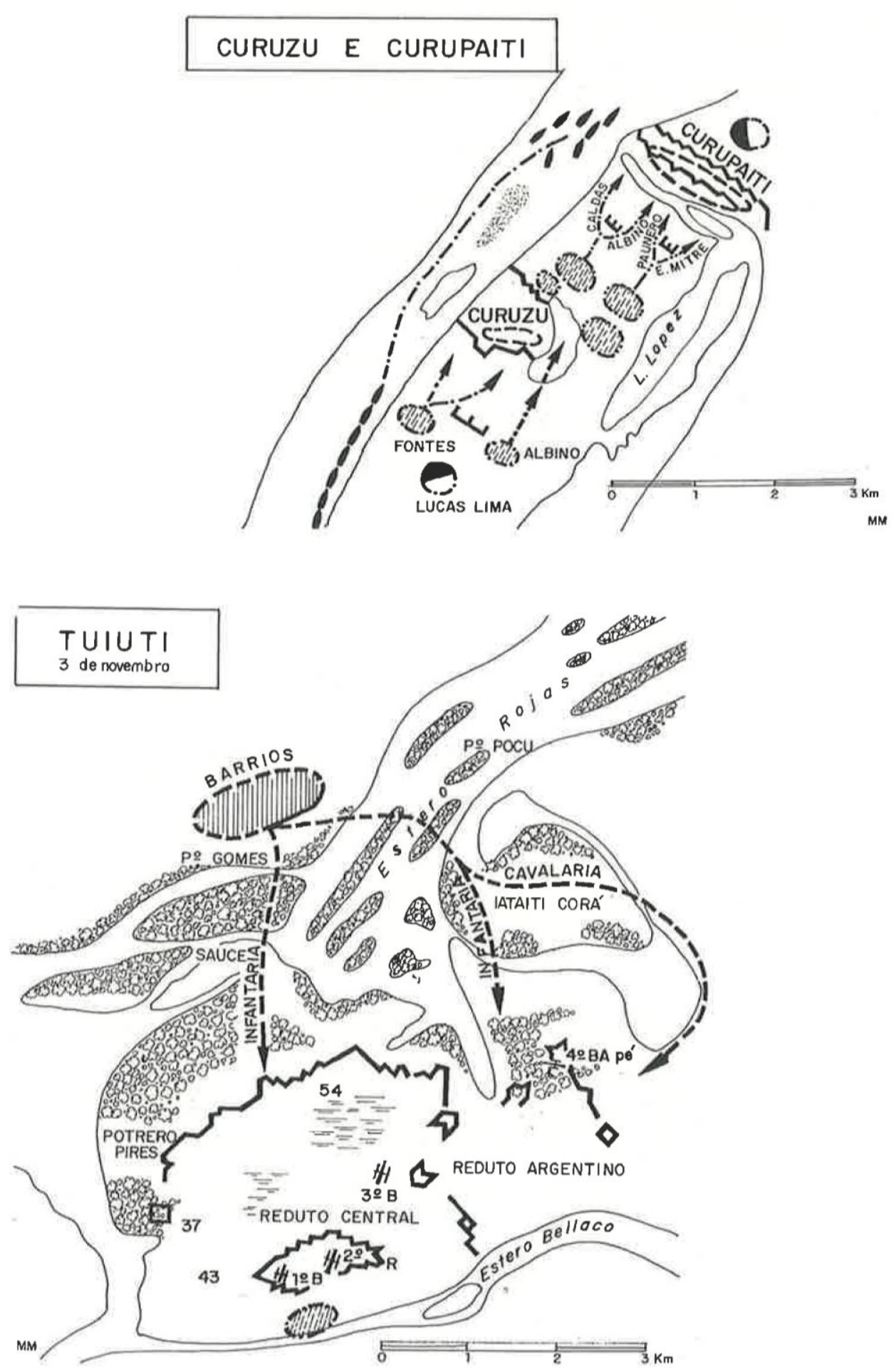

Figura 18 e 19 - Fonte: FERREIRA ALVEZ,1979: 149; 153. 


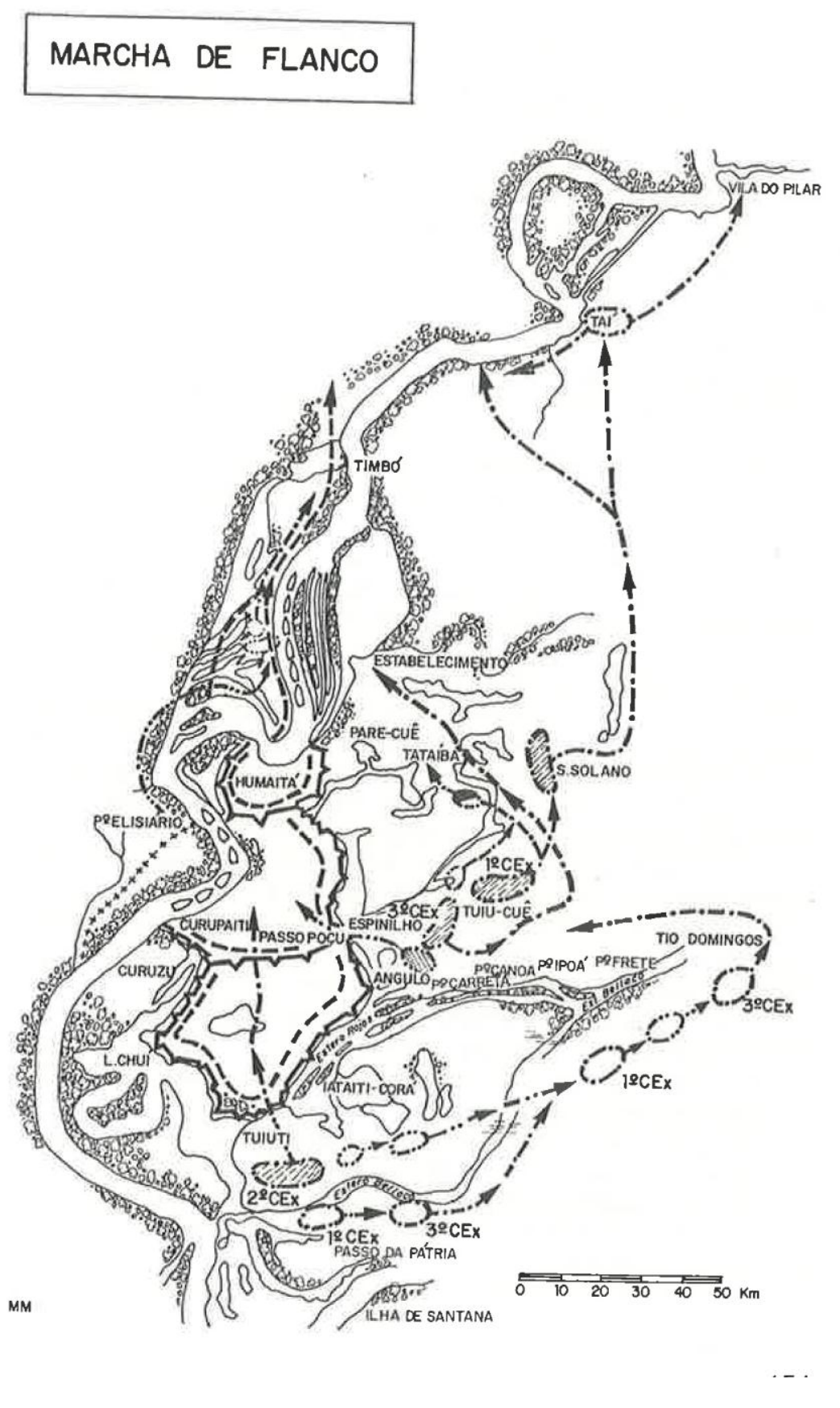

Figura 20 - FERREIRA ALVES 1979: 151. 
Não devemos nos espantar, portanto, ao constatar que, por volta do início da guerra, os extremos da estimativa variassem entre $350 \mathrm{mil}$ e um milhão e meio de habitantes." Em 1795, um recenseamento considerado meticuloso, registrara 97.480 almas, incluindo onze mil “índios de missão'. Duas décadas depois, um tal de Graham - cônsul americano em Buenos Aires - já apontava 300 mil, cifra que, por nova estimativa aparecida em 1825, cai para 200 mil. Em 1839/40, um recenseamento ordenado pelo Dr. Francia e que o autor considera o mais confiável, indica uma população de 220 mil habitantes. A cifra mais exagerada e na qual têm se baseado os inventores do genocídio, é de 1.337.000, de um certo coronel du Graty, que dá ao Paraguai quase a mesma população de toda a Confederação Argentina que, na época, possuía um milhão e meio de habitantes. A conclusão de Burton é de que, considerando o recenseamento de Francia e os índices estimados de natalidade e morte, a população do Paraguai teria duplicado até 1865, cifrando-se então em 450 mil almas, sendo que a população masculina, entre 15 e 55 anos, seria de 110 mil homens, coerente com o efetivo do Exército paraguaio em abril de 1965, citado pelo coronel George Thompson em seu livro sobre a guerra, ou seja 80 mil combatentes. (TORRES, 2006)

Por fim, Burton faz análises das economias da época e já naquele período desmistifica a ideia que o Paraguai era um país industrializado e independente do imperialismo inglês e que faria concorrência aos ingleses no comércio na América do Sul. Como TORRES (2006) apresenta a seguir.

Os dados econômicos são ainda mais reveladores. (...). A agricultura, basicamente de subsistência, ainda usava o arado de madeira. O principal produto de exportação era a erva-mate (monopólio do governo), além do fumo e do algodão, culturas que começaram a ser desenvolvidas no governo de Carlos Lopez. As importações incluíam armamentos, ferragens, secos e molhados e tecidos, principalmente para confecção de fardamentos. Com os recursos amealhados pela severa política de Francia, Carlos Lopez pôde iniciar um programa de desenvolvimento do país, com viés nitidamente belicista. Mandou vir um grande número de técnicos estrangeiros, principalmente ingleses, que lhe permitiram implantar um arsenal de guerra, uma fábrica de armas e de pólvora, uma fundição em lbicui, iniciar a construção de uma ferrovia de Assunção à Vila Rica (108 milhas) e inúmeras estradas carroçáveis. Nos dois anos anteriores à guerra o comércio exterior do Paraguai era de três milhões de libras esterlinas, enquanto a esse 
tempo o comercio exterior do Brasil era superior a 20 milhões de libras. (TORRES, 2006)

Desta forma, temos ainda mais relatos que podem nos dar uma noção do que foi o conflito na Bacia do Prata e como a geografia foi usada para vencer a guerra. Quando usamos o termo Geografia Militar leia-se tamanho da população, distribuição da população, instrução da população, disponibilidade para fabricação de artefatos bélicos (indústria bélica), terreno, teatro de operações, movimentações, estradas, acesso entre outros fatores.

\section{A questão dos Arquivos ultrassecretos: uma breve crítica}

Os debates sobre os arquivos ultrassecretos no congresso nacional (2011) mostram que a liberdade sobre as informações no Brasil ainda é questionável. Os pesquisadores, mesmo nos dias de hoje, não têm acesso total aos arquivos nacionais sobre a Guerra do Paraguai, por exemplo, mais de cento e quarenta anos depois do conflito. Planos de guerra, estratégias, táticas, unidades envolvidas, combates, combatentes, número de feridos e mortos, crimes de guerra, teatro de guerra, armamentos, desenvolvimento tecnológico, todas essas informações não foram fáceis de ser reunidas e, assim mesmo, alguns pesquisadores tiveram a coragem de se debruçar sobre o assunto e mexer em coisas que muitos gostariam que fossem esquecidas.

Recorrer no mesmo erro de Rui Barbosa, que queimou os arquivos de entrada dos escravos no Brasil para passar uma borracha num dado momento da nossa história, trouxe consequências terríveis para os seus descendentes que, por sua vez, resulta em perda de uma busca de suas identidades. Se o acesso a essas informações, documentos confidenciais, for vetado do conhecimento do público, a democracia não estará avançando e até alguns erros políticos do passado podem ocorrer novamente.

Atualmente temos uma legislação arquivista, decreto $\mathrm{n} 04.553$, de 27 de dezembro de 2002. O artigo $1^{\circ}$ diz que "este decreto disciplina a salvaguarda de dados, informações, documentos e materiais sigilosos, bem como das áreas e instalações onde tramitam". 0 artigo $5^{\circ}$ classifica os tipos de documentos, "Os dados ou informações sigilosas serão classificados em 
ultrassecretos, secretos, confidenciais e reservados, em razão do seu teor ou dos seus elementos intrínsecos".

No parágrafo primeiro, vem a definição de arquivo ultrassecreto:

$\S 1$ ㅇ São passíveis de classificação como ultrassecretos, dentre outros, dados ou informações referentes à soberania e à integridade territorial nacionais, a planos e operações militares, às relações internacionais do País, a projetos de pesquisa e desenvolvimento científico e tecnológico de interesse da defesa nacional e a programas econômicos, cujo conhecimento nãoautorizado possa acarretar dano excepcionalmente grave à segurança da sociedade e do Estado.

No parágrafo segundo do artigo $5^{\circ}$, temos a definição de arquivos secretos:

$\S 2^{0}$ São passíveis de classificação como secretos, dentre outros, dados ou informações referentes a sistemas, instalações, programas, projetos, planos ou operações de interesse da defesa nacional, a assuntos diplomáticos e de inteligência e a planos ou detalhes, programas ou instalações estratégicos, cujo conhecimento não autorizado possa acarretar dano grave à segurança da sociedade e do Estado.

No parágrafo terceiro do artigo $5^{\circ}$, por fim, a definição de arquivos confidenciais:

§ 3ำ São passíveis de classificação como confidenciais dados ou informações que, no interesse do Poder Executivo e das partes, devam ser de conhecimento restrito e cuja revelação não autorizada possa frustrar seus objetivos ou acarretar dano à segurança da sociedade e do Estado.

O artigo $7^{\circ}$ estipula o período que cada um dos tipos de arquivos devem permanecer em sigilo:

I - ultrassecreto: máximo de trinta anos; (Redação dada pelo Decreto $n^{\circ}$ 5.301, de 2004) II - secreto: máximo de vinte anos; (Redação dada pelo Decreto no 5.301, de 2004).

III - confidencial: máximo de dez anos; e (Redação dada pelo Decreto no 5.301, de 2004).

IV - reservado: máximo de cinco anos. (Redação dada pelo Decreto no 5.301, de 2004).

Parágrafo único. Os prazos de classificação poderão ser prorrogados uma vez, por igual período, pela autoridade 
responsável pela classificação ou autoridade hierarquicamente superior competente para dispor sobre a matéria. (Redação dada pelo Decreto oㅜ 5.301, de 2004). ${ }^{46}$

Os estudos sobre a Guerra do Paraguai em nossa bibliografia nacional, embora com muitos trabalhos sobre o assunto, deveriam estar preenchidos com uma produção mais ampla; tendo como base um dos episódios mais significantes da história de nossa defesa territorial e da história política da bacia do rio Prata. Quando se pensa em defesa nos dias atuais, não se pode deixar de lado nenhum ponto deste episódio, mesmo que seja necessário trazer à tona determinadas informações e, até mesmo, reascender antigas desavenças, entretanto ignorá-las pode significar falta de preparo para lidar com situações futuras e, até mesmo, para criar novas condições de aliança.

A visão realista da política, neste caso, nos aponta um caminho em que as informações secretas não devem ser colocadas a disposição em hipótese alguma, isso em função da "razão de Estado". Entretanto, o Estado não pode estar acima da nação num regime democrático, sendo que a sociedade pode estar em desacordo com as ações políticas do passado e escolher não as repetir no futuro. Há que se realizar uma elevada discussão nas plenárias legislativas e do supremo tribunal federal para que se definam quais arquivos podem ou não ser visitados, como já estamos fazendo no caso da comissão da verdade entre outros.

Ainda não nos retratamos o suficiente em filmes, quase não se produz histórias cinematográfica sobre esse episódio cheio de dramas e de vida e morte. Desta forma, ainda falta que este episódio esteja na memória coletiva, colocando-o como essencial na construção de nossa identidade nacional.

\footnotetext{
${ }^{46} \mathrm{In}$ : http://www.conarq.arquivonacional.gov.br/cgi/cgilua.exe/sys/start.htm?infoid=145\&sid=54 (acesso em 28/06/2011).
} 


\section{CAPÍTULO 6 - O FIM DO "LONGO" SÉCULO XIX, A GEOGRAFIA MILITAR BRASILEIRA SE APRESENTA: OS SERTÕES DE EUCLIDES DA CUNHA.}

\section{Introdução}

Obra que inaugura o chamado Pré-Modernismo brasileiro (ao lado de "Canaã", de Graça Aranha), "Os Sertões" (1902), de Euclides da Cunha, ultrapassa os limites da arte literária ao percorrer com afinco, entre outros, temas próprios da sociologia, da antropologia e da geografia. Lidando com assuntos tão abrangentes e apresentando alternância de enfoques, fundindo abordagem ensaística e narração literária, o livro é tido por estudiosos como Antônio Candido e Alfredo Bosi como de difícil classificação. Entretanto, a riqueza de sua linguagem, comumente enquadrada como "barroco científico", não deixa dúvida quanto à sua literariedade, tornando-o um dos mais importantes textos do nosso cânone nacional.

Engenheiro militar, bacharelado em Matemática e Ciências Físicas e Naturais, Euclides cursou, de 1890 a 1892, a Escola Superior de Guerra. Nessa função, trabalhou na Estrada de Ferro Central do Brasil, e também como superintendente de obras em São Paulo e engenheiro fiscal na Comissão de Saneamento de Santos (1904). Há que se destacar ainda a sua atuação na imprensa, em especial a colaboração para "O Estado" (1897), cujos comentários escritos sobre a guerra da Canudos (conflito que observou in loco) serviram de base para a composição de "Os Sertões". Designado em 1905 como chefe da Comissão de Reconhecimento do Alto Purus, escreveu obras sobre as questões da fronteira norte brasileira. Em 1909, pouco antes de sua trágica morte, assume a cadeira de lógica no Colégio Pedro II do Rio de Janeiro.

Participou da elaboração da revista do exército "Revista da Família Acadêmica", "na qual os que participaram na sua elaboração, procuram passar o seu inconformismo filosófico-político, dentre eles Cândido Mariano Rondon, Lauro Muller, Tasso Fragoso, Euclides da Cunha, Licínio Cardoso" (RUDZIT, 1997:46). 
Dividido em três partes, "Os Sertões" obedece a uma estrutura determinista, ocupando-se em descrever o meio (o sertão baiano), o homem que habita este meio (o sertanejo) e por fim uma dada ação resultante das implicações deste homem com este meio (a guerra da Canudos).

Em "A Terra" (a primeira parte), o autor debruça-se sobre os principais aspectos da geografia brasileira, detendo-se, sobretudo na apresentação detalhada do sertão nordestino. Sua sólida formação em engenharia militar, que incluiu estudos de Geologia, Botânica e Etnologia, contribuiu para a elaboração dos apontamentos sobre vegetação, relevo, clima e composição do solo da região onde ocorreu a guerra de Canudos, povoado encravado no Vale do rio Vasa-Barris, disposto entre as serras do Cambaio e do Cocorobó, no nordeste baiano. Além da busca pelo rigor científico, vale destacar a poeticidade com que o autor elabora seu texto.

O Planalto Central do Brasil desce, nos litorais do Sul, em escarpas inteiriças, altas e abruptas. Assoberba os mares; e desata-se em chapadões nivelados pelos visos das cordilheiras marítimas, distendidas do Rio Grande a Minas. Mas ao derivar para as terras setentrionais diminui gradualmente de altitude, ao mesmo tempo em que descamba para a costa oriental em andares, ou repetidos socalcos, que o despem da primitiva grandeza afastando-o consideravelmente para o interior.

De sorte que quem o contorna, seguindo para o norte, observa notáveis mudanças de relevos: a principio o traço contínuo e dominante das montanhas, precipitando-o, com destaque saliente, sobre a linha projetante das praias; depois, no segmento de orla marítima entre o Rio de Janeiro e o Espírito Santo, um aparelho litoral revolto, feito da envergadura desarticulada das serras, riçado de cumeadas e corroído de angras, e escancelando-se em baias, repartindo-se em ilhas, e desagregando-se em recifes desnudos, à maneira de escombros do conflito secular que ali se trava entre os mares e a terra [...] (CUNHA,2009:71)

"O homem" (a segunda parte) traça um perfil do sertanejo, e em abordagem mais ampla, promove um levantamento dos traços psicossociológicos do homem brasileiro. É nesta parte da obra que o autor constrói (sob forte influência darwinista, positivista e determinista) a teoria dos "dois Brasis", refletindo sobre as diferenças raciais entre os habitantes do litoral e os sertanejos. Como decorrência desta interpretação, Euclides da Cunha 
produziu aquela que se tornaria a frase mais popular advinda da obra: "O sertanejo é, antes de tudo, um forte".

"A luta" (terceira e última parte) ocupa-se em narrar, com contornos épicos, os embates entre as tropas oficiais e os seguidores de Antônio Conselheiro.

\section{“Os Sertões”, obra prima da Geografia Militar brasileira.}

Não é intenção, da presente pesquisa, classificar a obra de Euclides da Cunha, tarefa que, como afirma o Alfredo Bosi, é uma tarefa monstruosa, talvez beire ao infinito. Não pode ser possível esgotar "Os Sertões" sobre nenhuma análise, mas é bem possível explorá-lo sobre muitos aspectos. Por isso, adiantando, as devidas controvérsias, reivindico a obra sobre o olhar da Geografia Militar, acreditando ser adequado classifica-la como tal, pois possui forte influência de Humboldt, com extensos trabalhos em geologia, geomorfologia, clima, geografia social entre outros.

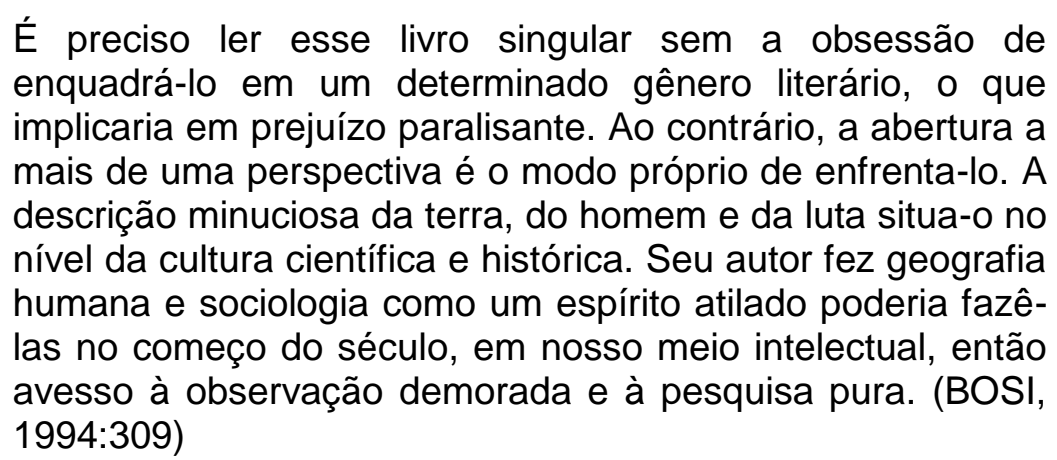

A estrutura do trabalho apresenta um caminho do método geográfico, a relação entre a sociedade e o meio. Primeiro, "A Terra", depois o "O Homem", e então "A luta", a relação do homem e do espaço sobre a ótica do fenômeno bélico. A terceira parte apresenta descrições de movimentação: armas, tipo de forças, tamanho dos efetivos e ação tática no teatro de operações da Guerra, portanto pode ser analisado sobre a ótica da Geografia Militar.

Com Humboldt, sempre venerado por Euclides, o problema não é tão diferente. O escritor brasileiro retorna ao tema da invasão das águas, agora do Atlântico sobre o norte da África, num cataclismo diluvial de proporções bíblicas. E o naturalista alemão, que nunca pisou no Brasil, verá sua 
"hipótese brilhante" ser aproveitada para o desenvolvimento de uma teoria sobre a formação dos desertos em latitudes onde também o solo, num passado remoto, tinha podido ser fértil e exuberante. Registrem-se ainda, apenas como parênteses, três lugares em Os Sertões em que as ideias de Humboldt, claramente glosadas na Caderneta, fundiram-se com a escritura euclidiana (pp. 108, 114,128). (BERNUCCI, 2009:25) ${ }^{47}$

Euclides da Cunha traz a influência da escola da geografia alemã determinista, bem condizente com os movimentos ligados as forças armadas da época, que estavam revendo a influência franco-inglesa que tinham nossas forças armadas, apontavam para via prussiana de modernização, alguns anos mais tarde surgiriam os "jovens turcos" (vide capítulo 7) que irão propagar a via alemã como o caminho mais apropriado para a modernização das forças armadas. A geografia alemã apontava um caminho científico para geografia humana e, naquele momento, a discussão sobre a influência do meio sobre a sociedade eram pautas do dia.

"Os Sertões" é, também, fruto de sua formação na Escola Militar e da Escola Politécnica do Rio de Janeiro. Lá, ele teve todo o programa de formação de oficiais da Escola Militar (vide capítulo 7). "Talvez esta prática se deva ao hábito no manejo de vocábulos pertencentes às matérias estudadas por Euclides nos anos de Escola Militar e da Escola Politécnica do Rio de Janeiro". (BERNUCCI, 2009:33). Assim, ele absorveu todas as modernizações do ensino militar, desde 1874 (vide capitulo 7), quando a disciplina Geografia reaparece no programa curricular.

Euclides teria estudado, no primeiro ano: Álgebra Superior, Geometria Analítica, Cálculo Diferencial e Integral, Física Experimental, Química Inorgânica, Desenho Topográfico (Teórica e Prática); no segundo ano: Tática, Estratégia, História Militar, Direito Internacional, Direito Público, Direito Militar, Geometria Descritiva e Planos Cotados. Na Escola Politécnica fez provas de adaptação em Zoologia, Botânica, Mineralogia e Física e frequentou cursos de Engenharia Civil. José Carlos Barreto conjetura que Euclides tenha feito exames de Mineralogia e Geologia também na mesma instituição. Ao ser readmitido na Escola Militar (atual Escola Superior de Guerra) em 1890, depois do seu desligamento em dezembro de 1888, submeteu-se a exames complementares de Física, Química, Cálculo e a exames de

${ }^{47}$ Prefácio, In: "Os Sertões", Euclides da Cunha, (2009), São Paulo. Ateliê Editorial. 
todas as matérias do segundo ano da Escola (Mecânica, Balística, Artilharia, Aplicação da Eletricidade à Guerra, Desenho de Fortificações e Máquinas, Trigonometria Esférica, Astronomia, Geodésia, Mineralogia, Geologia, Desenho de Cartas Geográficas, Alemão). (BERNUCCI, 2009:33)

Euclides e sua obra contexto em que, no Brasil, havia a necessidade de uma obra que desse conta de uma descrição geográfica mais profunda. Esta obra foi o contato mais próximo dos grandes vazios demográficos que algum brasileiro morador dos grandes centros da época iria chegar. É um impacto que só décadas mais tarde iria ser constatado pelos movimentos tenentistas da coluna Prestes. É a teoria dos dois países, de um lado um país que tinha acesso a alguns parcos produtos da civilização moderna, do outro um país esquecido por todos, em "Uma Ficção Geográfica" (op.cit, 2009:677). Euclides debate o cerne da questão pela geografia.
A linha férrea corre no lado oposto. Aquele liame do progresso passa, porém, por ali, inútil, sem atenuar sequer o caráter genuinamente roceiro do arraial. Salta-se do trem; transpõem-se poucas centenas de metros entre casas deprimidas; e topa-se para logo, à fimbria da praça - o sertão...
Está-se no ponto de tangência de duas sociedades, de todo alheias uma à outra. O vaqueiro encourado emerge da caatinga, rompe entre a casaria desgraciosa, e estaca o campeão junto aos trilhos, em que passam, vertiginosamente, os patrícios do litoral, que o não conhece.

Assim, nesta questão, temos alguns movimentos que irão revelar os dois Brasis para o seu conhecimento específico: A Guerra do Paraguai (Vide a Retirada de Laguna), A Guerra de Canudos (1896), a Coluna Prestes (1925). Desta forma, se dá o reconhecimento desta dura dualidade brasileira, em batalhas e insurreições. Em todas, o conhecimento do espaço geográfico se revelou esplendorosamente, sendo vertedouros de conhecimento geográfico e cartográfico. BERNUCCI (2009:39) ressalta a importância de "Os Sertões" a linguagem militar e arquitetônica:

Duas linguagens em Os Sertões merecem ser estudas, a militar e a arquitetônica. Na verdade, elas estão às vezes relacionadas e compartilham um espaço comum que grosseiramente poderíamos denominar 0 da engenharia 
militar, sem que com isso se limite o termo às atividades dos sapadores e pontoneiros.

Para Euclides da Cunha, o meio geográfico é um elemento ponderador fundamental na guerra. Através de suas análises sobre o meio, 0 autor verificará como esse irá determinar as questões tática tanto da ofensiva, quanto da defensiva. Entretanto, para Euclides, o conhecimento do guerrilheiro sobre o terreno é decisivo. O autor compara o jagunço brasileiro a um guerrilheiro-tugue, conhecedor das dificuldades do terreno, dotados de uma grande mobilidade e estabelecendo tocais, armadilhas, fustigando o inimigo pelos flancos, capturando armas do inimigo e ganhando moral. Em "A Guerra das Caatingas" (op.cit, 2009:356), apresenta o debate da guerra convenciona e da guerra de guerrilha e sobre como meio pode ser decisivo para ambos os lados, uma clássica discussão no campo da Geografia Militar.

Os doutores na arte de matar que hoje, na Europa, invadem escandalosamente a ciência, perturbando-Ihe o remanso com um retinir de esporas insolentes - e formulam leis para guerra, pondo em equação as batalhas, têm definido bem o papel das florestas como agente tático precioso, de ofensiva ou defensiva. (...).

Porque estas, malgrado a sua importância para defesa do território - orlando as fronteiras e quebrando o embate às invasões, impedindo mobilizações rápidas e impossibilitando a translação das artilharias. Podem favorecer, indiferentemente os dois beligerantes. (...). São uma variável nas fórmulas do problema tenebroso da guerra, capaz dos mais opostos valores.

Ao passo que as caatingas são um aliado incorruptível do sertanejo em revolta. Entram também de certo modo na luta. Armam-se para o combate; agridem. Trançam-se, impenetráveis, ante o forasteiro, mas abrem-se em trilhas multívias, para o matuto que ali nasceu e cresceu.

O jagunço faz-se o guerrilheiro-tugue, intangível... (op.cit, 2009: 356-357)

A parte "A Luta", segundo BOSI (1994: 309), narra relações entre os movimentos das forças que necessariamente devem passar pelo olhar crítico da geografia, da sociologia e da história, tendo uma discussão que para geografia não pode ser simplesmente esquecida.

À longa narração das escaramuças (Parte III - A Luta), quis Euclides dar uma introdução objetiva sobre o meio e sobre o 
homem do sertão. Os reparos científicos que se fizeram e que ainda se possam fazer a essas partes propedêutica competem obviamente ao geógrafo, ao etnólogo e ao sociólogo; a nós cabe apenas verificar o quanto subjetivo, de euclidiano, se infiltrou nessa páginas de intenção analítica.

Um debate que é feito por Euclides aparece em todo presente trabalho: o do papel da geografia na guerra assimétrica. A defesa estratégica e o uso do conhecimento do campo de batalha como um elemento de combate. O autor de "Os Sertões" constrói muitos parágrafos descrevendo a ação da guerra de guerrilha dos sertanejos. E a ineficiência de qualquer que fosse a tradição da guerra convencional. O terreno da caatinga mais a guerrilha do jagunço iriam ser obstáculos muito pesados para o desorientado exército nacional, que não sabia que caminho teórico deveria seguir (se alemão ou francês), que ainda não tinha criado o formador próprio de sua maneira de fazer a guerra, de forma diferente se mostrava o sertanejo que havia desenvolvido a sua própria maneira de combater, uma maneira mais adaptada ao seu meio.

Entre a incoercível tática prussiana, em que é tudo a precisão mecânica da bala, e a nervosa tática latina, em que tudo é o arrojo cavalheiresco da espada, tínhamos a esgrima perigosa com os guerrilheiros esquivos cuja força estava na própria fraqueza, na fuga sistemática, num vaivém doidejante de arrancadas e recuos, dispersos, escapantes do seio da natureza protetora. (op.cit, 2009: 383)

O último choque, que ficou conhecido como " $4^{\circ}$ fogo" trouxe para o campo de batalha alguns novos armamentos, o mais conhecido desses foi a "matadeira" (Whitworth 32), peça de artilharia de alta precisão e impacto - onze delas foram usadas no confronto. Enquanto a força nacional usava rifles raiados, a maioria dos armamentos dos jagunços de Antônio Conselheiro ainda usavam armas tipo pederneira de raia lisa, carregada pela boca. Essa última batalha de Canudos não foi uma operação precipitada, como as outras. Para esta, mediu-se cada palmo do terreno e realizou-se um plano de operações do teatro da guerra, conforme descreve Euclides. É claro que para a visão euclidiana da guerra do Canudos era possível evitar o massacre desde que as ações fossem medidas e bem coordenadas. Acontece que a força nacional tinha a intenção de dispersar Canudos e acabar com a ocupação: assim, a 
coordenação do ataque usava artilharia bombardeando 0 centro do povoamento e o cerco por duas colunas nos flancos mais frágeis.

$\mathrm{O}$ ataque por dois pontos, pelo caminho de Jeremoabo e pela extrema esquerda, derivando pelos contrafortes da Fazenda Velha, enquanto a artilharia, sem deixar a sua posição, agisse, bombardeando pelo centro, surgia, entretanto, como único plano - impetuoso e intuitivo - à mais ligeira observação do teatro de luta. Não se cogitou, porém, de observar o teatro de luta. O plano firmado era mais simples. As duas colunas combatentes, após uma marcha de flanco de quase dois quilômetros para a direita do acampamento, que se preestabeleceu realizada sem que a perturbasse 0 inimigo, obliquariam à esquerda demandando o Vaza-Barris. Dali volvendo ainda à esquerda, arremeteriam em cheio até à praça das igrejas. $O$ movimento, contornante a princípio, ultimar-se-ia em trajetória retilínea; e se fosse impulsionado com sucesso favorável, os jagunços, mesmo no caso de inteiro desbarate, teriam, francos ao recuo, três ângulos do quadrante. Poderiam, a salvo, deslocar-se para as posições inacessíveis do Caipã, ou qualquer outra de onde renovassem a resistência. (op.cit, 2009:598)

Alinhando sua crítica à modernização das forças nacionais, Euclides da Cunha irá realizar uma série de comentários contra o movimento das linhas no teatro de operações do campo de batalha. Suas críticas são duras e mostram como as forças armadas terrestres careciam ainda de uma formação mais ampla, e de acordo com as transformações tecnológicas, não era suficiente termos armamentos mais moderno e experimentá-lo a revelia na questão de Canudos. O resultado poderia ter sido outro e o massacre poderia ter sido evitado de qualquer forma, sendo fanáticos ou não. Sustentando esse ponto, o autor nota uma série de confusões que aumentaram as baixas de ambos os lados, sendo muito pior para os moradores do povoado. De acordo com BOSI (1994:310), a crítica radical de Euclides da Cunha o colocaria em 1940 no campo dos intelectuais de esquerda, clamando as questões sociais de um Brasil que era desconhecido dos brasileiros.

Tudo indica que tanto Euclides como Nabuco, se fosse homens de trinta anos diante dos problemas de hoje e no Brasil dos nossos dias [1944], estariam entre os escritores chamados indistintamente "da esquerda", embora nenhum deles fosse por temperamento ou por cultura inclinado àquela socialização da vida ou àquela internacionalização de valores que importassem em sacrifício da personalidade 
humana ou do caráter brasileiro. (FREYRE, apud BOSI, 1994:311)

Suas críticas são direcionadas também ao campo das operações de combate, não sendo apenas um especialista militar. Indo para além dos campos da investigação militar, Euclides reforça a visão sociológica e já inclui os fatores psicossomáticos da guerra.

\begin{abstract}
Mas este movimento geral da tropa, como era de prever, foi malfeito. Sobre ser uma manobra sob o olhar do adversário, impropriava-a o terreno. Faltava-Ihe a base física essencial a tática. A linha ideada, feita por um rápido desdobramento de brigadas numa longura de dois quilômetros, ia partir-se em planos verticais, segundo as cotas máximas de cerros e o fundo das baixadas; e desde que não podia traçar-se com celeridade tal que tornasse o mais possível passageira uma situação de desequilíbrio e fraqueza, forçadamente assumida por todas as unidades combatentes, no se desarticularem e darem o flanco ao inimigo até nova posição de combate - era impraticável. (op.cit, 2009:606)
\end{abstract}

Euclides da Cunha realiza uma série de estudos dos recontros das ações das colunas, do cerco, dos bombardeios, dos movimentos das tropas, das tocaias, do uso do meio pelas forças, da diferença da ação de Moreira Cesar e da quarta expedição. Suas duras críticas ao Marechal Carlos Machado Bittencourt, que havia estado de forma destacada na batalha de Tuiuti (1866), e ao General Artur Oscar, aos quais responsabiliza pelo grande massacre que foi Canudos. Uma crítica radical é o fio condutor de "Os Sertões": dentro desta existem elementos sociológicos, geográficos, etnológico e da geografia do teatro de operações de guerra e o pano de fundo para tudo isso, uma grande crítica a nossa organização militar.

Termino a análise geográfica de "Os Sertões" (2009: 66) com as próprias palavras de Euclides da Cunha sobre o massacre da Guerra de Canudos, que matou quase 30 mil pessoas.

A campanha de Canudos tem por isto a significação inegável de um primeiro assalto, uma luta talvez longa. Nem enfraquece o asserto o têrmo-la realizado nós, filhos do mesmo solo, porque etnologicamente indefinidos, sem tradições nacionais uniformes, vivendo parasitariamente à beira do Atlântico dos princípios civilizadores elaborados na Europa, e armados pela indústria alemã - tivemos na ação um papel singular de mercenários inconscientes. Além disto, mal unidos àqueles extraordinários patrícios pelo solo em 
parte desconhecido, deles de todo nos separa uma coordenada histórica - o tempo.

Aquela campanha lembra um refluxo para o passado.

E foi, na significação integral da palavra, um crime.

Denunciemo-lo.

A discussão, de que tanto falamos, da desmilitarização da Força Pública já está esboçada nos escritos de Euclides da Cunha, todos aqueles que querem se debruçar sobre o tema, devem ter "Os Sertões" como leitura obrigatória e como livro de cabeceira. Este clássico apresenta a origem dos problemas que estavam relacionados as forças públicas que algumas décadas depois se tornariam as polícias militares estaduais. 


\section{CAPÍTULO 7 - GENERAL PAULA CIDADE: DA "SUA" GEOGRAFIA MILITAR E DO SEU "ESQUECIMENTO".}

\section{Introdução}

O ensino de Geografia no exército brasileiro aparece após a guerra do Paraguai, quando "a Escola Central do Largo de São Francisco deixa de ser subordinada ao Ministério da Guerra, passando para o Ministério do Império, com a nova denominação de Escola Politécnica" (RUDZIT,1997:40). Segundo RUDZIT (1996:40), a ideia do Visconde do Rio Branco, responsável pelo plano de transformação do ensino militar no Brasil, era criar para o exército brasileiro os experts militares, portanto, "o que se tenta com a reforma política de 1874 é homogeneizar a formação de seus oficiais, ou seja, procurase dar um ensino aos futuros oficiais somente em bases militares" (Ibidem).

No currículo da Escola da Praia Vermelha já aparece o ensino de geografia, como é destacado a seguir em MOTTA (1976) apud RUDZIT (1997: 41-42):

\section{$\underline{\text { Curso Preparatório }}$}

$1^{\circ}$ Ano: Gramática Nacional, Geografia, Francês, Aritmética e Desenho Linear.

$2^{\circ}$ Ano: Língua vernácula, Francês, Inglês, História antiga, Álgebra e Desenho Linear.

$3^{\circ}$ Ano: Língua vernácula, Inglês, História (Idade Média, Moderna, Contemporânea e Pátria), Geometria e Trigonometria plana, Desenho Linear e Geometria prática.

\section{$\underline{\text { Curso de Infantaria e Cavalaria }}$}

\section{$1^{\circ}$ Ano:}

1a cadeira: Álgebra Superior, Geometria Analítica, Cálculo Diferencial e Integral. 
2a cadeira: Física experimental, compreendendo elementos de telegrafia elétrica militar; Química inorgânica; aula: Desenho Topográfico, Topografia e reconhecimento do terreno.

$2^{\circ}$ Ano:

1 a cadeira: Tática, Estratégia, História Militar, Castração, Fortificação passageira e permanente, compreendendo o ataque e defesa dos entrincheiramentos e das praças de guerra, e noções elementares de Balística.

2a cadeira: Direito Internacional aplicado às relações de guerra, noções de Direito Natural e Direito Público, Direito Militar, análise da Constituição do Império; aula: Geometria descritiva, planos cotados e sua aplicação ao desenfiamento das fortificações militares.

Curso de Artilharia

$1^{\circ}$ e $2^{\circ}$ anos: como os da Infantaria e Cavalaria.

\section{$3^{\circ}$ ano:}

1a cadeira: Mecânica Racional e sua aplicação às máquinas, Balística;

$2^{a}$ cadeira: Tecnologia Militar, compreendendo o desenvolvimento da telegrafia e iluminação elétrica da defesa das praças, noções de Mineralogia, Geologia e Botânica, Artilharia e Minas Militares; aula: Desenho de fortificação e das máquinas de guerra.

\section{$\underline{\text { Curso do Estado-Maior }}$}

$1^{\circ}, 2^{\circ}$ e $3^{\circ}$ anos: como da Artilharia.

\section{$4^{\circ}$ ano:}

1a cadeira: Trigonometria Esférica, Ótica, Astronomia, Geodésia; 2a cadeia: Administração militar, noções de Economia e Política, e de Direito Administrativo; aula Desenho geográfico, redução de cartas.

\section{Curso de Engenharia Militar}


$1^{\circ}, 2^{\circ}, 3^{\circ}, 4^{\circ}$ anos: como o Curso de Estado-Maior;

\section{$5^{\circ}$ ano:}

1a cadeira: Construções civis e militares, Hidráulica, Estradas ordinárias e vias férreas, principalmente em relação à arte da guerra;

2a cadeira: Química Orgânica, Mineralogia, Geologia e Botânica; aula: noções de Arquitetura Civil e Militar, desenho de arquitetura, execução de projetos.

RUDZIT (1997:42) afirma ressaltando o aparecimento da Geografia como matéria na formação dos oficiais brasileiros. "A primeira mudança visível neste currículo, é o aparecimento da Geografia como matéria, mas somente do Curso Preparatório" (Ibidem). É importante perceber que existem disciplinas que estão correlacionadas com o campo da Geografia como: "no curso de Infantaria e Cavalaria, Desenho Topográfico, Topografia e reconhecimento do terreno, além de Direito Natural, que se pode correlacionar com temas da Geografia Humana" (ibidem). Para o curso de Estado-Maior estão relacionados temas que tem a ver com disciplinas que são importantes para construir uma visão política do espaço geográfico como Economia Política, por exemplo. "Já para o Curso de Estado-Maior, vale destacar dois pontos: a aula de desenho geográfico que pode ser correlacionada ao atual curso de Cartografia" (ibidem).

A modernização do currículo do ensino de oficiais de 1874 tinha como objetivo responder a organização militar da argentina, que apresentava melhor equipamento e capital humano que o exército imperial, entretanto o resultado não foi o esperado e o nosso exército carecia de modernização ainda no início do século XX, quando irá contratar a Missão Militar Francesa para resolver um problema que durante muitos anos fora intitulado como a "Questão Militar". Em 1887 cria-se o último movimento de modernização do exército imperial criando O Imperial Colégio Militar do Rio de Janeiro.

Permanece o curso preparatório da praia Vermelha, sendo que a escola é desmembrada em duas (Escola Militar do Rio Grande do Sul e Escola Superior de Guerra), e vem a tona a discussão sobre qual caráter a instituição 
militar deveria ter como comenta O Coronel Davi Ribeiro Sena na revista "A Defesa Nacional" (1986:127).

Em 1896, iniciava-se nova etapa na evolução da instituição militar: a criação do Estado-Maior do Exército, em substituição à Ajudância-Geral. Sem ter definido, com exatidão, as suas tarefas, o novel organismo direcional, contudo, já se firmava em diretrizes essenciais ao seu funcionamento, (...): a) prover a organização do Exército e planejar e coordenar os exercícios militares; b) organizar os planos gerais de defesa, de distribuição dos efetivos, da ordem de batalha, de mobilização e de transporte; c) propor os meios necessários à consecução da instrução e à manutenção da disciplina na tropa. (MOTTA, 1976 apud RUDIZIT, 1997:43)

Em 1920, a Missão Militar Francesa construiu a Escola do EstadoMaior, que irá ser o centro de oficiais ligado ao Estado-Maior, portanto referência de ensino e de relevância política para as forças terrestres do exército nacional.

Com essa mesma designação já existia uma escola entre nós, tendo por fim habilitar os Oficiais, "até o posto de Capitão", para o Serviço de Estado-Maior. Essa escola criada em fins de 1905, só começou a funcionar em 1907. A princípio no Quartel-General, foi para o quartel da então extinta Escola Militar, na Praia Vermelha, onde funcionou em fins de 1907 e em 1910, tendo também, por pouco tempo, existido no Edifício sede da Direção Geral de Saúde, existente na Praça da República. Voltando ao QG, deixou de funcionar em 1918.

\section{$(\ldots)$}

A nova escola de Estado-Maior brasileira foi aberta em solene cerimônia no dia 7 de abril de 1920, nas sua instalações provisórias, especialmente adaptadas, numa ala do Quartel-general, à Praça da República. (MALAN,1988:9899)

Do final do século $X I X$, até as primeiras décadas do século $X X$ a discussão sobre o processo de modernização das forças do Brasil irá ser polarizados pelo debate: missão militar alemã versus missão militar francesa; e no centro das questões está a geografia. 


\section{General Paula Cidade: e a "sua" Geografia Militar}

No início do século XX, a "Questão Militar" ainda era o grande debate nos altos escalões da organização do Estado-Maior. Qual o caráter do processo de modernização. Muito influenciado pela guerra Franco-Prussiana que deixava uma lição a cerca da geografia na formação dos oficiais do exército, o modelo prussiano ganhava importantes adeptos, enquanto outra parte do nosso exército era favorável a missão francesa. "A corrente próAlemanha encontrava seus mais importantes adeptos no Barão de Rio Branco, nos estagiários do Exército alemão e no Marechal Hermes da Fonseca" (MALAN, 1988:39).

O então Coronel Paula Cidade foi enviado durante o governo do marechal Hemes da Fonseca (em 1910), junto com outros oficiais brasileiros, para estagiar no Exército da Prússia. Esse grupo de pensadores militares são os fundadores da revista "Defesa Nacional" e foram denominados, mais tarde, de "jovens turcos", com afirma MARTIN (2007), a seguir.

Pois uma das primeiras decisões do Marechal-presidente foi
justamente enviar uma missão à Alemanha, em 1910, com
vistas a estes oficiais absorvem os ensinamentos desta
nova matriz da modernização bélica, já em plenos
preparativos para guerra mundial. Ao retornarem ao Brasil,
estes oficiais serão apelidados de "os Jovens Turcos", numa
alusão irônica à sua admiração pelos revolucionários
comandados por Kemal Aturk, que agitavam aquele país
muçulmano. (MARTIN, 2007: 102)

Ao retornar Paula Cidade ajuda a fundar a revista "A Defesa Nacional"48, juntamente com Bertoldo Klinger, Leitão de Carvalho, Parga Rodrigues, Brasílio Taborda e Jorge Pinheiro, e funda a Biblioteca do Exército.

Segundo Odylio Denys, o regresso dos oficiais que estagiaram na Alemanha em 1912 serviu para dar maior

\footnotetext{
${ }^{48}$ RODRIGUES (2007): Com relação às publicações, o espaço principal foi o Boletim do Estado Maior doExército e a Revista A Defesa Nacional, revista de assuntos militares fundada em 1913, pelos seguintes militares: Estevão Leitão de Carvalho, Jorge Pinheiro, Joaquim de Souza Reis,Bertholdo Klinger, Amaro de Azambuja Villa Nova, Epaminondas de Lima e Silva, César Augusto Parga Rodrigues, Euclides Figueiredo, José Pompêo Cavalcanti de Albuquerque, Mário Clementino de Carvalho, Brasilio Taborda, e, Francisco de Paula Cidade, ou seja, dos doze membros, apenas os quatros últimos não eram ex-estagiários no Exército Alemão, mas sim, adeptos da nova campanha de renovação do Exército. Os redatores iniciais da revista foram os Primeiro Tenentes: Bertholdo Klinger, Estevão Leitão de Carvalho e Joaquim de Souza Reis.
} 
intensidade à nova orientação profissional no Exército. Foram eles os elementos que lançaram a campanha renovadora da Instituição. Para tanto, fundaram a Revista $A$ Defesa Nacional e foram distribuídos conforme solicitação ao Ministro da Guerra, General-de-Divisão Vespasiano Gonçalves de Albuquerque e Silva (30 de maio de 1912 a 15 de novembro de 1914), pelos Corpos de Tropa das suas respectivas Armas, recebendo em um primeiro momento por parte de oficiais mais antigos a denominação de "Jovens Turcos", como maneira de depreciar esses militares e suas ações dita renovadora. De apelido pejorativo no início, terminou com o tempo servindo de símbolo de uma causa. A nova geração de oficiais brasileiros formados a partir do Regulamento das Escolas Militares de 1905, com ênfase na prática, iria aderir com entusiasmo aos novos conhecimentos trazidos pelos oficiais ex-estagiários na Alemanha. (RODRIGUES, 2007)

Com a eclosão da primeira Guerra Mundial, e com a vitória dos aliados, "A Defesa Nacional", que sempre tivera uma visão de modernização pela via prussiana (alemã), começa a mudar a visão de uma missão militar alemã para francesa.

E Paula Cidade, em seu livro "História da Literatura Militar Brasileira", inicia o capítulo V: "Da Missão Militar Francesa aos nossos dias", dizendo: "A campanha tormentosa de "A Defesa Nacional", de certo modo, prepara o terreno para a modernização do Exército através de uma missão instrutora estrangeira". No entanto, o contrato de uma missão militar francesa constitui uma surpresa. A própria "A Defesa Nacional" batera-se por uma Missão alemã, o que, após o Tratado de Versalhes, era impossível. (MALAN, 1988:41)

É nesse contexto, influenciado pela discussão da modernização do exército nacional, que o então Coronel Paula Cidade irá escrever o principal compêndio específico sobre Geografia Militar, intitulado "Notas de Geografia Militar Sul-americana". Na carta ao leitor, o autêntico geógrafo militar brasileiro traz uma série de noções metodológicas a cerca dos estudos de geografia no teatro de operações de guerra, com uma forte presença da influência da Geografia Militar francesa lavalleiana (vide Theóphile Lavallée). "Durante a fase de estudos que se seguiu às guerras de Napoleão, começou a geografia militar a emancipar-se da história, porém, no domínio das incertezas, por falta de critério científico" (PAULA CIDADE, 1940:03). O geografo militar brasileiro pontua a origem da geografia militar estabelecendo um forte laço com a escola 
francesa lavalleiana, apontando que está evoluiu juntamente com a geografia geral.

Com a evolução da geografia geral, entrecortada como foi de acidentes de caráter científico, desenvolveu-se nas mesmas condições a geografia militar. Com o surto da chamada teoria hidrográfica, os trabalhos realizados nas escolas militares francesas versaram antes de tudo sobre as formas dos terrenos, (PAULA CIDADE, 1940: 03)

Mesmo admitindo a influência francesa na concepção das análises geográfica, PAULA CIDADE (1940:04) afirma que as geografias: militar e geral terão um papel relevante na história do pensamento militar a partir de 1870, quando ocorreu a guerra Franco-Prussiana. Sendo que a discussão a cerca da influência do uso da geografia na guerra favoreceu o esforço de guerra prussiano.

Depois de 1870, como consequência das diretrizes científicas adotadas pela geografia geral, inicia-se um novo ciclo para geografia militar, com aparecimento de trabalhos notáveis em quase todos os exércitos europeus, embora "não isentos dos defeitos inerentes aos primeiros produtos de uma transformação". Verifica-se a difusão dos métodos geológicos nos estudos militares do terreno, do mesmo modo por que se vão difundindo no campo da geografia geral. (PAULA CIDADE, 1940:03)

O autor de "Notas de Geografia Militar" ressalta a importância da geografia para entender as narrativas militares e os movimentos condicionados pelo espaço e qual operação resulta no melhor uso das condições do terreno.

Para fazer compreender suas narrativas, ou para explicar este ou aquele sucesso militar, os historiadores antigos já recorriam à descrição do teatro de operações. Admitida a suficiência dos elementos geográficos para explicar a maneira que se desenvolvem as operações de guerra, é natural que se procure, pelo estudo prévio das grandes linhas do terreno, determinar o possível aspecto da luta, em função das condições geográfica diversas. (PAULA CIDADE, 1940: 03)

Quando PAULA CIDADE (1940: 04) diz que a geografia militar vai ocupar-se do papel desempenhado pelos elementos geográficos nas operações de guerra, papel essencialmente variável com as condições de luta, com a sua intensidade, com a direção geral das operações; esse conceito vai 
além das determinações geográficas advindas da escola alemã, ele posiciona o espaço geográfico nas análises das relações militares como um ponderador, sendo o meio, uma verdadeira fonte de possibilidades. Neste conceito existe um embrião de uma das aplicações da geografia com fins militares específicos, portanto revela a geografia militar como instrumento usado para fins bélicos.

Em sua análise da posição do Brasil em relação às questões da geografia militar, PAULA CIDADE (1940) aponta a questão de escala nas análises da geografia militar e apresenta a necessidade que seus estudos têm de não se limitar apenas nos estudos do teatro de operações da guerra, um país com as dimensões do Brasil pode apresentar uma grande gama de cenários.

Seria pueril considerar um território como o do Brasil nas mesmas condições de um campo de batalha ou mesmo de um teatro único de operações, posto que tanto a vastidão do território como a brutalidade dos acidentes geográficos hão de fazer com que os acontecimentos militares, verificados em pontos afastados, se isolem em seus efeitos, pelo menos no campo operativo. (PAULA CIDADE, 1940: 315)

As grandes necessidades geográficas do vasto espaço brasileiro apresentam um desafio muito maior do que entender o campo de operações militares, com advento da Missão militar francesa no Brasil, a noção de Poder Nacional é fortemente vinculada na formação dos oficiais brasileiros e a Geopolítica daria uma resposta mais acertada em relação a escala de análise da Geografia Militar. Essa relação entre as dimensões territoriais do Brasil e o estudo de geografia militar aparece pela primeira vez - na direção construída pela presente tese - na tese de livre-docência de MARTIN (2007) intitulada "Brasil, uma nação geopolítica". A geografia militar não será esquecida de fato, não se pode chegar a uma conclusão mais inverossímil de um estudo como o nosso, a nossa avaliação sobre tal questão advém da necessidade que é imposta pelas dimensões territoriais do Brasil que o transformam numa nação geopolítica e elevam o estudo de geografia na formação política das forças armadas. É uma questão, ao mesmo tempo, de necessidade e de interesse. Não é atoa que o desdobramento desse interesse militar pela geopolítica não foi apenas teórico, mas significou, mais tarde, a disputa pelo poder nacional. 
A questão do poder marítimo como chave para o poder nacional aparece de maneira significativa em "Notas de Geografia Militar", esboçando a grande questão do Poder Nacional, não só a costa brasileira é a porta de entrada do Brasil para as potências externas, como internamente, principalmente na bacia do Amazonas, também é o caminho para dominar todo o território nacional; as condições de repulsas externas dentro do continente pedem outros aparatos e ações, "a posição geográfico-militar do Brasil não põe a coberto de possíveis agressões, quer de seus vizinhos quer de países alémmar. As condições de repulsa não podem ser as mesmas nos dois casos" (PAULA CIDADE, 1940:318). Para superar está questão, o geógrafo militar brasileiro conceitua o conceito de região geográfico-militar.

uma região geográfico-militar pode ser definida como sendo a parte do território em que o exercício pessoal do comando não é embaraçado pelos elementos geográficos.

Em 1934, ano da publicação da primeira edição de "Notas de Geografia Militar", o Gen. Góes Monteiro ${ }^{49}$ resgata as análises da geografia

\footnotetext{
${ }^{49}$ IN: http://cpdoc.fgv.br/producao/dossies/Fatos/magens/biografias/goes monteiro. (acessado 22/03/2011). Com sua formação na Escola de Comando Estado Maior do Exército, articulou o movimento de tenentes que resultou nos levantes conhecidos como tenentismo. Em 1930, assumiu o comando militar do movimento revolucionário articulado para depor o presidente Washington Luís, já que Luís Carlos Prestes havia recusado o convite que the fora feito nesse sentido pelos líderes da conspiração, Getúlio Vargas à frente. Em maio de 1935, deixou o ministério, mas continuou exercendo grande influência no governo. Dele partiu a proposta de fechamento da Aliança Nacional Libertadora (ANL), frente política que reunia diversos setores de esquerda no combate ao fascismo e ao imperialismo. A seguir, mesmo sem ocupar qualquer cargo formal no governo, passou a ser um dos elementos centrais no processo de fechamento do regime, que teve seu desfecho no golpe que instalou a ditadura do Estado Novo, em novembro de 1937. Nos meses anteriores, havia assumido a presidência do Clube Militar, em janeiro, e o comando do Estado-Maior do Exército (EME), em julho. Em 1939, foi enviado aos EUA em missão militar, que objetivava promover uma maior integração entre os dois países no momento em que se iniciava a Segunda Guerra Mundial. Essa aproximação, realizada de maneira lenta mas sistemática, resultou na declaração de guerra do Brasil às potências do Eixo, em 1942, e no envio de tropas brasileiras à Itália, em julho de 1944. Em dezembro de 1943, afastou-se da chefia do EME. Em agosto de 1945, reassumiu o Ministério da Guerra e, nos meses seguintes, articulou o golpe que afastou Vargas do poder, em dezembro daquele ano. Manteve-se à frente do ministério até setembro de 1946, quando 0 novo governo, chefiado pelo general Dutra, já havia tomado posse. Em 1947, elegeu-se senador por Alagoas, na legenda do Partido Social Democrático (PSD). Em 1950, recusou convite de Vargas para ocupar o posto de vice-presidente em sua chapa, na eleição presidencial daquele ano. Nesse mesmo ano, não conseguiu obter sua reeleição ao Senado. Com a posse de Vargas, foi indicado chefe do Estado-Maior das Forças Armadas (EMFA), permanecendo no cargo até dezembro de 1952. Em seguida, foi nomeado ministro do Superior Tribunal Militar (STM). Morreu no Rio de Janeiro, em 1956.
} 
militar nos currículos de formação de oficiais e a geografia volta como disciplina obrigatória como aponta MYAMOTO (1981:92). "A partir desta década, pósrevolução de 1930, principalmente com Góes Monteiro - responsável pela volta da Geografia Militar nos currículos do Exército em 1934". Ao analisar o episódio da revolução de 1932 (GOES MONTEIRO apud LOPES, 2010) aponta a importância da Geografia nas análises de uma guerra civil partindo de São Paulo.

A posição de São Paulo é forte, comparado a seu estado de preparação para sustentar a guerra civil com o restante do país empobrecido, sem recursos acumulados e na maioria dispersos. (...) A potência militar de São Paulo resultou de uma preparação cuidadosa, parte ostensiva, parte secreta, até é escolha do momento julgado oportuno para empenhar a luta armada. O terreno quer do ponto de vista geográfico, quer do ponto de vista topográfico e quer se considere do ponto de vista de recursos econômicos, industriais e das vias de comunicação, oferece toda espécie de vantagens aos paulistas.

PAULA CIDADE (1940) conclui sua apresentação ressaltando a importância dos estudos de geografia militar no Brasil, a relevância da sua obra no campo bibliográfico específico e a orientação da Missão Militar Francesa na sua obra.

As ideias que ficam esboçadas podem ser aceitas ou rejeitadas, ao todo ou em parte, mas de qualquer modo representam uma estrada nova que as gerações futuras hão de percorrer, criando para nossos problemas militares soluções mais adequadas do que as atuais, baseadas nas condições geográficas da América do Sul. Só depois surgirá entre nós a obra que há de ser considerada um modelo no gênero e não uma simples iniciação, como muitas que hão de aparecer e como este modesto trabalho, em que o autor é o primeiro a reconhecer muitas falhas e grandes defeitos, estes principalmente no que diz respeito à forma, mal cuidada pela exiguidade de tempo para poli-la. Finalmente, é preciso que fique bem claro que as conclusões nada têm de oficiais; pertencem exclusivamente ao autor, tendo tenente-coronel Langlet, da Missão Militar Francesa, que pela sua condição de oficial estrangeiro certamente limitou sua tarefa ao lado técnico das questões. (PAULA CIDADE, 1940, 05) 
Entretanto, assim como a sua causa perdida quando era parte dos "jovens turcos", a geografia-militar frente a ideia de Poder Nacional e da geopolítica irá, aos poucos, se tornando um raro produto esporádico de esforços individuais, enquanto o coletivo dos oficiais irão se ater a "causas maiores".

Cabe anotar que "Notas de Geografia Militar Sul-americana" apresenta um grande marco para história do pensamento militar brasileiro, pois em boa medida, representa uma coleção de aula mimeografadas da Escola de Estado-Maior, como afirma o próprio autor em "Síntese de três séculos de literatura militar brasileira" (1959:379):

As notas de Geografia Militar Sul-Americana, pelo então Major F. de Paula Cidade, aparecidas em 1934, reeditadas em 1940 pela Biblioteca Militar, pertencem ao ciclo do comando do General José Pessoa naquele estabelecimento de ensino. Representam uma aplicação da geografia ao pensamento militar brasileiro. Originalmente, tratava-se apenas de uma coleção de aulas mimeografadas, que o autor distribuía aos alunos da Escola Militar. O comandante da Escola Militar resolveu mandas imprimir esses polígrafos, bem como de outros professores, pondo-os à disposição dos alunos pelo preço de custo. O próprio autor pagou de seu bolso um certo número de exemplares, que ofereceu a alguns amigos. Assim surgiu a edição de uma obra que teve a boa fortuna de ser bem recebida no Brasil e no estrangeiro.

O "esquecimento" da geografia militar no bojo de matérias ensinadas na Escola Militar pode ser entendido como uma tentativa de se isolar a influência dos "jovens turcos" dentro da formação do exército nacional. Em comentários do próprio geógrafo militar, depois de sua transferência para o $17^{\circ}$ Batalhão de Caçadores de Corumbá, a geografia militar, simplesmente, desaparece dos currículos da Escola Militar, como afirma o autor (1959:379380).

Com a saída do General Pessoa daquele importante comando e com o afastamento do então Tenente-coronel $\mathrm{F}$. de Paula Cidade, que aceitou de boa mente o convite que Ihe foi feito para comandar o $17^{\circ}$ Batalhão de Caçadores e a fronteira de Corumbá durante a guerra do Chaco, o estudo de geografia militar desapareceu dos programas do ensino do Exército. Foi a tentada infrutiferamente numa dessas escolas a substituição do autor de Notas de Geografia Militar Sul-americana por professor civil. Parece não ter 
compreendido que a geografia militar é também o estudo da operativa à luz da geografia. E operativa é matéria militar transcendente, ao alcance de militares que tenham realizado altos estudos no campo profissional.

Num último esforço (grito) que Paula Cidade irá notar, a modernização do exército brasileiro deveria ser acompanhada da modernização dos estudos de geografia militar. Tirando assim as limitações dessa disciplina que historicamente esteve relacionada, apenas, com os estudos de campo, muito ligados a geografia física. Essa modernização do campo da geografia iria levar o entendimento mais amplo das condições espaço geográfico brasileiro o que apontaria quais os caminhos da modernização do exército nacional. A geografia apontaria os caminhos para tal condição.

Da apresentação desta obra pode-se concluir que a geografia militar é estudo de gabinete e não trabalho de campo. Isso porque tal disciplina não se ocupa de minúcias, que devem ser reservadas aos conhecimentos militares, que se destinam a completar as bases de qualquer operação de guerra. Basta ver que o domínio da moderna geografia militar é muito mais vasto do que o da geografia física, dada a generalidade permitida pela sua definição: "Estudo da influência que os elementos geográficos exercem sobre as operações de guerra". É esta razão pela qual nesta obra foi alargado o âmbito da geografia militar, que, de acordo com muitos dos antigos autores, se restringia apenas ao campo da geografia física, ou pouco mais, deixando de parte os restantes elementos que modernamente são abarcados pela geografia. Em nossos dias, em face da guerra total, não é sequer concebível tal limitação. PAULA CIDADE, 1959:380381)

É por esse motivo que a Geografia Política e a Geopolítica irão dominar a cena nas analises militares do espaço geográfico. A Geografia Militar terá uma forte concorrente no final do século XIX até o fim da Guerra Fria, a Geopolítica. É verdade que com o surgimento da Geopolítica e da Geografia Política, o emprego teórico-ideológico que a Geografia tem quando combinado com a Política atraiu mais os pesquisadores que foram desenvolvendo e aprofundando este campo teórico em detrimento da velha disciplina que se reduziu ao emprego prático ligado ao campo da Engenharia Civil, ou seja, na construção de edificações militares e suas localizações. Com a institucionalização civil da Geografia, o arcabouço teórico e as demandas pelo 
entendimento social do espaço terrestre atraíram mais o olhar dos pesquisadores. A criação do IBGE (1938) e das escolas de geografia civil, em boa medida, acentuou de forma definitiva a cisão Geografia Geral da Geografia Militar ${ }^{50}$; e, o estudo das antigas aplicações da Geografia na esfera militar foi caindo em desuso.

\section{A Missão Militar Francesa: geopolítica e a construção do poder aéreo.}

A Missão Militar Francesa trouxe um debate muito importante para o exército nacional, qual deveria ser a orientação teórica da modernização do exército nacional. No centro desta discussão surge uma polarização ideológica sobre qual orientação deveríamos tomar. De um lado, uma ala das forças armadas ligado ao alto oficialato de uma geração mais velha que bebeu muito da grande influência francesa que sempre permeou a formação dos oficiais brasileiros. De outro lado, jovens oficiais que como fora descrito foram em missão para Alemanha fazer estágio com a intenção de absorver as práticas militares modernas, esses jovens oficias são os "jovens turcos", fundadores da revista "A Defesa Nacional". Com o fim da primeira guerra mundial, o contrato com a Missão Militar Francesa parecia um caminho sem volta.

Sobre essa questão, PAULA CIDADE (1959:364) no Capítulo V intitulado "Da chegada da Missão Militar Francesa aos nossos dias", explica a polarização e como os "jovens turcos" aceitaram a posição sobre a modernização que seria realizada com a Missão Militar Francesa. "A missão foi não obstante muito bem recebida. Percorreu inicialmente todas as grandes guarnições brasileiras, numa tomada contato com o nosso meio militar" (ibidem). Para o jovem turco a crítica não deveria ser feita em relação ao contrato com a missão, como foi feita por muitos, que diziam que deixar a formação do oficialato na mão de estrangeiros era um problema de defesa nacional, que desta forma os franceses conheceriam nossos pontos fracos,

\footnotetext{
${ }^{50}$ Ver:

PENHA (1994): "A criação do IBGE no contexto na centralização política do Estado Novo". Rio de Janeiro, IN: "Documentos para disseminação", Memória Institucional - 4.

ARANHA (2014): "O IBGE e a consolidação da geografia universitária brasileira". "Terra Brasilis (Nova Série), IN: . URL : http://terrabrasilis.revues.org/971 ; DOI : 10.4000/terrabrasilis.971
} 
mas o problema era mais brasileiro do que francês, parafraseando o próprio autor. É um desabafo e uma crítica ao exército brasileiro que no auge de sua deficiência precisou da ajuda de experts estrangeiros.

Nunca, porém pode entrar no Estado-Maior do Exército, do qual foi desde logo considerada simples órgão consultivo. $\mathrm{Na}$ realidade, essas consultas reduziam-se a questões de instrução e não aos nossos altos problemas militares, os quais eram abordados de longe e nas suas generalidades especulativas. Conversas ocasionais... A explicação que se deixava entrever ou que se dava na intimidade era a de que seria perigoso para defesa nacional confiar estrangeiros segredos de tão especial significação. Um temor ingênuo de que outros países viessem saber que a situação brasileira, no que dizia respeito a planejamentos defensivos, estava ainda na estaca zero. Na verdade, tratava-se de um segredo de Polichinelo. Os especialistas da Missão desde os primeiros contatos com 0 nosso meio militar teriam descoberto nossos pontos fracos e a falta de planos de defesa, cujas bases racionais naquele tempo o próprio Estado-Maior não possuía. O principal obstáculo à entrada da Missão no Estado-Maior do exército era antes um caso brasileiro do que francês ${ }^{51}$ : o exagerado amor próprio de chefes que não podendo (como já vimos) ou não querendo fazer pessoalmente certos trabalhos, não concordavam em que oficiais das novas gerações os fizessem sob a direção pelo menos a começo - dos especialistas franceses. (PAULA CIDADE, 1959: 365)

A crítica ácida do "jovem turco" na verdade é mais um desabafo por se ver submetido ao oficialato francês, embora reconhecesse a importância da missão na modernização do exército nacional. Entretanto é também ingênuo demais acreditar que a missão não deixava o Brasil vulnerável à França, o imperialismo francês. É verdade, que o geógrafo militar brasileiro faz uma crítica velada a Missão Militar Francesa, mas de forma disciplinada se resigna ao comando e faz a autocrítica. Não se pode esquecer que a divisão do Brasil

\footnotetext{
${ }^{51} \mathrm{Na}$ realidade esquemática isso não pode ser afirmado de forma alguma, embora a crítica deva ser lida nas entrelinhas, pois nelas o autor do ponto de vista teórico-metodológico, o autor não acredita na via da Missão Militar Francesa como a melhor para a modernização do exército nacional.

BASTOS FILHO (1994:108): "A principal novidade do contrato de 1933 foi ficar estabelecido que, da equipe francesa, deveriam constar quatro oficiais de Estado Maior, os quais, por suas qualificações ou estágios anteriores, credenciavam-se junto às quatro respectivas Seções do Estado Maior de nosso Exército. Eram elas: 1a Seção, pessoal; 2a Seção, informações e contrainformações; 3a Seção, emprego e instrução; 4a Seção, administração e suprimento. Assim, em qualquer área, o que fosse tratado no alto escalão de nossa Força Terrestre estaria, possivelmente, ao alcance de um elemento da Missão".
} 
em regiões militares foi uma das realizações feitas pela missão contratada em 1932.

Do contrato assinado em 1932, destacamos que os oficiais franceses do Estado Maior do Exército, podiam ser encarregados de missões temporárias junto aos EstadosMaiores das Regiões Militares. O território nacional estava, e assim perdura, dividido em tais Regiões, cujos EstadosMaiores incumbem-se de estudos locais, como referente a mobilização indústria e de pessoal, recurso de toda ordem, vias de acesso, características da população, alvos estratégicos e informações. Os franceses podiam ter acesso a estes estudos, ao mesmo tempo em que se familiarizavam com as diversas áreas de nosso País. (BASTOS FILHO, 1994: 108)

Da mesma forma, depois da Segunda Guerra Mundial entra em cena os Estados Unidos que influenciará a formação dos oficiais brasileiros por intermédio da figura do General Golbery. Ao aceitar que a Missão Militar Francesa dirigisse e coordenasse vários setores das nossas forças terrestres ficávamos vulneráveis ao serviço de inteligência francês.

Neste ponto entendemos poder responder a pergunta que
nos fizemos. Para o Estado francês, através da Missão, o
Brasil foi um país, na área do Exército, sem segredos táticos
ou estratégicos. Os militares contratados dirigiram as
escolas, impuseram-Ihes currículos; chefiaram fábricas,
estipularam-lhes a produção; viajaram oficialmente em
nosso País, conheceram-lhe, e estudaram, características,
recursos, potencialidades, pontos vulneráveis; conviveram
com o homem brasileiro sabendo o que esperar de nossos
oficiais e soldados. Foram cerca de vinte anos, tempo mais
do que suficiente para, perfeitamente, informarem-se sobre
tudo que Ihes podia interessar. (BASTOS FILHO, 1994: 108)
veio a missão militar realizar no Brasil? Primeiro, modernizar o exército nacional; segundo, regionalizar a organização do exército nacional; terceiro, criar o poder aéreo; quarto, implantar uma doutrina de Poder Nacional; quinto, formação de oficiais segundo a sua doutrina. Foram criadas, pela Missão Francesa, cinco escolas para formação de oficiais: a Escola de Estado-Maior, a Escola de Aperfeiçoamento de Oficiais, as Escolas de Intendência e de Administração, a Escola de Veterinária do Exército e a Escola de Aviação. Percebe-se a importância sobre dois pontos combinados, o Poder Nacional e o poder aéreo. 


\section{A apropriação meridionalista da geografia militar: a guerra revolucionária, a guerra de guerrilha.}

Sobre a questão da Geografia Militar e sua apropriação e uso contra o imperialismo foi observada a importância da geografia nas guerras assimétricas que, principalmente, após as Grandes Guerras se tornaram no meio pelo qual os povos do sul se organizaram para fazer frente ao uso do hard power das potências imperialistas. Inúmeros são os exemplos de marchas populares que venceram o imperialismo por meio da guerra de guerrilha: a Revolução Cubana, as guerras de independência na África, as Guerras do Vietnã, as guerrilhas latino-americanas no contexto da Guerra Fria.

No Brasil, as esquerdas revolucionárias irão ser polarizadas, no período do regime militar, pelo embate de luta armada versus luta civil clandestina. A parte favorável à luta armada fora fortemente influenciada pela Revolução Cubana e pela guerrilha do Vietnã. Muitos foram os militantes que fizeram estágios nesses países, o melhor exemplo histórico é a figura de Carlos Marighella que escreverá uma importante obra sobre a guerrilha intitulada "Mini manual do guerrilheiro urbano" (1969) ${ }^{52}$. Marighella ao que tudo indica teria ido para Cuba e Vietnã, antes de voltar ao Brasil e partir para luta armada.

Sem dúvida o exemplo mais vitorioso no campo de batalha na luta contra o imperialismo fora o caso do Vietnã e a visão de seu General Von Nguyen Giap, que nunca perdeu uma guerra para imperialismo (Japão, França e Estados Unidos) e usou o meio geográfico a seu favor. Na prática e na teoria, pois foi combatente e analista da Guerra em seu clássico "Manual de Estratégia Subversiva", usou a geografia com fins militares e de libertação nacional.

Dois nomes foram muito importantes na ofensiva vietcong: Ho Chi Minh e o General Giap. Eles conduziram a guerra em três fases: inicialmente ataques isolados tipo guerra de guerrilha; depois ataques mais vultuosos, como os ataques a "Linha McNamara" e as bases em Khe Sanh e Gio Com Thien onde muitos vietcongs morreram; e no fim, quando o balanço das forças favorecessem, seria a hora das ações convencionais. Fora a mesma tática,

\footnotetext{
${ }^{52}$ Edição digital (2003):
} 
com respeito as rápidas evoluções de combate, usada no cerco de Dien Bien Fhu em 1954 contra o colonialismo francês.

A Trilha Ho Chi Minh começou a ser construída durante os anos 50 nas guerras de independência do Vietnã (como os vietnamitas chamam o período que vai da invasão japonesa na Segunda Guerra Mundial até o fim da Guerra do Vietnã em 1974). Foram abertas estradas e perfurado túneis em toda a região do confronto que pudesse ligar o norte com o sul. No país, homens, mulheres, garotos e garotas estavam dedicados a apoiar as forças com material necessário como armas, munição, comida, medicamento, informação. O Exército do Vietnã do Norte começa a ser um exército regular e bem treinado com uma excelente movimentação pelo terreno e bastante determinação. Seu armamento passa a ser exclusivamente soviético, ou seja a logística do abastecimento das munições é homogeneizado. Tudo isso foi ignorado pelo alto escalão dos oficiais das Forças Armadas dos Estados Unidos. Os estadunidenses acreditavam mais no fracasso das forças francesas do que na organização tática e estratégica do Vietnã do Norte.

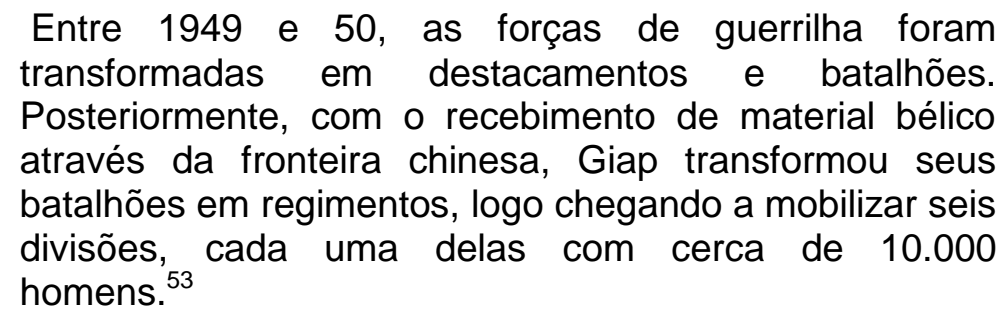

Depois do cerco a Dien Bien Fhu e com a rendição da França, que já recebia apoio dos Estados Unidos, vietnamitas e franceses sentaram-se a mesa de reuniões em Genebra em 1954 e o resultado das reuniões foi a formação de dois novos Estados: o Vietnã do Norte e o Vietnã do Sul divididos no paralelo $17^{\circ}$. Mas a organização do Vietnã do Norte foi impressionante, montando uma maquina estatal capaz de influenciar a região e expandir o comunismo na região.

Sobre a influência da geografia do teatro de operações de guerra de Dien Bien Fhu, Giap afirmou:

\footnotetext{
${ }^{53}$ In: www.esao.ensino.eb.br/paginas/.../insuficiencia e abundancia- acesso dia 5 de janeiro
} 
Dien Bien Phu era um campo entrincheirado muito poderoso. Todavia, estava localizado numa região montanhosa, em terreno que nos era favorável e decididamente desvantajoso para o inimigo. Além do mais, Dien Bien Phu era uma posição completamente isolada, muito longe de todas as bases inimigas. A única forma de reabastecer Dien Bien Phu era pelo ar. Estas circunstâncias poderiam retirar facilmente ao inimigo toda a iniciativa e força-lo à defensiva caso fosse atacado. (GIAP, 2005: 152)

A tática usada para cercar e vencer o inimigo teve como suporte uma ação logística de impedir o inimigo de reabastecer suas posições, estrangulando todos os canais de ligação (aéreo, terrestre e marítimo) e tomando as posições do inimigo onde era mais fraco, como descreve o próprio GIAP (2005:157).

Em resumo, o nosso plano de operações, baseado nestas condições táticas, consistia em estabelecer todo um sistema de linhas de ataque e de cerco, permitindo às nossas forças lançarem ataques sucessivos para aniquilarem o inimigo. Esta rede de inúmeras trincheiras, com posições de fogo e postos de comando, cercou e estrangulou o inimigo, alargando-se progressivamente com as nossas vitórias. Das montanhas e florestas circundantes, descendo para o vale. Depois de destruída, cada posição inimiga era imediatamente transformada numa posição nossa. À medida que cercávamos o campo fortificado inimigo, foi tomando forma um verdadeiro campo entrincheirado nosso, muito móvel, que continuava a aproximar-se enquanto o campo inimigo era constantemente reduzido.

A Revolução Cubana (1959) influenciaria todo um debate sobre quais deveriam ser os métodos de tirar os governos autoritários transformando a luta contra um governo autoritário e pró-imperialista numa luta de classes que levaria ao Brasil a sua revolução socialista. Não só muitos guerrilheiros se brasileiros se formaram em Cuba como muitos teóricos estudaram seu caso como um parâmetro de uma guerrilha que conseguiu subverter a ordem e se transformou numa Revolução da ordem político-institucional do país. Entretanto como foi apontado por Florestan Fernandes em sua obra intitulada "Da guerrilha ao socialismo: a Revolução Cubana" (1979), as condições de cada país da América Latina irão revelar novas estratégias e táticas a serem perseguidas. O exemplo de Cuba deveria ser ponderado e adaptado a cada situação geográfica. 
Essa via armada - embora instrumental e intrinsicamente política - de chegar-se ao socialismo só teve semelhante importância em Cuba. Ela aparece por si mesma, como a "política por outros meios" na única forma possível. Por isso, é preciso discuti-la aqui, pelo menos para assinalar dois pontos centrais: $1^{\circ}$ ) o que confere à guerrilha essa força histórica tão decisiva, criadora e surpreendente; $2^{\circ}$ ) porque a guerrilha e o guerrilheiro desaparecem, mas o espírito da guerrilha dura até hoje, identificando-se como o próprio espírito da revolução cubana. (...). Quanto ao significado revolucionário da guerrilha para desagregação do capitalismo e a passagem ao socialismo, o livro de Régis Debray preserva todo o seu valor, desde que se entenda e se redefina a problemática de uma perspectiva leninista (a situação revolucionária não foi improvisada ou fabricada em Cuba: sem ela, a guerrilha estaria provavelmente fadada ao fracasso, como sucedeu em outro países). Isso não significa que Cuba "não se repetirá" (uma concepção imperialista e contra-revolucionária), mas que outros países da América Latina terão de buscar suas vias próprias da revolução socialista, imitando os cubanos em tudo que for possível mas permanecendo abertos, como eles, às exigências concretas da situação histórica. (FERNANDES, 1979:71)

Filho dessas duas concepções a do Vietnã e a de Cuba e adaptando as condições do espaço geográfico brasileiro a sua teoria, Carlos Marighella escreveu sua obra (op.cit, 1969) considerando as condições do meio foi específico na questão da guerrilha urbana. A condição geográfica mais uma vez aparece no cerne da questão militar contemporânea, o urbano e o rural. Sua opção pela guerrilha urbana é uma ação direta e nas condições do momento, sem uma guerrilha rural bem organizada estava fadada ao fracasso, como predisse em sua própria teoria. Assim, para MARIGHELLA (2003), a guerrilha urbana serve a guerrilha rural, é a ação mais direta para se conseguir recursos para apoiar a guerrilha rural. A tradição colocada pela coluna Prestes (1925-27) mostrava a importância de conhecer as condições sociais que a população sertaneja brasileira estava submetida. Por isso, o teórico revolucionário acreditava que a guerrilha urbana deveria criar um suporte para a guerrilha rural diante das grandes transformações sociais que o Brasil havia vivido; na década de 20, o país era rural, no final da década de 1960 já era urbano.

É uma técnica que busca o desenvolvimento das guerrilhas urbanas, cuja função é desgastar, desmoralizar, e distrair as forças inimigas, permitindo $o$ desenvolvimento $e$ 
sobrevivência da guerrilha rural que esta destinada a um papel decisivo na guerra revolucionária. (MARIGHELLA, 2003: 18)

Embora o "Mini manual" seja uma literatura específica para organização da guerrilha urbana nas entrelinhas está uma discussão que é muito cara ao Brasil, a questão da "segurança nacional". As combinações de forças internas rurais e urbanas poderiam subverter a ordem e transformar as condições jurídicas, políticas e econômicas, numa ação de libertação nacional do imperialismo americano. A conjuntura, entretanto, não permitiu que as forças revolucionárias tivessem sucesso diante do movimento contrarrevolucionário que as sucumbiu. $\mathrm{O}$ alto comando do exército classificava e ainda classifica essas forças como "inimigos internos". Contudo, atualmente surge na visão da formação dos novos oficiais brasileiros um entendimento de que o imperialismo americano não vê com bons olhos a modernização das forças armadas brasileiras.

A guerrilha do Araguaia (1967-1974) que tinha como objetivo estabelecer a guerrilha rural foi o episódio que mais gerou baixas no exército nacional desde a Segunda Grande Guerra Mundial, vale lembrar que neste conflito morreram mais soldados do exército nacional do que das forças guerrilheiras, entretanto o uso de métodos violentos e criminosos - por parte das forças regulares do Estado - levaram a cabo o esforço revolucionário e pôs fim na tentativa de subversão da ordem por parte dos guerrilheiros.

A proposta do finado comandante Hugo Chávez para questão da segurança nacional frente a uma guerra imperialista foi um dos caros esforços de contribuir para relação guerra convencional ou guerra de guerrilha. PÁDUA (2012) em seu artigo intitulado "Milícia bolivariana: a materialização da nova relação civil-militar proposta por Hugo Chavez" analisa a proposta de Chavez sobre a importância de criar um quinto elemento dentro de suas forças armadas que são as milícias civis.

o presidente venezuelano, Hugo Chávez, vem implementando em seu país desde 2005, a formação da Milícia Bolivariana, quinto componente da Força Armada Nacional Bolivariana (FANB), sob argumento de se proteger de uma possível agressão à soberania de seu país por parte dos Estados Unidos, cujas intenções, segundo o mandatário 
venezuelano, ficaram evidentes com o golpe de Estado de 2002, que o tirou por 48 horas. (PÁDUA, 2012:92)

Entretanto, como aponta PÁDUA (2012), o acesso da população a armas tem aumentado muito a violência urbana e criando grupos bem abastecidos de armamentos que podem tentar conspirar desestabilizando 0 poder. Na conjuntura do espaço geográfico brasileiro essa política se mostraria amplamente desastrosa. Embora a ideia central desta política não seja descartável. No caso brasileiro devemos preparar nossas forças armadas a orientarem guerrilhas de uma forma mais hierarquizada. Em caso de conflito com grandes potências as nossas tropas terrestres terão que estar aptas a ensinar rapidamente a população insurgir contra as forças ocupantes. No entanto, sabemos que ainda a "Questão Militar" nos é muito cara. Muitas das críticas ácidas dos "jovens turcos" ainda poderiam ser feitas nos nossos dias. Um plano de defesa mais amplo pensando em condições desiguais de luta não é proposto pelo fato do Brasil não ter declarado nenhum inimigo externo. Construindo estradas, apoiando logisticamente a população sem habitação nos lugares mais longínquos, criando uma identificação que não seja apenas de força, mas que crie uma relação de suporte, de organização, autossuficiência, fortalecendo ao, mesmo tempo, a identidade nacional. Sem isso, a integridade territorial brasileira que sempre nos foi tão importante estará ameaçada de sobremaneira.

Esse debate está no cerne da discussão da "Questão Militar" e mais uma vez a geografia é o centro das respostas para o debate da Defesa Nacional. Devemos questionar, o alcance das nossas forças armadas frente ao desafio de cobrir todo o nosso imenso território é, visivelmente, deficitário do ponto de vista do poder territorial, como do marítimo, como do aéreo. Diante disso, quais são os nossos planos estratégicos para suprir esse déficit? Neste ponto que se percebe não haver uma orientação construída tanto pelos expert militares quanto pelos pesquisadores universitários que podem de forma coordenada construir planos apoiados em amplos estudos, envolvendo as Instituições de ensino Militares e Civis. Dessa forma unindo os esforços civis e militares poderemos ter, ao mesmo tempo, a modernização de nossas forças armadas e a da infraestrutura do transporte, ensino, pesquisa, transformação 
social entre outros tantos ganhos, alguns deles nunca alcançados até 0 presente momento. 


\section{CONSIDERAÇÕES FINAIS.}

O presente trabalho não pretendeu esgotar o assunto e nem tampouco abarcar todas as possibilidades que futuros trabalhos poderão realizar. Antes o presente trabalho teve a intenção de trazer para geografia universitária um trabalho específico com o temário da Geografia Militar no Brasil. Apontar possíveis trilhas a percorrer caminhos que podem ampliar os estudos de Geografia Histórica, Geografia Regional e Geopolítica. As opções teóricas de escolher um grande tempo histórico foram desafios enormes, porém necessários para alcançar o resultado que esperávamos. Discutir a Geografia tendo como o fio condutor a Defesa do território nacional.

A aproximação da Geografia com a questão da Defesa Nacional tange a "Questão Militar" que tanto se discutiu na passagem do século XIX para o século XX. Essa não é mais uma questão exclusivamente militar, se faz necessária a toda ordem uma reaproximação das instituições de ensino militar e civis para a tarefa de elaborar um plano de Defesa em que as questões geográficas podem em muitos casos, servir mais como uma força do que como um obstáculo. Essa questão transpassa todos os episódios e documentos pesquisados, a geografia como elemento de real importância para a Defesa do Território nacional. O espírito patriótico das Batalhas dos Guararapes, com suas colunas de pretos e índios; o conhecimento de dois Brasis com a Guerra do Paraguai e de Canudos. Esses episódios foram uma força motriz de produção intelectual e de elaboração do conhecimento geográfico. Esta análise demonstra um exemplo atual de como lidamos com questões nevrálgicas como planos de defesa do Estado, informações sobre conflitos, documentos entre outras coisas; apresentado ao leitor um grande crítico da política brasileira para estes assuntos, Visconde de Taunay. Sua obra, "A Retirada de Laguna" é apenas uma das inúmeras fontes vivas, que o presente trabalho estudou, de como se realizaram os planos de guerra e como foi negligente a política do Estado Maior, não aproveitando aquele momento para integrar regiões remotas de nosso país.

Atualmente, os problemas fronteiriços ainda são graves apresentando problemas na logística, estratégia e inteligência da defesa de nosso território, embora os possíveis inimigos não sejam mais os estados 
vizinhos, mas forças não estatais como o narcotráfico, grupos paramilitares e organizações criminosas. Estamos diante de um grande desafio. Vigiar uma extensa fronteira com aproximadamente 17 mil quilômetros, que faz divisas com dez territórios, ou seja, dez diferentes interesses.

Não é fácil controlar está fronteira, visto que, parte de nossos recursos socioeconômicos se concentra na faixada litorânea de nosso território, ainda hoje, quase $80 \%$ da população brasileira mora numa área que corresponde a 150 quilômetros da costa. Quais são as alternativas para este problema que envolve a segurança de toda a nação?

A Geografia Militar tem alguma coisa para responder sobre esta questão, pautada nos seus conceitos chaves: acessibilidade, mobilidade, visibilidade, comunicabilidade, disponibilidade e vulnerabilidade.

A acessibilidade, a primeira dos seis elementos da Geografia Estratégica, refere-se ao sentido físico do termo e, também, isto inclui condições das construções, organização espacial da população, tipos de estradas, rotas, distâncias. A mobilidade envolve a habilidade de se movimentar como um todo. Isto inclui a velocidade das unidades, a liberdade de escolher o sistema de transporte, o fluído do tráfego e engarrafamentos, os efeitos sazonais do clima, e a existência rotas prontas e facilidades terminais. A visibilidade abarca o campo de visão horizontal e vertical, ou do sensoriamento. Comunicabilidade significa a habilidade para transmitir informação. Isto inclui os efeitos do tempo atmosféricos, tempestades magnéticas, aspectos do território, existência sobre desenvolvimento cultural, facilidades de construção, eficiência operacional e manutenção dos sistemas de comunicação. Disponibilidade é uma palavra de uso comum, mas neste caso é aplicada a estratégia. Este conceito aparece em importância não apenas por expressar a existência de soldados, equipamento e suprimentos, mas também, por sua presença estar no lugar certo, na hora certa e na quantidade adequada.

Fechar os olhos para estes elementos na discussão da defesa do território nacional e, tão pouco, achar que eles resolverão completamente a questão. A concepção da Geografia Militar traz para análise, subsídios importantes para gestão da defesa do território e do controle das fronteiras, não são questões apenas para a diplomacia, mas para um amplo espectro de 
diversos setores da sociedade como as universidades, forças armadas, diplomacia e política.

Com o avanço da Geografia universitária nesses últimos cinquenta anos, as contribuições sobre a produção do espaço, planejamento territorial, política-territorial, organização do espaço, políticas urbanas, administração de parques nacionais, estudos sobre o uso do solo, cartografia, produção de cartas temáticas, imagem de satélites, linguística; inúmeras técnicas, teorias e produção de conhecimento do espaço geográfico com precisões e detalhes que contribuiriam muito para a discussão da Defesa Nacional. A "nação geopolítica" não poderá levar a discussão adiante sem toda a contribuição que a Geografia Moderna proporciona.

Pensar sobre defesa não é elencar ou declarar quem são os inimigos e, sim, quais podem ser os inimigos em diversos cenários. Podemos conjecturar da seguinte forma, se ocorrer um problema interno com algum vizinho, como estamos preparados, quais são nossas potencialidades? As respostas nesse caso nos dariam um alívio em saber que estamos bem e nossas potencialidades são enormes. Entretanto, num cenário em que enfrentamos uma potência além-mar, qual seria o nosso plano de defesa? Temos conhecimento de todas as potencialidades do nosso território para fins militares e temos um plano de defesa nacional capaz de envolver toda a nossa potencialidade? Não existe saída para essas perguntas que a resposta não passe pela Geografia. Se existe uma resposta positiva para essa pergunta? Neste ponto, o presente trabalho presta uma contribuição, aponta caminhos que podem ser percorridos, levanta uma bibliografia extensa sobre o assunto, acreditando ser apenas o começo e que muitos outros geógrafos e militares especializados em geografia possam ter canalizado sua produção neste estrito sentido. Mas, o realismo nos impele a ter como respostas negativas as duas últimas perguntas, assim sendo, a meta ainda está aquém para um país que pretende ser uma potência destacada no cenário mundial. 


\section{REFERÊNCIA BIBLIOGRÁFICA}

ABREU C. (2000): "Capítulos de história colonial, 1500-1800". Grandes Nomes do Pensamento Brasileiro. São Paulo, Publifolha, 280p.

ABRIL COLEÇÕES (2010): "Armas de Guerra", vol. 6 "Navios de Guerra" (1520-1899) e vol. 15 "Armas portáteis" (1870-1950)", São Paulo

ACUÑA C. (1994): "Novo Descobrimento do Rio Amazonas". Trad. ESTEVES, A. R. Edição bilíngue. Montevidéu, Oltaver S.A. Buenos Libros Activos,211p.

ADVERSE H. (2006): "Apresentação da edição brasileira". In: MAQUIAVEL, N. "A arte da guerra". São Paulo, Martins Fontes, $1^{a}$ Ed. 251p.

ALBUQUERQUE L. (1983): "Ciência e experiência nos descobrimentos portugueses". Lisboa: Biblioteca Breve, 131p.

ALVES J.V.P.F. (1979): "Mallet: o patrono da artilharia". Rio de Janeiro, Bibliex, 296p.

ARANHA P. (2014): "O IBGE e a consolidação da geografia universitária brasileira". In: "Terra Brasilis (Nova Série)", online no dia 30 de junho de $2014 . \quad$ URL : http://terrabrasilis.revues.org/971; $\quad$ DOI : 10.4000/terrabrasilis.971. (acesso em 18/01/2015).

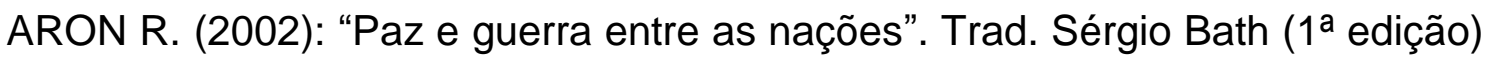
Brasília: Editora Universidade de Brasília, Instituto de Pesquisa de Relações Internacional; São Paulo: Imprensa Oficial do Estado de São Paulo, 2002, 936p.

. (1986): "Pensar a guerra, Clausewitz". Trad. de Elisabeth Maia Speller Trajano. Brasília, Editora Universidade de Brasília, 322p.

BACKEUSER E. (1952): "A Geopolítica Geral e do Brasil". Rio de Janeiro, Biblioteca do Exército, 1952.

BAERS J. (1898): "Olinda Conquistada”, Recife. 
BARLEUS G. (1980): "História dos feitos recentemente praticados durante oito anos no Brasil". Trad. Cláudio Brandão. Recife, Fundação de Cultura Cidade do Recife.

BARROS SILVA O. (1997): "Breve História do Tocantins e de sua gente - Uma luta secular". Tocantins: Solos Editores, 261p.

BARROSO G. (1938): "História Militar do Brasil". São Paulo: Companhia Editora Nacional, 2ª Ed., 1938, 346p.

BASTOS FILHO J. de A. (1994): "A missão militar francesa no Brasil". Rio de Janeiro, Bibliex, 163p.

BEIER R. (2012): "Em busca do ouro negro: uma aventura luso-brasileira de reconquista de Angola". In: http://umhistoriador.wordpress.com/2012/07/28/em-busca-do-ouro-negrouma-aventura-luso-brasileira-de-reconquista-de-angola-parte-1/ .

BERREDO B. P. (1749): "Annaes Históricos do Estado do Maranhão, em que se dá a notícia se seu descobrimento, e tudo mais que nelle tem sucessido desde o ano em que foi descoberto até o de 1718: oferecido ao augustíssimo monarca D. João V'. Lisboa. Impresso na Oficina de Francisco Luiz Ameno da Congregação Cameraria da Santa Igreja de Lisboa, 1749. $683 p$.

BITTENCOURT, A. de S. "Visitando Riachuelo e revendo controvérsias, 132 anos depois". Revista Marítima Brasileira, Rio de Janeiro, v. 117, b. 7-9, 2007, p. 42.

BLAY Jean-Pierre. (1994): "A missão militar francesa e sua influência na formação intelectual e tecnológica das elites militares brasileiras". Revista do Instituto de Geografia e História Militar do Brasil, Rio de Janeiro, n. 80, p. 8290.

BOBBIO N. (2003): "O problema da guerra e as vias da paz". Trad. Álvaro Lorencini. São Paulo: Editora UNESP, 2003. 
BONANATE L. (2001): “A Guerra”. São Paulo, Estação Liberdade, 175p.

BOYAJIAN J. C. (1983): "Portuguese bankers at Cort of Spain: 1620-1650". New Brunswick, Rutgers University Press.

BORGES J. V. (2005): "A Geografia Militar portuguesa: do século XV ao Futuro". In: http://www.jornaldefesa.com.pt/conteudos/view txt.asp?id=266. (acesso em 23 de abril de 2012).

BOSI A. (1994): "Uma história concisa da literatura brasileira". São Paulo, Ed. Cultrix, 527p.

BOULANGER P. (2002): "La géographie militaire française (1871-1939)", Paris,. Economica, 2002, $620 \mathrm{p}$.

BOXER C.R. (2011): "Império marítimo português, 1415-1825". Trad. Inês Silva Duarte. Lisboa, Edições 70, 2ª ed. 2011, 426p.

BOXER C.R. (1961): "Os holandeses no Brasil". São Paulo, Companhia Editora Nacional, 465p.

BRIGAGÃO C. (1983): "A corrida para a morte: desarme o mundo armado". Rio de Janeiro. Nova Fronteira, 1983.

(1984): "O mercado da segurança: ensaios sobre economia política de defesa”. Rio de Janeiro. Nova Fronteira, 1984.

BURTON R. (1997): "Cartas de campos de batalha do Paraguai". Rio de Janeiro, Bibliex, 1997.

CALADO Frei M. (1987): "O Valeroso Lucidênio". São Paulo, Editora Itatiaia/Edusp. Volume 1, 274p. Volume 2, 246p.

CANTARINO G. (2004): "Uma Ilha Chamada Brasil: o passado irlandês no passado brasileiro". Rio de Janeiro: MAUAD Editora, 2004, 408p. 
CARDOSO A. (2011): "A conquista do Maranhão e as conquistas atlânticas na geopolítica da União Ibérica (1596-1626)". In: Revista Brasileira de História, São Paulo, v.31, n61, p.317-338. .

CARMO J.A.R. (2006): "A batalha de Aljubarrota: Uma explicação geográfica". Dissertação apresentada para obtenção do grau de Mestre. Instituto Superior de Estatística e Gestão de Informação da Universidade Nova de Lisboa.

CASTRO T. (1980): "Geopolitica do Poder Mundial". In : A Defesa Nacional, ano $67, n^{\circ} 689,115-116 p$.

CEBRIAN F.P. (1985): "La geografia y la guerra: un analisis de sus relaciones". Madri: Servicio de Publicaciones Del EME, 1985.

CHIAVENATO J.J. (1979): "Genocídio Americano: A Guerra do Paraguai", Editora Brasiliense, 1979, São Paulo, 188p.

CLAUSEWITZ Von C. (2003): "Da Guerra". Trad. Maria Teresa Ramos. São Paulo: Martins Fontes, 2003, 930p.

CEPIK M. (2001): "Segurança Nacional e Segurança Humana: Problemas Conceituais e Conseqüências Políticas." In Security and Defense Studies Review. Vol. 1. Spring, 2001.

COELHO D. A. (2003): "Memórias Diárias da Guerra do Brasil". São Paulo: Editora Beca. 338p. Editado pela primeira vez em Madrid, 1654.

COLLINS John M. (1998): "Military Geography - for professionals and public". Washington, DC, 1998. National Defense University Press, 446 p.

CORDA H. (1921): "L'évolution des méthodes offensives de L'Armée Française: la recherche de la surprise pendant la Grande Guerre (1914-1918)". Paris: Gaup. 10 - 20 ARTIGO CIENTÍFICO 19 PADECEME Rio de Janeiro Edição Especial $2^{\circ}$ quadrim. 2005 thier-Villars,. 
COSTA T. G. (1997): "The Formation of defensive police in Brazil: Grand strategy and air power politics and doctrine during Cold War". Columbia University, 1997, 349p.

COSTA W. M. (1992): "Geografia Política e Geopolítica: discursos sobre o território e o poder”. Ed. Hucitec, São Paulo, 1992.

COUTO E SILVA G. (1967): "Geopolítica do Brasil". Livraria Olympio, Rio de Janeiro, 1967, 266p.

. (1981): "Planejamento Estratégico". Brasília, Ed. UNB, 536p.

CURTO D. R. (2011): "Uma história conservadora do Império marítimo português?". In: BOXER, C.R. "Império Marítimo Português, 1415-1825". Lisboa, Edições 70, $2^{\mathrm{a}}$ ed. 2011, 426p.

CORREA M.R. (2009): "Literatura brasileira: a crítica e a construção da identidade nacional”. Mafua, Florianópolis, ano 7, n. 11, março 2009.

CRESPO, H. \& PALACIO, J. M. \& PALACIOS, G. (2012): "La guerra del Paraguay. Historiografias. Representaciones. Contextos". Cidade do México, Ed. Colégio de México, Centro de Estudos Históricos, 453p.

DEBRET J. B. (1985): "Viagem pitoresca e histórica ao Brasil". São Paulo, Círculo do Livro, 691p.

DEMANT P. (2004): "O Iraque dilacerado: uma corrida contra o relógio". In: Revista Panorama da Conjuntura Internacional - GACINT - n21, ano 6, maio.

D’EU C. (1981): "Viagem Militar ao Rio Grande do Sul". Editora Itatiaia e EDUSP, São Paulo, 1981, 186p.

DOYLE, P. \& BENNETT, M.R. (2002): "Fields of Batle: Terrain in Military History". The GeoJournaul Library, 64. Kelwer Academic Publishers. Dordrecht. Netherlands. 
DONATO H. (1996): "Dicionário das Batalhas Brasileiras". São Paulo: IBRASA, 1996, 593p.

DORATIOTO F. (2008): "General Osorio. A espada liberal do Imperio". São Paulo, CIA das Letras, 2008, 262p.

. (2006): "Guerra do Paraguai". In: História da Guerra. Org. MAGNOLI, D. São Paulo, Ed. Contexto, 253-285pp.

(2002): "Maldita Guerra". São Paulo: CIA das Letras, 617p.

EHLEN J. \& HARMON R.S. (2001): "The Environmental Legacy of Military Operation. Reviews in Engineering Geology". XVI Geological Society of America. Boulder. Colorado.

ELLIOT J. H. (2004): "El Conde-Duque de Olivares. El político em la época de decadência" (1 ${ }^{\mathrm{a}}$ ed. Inglesa, 1986), Barcelona, Editorial Critica, 924p.

FERNANDES F. (1979): "Da guerrilha ao socialismo: a revolução cubana". São Paulo, Ed. T.A.Q., 231p.

FERNANDES J.S. \& ANDRADER. P. (1984): "Carros de Combate". Aquarius Editora e Distribuidora de Livros Ltda, São Paulo, 1984, 112p.

FONSECA L. A. (1991): "O Tratado de Tordesilhas e a Diplomacia LusoCastelhana no Século XV", Estudo de Luís Adão da Fonseca e Leitura de Maria Cristina Cunha, Lisboa, INPA.

FOSSATI L. (1974): "Rússia: pobre Nicky". In: "As últimas monarquias". Instituto Geográfico De Agostini, Novara. São Paulo, Editora Três, 1974.

FRAGOSO A. T. (2009): "História da Guerra entre a tríplice aliança e o Paraguai". Rio de Janeiro: BIBLEX, 454p.

FREIRE F. B. (2001): "Nova Lusitânia, História da Guerra Brasílica". São Paulo, Editora Beca. 353p. Editado pela primeira vez em Lisboa, 1675. 
FREITAS J. M. da C. (2004): "A escola geopolítica brasileira: Golbery do Couto e Silva, Carlos de Meira Mattos e Therezinha de Castro". Rio de Janeiro, Bibliex, 135p.

FREIXINHO N. (1994): "Brasil, os difíceis caminhos da integridade". Rio de Janeiro, Kosmos, 448p.

FROTA G. A. (2000): "Quinhentos anos de História do Brasil". Rio de Janeiro, Bibliex, 734p.

FURTADO J.F. (2011): "Guerra, diplomacia e mapas: a Guerra da Sucessão Espanhola, o Tratado de Utrecht e a América portuguesa na cartografia de D’Anville". Topoi: Revista de História da UFRJ. Volume 12, n²3, Julho de 2011.

GIAP Gal. V. N. (2005): "Manual de Estratégia Subversiva". Lisboa, Edições Sílabo, 189p.

GILEWITCH D. A. (2003): "Military Geography: The Interaction of desert geomorphology and military operation". Arizona State University, 2003, 316p.

GOÇALVES L. J. C. (2009): "TÁTICA DO EXÉRCITO BRASILEIRO NA GUERRA DO PARAGUAI ENTRE 1866 E 1868”. Dissertação apresentada ao Programa de PósGraduação em História da Faculdade de História, Direito e Serviço Social, Universidade Estadual Paulista "Júlio de Mesquita Filho".

GONZALES, S.L.M (2008): "A territorialidade militar no Brasil: os Tiros de Guerra e a estratégia da presença". Tese de Doutorado apresentada ao Programa de Pós-graduação de Geografia Humana da Faculdade de Letras, Filosofia e Ciências Humanas (FFLCH) da Universidade de São Paulo (USP).

GURGEL J. A. A. (1976): "Segurança e Democracia". Rio de Janeiro: Livraria José Olímpio Editora, 194p.

GROTIUS, H.(2005): “O Direito da Guerra e da Paz". Ijuí: Ed. Unijuí. 
GUIMARÃES, S. P.(2004): "Uma Estratégia Militar para o Brasil". In Reflexões sobre defesa e segurança: uma estratégia para o Brasil. Almeida Pinto, J. R. Et al. (organizadores) Brasília: Ministério da Defesa, Secretaria de Estudos e de Cooperação.

HARTH A. C. (2003): "Geopolitics and Grand Strategy: Foundations of American National Security". University of Pennsylvania, 2003, 475p.

HART B. H. L. (1967): "As grandes guerras da história". São Paulo: IBRASA, 1967, 514p.

História oral do exército. (2006): "Projeto Rondon, integrar para não entregar". Tomo 1. Rio de Janeiro: Bibliex, 450p.

HOLANDA S. B. (1989): "A época colonial". In: "História Geral da Civilização Brasileira". $8^{a}$ edição, Rio de Janeiro, Editora Bertrand Brasil, 389p.

JAGUARIBE, H. (2004): "Defesa Nacional: desafios e possíveis respostas do Brasil”. In Reflexões sobre defesa e segurança: uma estratégia para o Brasil. PINTO, J. R. A.; ROCHA, A. J. R. \& SILVA, R. D. P (Organizadores). Brasília: Ministério da Defesa, Secretaria de Estudos e de Cooperação.

JOBIM, N. (2010): "O Brasil e a Segurança do Atlântico Sul. Lisboa: Instituto de Defesa Nacional". (Palestra proferida no seminário "O futuro da Comunidade Transatlântica").

KEEGAN J. (2006): "Inteligência na guerra: conhecimento do inimigo, de Napoleão à Al-Qaeda". Trad. S. Duarte. São Paulo: Companhia das Letras, 448p.

(2005): "A Guerra do Iraque". Trad. Laís Andrade. Rio de Janeiro: Biblioteca do Exército, 287p.

(1995): "Uma história da guerra". Trad. Pedro Maia Soares. São Paulo: Companhia das Letras, 1995, 441p. 
KENNEDY P. (1989): "Ascensão e queda das grandes potências: transformação econômica e conflito militar de 1500 a 2000". Trad. Waltensir Dutra. Rio de Janeiro: Elsevier, 1989.

KIMBLE G.H.T. (2005): "A geografia da Idade Média”. São Paulo: Imprensa Oficial, 2005.

KISSINGER H. (1994): "Diplomacy". New York: Simon \& Schuster, 1994, 907p.

LACOSTE Y. (2008): "A geografia- isso serve em primeiro lugar, para fazer a Guerra". São Paulo, Papirus, $14^{\circ}$ edição.

LAET J. (1925): "História ou Anais dos Feitos da Companhia Privilegiada das Índias Ocidentais, desde o começo até o fim do ano de 1636". Trad. José Higino Duarte Pereira e Pedro Souto Maior. Rio de Janeiro. Biblioteca Nacional.

LAVALLÉE T. (1865): "Geógraphie physique, historique et militaire". Escola Especial de Saint-Cyr, $7^{\mathrm{a}}$ edition, Paris, Charpentier Librairie - editeur, 1865.

LEVY D. T. (2008): "Judeus e marranos no Brasil holandês: pioneiros na colonozação de Nova York (séculoXVII)". Dissertação de mestrado defendida no Departamento de História da FFLCH-USP.

LIDER J. (1987): “Da Natureza da Guerra”. Rio de Janeiro: Biblex, 370p.

LIMA R. M. (1989): "Senta a pua!" Rio de Janeiro: Instituto Histórico-Cultural da Aeronáutica, 465p.

LOPES (2010): "Goes Monteiro, biografia". IN: http://cpdoc.fgv.br/producao/dossies/Fatos/magens/biografias/goes monteiro. (acessado 22/03/2011).

LUIZ Francisco de S. (1841): "Índice Cronológico das Navegações, Viagens, Descobertas e Conquistas dos Portuguezes nos Paizes Ultramarinos". Lisboa. Imprensa Nacional, 1841. 283p. 
LUTTWAK E. N. (1987): "Strategy: The logic of War and Peace". London: Harvard Univerty Press, 1987, 282p.

LYNCH C. (2006): "Introdução". In: MAQUIAVEL, N. "A arte da Guerra”. São Paulo, Martins Fontes, 2006, 251p.

LYRA TAVARES A. (1979): "Brasil e França ao longo de 5 séculos", Rio de Janeiro, Biblioteca do Exército, 1979.

MAC CANN Frank D. (1985): "Influência estrangeira no Exército Brasileiro". A Defesa Nacional, Rio de Janeiro, n. 717.

MACHADO M.S. (2000): "A implantação da geografia universitária no Rio de Janeiro". Rio de Janeiro, GEOgraphia, vol. 2, №3,pp. 123-140.

MAGALHÃES J. B. (2001): "A evolução militar do Brasil". Rio de Janeiro: BIBLEX, 382p.

MAGNOLI D. (2006): “História das Guerras”. São Paulo: Contexto, 2006.

MALAN Gal. A. S. (1988): "Missão Militar Francesa de Instrução junto ao Exército Brasileiro". Rio de Janeiro, 183p.

MAQUIAVEL N. (2006): "Arte da Guerra". São Paulo: Ed. Martins Fontes, $1^{\text {a }}$ Ed. 2006, 251p.

MARIGHELLA C. (2003): "Minimanual do guerrilheiro urbano". Digitalizado em 2003, in: http://minhateca.com.br/marceloricci/Biblioteca/Livros+ ${ }^{*} 5$ bconte ${ }^{*}{ }^{*}{ }^{*}$ bado* $5 \mathrm{~d} /$ MARIGHELLA ${ }^{\star} 2 \mathrm{C}+$ Carlos.+Minimanual+do+guerrilheiro+urbano,84912921.p df . (acesso em 20/01/2014).

MARTIN A.R. (2007): "Brasil, Geopolítica e Poder Mundial - o anti-Golbery". Tese inédita para o concurso de obtenção do título de Livre Docente, São Paulo, março de 2007. 
(2006): "A guerra de secessão". - in: MAGNOLI, D. Organizador. História das Guerras. São Paulo: Contexto, 2006

(2004): "Geografia: Geopolítica e o poder mundial". CASTELLAR \& MARTINS, Organizadores. Pró-Universitário - Governo do Estado de São Paulo e Universidade de São Paulo.

MARTINS, L. M. (1997): "A estratégia naval brasileira na Guerra do Paraguai”. Rio de Janeiro, Revista Marítima Brasileira, julho-setembro de 1997, pp.5983.

MARTINS O. (1987): "História de Portugal". Lisboa: Guimarães Editores, ed. 19a. $471 p$.

MATTOS J. B. de. (1968): "Os ensinamentos franceses no Exército Brasileiro". Revista de Geografia e História Militar do Brasil, Rio de Janeiro, n. 56, p. 4462, 1968.

MEIRA MATOS C. Gal. (1980):“Uma geopolítica pan-Amazônica”, Rio de Janeiro: J. Olympio, 1980.

MELLO E.C. (2010): "O Brasil Holandês". São Paulo, Penguin \& Companhia das Letras, 511p.

MELLO F. P. (2007): "A Guerra Total de Canudos". São Paulo: A Girafa, 367p.

MELLO L. I. A. (1999): "Quem tem medo da Geopolítica?". São Paulo: Editora Hucitec, 1999, 228p.

. (1997): "A geopolítica do Brasil e a Bacia do Prata". Manaus: Editora da Universidade do Amazonas, 1997.

MELO F. M. (1944): "A Restauração de Pernambuco: A Epanáfora Triunfante e Outros escritos". Recife. Secretaria do Interior.

MORAES, J. Q. (1991): "A Esquerda Militar no Brasil: da conspiração republicana à guerrilha dos tenentes". São Paulo, Editora Siciliano, 169p. 
MOREAU P. (1979): "História das últimas batalhas entre os portugueses e holandese". Trad. Leda Boechat. São Paulo. Editora Itatiaia.

MORI V. H. "(2003):Arquitetura Militar, um panorama histórico a partir do Porto de Santos". São Paulo, Impressa Oficial do Estado de SP, 231p.

MORGENTHAU H. J. (2003): "A política entre as nações: a luta pelo poder e pela paz". Trad. Oswaldo Biato. Brasília: Editora Universidade de Brasília, Instituto de Pesquisa de Relações Internacional; São Paulo: Imprensa Oficial do Estado de São Paulo, 2003, 1152p.

MORTON L. (2004): "Primeiro a Alemanha: o conceito básico da estratégia aliada na Segunda Guerra Mundial". In: Segunda Guerra Mundial: as grandes decisões estratégicas, Rio de Janeiro, BIBLEX, 2004, 512p.

MOTTA, J. (1976): "Formação do Oficial do Exército (currículo e regimes na Academia Militar 1810-1944). Rio de Janeiro, Editora CIA de Artes Gráficas, $368 p$.

MYAMOTO S. (1981): "O pensamento geopolítico brasileiro (1920-1980)". Mestrado pelo Departamento de Ciência Política da FFLCH-USP.

NIEUHOF J. (1942): "Memorável Viagem Marítima e terrestre ao Brasil". São Paulo. Trad. Moacir Vasconcelos. Livraria Martins.

PÁDUA A. S. (2012): "Milícia bolivariana: a materialização da nova relação civilmilitar proposta por Hugo Chavez". In: V Encontro da ABED: Defesa, Segurança e Estratégia, 2012, pp. 91-105.

PAIM A. (2000): "Momentos Decisivos da História do Brasil". São Paulo: Martins Fontes, $1^{\mathrm{a}}$ Ed., 2000, 317p.

PALKA E.J. \& GALGANO, F.A. (2000): "The Scope of Military Geography: Across the Spectrum from Peacetime to War. MacGraw-Hill Primus". Nova York. 
PAULA CIDADE Gal. F de. (1959): "Síntese de Três Séculos de Literatura Militar Brasileira". Rio de Janeiro: Impresso no Estabelecimento General Gustavo Cordeiro de Farias, $1^{\stackrel{a}{ }}$ Ed. 1959, 607p.

, (1940): "Notas de Geografia Militar Sul-americana".

Rio de Janeiro, Biblioteca Militar, 1940,346p.

, (1948): Lutas, ao sul do Brasil com os espanhóis e seus descendentes". Rio de Janeiro: Edição da Biblioteca Militar, 324p.

PENHA E. A. (1993): "A criação do IBGE no contexto na centralização política do Estado Novo". Rio de Janeiro, IN: "Documentos para dissiminação", Memória Institucional - 4 .

. (1998): "Relações Brasil-África e Geopolítica do Atlântico Sul". - Tese de Doutorado, UFRJ.

PELEGRINO FILHO Maj. A. (2002): "A Influência da Missão Militar Francesa na ECEME”. Rio de Janeiro, 2002, ECEME, 18p.

PELTIER \& PEARCY (1966): "Military Geography". Princeton, New Jersey: D. Van Nostrand Company, INC. 1985, 176p.

PERLO V. (1969): "Militarismo e Indústria: armamentos e lucros na era dos projéteis". Trad. Eurico Remer \& Maura R. Sardinha. Rio de Janeiro, Paz e Terra.

PERRY M. (2002): "Civilização ocidental, uma história concisa”. São Paulo. Ed. Martins Fontes, 667p.

PIMENTA J.P.G. (2006): "Estado e Nação no fim dos Impérios Ibéricos no Prata (1808-1828). São Paulo, Ed. Hucitec, 2006, 266p.

POMEROY W.J. (1967): "guerrillas y contraguerrillas". - México D. F., Editorial Grijalbo, S. A. 
PORRO C. (1898): "Guida allo studio della Geografia Militare; compendio delle lezioni di Geografia Militare". Torino: Unione tipografico-editrice, 1898[1903.VII, 391p.

RAPOPORT A. (2003): "Prefácio". In: CLAUSEWITZ; Da Guerra. São Paulo, Martins Fontes, $2^{\mathrm{a}}$ Ed. $2^{\mathrm{a}}$ tiragem, 2003, 930p.

RANGEL I. (1982): "A economia dos anos 80. in: Ciclo, Tecnologia e Crescimento". Editora Civilização Brasileira, Rio de Janeiro, 1982, 172p.

RIBEIRO F.G.B. (2010): "A Nova Geografia Militar: Logística, Estratégia e Inteligência". Dissertação de Mestrado. FFLCH da USP. São Paulo Orientador: André R. Martin. 2010.

RIBEIRO W. C. (1994): "Os militares e a defesa no Brasil: a indústria de armamentos". Dissertação de Mestrado. FFLCH da USP. São Paulo Orientador: Prof. Dr. José William Vesentini. 1994.

RICHSHOFFER A. (1898): "Diário de um Soldado". Trad. Alfredo de Carvalho. Recife.

ROBERT MORAES A.C. (2002): "Ideologias Geográficas". São Paulo. Hucitec e Annablume, 2002, 156.

(2000): "Bases da formação territorial do Brasil: o território colonial brasileiro no longo século XVI". São Paulo. Hucitec, 2000, $431 \mathrm{p}$.

.(1990): Organizador. "Ratzel". São Paulo: Editora Ática, 1990. . (1989): "A gênese da Geografia Moderna". São Paulo: HUCITEC, Editora da Universidade de São Paulo, 1989.

RODRIGUES F. DA S. (2007): "Os Jovens Turcos e o projeto de modernização profissional do exército brasileiro". XXIV Simpósio Nacional de História. 
RODRIGUES L. A. (1978): "O rio dos Tocantins.", Obra reeditada pelo Governo do Estado de Goiás, 1978.

ROSTY C. S. (2011): "Campanha da Guiana Francesa: Caine tomada aos franceses". Revista Navigator, Vol. 6, n 11, dossiê 7, 2011, p. 43-51.

RUDZIT G. (1997): "O processo de formação do Oficial do Exército brasileiro \& A Geografia (1850-1930)". Dissertação de Mestrado apresentada ao Departamento de Geografia da Faculdade de Filosofia, Letras e Ciências Humanas da Universidade de São Paulo.

SALES T. H. (2009): "Guerra do Paraguai: Controvérsias da Historiografia sobre as causas do conflito". In: II Encontro Memorial: Nossas Letras na História da Educação, Universidade Federal de Ouro Preto, 2009.

SANTIAGO Diogo Lopes de. (1984): "História da guerra de Pernambuco". FUNDARPE, 1984. $596 \mathrm{pp}$

SANTOS M. (1994): "A natureza do espaço". São Paulo, Editora Hucitec, 1994.

SARAIVA A.J. (1985): "Inquisição e cristãos-novos”. Lisboa, Editorial Estampa.

SAWYER R. (2006): "Introdução". In: SUN TZU \& SUN PIN. "A arte da Guerra e Métodos Militares". São Paulo: Editora Martins Fontes, $1^{\underline{a}}$ Ed. $4^{\underline{a}}$ tiragem. 2006, 336p.

SECCO, L. (2013): "A Revolução dos Cravos: Dinâmica Militar". Projeto História - Revista do Programa de Estudos Pós-graduados de História, São Paulo, vol.47, pp.365-376, Agosto de 2013.

SODRÉ N. W. (1968): "História Militar do Brasil". Rio de Janeiro: Ed. Civilização Brasileiro, 439p.

SOUZA A. B. "(2008),Duque de Caxias, o homem por trás do monumento". Rio de Janeiro, Ed. Civilização Brasileira, 611p.

SUN TZU \& SUN PIN (2006): "A arte da Guerra \& Métodos Militares". Org. e trad. SAWYER: São Paulo, Ed. Martins Fontes, $1^{1}{ }^{\mathrm{a}}$ Ed. $4^{\circ}$ Ed. 2006, 336p. 
TORRES Gal. R. N. (2006): "A Guerra do Paraguai vista por um inglês". In: http://www.militar.com.br/modules.php?name=Historia\&file=display\&jid=115 - acesso em 13/01/2015).

TRAVASSOS Mario. (1919): "A Missão". A Defesa Nacional, Rio de Janeiro, n. 64 , p. 118 - 119, jan.

UNDERWOOD, JR \& GUTH, PL. (1998): Military Geology in War and Peace. Geological Society of America Reviews in Engineering Geology. Volume 13. Bounder, Colorado.

Uma testeminha ocular (1975): "Contribuições para a História da Guerra entre o Brasil e Buenos Aires". São Paulo: Ed. Itatiaia \& EDUSP, 311p.

VERSEN M. von. (1976): "História do Paraguai". São Paulo: Ed. Itatiaia \& EDUSP, 197p.

VISACRO A. (2009): "Guerra irregular". São Paulo: Ed. Contexto, 2009, 380p.

WATSON A. (2004): "A evolução da sociedade internacional - uma análise histórica comparativa". Trad. René Loncan.Brasília: Editora da Universidade de Brasília, 2004.

WINTERS W, GALLOWAY G. JR.,REYNOLD W, RHYNE D. (1998): "Battling the Elements: Weather and Terrain in Conduct of War". John Hopkins University Press, Baltimore.

WIZNITZER A. (1966): “Judeus no Brasil Colonial". São Paulo, Ed. Pioneira/Edusp.

WRIGHT Q. (1988): "A Guerra”. Rio de Janeiro: Blbliex, 372p. 
ANEXO 1 - PRIMEIRA BATALHA DOS GUARARAPES 1648
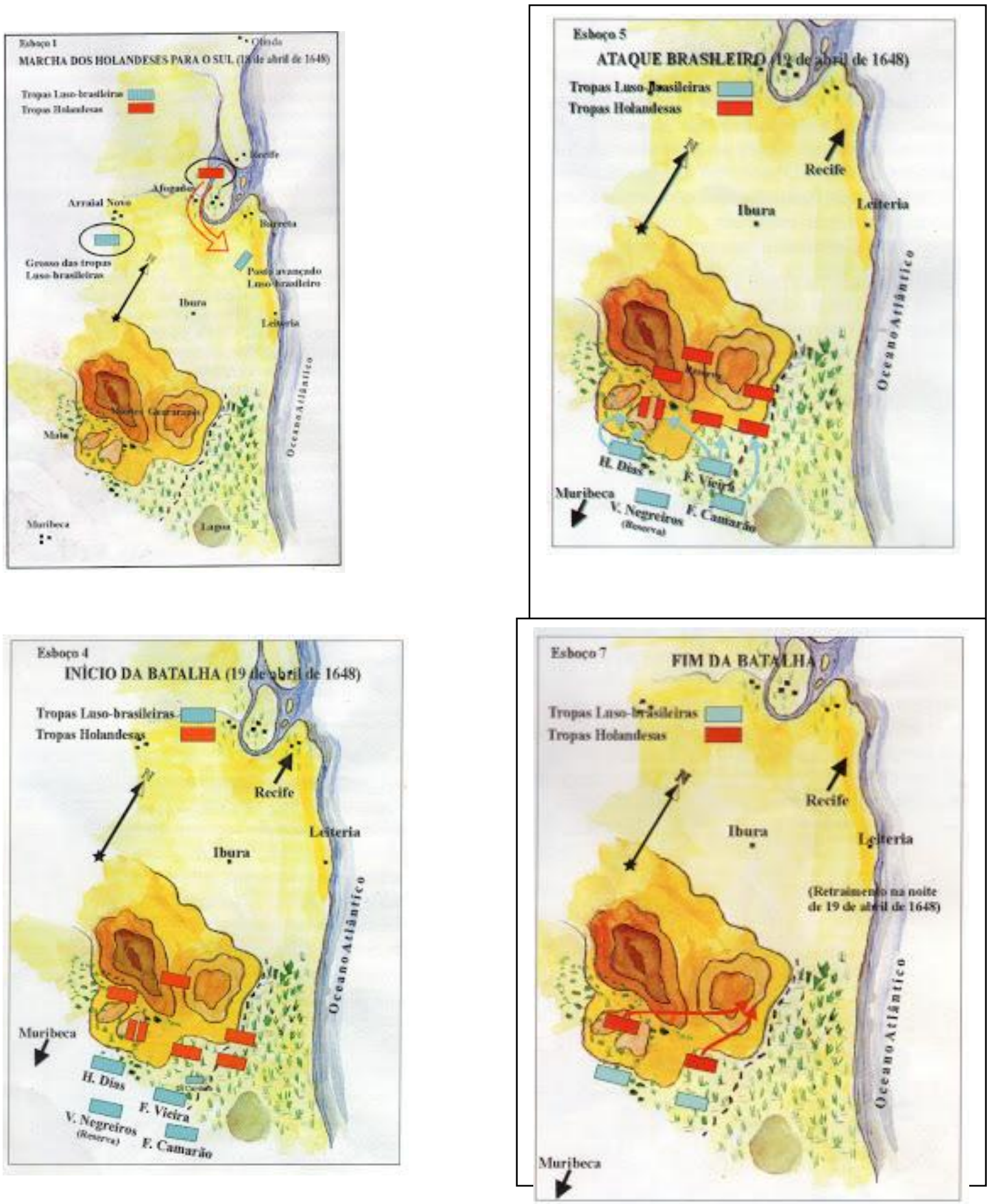

FONTE: http://amyschool.blogspot.com.br/2012/10/batalha-dos-guararapes-asbatalhas-dos.html (acessado em 13/01/2015) 

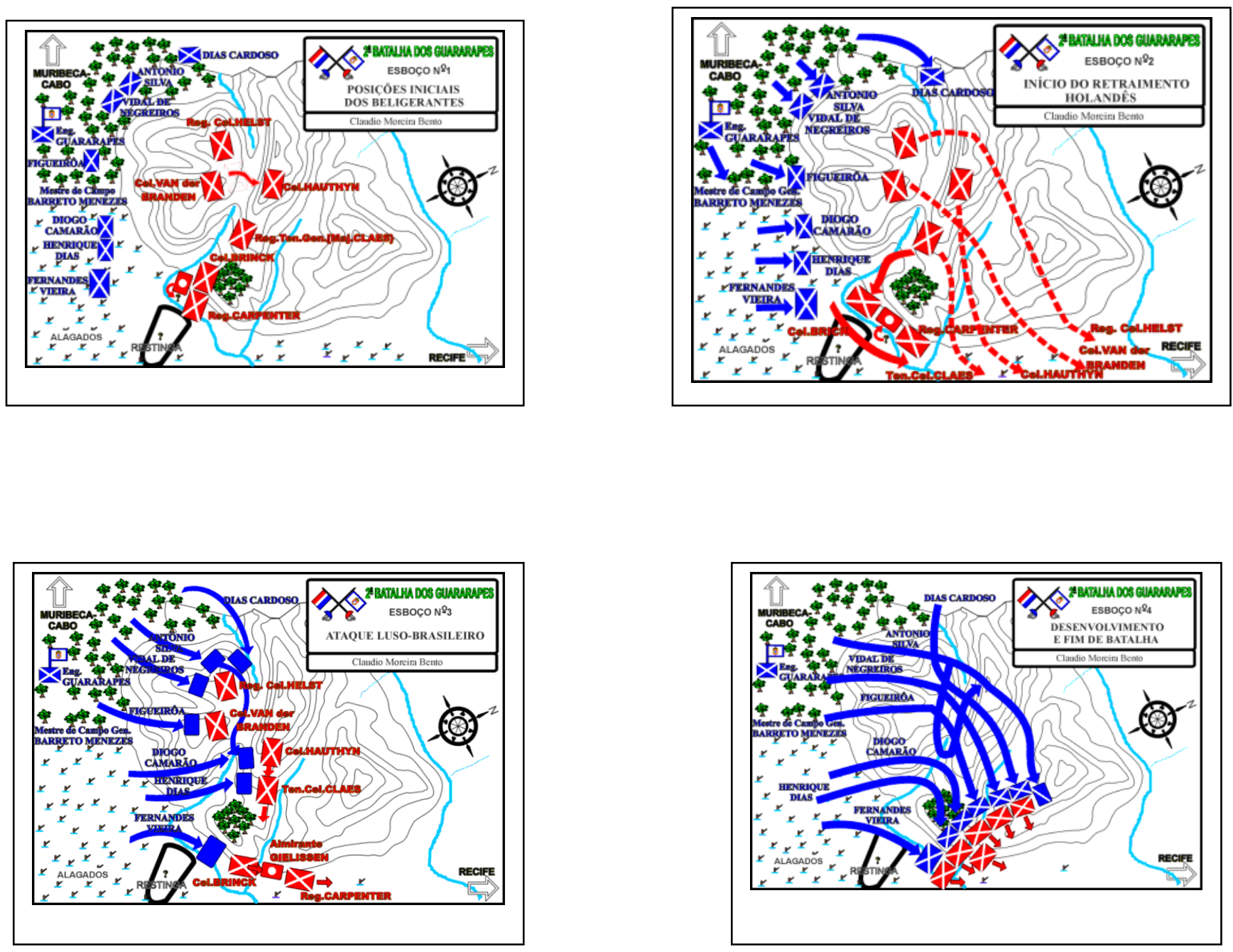

FONTE: http://www.ahimtb.org.br/3d.htm (acessado em 13/01/2015) 


\section{ANEXO 3 - DESCRIÇÃO DA SEGUNDA BATALHA DE GUARARAPES.}

\section{Posições iniciais dos beligerantes no dia da batalha}

\section{- Dos holandeses}

Os holandeses esperavam que os luso-brasileiros se apresentassem pelo norte, através do Boqueirão; foram, porém, surpreendidos com o adversário surgindo ao sul e retaguarda de seu dispositivo inicial.

Esta surpresa frustra por completo o combate que tinham planejado e sonhado durante longos meses no Recife e, repentinamente, veem-se diante de uma conduta de combate.

Surpresos, reajustam seu dispositivo, mudando a frente do norte para o sul no Boqueirão e ao longo da crista do monte onde se encontra atualmente a Igreja N. S. dos Prazeres.

Rebateram alguns regimentos em posição no Oitizeiro, próximo do Boqueirão, para o monte da Igreja N. S. dos Prazeres. Ao que parece, ficou no Oitizeiro uma parte da reserva.

Ao longo deste linha, articularam seis regimentos (ver esboço $n^{0} 11$ ).

Apoiaram o flanco leste nos alagados e o flanco oeste no atual movimento topográfico onde se ergue, hoje, a Igreja Nossa Senhora dos Prazeres.

Os holandeses passam toda a manhã aguardando o ataque. $O$ moral dos seus soldados começou declinar, por estarem expostos, em cima do monte da atual Igreja dos Prazeres, ao calor excessivo e sede mortificante, em razão da ausência de sombra e água nas partes superiores do dito monte.

A esta situação, eles não resistiriam por longo tempo; era preciso fazer algo.

Convocado um conselho de guerra, são discutidas e analisadas três linhas de ação.

\section{Interpretação do autor}

Linha de ação no 1

- Retrair à noite e em silêncio, rumando para Afogados, através da Várzea, fazendo toda a sorte de estragos nos domínios luso-brasileiros.

Contra esta linha de ação, argumentou-se: "A retirada à noite deporia contra a honra e reputação do Exército Expedicionário, porque seria interpretada como medo (Cel Brinck).

Linha de ação $\mathrm{n}^{0} 2$

- Descer os montes durante o dia e retrair para a Leiteria (Boa Viagem) onde passariam a noite.

Linha de ação no 3

- Prosseguir para o Cabo Santo Agostinho (zona de retaguarda brasileira). 
Ao êxito desta linha de ação, antepunham-se as diversas fortificações existentes na direção de ação e, principalmente, a travessia do rio Jaboatão, que estava fortificado.

Em caso de êxito, não teriam condições de manter a linha de suprimentos, por mar, através da Barra das Jangadas (rio Jaboatão).

No Conselho de Guerra de que participaram todos os coronéis, tenentescoronéis e majores, ficou decidido pela adoção da linha de ação $n$ o 2: retraimento diurno para a Leiteria.

\section{Comentários}

O Cel Brinck havia saído à campanha, baseado em informações recebidas através de dois italianos e alguns negros fugidos do Arraial. Informaram eles que o Exército Restaurador estava fraco, por ter Barreto de Menezes dispensado muitos soldados por motivo de economia para irem cuidar de suas plantações (Lopes Santiago).

Sabedor Barreto de Menezes, através de sua rede de espionagem no Recife, da intenção holandesa, mandou pressurosamente reunir o máximo de soldados.

No Recife sitiado, gatos e cachorros tornaram-se apreciados (NIEUHOF) e os oficiais foram obrigados a apanhar caranguejos nos mangues. Assim também a situação de alimentos no Arraial tornara-se crítica, obrigando o Exército Restaurador a rigorosas medidas de economia.

Barreto de Menezes foi informado da marcha flamenga pelo Cap Francisco Barreiros, que comandava um posto próximo aos Guararapes.

A esquadra holandesa teve diminuída sua capacidade estratégica naval, desde a 1 a Batalha, por falta de aguadas e suprimentos. Isto permitiu que os luso-brasileiros, partindo do Rio de Janeiro, ao comando de Salvador de Sá, cooperassem na libertação de Angola já há sete anos nas mãos da Holanda, e sua principal fonte de braços escravos para o Brasil.

- Dos luso-brasileiros

De posse das informações fornecidas pelas patrulhas que se lançaram sobre o inimigo na noite de 18 para 19, e mais, as conseguidas na manhã de 19, após um estudo de situação em Conselho de Guerra, dão início à tomada de dispositivo.

Ocuparam posições, ao que parece, camuflados nos pântanos situados a SE dos Guararapes e matas abertas situadas ao S e SO de ditos montes.

Nesta situação, acompanham de perto e, atentamente, a todos os movimentos do inimigo.

O grosso de suas forças, ao comando de Fernandes Vieira, é colocado camuflado nos alagados, frente para o Boqueirão, e outro grupamento importante, ao comando de Vidal de Negreiros, é disposto no interior de matas abertas à frente e ao lado do monte em que se ergue a atual Igreja dos Prazeres, onde os holandeses haviam colocados duas peças de artilharia em posição.

Entre os extremos do dispositivo, camuflados nos alagados e matas abertas, foram colocados os terços comandados por Diogo Camarão e Figueiroa. 
Isto é o que é permitido concluir dos relatórios da época e análise da batalha.

É possível que no interior dos alagados existissem várias restingas de mata como a que descreveu Lopes Santiago na $1^{\text {a }}$ Batalha, e que formava o Boqueirão do lado do mar.

\section{INÍCIO DO RETRAIMENTO HOLANDÊS}

Movimentos iniciais

a) Dos holandeses

Após decisão de retraírem para o Recife, tomada pelo Conselho de Guerra Holandês, às três horas da tarde, dão inicio à mudança de dispositivo.

O Regimento de Carpenter, em boa ordem, sai de posição e forma no Boqueirão com a frente para o Recife.

À sua retaguarda, forma a artilharia, protegida pelos flancos, por duas companhias de fuzileiros pertencentes ao Regimento do coronel Brinck.

Esta artilharia reagiria sob o comando do almirante Van Gielissen. Postada no Boqueirão, fez grandes estragos nos nossos até ser silenciada, e Van Gielissen morrer abraçado ao canhão.

A artilharia foi silenciada por tropas de Fernandes Vieira (Lopes Santiago).

Logo a seguir, entra na coluna de marcha o próprio Regimento Brinck.

Assim disposto, este grupamento de marcha iniciou o movimento.

Enquanto isso, os regimentos do Tenente General Von Schkoppe, ao comando do Tenente Coronel Claes e o de Hauthyn, saindo de posição, marchavam sobre o monte Oitizeiro para integrar a coluna de marcha no Boqueirão e constituir a retaguarda em condições de transformar-se em Corpo de Batalha, em caso de ataque inimigo.

Os regimentos de Van der Branden e de Van Elst, em posição no monte da atual Igreja Nossa Senhora dos Prazeres, tinham por missão, tão logo a coluna principal alcançasse distância de segurança, retraírem, retardando o inimigo, sucessivamente, através dos montes Oitizeiro e Telégrafo (atual), até serem acolhidos pela retaguarda da coluna em marcha.

b) Dos luso-brasileiros

De suas posições camufladas nos alagados e matas abertas ao sul dos Guararapes, acompanham atentamente a movimentação holandesa, à procura do momento oportuno para o ataque. O capitão Franca foi encarregado de avisar o momento exato.

Este momento surgiu ao perceberem que a coluna de marcha no Boqueirão já havia abandonado este importante acidente capital, ao mesmo tempo em que os regimentos de Von Schkoppe e de Hauthyn marchavam na crista do monte Oitizeiro, em direção à entrada norte do Boqueirão, para formarem a retaguarda.

\section{ATAQUE LUSO-BRASILEIRO}

Caracterizada a fraqueza do dispositivo inimigo, dois regimentos na defesa e os restantes em deslocamento, o Mestre de Campo Francisco Barreto de Menezes ordenou o 
ataque, que seria conduzido até o final por iniciativa de seus comandantes subordinados, dentro de um quadro de aproveitamento de êxito, seguido de tenaz perseguição.

\section{DESENVOLVIMENTO DA BATALHA}

Ao Mestre de Campo Fernandes Vieira coube, com rapidez ocupar o Boqueirão abandonado e combater a retaguarda do regimento do Cel Brinck, que tentou recuperá-lo. Nesta ocasião, os holandeses eram apoiados pela artilharia de Van Gielissen.

Comandando 800 homens de seu Terço, Fernandes Vieira atacou o inimigo, causando-Ihe pesadas perdas. Lutaria cerca de três horas, na saída do Boqueirão, no local onde hoje situa-se a fábrica Verlon, com os regimentos Brinck e Carpenter, estes apoiados pela artilharia de Gielissen.

Coube a Henrique Dias atacar o Regimento do Tenente General Von Schkoppe, então comandado por Claes. Ao perceber $\mathrm{o}$ ataque, este tentou recuperar 0 Boqueirão abandonado.

Com a impetuosidade do ataque de Henrique Dias, aquele regimento foi obrigado a recuar para o monte Oitizeiro e muitos de seus integrantes começaram a fugir, num prenúncio de grande confusão.

Pressionado com violência e em meio à completa desordem, referido regimento foi recalcado para a entrada norte do Boqueirão, misturando-se aos regimentos de Carpenter e de Brinck.

Coube a Diogo Camarão acometer o Regimento de Hauthyn, em deslocamento sobre o monte Oitizeiro.

O Regimento Hauthyn avançou sobre Diogo Camarão, após largar seus mosquetes e utilizar lanças, procurando assim anular a eficiência das espadas dos patriotas (lanças = alabardas, partazanas).

Diogo Camarão foi tirado da dificuldade em que se encontrava ao ser socorrido pela cavalaria que, provavelmente, Ihe enviou Vidal de Negreiros.

A cavalaria atacou o Regimento Hauthyn e, após anular o efeito das lanças e chuços por eles usados, feriu o Cel Hauthyn, que foi obrigado a retrair sobre o monte Oitizeiro com seu regimento em desordem e em fuga. Assim, acossado por Diogo Camarão, juntou-se aos demais regimentos holandeses na entrada norte do Boqueirão.

A Figueiroa coube atacar o Regimento de Van der Branden, em posição na cota gêmea daquela onde se ergue a atual Igreja dos Prazeres (local do monumento ao Gen Mascarenhas de Morais, erigido em 1971).

Em combinação com esta ação, coube ao Sargento-Mor Antônio Dia Cardoso, o mestre das emboscadas, atacar o Regimento de Van Elst, pela retaguarda, numa emboscada.

Para isto, o bravo Dias Cardoso dispôs de quatro troços do Terço de Fernandes Vieira, do qual era Sargento-Mor. Estas tropas eram compostas presumivelmente de 550 homens, pois Fernandes Vieira ficara com 800 homens. 
O Regimento de Van der Branden, ante a ameaça de cerco, foi obrigado a abandonar sua excelente posição e retrair, na mais completa desordem e confusão, para a garganta norte do Boqueirão.

Perseguido de perto por Vidal de Negreiros, Dias Cardoso e pela cavalaria dos capitães Antônio Silva e Manoel de Araújo, o Regimento de Van Elst foi o que mais baixas sofreu.

Para a garganta norte do Boqueirão, onde hoje (1971) se situa a fábrica Verlon, convergiram na mais completa desordem todos os regimentos holandeses (interpretação do autor).

\section{FINAL DA BATALHA}

$\mathrm{Na}$ entrada norte o Boqueirão, teve fim a batalha. Os holandeses começaram a retirar-se para o Recife, sendo perseguidos por fortes elementos luso-brasileiros até a porta da cidade.

Após três horas de intenso combate em que percorreu grande distância, extenuado pelo grande esforço despendido, o grosso luso-brasileiro entregou-se ao recolhimento dos despojos de guerra abandonados pelos holandeses.

E sobre esta maiúscula vitória, assim escreveu o então Major Souza Júnior, em Do Recôncavo aos Guararapes: "Mais uma vez os patriotas, inferiores em número, mas superiores como combatentes, derrotaram esmagadoramente os soldados de um dos melhores exércitos da Europa, da primeira metade do século XVII".

O testemunho holandês, abaixo transcrito, dará ao leitor uma idéia da violência do ataque e os momentos dramáticos vividos pelos holandeses em debandada geral, perseguidos pelos luso-brasileiros.

\section{CONFUSÃO, DESORDEM, PÂNICO E DESERÇÃO}

"O Cel Claes, que comandava o Regimento do Tenente General (Schkoppe ausente da batalha) e o Cel Hauthyn, ao serem atacados, tentam reconquistar o Boqueirão abandonado".

"Tiveram que recuar para o monte (Oitizeiro) por causa da excessiva força do inimigo, que veio com tanta impetuosidade sobre os nossos, que nossas tropas começaram a fugir e acharam-se logo na maior confusão, a tal ponto que nem palavras nem força puderam retê-las, apesar de todos os esforços dos oficiais e do abaixo assinado...

"As nossas tropas, entregues à desordem, à deserção e à confusão, dispersaram-se aqui e ali, por diversos caminhos em direção ao mato e ao rio...

"Muitos soldados ficaram no caminho por causa da fadiga e esgotamento, e o inimigo, em perseguição ao nosso exército em desordem, encontrando estes desgraçados, matou-os sem quartel...

"A consternação e o pânico entre os nossos foi tão grande que, se o inimigo, ao invés de entregar-se ao saque, como provavelmente o fez, tivesse preferido continuar a perseguição, é indubitavelmente certo que o resto dos nossos se teria deixado matar e 
massacrar sem fazer a mínima resistência, porque fugiam sem voltar os olhos." (o grifo é nosso).

(Relatório de Michael Van Goch, participante da Batalha, feito em 22 fev. 1649, ao Conselho Holandês do Recife)

Este documento é a melhor fonte de reconstituição da $2^{\mathrm{a}}$ Batalha, junto com o depoimento de Lopes Santiago. A sua tradução encontra-se na Biblioteca Nacional do Rio de Janeiro.

Sobre o que foi a batalha, cumpre destacar um trecho de Lopes Santiago:

"Aqui estavam uns clamando e implorando com humildes rogos misericórdia aos vencedores, ali se ouvia a turba dos que pediam bom quartel, em outra parte, em seu idioma dos que mal articulado com as ânsias da morte, queixavam-se de sua adversa fortuna, e muitos entre os mortos, fingindo-se que o estavam, queriam ainda dilatar a breve vida. Finalmente, infinitos precipitados, bem desejavam naquele apertado passo, outras asas de Ícaro e Dédalo, para voarem e não se fazerem pedaços naqueles precipícios e penhascos, correndo copiosa inundação de sangue por todos aqueles montes que era um espetáculo admirável".

\section{PERSEGUIÇÃO}

Sobre o que foi a perseguição aos holandeses, nada melhor que os depoimentos e comentários a seguir.

De Frei Rafael de Jesus, baseado no material de Lopes Santiago, que ele remanejou em o Valeroso Lucideno, segundo J. A. G. de Mello, em Restauradores de Pernambuco.

"Ao inimigo não restou sequer a salvação de uma retirada em ordem. Nem mesmo na fuga tiveram sorte...

"Parece que até o instinto de conservação desordenou-se, pois fugia sem voltar a cara...

"Foi um desastre total e desonroso para as armas da W. I. C....

"Abandonaram armas, bagagens, trem de artilharia munições, bandeiras e feridos. Despojaram-se de tudo que tolhesse a ligeireza da corrida...

"O pior da matança, o mais agravado do desastre, esteve justamente na fuga...

"Os nossos levaram a perseguição até onde puderam, ou até onde lhes permitissem o cansaço, a sede e as sombras da noite".

De Jordão Emerenciano:

"Há muito findara o dia, e a nossa cavalaria continuava a levar a morte e a destruição aos últimos destroços dos soberbos holandeses, que saíram do Recife com tanto estrondo e decisão".

E a perseguição não continuou conforme consta da Relação da Vitória, "cansados estavam todos, uns de fugir e outros de matar e vencer".

E comentaria Von Schkoppe, que comandara na $1^{\text {a }}$ Batalha: "a cavalaria e a infantaria se vieram lançar sobre os nossos regimentos. Causavam tal desordem que nem os 
oficiais, quer superiores, quer inferiores, nem os soldados, puderam resistir e cumprir seu dever. Isto provocou tal consternação entre os nossos, que a pena não poderia descrever (...) e a maior parte de nossas tropas se pôs a fugir, deixando-se matar sem resistência, como crianças".

\section{BAIXAS DE COMBATE}

- Holandesas

Mortos e prisioneiros - 1.044

Feridos - $\underline{500}$

TOTAL 1.544

Este total representou $44 \%$ do efetivo holandês presente na batalha.

Não estão incluídas baixas ocorridas entre os 200 índios e pretos seus aliados, e os 250 marinheiros, o que elevaria bastante esta percentagem, a quase $50 \%$.

Segundo documento existente no Instituto Histórico e Geográfico Brasileiro (Documentos holandeses publicados em Do Recôncavo aos Guararapes, do Maj Souza Júnior), foram as seguintes baixas holandesas por regimentos:

\begin{tabular}{|l|l|l|l|l|}
\hline & Oficiais & Praças & Total & Conclusão do autor \\
\hline Do Ten Gen (Ten Cel Claes & 15 & 135 & 150 & Enfrentou Henrique Dias \\
\hline Carpenter & 22 & 214 & 236 & Enfrentou Fernandes Vieira \\
\hline Brinck & 18 & 133 & 151 & Enfrentou Fernandes Vieira \\
\hline Van der Branden & 22 & 232 & 254 & Enfrentou Figueiroa \\
\hline Van Elst & 16 & 163 & 179 & $\begin{array}{l}\text { Enfrentou Vidal de Negreiros, } \\
\text { Dias Cardoso e Cavalaria }\end{array}$ \\
\hline Hauthyn & 9 & 65 & 74 & Enfrentou Diogo Camarão \\
\hline & $\mathbf{1 0 2}$ & $\mathbf{9 4 2}$ & $\mathbf{1 0 4 4}$ & \\
\hline
\end{tabular}

P. M. Netscher em Holandeses no Brasil fornece as seguintes baixas, com base em relatório que o Conselho do Recife apresentou aos Estados Gerais.

\section{Mortos Feridos}

1 Coronel 2 Capitães

4 Tenentes Coronéis 4 Tenentes

4 Majores 3 Alferes

33 Capitães 6 Sargentos

28 Tenentes 2 Cirurgiões

43 Sargentos 72 Soldados

821 Soldados

927 mortos

89 feridos

Total de baixas - 1.016

E completou:

Não estão incluídos neste número, como mortos, o Vice-Almirante Gielissen e vários de seus marinheiros. 
Dito relatório foi assinado por Schoonenborch, Van Beaumont e Van Goch (membros do Conselho do Recife).

Dos regimentos holandeses que se portaram com maior valor, cumpre destacar o do Cel Hauthyn e, principalmente, o do Cel Van Elst, que suportou todo o peso da luta no monte da atual Igreja Nossa Senhora dos Prazeres.

$O$ ataque de Figueiroa sobre Van der Branden foi arrasador, bem como o de Fernandes Vieira sobre o Regimento Carpenter, a deduzir-se pelas enormes perdas sofridas pelos dois regimentos inimigos.

Nesta batalha, foi morto o coronel Van Brinck, comandante-em-chefe da expedição. Assim, não trouxe, simbolicamente, como prometera, a capa que Von Schkoppe

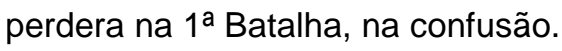

Segundo Netscher, em Holandeses no Brasil, "essas enormes perdas, desproporcionadas para o pequeno número de tropas presentes nesse combate, provam quanto ele foi encarniçado, constituindo, mesmo, o golpe mortal sobre o domínio holandês no Brasil."

- Luso-brasileiras

Mortos - 45

Feridos - $\underline{200}$

245

Presas de guerra feitas pelos luso-brasileiros:

- 5 peças leves de artilharia (toda a artilharia);

- 5 bandeiras;

- quase toda a impedimenta.

FONTE: http://www.ahimtb.org.br/3d.htm (acessado em 13/01/2015) 